\title{
Lacustrine Arcellinida (Testate Lobose Amoebae) as Bioindicators of Arsenic Contamination: A new tool for Environmental Risk Assessment
}

\author{
by
}

Nawaf Ali Nasser

A thesis submitted to the Faculty of Graduate and Postdoctoral
Affairs in partial fulfillment of the requirements for the degree of

Doctor of Philosophy in Earth Sciences

Department of Earth Science

Carleton University

Ottawa, Ontario

October 2019

(C) 2019 Copyright

Nawaf Ali Nasser 


\section{"Taught man that which he knew not"}

(The Glorious Quran; Al-Alaq, 96:5) 


\section{General Abstract}

Gold mining in northern Canada, while profitable, has left a legacy of arsenic (As) contamination, especially in lakes. Arcellinida, lacustrine benthic protozoans, have great As-biomonitoring potential that has yet to be exploited by lake restoration initiatives. This research aims to further develop Arcellinida as a robust tool for monitoring As contamination and remediation efficacy in impacted lakes.

In Chapter 2 a novel Arcellinida sample processing protocol, using chemical deflocculation, was developed to determine optimal approaches for reducing residual organic matter in lake sediments with minimal Arcellinida test degradation. The results revealed that treatment with $5 \%$ potassium hydroxide led to the highest reduction in observed organic content and rate of test damage.

In Chapter 3 results of a study where Arcellinida were examined from 22 nearsurface sediment samples (top $1 \mathrm{~cm}$ ) collected from similar environments in two eastern Canadian lakes was carried out to evaluate faunal assemblages homogeneity in these targeted environments, and to assess the sensitivity of Arcellinida assemblages to interannual environmental variability. The results of this study confirmed the faunal homogeneity of assemblages in limnologically similar environments and demonstrated the sensitivity of Arcellinida assemblages to environmental changes at inter-annual time scales.

In Chapter 4 an inter-lake survey of 91 lakes in the Yellowknife area, Northwest Territories (NT), Canada, was conducted to quantify the response of arcellinidan to gold 
mining-derived As contamination and to statistically determine As-tolerance limits of different Arcellinida species. The results demonstrate the applicability of using Arcellinida to delineate the spatial extent of As contamination and the reliability of using As tolerancelimits-based Arcellinida groups to infer As contamination levels in lake sediments.

In Chapter 5 the arcellinidan response to intra-lake changes in As contamination, derived from two former gold mines, was investigated in 40 near-surface sediment samples from two lakes in the low Arctic, central NT (Tundra Mine) and in a boreal setting, southern NT (Giant Mine). It was demonstrated that Arcellinida assemblages responded differently to the impact of As, likely due to different As mineralization in each lake, which was in turn a by-product of employing different ore-processing techniques at the former gold mines. 


\section{Acknowledgments}

It is a pleasure to finally express my gratitude to all the people that have, directly or indirectly, contributed to the success of this project. First and foremost, I owe my deepest gratitude to my supervisor Dr. R. Tim Patterson for accepting me as his Ph.D. student, offering countless opportunities to grow as a researcher and as a person, sharing his wealth of knowledge in the fields of micropaleontology and environmental geology, and for being an outstanding mentor. I thank him greatly for his continuous support and guidance throughout the project and for his constant drive to publish and share my results. Similarly, it is difficult to see this project coming together the way it did without the admirable mentorship of my co-supervisor, Dr. Jennifer Galloway. I thank her for always pushing me to exceed my limits and achieve excellence. My thanks are also extended to the members of my $\mathrm{Ph}$.D. defense committee for taking the time out of their busy schedules to evaluate the dissertation and attend the thesis defense.

Funding for this research project was provided by a Polar Knowledge Canada grant awarded to JMG and RTP. The project was also funded by an NSERC Discovery Grant, Carleton University Development grants, NSERC Strategic Project Grant, and a Cumulative Impact Monitoring Program grant awarded to RTP. This project was also supported by the Geological Survey of Canada, Environmental Geoscience Program, Metal Mining Project, Northern Baselines Activity led by JMG. Funding was also provided by and Northern Scientific Training Program (NSTP), Loeblich and Tappan Student Research Award, and Geological Society of America Research Grant (GSA) awarded to NAN. Additional direct and in-kind funding was provided by the Northwest Territories 
Geological Survey, Natural Resources Canada Polar Continental Shelf Program, TerraX Minerals, Seabridge Gold Inc., and Crown Indigenous and Northern Affairs Canada (CIRNAC) - Tundra Mine Remediation Project.

Countless other people helped me along the way. I would like to thank Clare Miller (Queen's University, Ontario) for her assistance with sample collection at Hambone Lake in 2016. My thanks are extended to Crown Indigenous Relations and Northern Affairs Canada (CIRNAC), Delta Engineering, and Nahanni Construction for their hospitality and kind support during the summer field season of 2016 at the former Tundra Mine site. I thank Michael Palmer and the Northwest Territories Cumulative Impact Monitoring program (CIMP) program for field assistance and providing the helicopter time to support the field program. Special thanks to Dr. Hamed Sanei, Aarhus University, Denmark, for kindly providing the Rock Eval pyrolysis analysis and assistance with understanding those results. I would also like to thank the staff and students of the Earth Sciences Department at Carleton University for their continuous support. I am grateful to Elizabeth Anderson for her constructive comments on the papers presented in this project. I am indebted to past and present members of the Patterson Research Group (PRG) for their encouragement and support. I would like to particularly thank Braden Gregory (soon to be Dr. Gregory) with whom I've shared this great academic journey and countless hours of research discussions.

I am thankful to Dr. Arafat Al Shuaibi, professor of Earth Sciences at Kuwait University, for his support and encouragement. A warm thank you to Dr. Nasser Al Qattan, for his continuous motivation. I am grateful to Mohammad Al Kandari for his constant encouragement, support, and for rekindling my love for fiction reading and writing! I want to thank my Al Qadesia friends for always being a stout pillar of support. 
Finally, I cannot begin to express my gratitude to my family for their unconditional love and support throughout this journey. To my parents, your support, love, and faith in me kept me going all these years. I hope that I have made you proud. To my siblings, thank you for always being there for me and for always finding a way to make me smile. 


\section{Preface}

This is an integrated thesis consisting of four articles published or submitted to peer-reviewed scientific journals. Each article has been modified to comply with Carleton University guidelines. Table and figure numbers have been standardized and updated to be consistent within the thesis:

\section{Chapter 2: Behind the organic veil: assessing the impact of} chemical deflocculation on organic content reduction and lacustrine Arcellinida (testate amoebae) analysis. Chapter 2 describes a novel Arcellinida sample preparation protocol based on chemical deflocculation for the reduction of organic matter in lake sediment samples. This chapter was published in Microbial Ecology (DOI 10.1007/s00248-019-01429-0), with an author list of Nawaf A. Nasser, Braden R.B. Gregory, Riley E. Steele, R. Timothy Patterson, Jennifer M. Galloway. Near-surface sediment samples were collected by NAN. The experimental design for the study was conceived by NAN, BRBG, and RES. Sample processing was carried out by NAN, BRBG, and RES. Micropaleontological analysis, statistical analysis, and results interpretation was completed by NAN. The manuscript was written by NAN under the supervision of RTP and JMG with feedback from BRBG and RES. Drafting of supporting figures, tables, and supplementary materials was completed by NAN. 
Recommended citation: Nasser NA, Gregory BR, Steele RE, Patterson RT, Galloway JM. 2019. Behind the Organic Veil: Assessing the Impact of Chemical Deflocculation on Organic Content Reduction and Lacustrine Arcellinida (Testate Amoebae) Analysis. Microbial ecology. 1-6. DOI 10.1007/s00248-019-01429-0

\section{Chapter 3: Inter-Annual Arcellinida (testate lobose amoebae)} Assemblage Dynamics within Lacustrine Environments. Chapter 3 is on the assessment of inter-annual changes in Arcellinida assemblages and the homogeneity of these assemblages in relatively similar lacustrine environments in near-surface sediment samples $(n=22)$ from two lakes in eastern Canadian lakes (Lac du Castor Blanc, SW Quebec; Oromocto Lake, SW New Brunswick). This chapter was published in Limnologica (v. 76: 60-71; DOI 10.1016/j.limno.2019.03.006), with an author list of Nawaf A. Nasser, Jaclyn Cullen, Calder W. Patterson, R. Timothy Patterson, Helen M. Roe, and Jennifer M. Galloway. Near-surface sediment samples were collected by RTP, HMR, and CWP. The study was conceived by RTP, JMG, and NAN. Sample processing was carried out by NAN and JC. Micropaleontological analysis was carried out by JC. Statistical analysis and results interpretation was completed by NAN. The manuscript was written by NAN under the supervision of RTP and JMG with feedback from JC, CWP, and HMR. Drafting of supporting figures, tables, and supplementary materials was completed by NAN. 
Recommended citation: Nasser NA, Cullen J, Patterson CW, Patterson RT, Roe HM, Galloway JM. 2019. Inter-annual Arcellinida (testate lobose amoebae) assemblage dynamics within lacustrine environments. Limnologica. 76:60-71.

DOI 10.1016/j.limno.2019.03.006

\section{Chapter 4: Use of Arcellinida (testate lobose amoebae) Arsenic} tolerance limits as novel tool for biomonitoring Arsenic contamination in lakes. Chapter 4 is an assessment of the arsenic tolerance limits of Arcellinida species and strains in 93 near-surface sediment samples from lakes in the Yellowknife area, Northwest Territories (NT), Canada. This chapter has been submitted as a manuscript to Ecological Indicators (submission date: 12/7/2019), with an author list of Nawaf A. Nasser, R. Timothy Patterson, Helen M. Roe, Jennifer M. Galloway, Hendrik Falck, and Hamed Sanei. Near-surface sediment samples were collected by NAN, RTP, JMG, and HMR. The study design was conceived by RTP and JMG. Sample processing, micropaleontological analysis, statistical analysis, and results interpretation was completed by NAN. Rock Eval pyrolysis data was provided by HS. The manuscript was written by NAN under the supervision of RTP and JMG with feedback from HMR, HF, and HS. Drafting of supporting figures, tables, and supplementary materials was completed by NAN. 
4. Chapter 5: Intra-lake response of Arcellinida (testate lobose amoebae) to gold mining-derived arsenic contamination in northern Canada: Implications for environmental monitoring. Chapter 5 is an investigation of the response of Arcellinida populations to intra-lake variability in levels of arsenic contamination, derived from the operations of the historic Giant and Tundra mines, in two lakes in the central NT (Frame Lake and Hambone Lake). This manuscript is currently under development for submission to PeerJ with an author list of Nawaf A. Nasser, R. Timothy Patterson, Jennifer M. Galloway and Hendrik Falck, and Hamed Sanei. The study design was conceived by RTP, JMG, and NAN. Near-surface sediment samples were collected by NAN. Sample processing, micropaleontological analysis, statistical analysis, and results interpretation was completed by NAN. The manuscript was written by NAN under the supervision of RTP and JMG with feedback from HF. Drafting of supporting figures, tables, and supplementary materials was completed by NAN.

The thesis supervisor (Dr. R. Timothy Patterson) and co-supervisor (Dr. Jennifer M, Galloway) acknowledges the above information as accurate. 


\section{Table of Contents}

General Abstract...................................................................iii

Acknowledgments .......................................................................v v

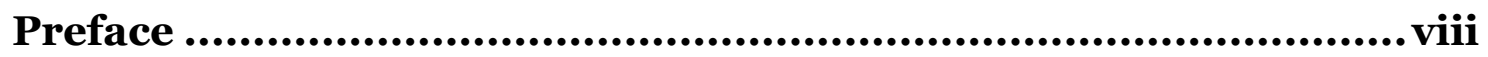

Table of Contents................................................................xii

List of Figures......................................................................... xvi

List of Tables .............................................................. xxix

List of Plates ...................................................................... xxx

Chapter 1: Introduction ......................................................... 1

1.1 Research background and motivation....................................................... 1

1.1.1 Shelled Bioindicators as Environmental Proxies................................... 4

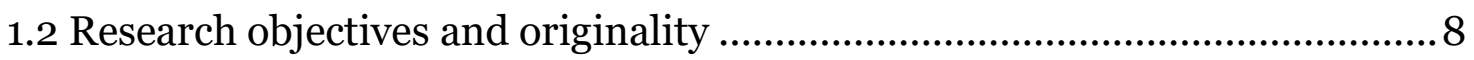

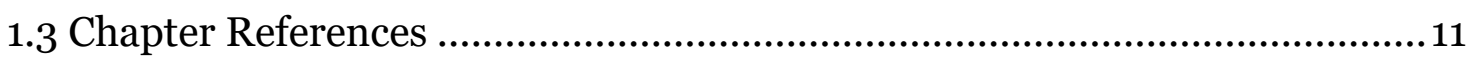

Chapter 2: Behind the organic veil: assessing the impact of chemical deflocculation on organic content reduction and lacustrine Arcellinida (testate amoebae) analysis ...................................... 22

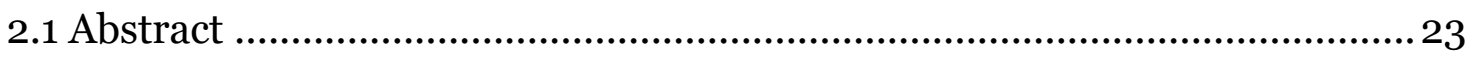

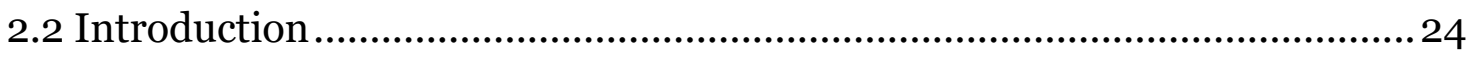

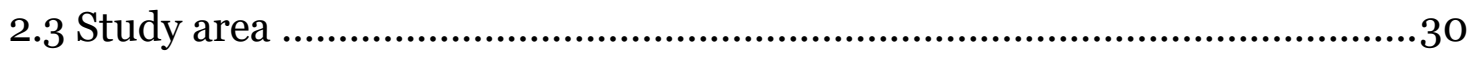

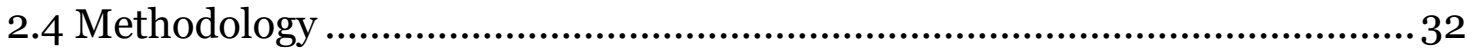

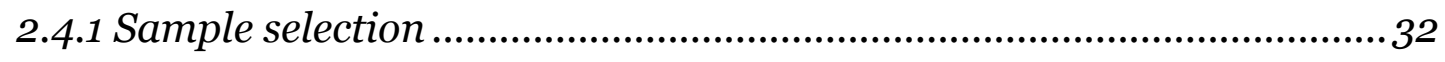

2.4.2 Arcellinida Taxonomy ....................................................................... 32

2.4.3 Chemical treatment methods .................................................................33

2.4.4 Statistical Methods ............................................................................ 41

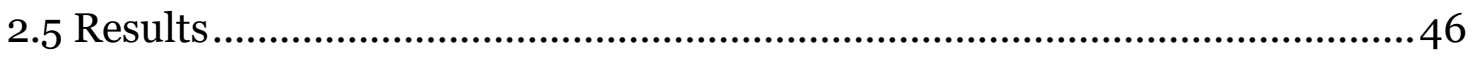

2.5.1 Chemical methods testing …...................................................................46

2.5.1.1 Stage 1 - Determining optimal concentrations .................................46

2.5.1.2 Stage 2 - Determining optimal exposure times ................................ 47

2.5.1.3 Stage 3 - Comparison of treated and untreated sample counts ...48 
2.5.2 Identified Arcellinida assemblages .............................................................49

2.5.2.1 Moderate diversity assemblage (MD) ........................................... 51

2.5.2.2 Difflugia elegans assemblage (DE) .............................................. 52

2.5.2.3 Centropyxis aculeata assemblage (CA) ........................................... 54

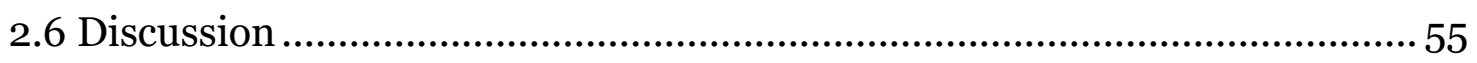

2.6.1 Reduction of organic content using chemical treatment........................55

2.6.2 Damage to Arcellinida tests ................................................................... 56

2.6.3 Arcellinidan test retention and faunal composition...............................58

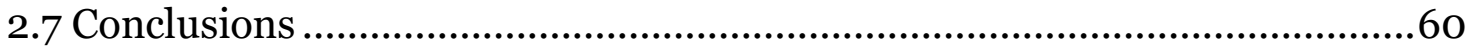

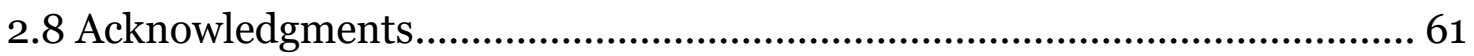

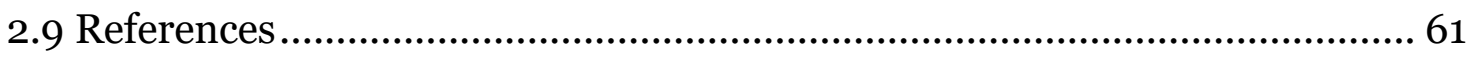

\section{Chapter 3: Inter-Annual Arcellinida (testate lobose amoebae)} Assemblage Dynamics within Lacustrine Environments.............. 67

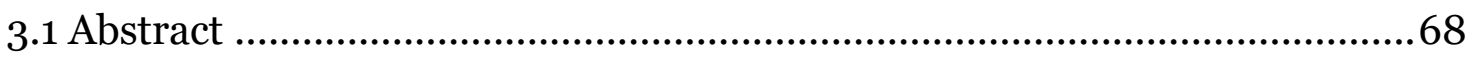

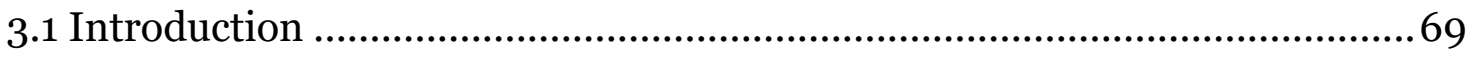

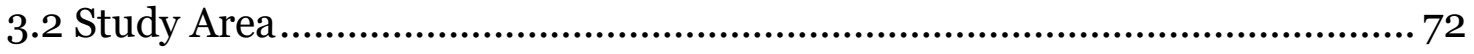

3.2.1 Lac du Castor Blanc .............................................................................. 72

3.2.2 Oromocto Lake................................................................................. 74

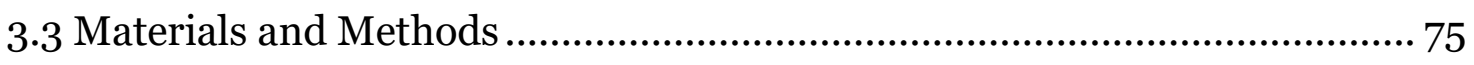

3.3.1 Sampling Design and Filed Work ........................................................ 75

3.3.2 Laboratory Analyses .........................................................................76

3.3.3 Statistical Analyses ........................................................................... 78

3.3.3.1 Data screening and preparation...................................................... 84

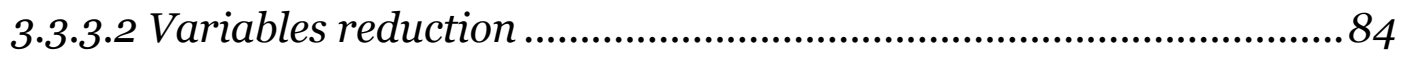

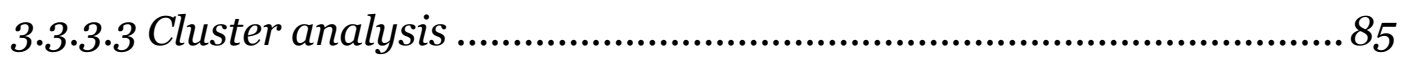

3.3.3.4 Detrended Correspondence Analysis (DCA) .................................. 85

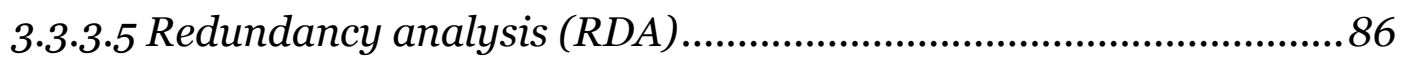

3.3.3.6 Bray-Curtis Dissimilarity Matrix (BCDM) ....................................86

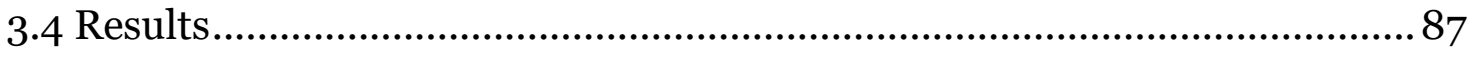

3.4.1 Lake Parameters ........................................................................... 87

3.4.2 Textural and organic matter characteristics ....................................... 87

3.4.3 Identified Arcellinida Assemblages and Primary Controls ..................88 
3.4.4 Description of Identified Arcellinida Assemblages ................................ 95

3.4.4.1 Lac du Castor Blanc Assemblage 'LCA' $(n=6)$.................................. 95

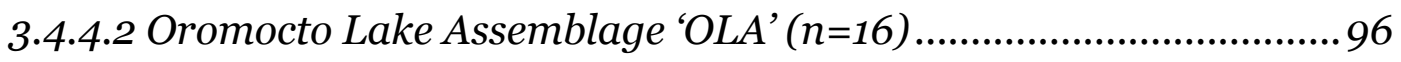

3.4.4.3 Oromocto Lake 201O Sub-Assemblage 'OL1O' $(n=8)$...................... 97

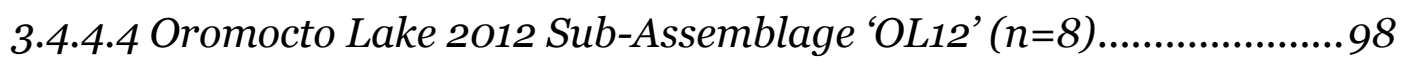

3.5 Discussion ................................................................................................. 99

3.5.1 Arcellinida assemblage homogeneity ................................................99

3.5.2 Controls over Arcellinida assemblage composition .............................100

3.5.3 Arcellinida assemblage dynamics in response to inter-annual environmental variability .............................................................................103

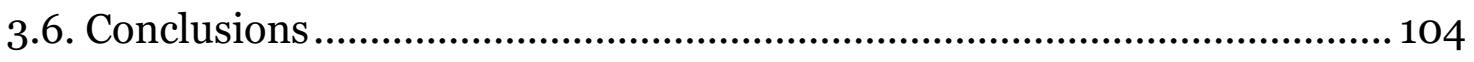

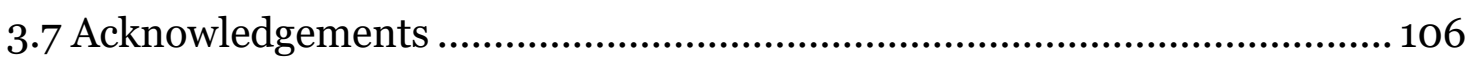

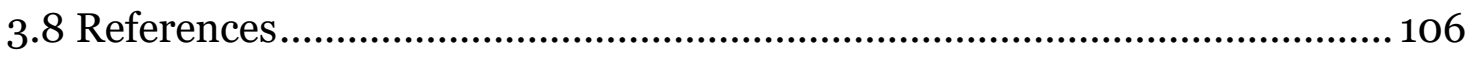

Chapter 4: Determining Arcellinida (testate lobose amoeabae) Arsenic tolerance limits: A novel tool for biomonitoring Arsenic contamination in impacted lakes ............................................119

4.1 Abstract Graphic .................................................................................... 120

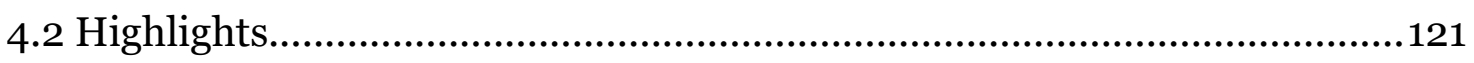

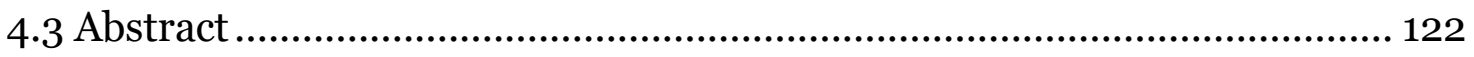

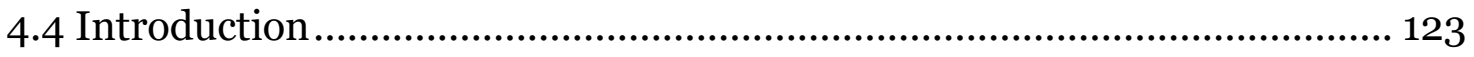

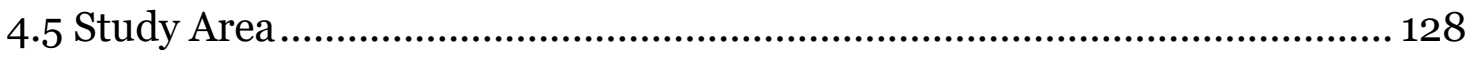

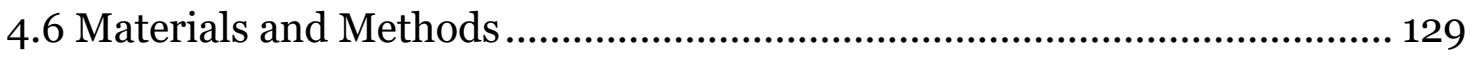

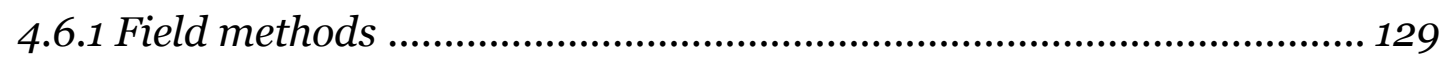

4.6.2 Laboratory methods ........................................................................ 130

4.6.3 Data screening, variables reduction ..................................................... 133

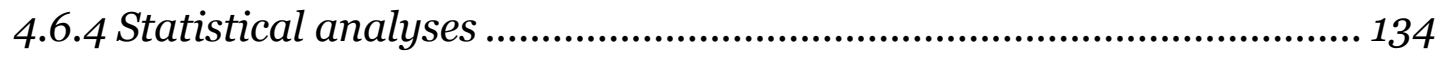

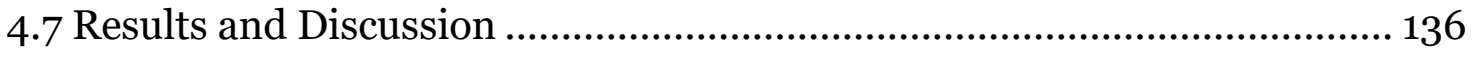

4.7.1 Spatial Distribution of As..................................................................... 136

4.7.2 Arcellinida Assemblages ......................................................................141

4.7.3 Controls over the Distribution of Arcellinida ...................................... 145

4.7.4 Interaction between Arcellinida, As and $S 1$....................................... 150

4.7.5 Tolerance of Arcellinida Taxa to As ......................................................151 
4.7.6 Paleoenvironmental Assessment Tool...................................................155

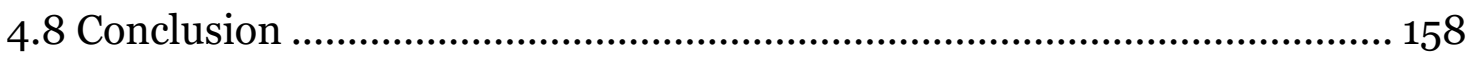

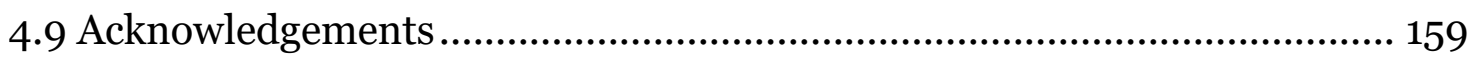

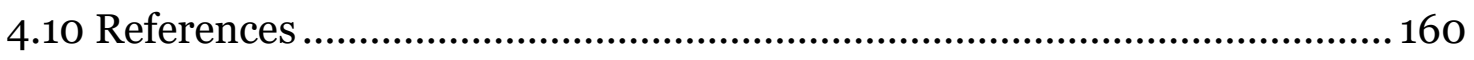

Chapter 5: Intra-lake response of Arcellinida (testate lobose amoebae) to gold mining-induced arsenic contamination in northern Canada: Implications for environmental monitoring ...174

5.1 Abstract.................................................................................................175

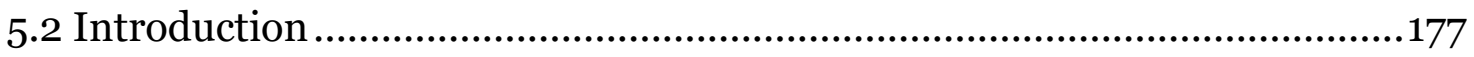

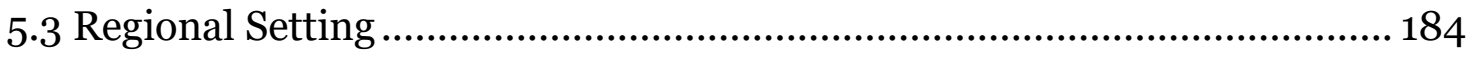

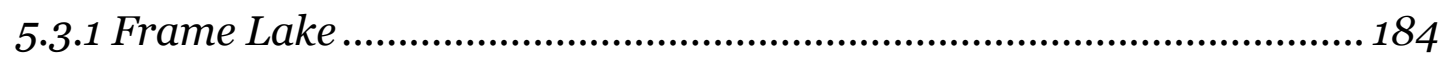

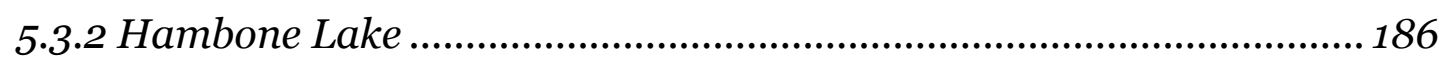

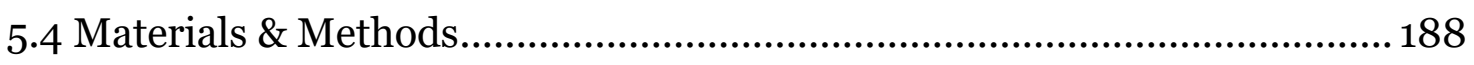

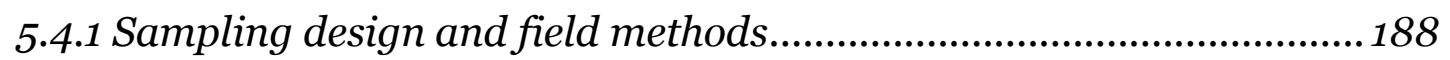

5.4.2 Laboratory methods .............................................................................188

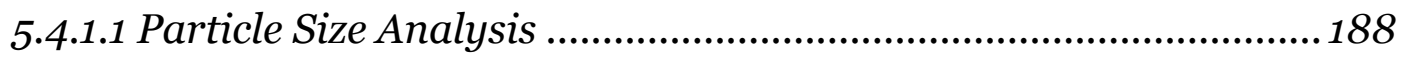

5.4.1.2 Geochemical analysis ..................................................................... 189

5.4.1.3 Olsen phosphorus (OP) extraction ……………………................ 190

5.4.1.4 Loss-on-ignition ..............................................................................190

5.4.1.5 Micropaleontological analysis ......................................................191

5.4.3 Statistical analysis ............................................................................ 192

5.4.3.1 Data screening, variables selection, and multivariate statistics. 198

5.5 Results ..................................................................................................203

5.5.1 Intra-Lake distribution of As ...............................................................203

5.5.2 Description of identified Arcellinida assemblages ...............................206

5.5.2.1 Extreme As Contamination Assemblage (EAC)............................207

5.5.2.2 High Calcium Assemblage (HC) ................................................. 208

5.5.2.3 Moderate As Contamination Assemblage (MAC) .......................... 210

5.5.2.4 High Nutrients Assemblage (HN) ...................................................211

5.5.2.5 High Diversity Assemblage (HD) ................................................ 213

5.5.2.6 Centropyxis aculeata Assemblage (CA)......................................... 214

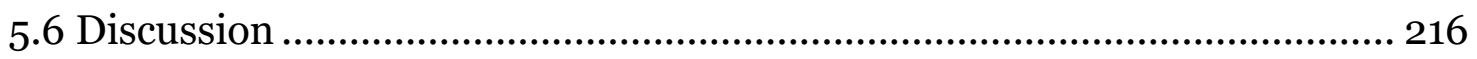


5.6.1 Controls over the Intra-lake Arcellinida distribution........................... 216

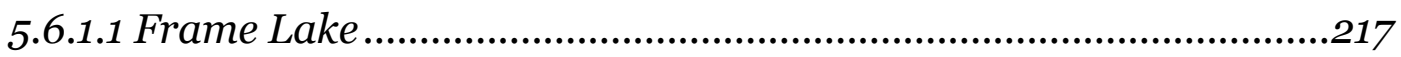

5.6.1.2 Hambone Lake ..........................................................................220

5.6.2 Consistency of the arcellinidan response to As contamination ..........222

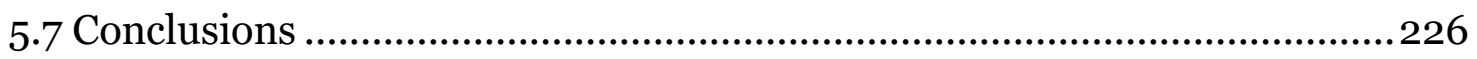

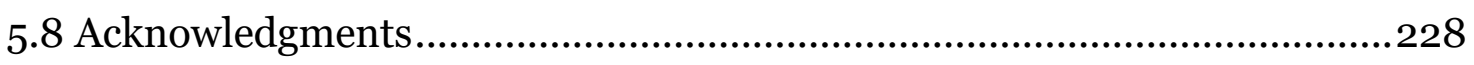

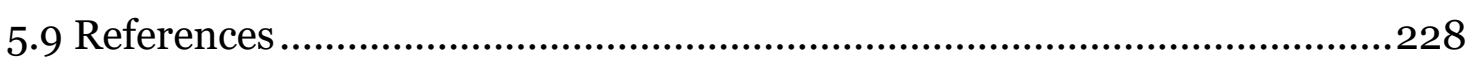

Chapter 6: Conclusions.............................................................. 247

6.1 A novel Arcellinida sample processing protocol........................................247

6.2 Arcellinida assemblages homogeneity and inter-annual dynamic ............249

6.3 Quantifying the relationship between Arcellinida and As ........................250

6.3.1 Inter-lake spatial survey ..............................................................250

6.3.2 Intra-lake spatial survey ................................................................ 251

6.4 Potential Areas of Future Work.............................................................253

Appendices ............................................................................ 259

7.1 Appendix A - Chapter 2 Materails .........................................................259

7.2 Appendix B - Chapter 3 Materails .............................................................. 265

7.3 Appendix C - Chapter 4 Materails ..............................................................296

7.4 Appendix D - Chapter 5 Materails............................................................. 361

7.5 Appendix E - Arcellinida Systematics ...................................................... 372 


\section{List of Figures}

Figure 2. 1: A) Map of Canada showing the study location in the Northwest Territories, Canada (dark blue) as a yellow circle. B) A map showing sampling sites (green and yellow circles) within $30 \mathrm{~km}$ radius around the City of Yellowknife. Lakes sampled in this study $(\mathrm{n}=3)$ are represented as yellow circles. 31

Figure 2. 2: Schematic view of sample preparation methods used in this study. A) Standard Arcellinida sample preparation protocol. A sediment sample (often three $\left.\mathrm{cm}^{3}\right)$ is sieved through coarse ( $297 \mu \mathrm{m} ; 30$ seconds) and fine (38 $\mu \mathrm{m}$; two minutes) sieves and split prior to arcellinidan analysis. B) First chemical methods testing stage, in which the impact of chemical treatment on organic content reduction was assessed. Three sediment subsamples (three $\mathrm{cm}^{3}$ each), from each YK sample, were split into six aliquots $(n=54)$. Five aliquots were treated with different concentrations of a chemical deflocculant for three hours before sieving. A single aliquot was processed following the standard sample preparation protocol (control subsample). C) Second chemical methods testing stage, in which optimal treatment duration was determined and impact on Arcellinida tests was assessed. Three sediment subsamples (one $\mathrm{cm}^{3}$ each), from each YK sample, were split into six aliquots $(n=54)$. Aliquots were treated with one selected concentration of each chemical deflocculant for different treatment durations prior to sieving. D) Third chemical methods testing stage. Three sediment subsamples (one $\mathrm{cm}^{3}$ subsample per YK sample) were split into six aliquots $(n=18)$. Three aliquots were treated 
with the optimal chemical method and concentration for three hours, and three were processed following the standard sample preparation protocol. Treated and control sub-samples were sieved prior to arcellinidan analysis............................. 36

Figure 2. 3: Photomicrographs showing the level of organic content reduction in chemically treated, with different concentrations of soda ash, $\mathrm{KOH}$, and Calgon, and control YK2O sub-samples. 38

Figure 2. 4: Photomicrographs showing the level of organic content reduction in chemically treated, with different concentrations of soda ash, $\mathrm{KOH}$, and Calgon, and control YK25 sub-samples.

Figure 2. 5: Photomicrographs showing the level of organic content reduction in chemically treated, with different concentrations of soda ash, $\mathrm{KOH}$, and Calgon, and control YK57 sub-samples. 40

Figure 2. 6: Q-mode cluster analysis dendrogram showing three identified Arcellinida assemblages: 1) Moderate Diversity Assemblage (MDA); 2) Centropyxis aculeata Assemblage (CPA); and, 3) Difflugia elegans Assemblage (DEA). Six faunal sub-assemblages are also indicated with the colored rectangles. The statistical significance of each assemblage and sub-assemblage was indicated by the results of PVClust (red numbers; $p$-value $<0.05$ ) 
Figure 2. 7: A histogram plot showing the total number of Arcellinida tests (xaxis) retained in all $5 \% \mathrm{KOH}$ treated and control sub-samples (y-axis). The different colours reflect the identified assemblages and sub-assemblages. MDA Moderate Diversity Assemblage; CAA - Centropyxis aculeata Assemblage; DEA - Difflugia elegans Assemblage. 50

Figure 3. 1: Map of the study areas. A) map of Canada showing the sampled lakes (yellow circles) in Quebec (light blue highlight) and New Brunswick (Light red highlight). B) A map showing the sampled sites (yellow circles) in Gracefield Camp Cove (red square), Lac du Castor Blanc, Quebec, Canada. C) A map showing the sampled sites (yellow circles) in Wightman Cove (red square), Oromocto Lake, New Brunswick, Canada. 73

Figure 3. 2: Arcellinina from Lac du Castor Blanc and Oromocto Lake. 1 Arcella vulgaris (Ehrenberg 1830). 2-3 Centropyxis aculeata (Ehrenberg 1832) stain "aculeata". 4-5 Centropyxis aculeata (Ehrenberg 1832) stain "discoides". 6-7 Centropyxis constricta (Ehrenberg 1843) stain "aerophila". 8-10 Centropyxis constricta (Ehrenberg 1843) stain "constricta". 11 Centropyxis constricta (Ehrenberg 1843) stain "spinosa". 12 Cucurbitella tricuspis (Carter 1956). 13-15 Mediolus corona (Wallich 1986). 16-17 Pontigulasia compressa (Carter 1864). 1819 Lagenodifflugia vas (Leidy 1874). 20 Lesquereusia spiralis (Ehrenberg 1840). 
Figure 3. 3: Arcellinina from Lac du Castor Blanc and Oromocto Lake.1 Heleopera sphagni (Leidy 1874). 2 Difflugia elegans (Penard 1890). 3 Difflugia bicornis (Penard, 1890). 4 Difflugia urceolata Carter 1864 strain "urceolata". 5 Difflugia urens (Patterson, MacKinnon, Scott, and Medioli 1985). 6 Difflugia glans (Penard 1902) strain "glans". 7 Difflugia glans (Penard 1902) strain “distenda”. 8 Difflugia glans (Penard 1902) strain "magna”. 9-10 Difflugia oblonga (Ehrenberg 1832) strain "oblonga”. 11-12 Difflugia oblonga (Ehrenberg 1832) strain "spinosa". 13-14 Difflugia oblonga (Ehrenberg 1832) strain "tenuis". 15 Difflugia oblonga (Ehrenberg, 1832) strain "lanceolata". 17 Difflugia protaeiformis (Lamarck 1816) strain "acuminata". 18 Difflugia protaeiformis (Lamarck 1816) strain "claviformis". 19 Difflugia protaeiformis (Lamarck 1816) strain "curvicaulis". 20 Difflugia protaeiformis (Lamarck 1816) strain "sculpellum". .82

Figure 3. 4: Combined Q-mode and R-mode cluster heatmap for the 22 samples and 33 statistically significant species and strains. Two faunal assemblages, and two sub-assemblages, are indicated. The colored squares (gradient of red) reflect the relative abundances of the Arcellinida species and strains. The statistical significance of the identified assemblages, as determined by using PVClust values, is displayed next to the assemblages (red number). $\mathrm{AV}=$ Arcella vulgaris; $\mathrm{CAA}=$ Centropyxis aculeata "aculeata", $\mathrm{CAD}=$ Centropyxis aculeata "discoides", CCA = $i$ "aerophila", $\mathrm{CCC}=$ Centropyxis constricta "constricta", $\mathrm{CCS}=$ Centropyxis constricta "spinosa", CT= Cucurbitella tricuspis, $\mathrm{CK}=$ Cyclopyxis kahli, DB = 
Difflugia bidens, $\mathrm{MC}=$ Mediolus corona, DGG = Difflugia glans "glans", DGM = Difflugia glans "magna", DGD = Difflugia glans "distenda" , DOB = Difflugia oblonga "bryophila", DOL = Difflugia oblonga "lanceolata", DOL = Difflugia oblonga "linearis", DOO = Difflugia oblonga "oblonga", DOS = Difflugia oblonga "spinosa", DOT = Difflugia oblonga "tenuis", DP = Difflugia protaeiformis, DA = Difflugia acuminata, DCL = Difflugia claviformis; DCUR = Difflugia curvicaulis; DSC $=$ Difflugia scalpellum $;$ DAI $=$ Difflugia acuminate "immanata; DAB $=$ Difflugia acuminate "bicornis", DUU = Difflugia urceolata "urceolata", DUE = Difflugia urceolata "elongata", DU = Difflugia urens, DE = Difflugia elegans, LV = Lagenodifflugia vas, $\mathrm{LS}=$ Lesquereusia spiralis, $\mathrm{PC}=$ Pontigulasia compressa .

Figure 3. 5: Detrended correspondence analysis (DCA) showing the results for the two Arcellinida assemblages and two sub-assemblages in multidimensional space. 92

Figure 3. 6: (A) Redundancy Analysis (RDA) species-environment-sample triplot for the 22 surface-sediment samples that yielded statistically significant proportions of 33 Arcellinida taxa. The tri-plot also shows the assemblages and sub-assemblages and their relationship with the measured variables. (B) Partial Redundancy Analysis (pRDA) with variance partitioning test showing the percentage variance in the Arcellinida data set that is explained by the measured variables. $\mathrm{AV}=$ Arcella vulgaris $; \mathrm{CAA}=$ Centropyxis aculeata "aculeata", $\mathrm{CAD}=$ 
Centropyxis aculeata "discoides", CCA = Centropyxis constricta "aerophila", CCC = Centropyxis constricta "constricta", $\mathrm{CCS}=$ Centropyxis constricta "spinosa", $\mathrm{CT}=$ Cucurbitella tricuspis, $\mathrm{CK}=$ Cyclopyxis kahli, $\mathrm{DB}=$ Difflugia bidens, $\mathrm{MC}=$ Mediolus corona, DGG = Difflugia glans "glans", DGM = Difflugia glans "magna", DGD = Difflugia glans "distenda" , DOB = Difflugia oblonga "bryophila", DOL = Difflugia oblonga "lanceolata", DOL = Difflugia oblonga "linearis", DOO = Difflugia oblonga "oblonga", DOS = Difflugia oblonga "spinosa", DOT = Difflugia oblonga "tenuis", DP = Difflugia protaeiformis, DA = Difflugia acuminata, DCL = Difflugia claviformis; DCUR = Difflugia curvicaulis; DSC = Difflugia scalpellum; DAI = Difflugia acuminate "immanata; DAB = Difflugia acuminate "bicornis", DUU = Difflugia urceolata "urceolata", DUE = Difflugia urceolata "elongata", DU = Difflugia urens, DE = Difflugia elegans, LV = Lagenodifflugia vas, $\mathrm{LS}=$ Lesquereusia spiralis, $\mathrm{PC}=$ Pontigulasia compressa. 94

Figure 4. 1: Map of sampling sites showing the locations of the 93 near-surface sediment samples examined in the study (colored circles). The color-coding of the circles reflects the spatial distribution of As in the Yellowknife area, which is divided into three categories: high (red circles), moderate (yellow circles), and low (green circles). The dashed circle represents the outer limits of the Giant Mine zone of immediate Airborne As contamination impact. 
Figure 4. 2: Scanning electron microscope of selected arcellininid tests from the study lakes. For more specimen information see SA 7. 1 Arcella vulgaris (Ehrenberg 1830). 2-3 Centropyxis aculeata (Ehrenberg 1832) stain "aculeata". 45 Centropyxis aculeata (Ehrenberg 1832) stain "discoides". 6-7 Centropyxis constricta (Ehrenberg 1843) stain "aerophila". 8-10 Centropyxis constricta (Ehrenberg 1843) stain "constricta”. 11 Centropyxis constricta (Ehrenberg 1843) stain "spinosa". 12-17 Conicocassis pontigulasiformis (Beyens, Chardez and De Bock 1986). 18-21 Cucurbitella tricuspis (Carter 1956)....................................... 138

Figure 4. 3: Scanning electron microscope of selected Arcellinidan tests from the study lakes. 1 Mediolus corona (Patterson, and Wallich 1986) specimen from sample BC 51. 2 Heleopera sphagni (Leidy 1874) specimen from sample BC 9. 3 Lesquereusia spiralis (Ehrenberg 1840) specimen from sample $\mathrm{BC}_{52 .} 4$ Pontigulasia compressa (Carter 1864) specimen from sample BC 30. 5 Lagenodifflugia vas (Leidy 1874) specimen from sample BC 9. 6. Difflugia bidens (Penard 1902) from sample BC 6. 7-8 Difflugia elegans Penard 1890. 9 Difflugia urens (Patterson, MacKinnon, Scott, and Medioli 1985) specimen from sample BC 27. 10 Difflugia glans (Penard 1902) strain "glans" specimen from sample BC 52. 11 Difflugia glans (Penard 1902) strain “distenda”. 12-13 Difflugia oblonga (Ehrenberg 1832) strain "oblonga”. 14 Difflugia oblonga (Ehrenberg 1832). 15 Difflugia oblonga (Ehrenberg 1832) strain "tenuis". 16 Difflugia protaeiformis Lamark 1816 strain “protaeiformis”. 17 Difflugia protaeiformis Lamark 1816 strain 
"acuminata". 18 Difflugia protaeiformis Lamark 1816 strain "claviformis". 19 Difflugia curvicaulis Penard 1899. 20 Difflugia scalpellum Penard 1899. 140

Figure 4. 4: Combined Q-mode and R-mode cluster dendrogram for the 84 samples and 25 statistically significant species and strains. Five faunal assemblages are indicated 142

Figure 4. 5: None-Metric Multidimensional Scaling (NMDS) bi-plot. AV Arcella vulgaris, CAA - Centropyxis aculeata "aculeata", CAD - Centropyxis aculeata "discoides", CCA - Centropyxis constricta "aerophila", CCC Centropyxis constricta "constricta", CCS - Centropyxis constricta "spinosa", CP Conicocassis pontigulasiformis, CT - Cucurbitella tricuspis, MC - Mediolus corona, DB - Difflugia bidens, DOO - Difflugia oblonga "oblonga”, DOS Difflugia oblonga "spinosa", DOT - Difflugia oblonga "tenuis", DGG - Difflugia glans "glans", DGD - Difflugia glans "distenda", DU - Difflugia urens, DE Difflugia elegans, DPP - Difflugia protaeiformis "protaeiformis", DPAC Difflugia protaeiformis "acuminata", DPCl - Difflugia protaeiformis “claviformis", DCUR - Difflugia protaeiformis "curvicaulis", DPSC - Difflugia protaeiformis "scalpellum", LS - Lesquereusia spiralis, LV - Lagenodifflugia vas, PC - Pontigulasia compress. 144 
Figure 4. 6: Redundancy Analysis (RDA) species-environment-sample tri-plots for the 84 sediment-water-interface samples that yielded statistically significant arcellinidan populations and had no missing values. The five identified Arcellinida assemblages are: 1) the high As contamination assemblage (red square); 2) As contamination assemblage (light blue diamond); 3) Centropyxis aculeata assemblage (purple pentagon); 4) transitional assemblage (blue triangle); and 5) healthy assemblage (green circle). 146

Figure 4. 7: Results of the Weighted Average Tolerance and Optima Analysis (WATO) on the 25 statistically significant arcellinidan taxa. 153

Figure 4. 8: The correlation between Arcellinida As tolerance group and As concentrations of 30 freeze core samples from Frame Lake. The strength of the correlation is represented by three colored symbols, with the green square representing a strong correlation, the orange triangle representing a mismatch (weak correlation) due to the influence of As remobilization, and the red circle representing a mismatch due to the influence of other confounding variables (modified after Gavel et al., 2018).

Figure 5. 1: Map of the study area and sampled lakes. (A) a map showing the study area in the central Northwest Territories, Canada and the locations of the historic Giant (black and yellow icon) and Tundra mines (red and yellow icon). (B) a map showing Frame Lake and the location of the 25 sampling stations. (C) a map showing Hambone Lake and the location of the 15 sampling stations. The colour- 
coded and graduated circles reflect the As concentration at each sampling station.

Figure 5. 2: Scanning electron microscope plate of Arcellinida specimens from Frame Lake and Hambone Lake. 1-2 Centropyxis aculeata (Ehrenberg 1832) stain "aculeata". 3-4 Centropyxis aculeata (Ehrenberg 1832) stain "discoides". 5-6 Centropyxis constricta (Ehrenberg 1843) stain "aerophila". 7-8 Centropyxis constricta (Ehrenberg 1843) stain "constricta". 9-10 Cucurbitella tricuspis (Carter 1956). 11-12 Conicocassis pontigulasiformis (Beyens, Chardez, and De Bock, 1986) Nasser and Patterson, 2015. 13 Hyalosphenia papilio Leidy, 1874. 14 Heleopera sphagni Leidy, 1874. 15-16 Lagenodifflugia vas (Leidy 1874). 17-18 Lesquereusia spiralis (Ehrenberg 1840). 19-20 Pontigulasia compressa (Carter 1864) 194

Figure 5. 3: Scanning electron microscope plate of Arcellinida specimens from Frame Lake and Hambone Lake. 1-2 Phryganella nidulus Penard 1902. 3-4 Difflugia glans (Penard 1902) strain "glans". 5-6 Difflugia glans (Penard 1902) strain “distenda". 7-8 Difflugia globulosa (Dujardin, 1837) Penard, 1902. 9 Difflugia urceolata Carter 1864 strain "urceolata". 10-11 Difflugia oblonga (Ehrenberg 1832) strain "oblonga”. 12-13 Difflugia oblonga (Ehrenberg 1832) strain "tenuis". 14 Difflugia oblonga (Ehrenberg, 1832) strain "lanceolata". 15-16 Difflugia elegans (Penard 1890). 17-18 Difflugia protaeiformis Lamark 1816 
strain "acuminata". 19 Difflugia protaeiformis Lamark 1816 strain "claviformis". 20 Difflugia curvicaulis Penard 1899.............................................................. 196

Figure 5. 4: Arcellinida assemblages based on A two-way heatmap cluster analysis. The two-way heat map dendrogram shows the relative abundance of the 25 identified Arcellinida species and strains (R-mode; horizontal dendrogram) in the sample of the identified assemblages (Q-mode; vertical dendrogram). The coloured numbers on the Q-mode dendrogram represents the results of PVClust analysis that shows the statistical significance of the identified assemblages (red numbers). 199

Figure 5. 5: Nonmetric Multidimensional Scaling (NMDS) bi-plot. The coloured symbols represent the samples of the identified assemblages in Frame Lake and Hambone Lake. CCA, Centropyxis aculeata "aculeata”.CCD, Centropyxis aculeata "discoides". CCA, Centropyxis constricta "aerophila". CCC, Centropyxis constricta “constricta”. CT, Cucurbitella tricuspis. CP, Conicocassis pontigulasiformis. HP, Hyalosphenia papilio. HS, Heleopera sphagni. LV Lagenodifflugia vas. LS Lesquereusia spiralis. PC Pontigulasia compressa. $\mathrm{PhN}$, Phryganella nidulus. DGG, Difflugia glans "glans”. DGD, Difflugia glans “distenda”. Dglob Difflugia globulosa. DUU, Difflugia urceolata "urceolata". DOO, Difflugia oblonga “oblonga”. DOT, Difflugia oblonga "tenuis". DOLan, Difflugia oblonga "lanceolata". DE, Difflugia elegans. Dbi, Difflugia bicornis. DA, Difflugia 
protaeiformis "acuminata". DCl, Difflugia protaeiformis "claviformis". DCur, Difflugia curvicaulis. 202

Figure 5. 6: Redundancy analysis (RDA) tri-plots and variance partitioning results. The coloured symbols represent the samples of the identified assemblages in Frame Lake and Hambone Lake. The dark blue lines represent the variables selected in both lakes. CCA, Centropyxis aculeata "aculeata".CCD, Centropyxis aculeata "discoides". CCA, Centropyxis constricta "aerophila". CCC, Centropyxis constricta "constricta". CT, Cucurbitella tricuspis. CP, Conicocassis pontigulasiformis. HP, Hyalosphenia papilio. HS, Heleopera sphagni. LV Lagenodifflugia vas. LS Lesquereusia spiralis. PC Pontigulasia compressa. PhN, Phryganella nidulus. DGG, Difflugia glans "glans". DGD, Difflugia glans “distenda". Dglob Difflugia globulosa. DUU, Difflugia urceolata "urceolata". DOO, Difflugia oblonga "oblonga". DOT, Difflugia oblonga "tenuis". DOLan, Difflugia oblonga "lanceolata”. DE, Difflugia elegans. Dbi, Difflugia bicornis. DA, Difflugia protaeiformis "acuminata". DCl, Difflugia protaeiformis "claviformis". DCur, Difflugia curvicaulis. 205 


\section{List of Tables}

Table 2. 1: Sample preparation techniques employed in 44 Arcellinida studies

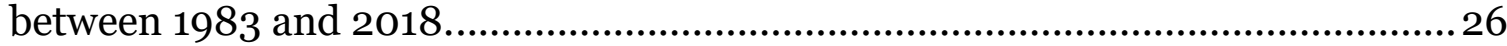

Table 2. 2: Total organic matter (TOC) and Particle size analysis results for YK20, YK25, and YK57........................................................................................ 33

Table 2. 3: Raw Arcellinida counts for the control and $5 \% \mathrm{KOH}$ treated subsamples of YK20, YK25, and YK57. 


\section{List of Plates}

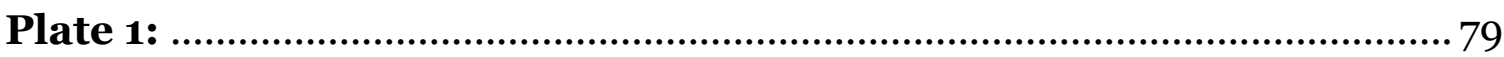

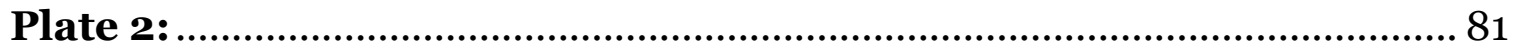

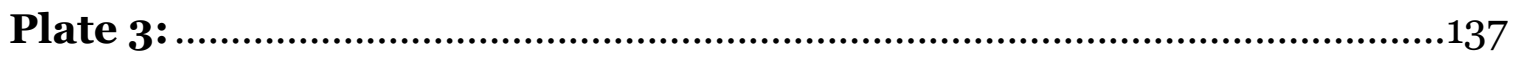

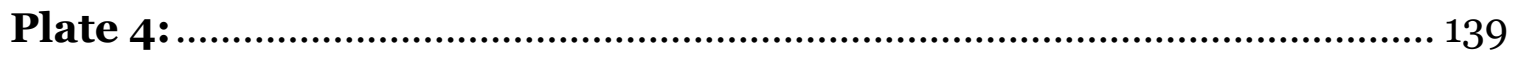

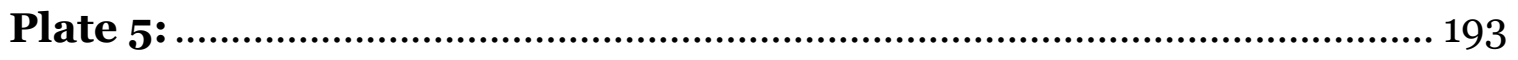

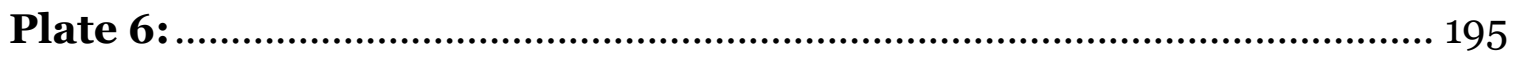




\section{Chapter 1}

\section{Introduction}

\subsection{Research background and motivation}

The research presented in this $\mathrm{Ph} . \mathrm{D}$. dissertation is a crucial component of a multidisciplinary and collaborative project that has been jointly funded by Polar Knowledge Canada (POLAR) and the Geological Survey of Canada (GSC) to develop geoscience tools for assessing environmental risk associated with metal mining in northern Canada. The long-term objectives of this project are: 1) to produce novel cumulative effects models for land-use change; 2) to develop reliable tools that support environmental risk assessment of metal mining; 3) to enhance the quality and performance of Canada's environmental regulatory process; and, 4) to generate relevant Traditional Ecological Knowledge (TEK), experiences acquired by indigenous and local peoples over hundreds of years of direct human contact with the environment (Berkes, 1993; Inglis, 1993) and Inuit Qaujimajatuqangit (IQ) knowledge products that can benefit northern communities. The second and third objectives, in specific, provide the impetus for my Ph.D. research, which is focused on further developing Arcellinida, also known as testate lobose amoebae (Mitchell et al., 2008), as a robust tool for monitoring legacy arsenic (As) contamination derived from the operations of historic gold mines in the central Northwest Territories (NT), Canada.

It is undeniable that the mining industry in northern Canada has been a vital driver of the nation's economic development (production value since 1974 = $\$ 65$ billion; NRCan, 
2019). Gold mining, in particular, contributed substantially to the establishment of the City of Yellowknife as the capital of the NT with several major gold mining operations, notably Giant Mine (1948-2004), Con/Negus Mine (1938-2003), and Discovery Mine (19501969), that collectively produced 382.7 tonnes of gold and generated $\$ 5.51$ billion (in 2002 \$) in revenue since 1983 (Bullen and Robb, 2005). The operations of these mines, however, left behind a massive legacy of As contamination in surrounding environments that poses significant risk to the environment and human health. In response to this environmental liability, several mine remediation efforts have been initiated across the central NT (e.g., the Giant, Discovery, and Tundra mines remediation projects; Silke, 2009) and were supplemented by the introduction of the Mine Site Reclamation Policy for the NT in 2002, which stipulates that operators of new and existing mines must not only present a comprehensive closure and reclamation plan, but also restore conditions at any sites or environments impacted by the mining activities and monitor the progress of remedial efforts at these sites post mine-closure (INAC, 2002).

Of the many As contamination-impacted environments and ecosystems in the NT, the contamination of lake sediments and waters by As has received special attention due to the value of lakes as: 1) an essential source of drinking water; 2) a habitat that sustains a plethora of aquatic fauna and flora; 3 ) a driver of socio-economic growth (e.g., they serve as transportation and trade routes, and/or popular recreational sites); and; 4) integral sites for domestic use, irrigation, grazing, and fishing for the Yellowknives Dene First Nation and other Indigenous communities (Tides Canada, 2015). Concerns over the deleterious impact of As contamination on lacustrine ecological conditions is attributed mainly to the high toxicity of this metalloid and the redox-sensitivity of As, which allows it to cycle 
between the sediments and overlaying water post-depositionally in response to seasonal variations in abiotic (e.g., changes in $\mathrm{pH}$ and dissolved oxygen) and biotic lacustrine parameters (e.g., microbial activities; Toevs et al., 2006; Du Laing et al., 2009). Due to the cyclic behaviour of As, lake sediments can either act as a repository for As, typically under oxic conditions, or a source that can release As from sediment to porewaters and subsequently to overlying surface waters under reducing conditions (e.g., Palmer et al., 2019). Therefore, accurate monitoring of environmental conditions in As contaminated and uncontaminated lakes is critical to ensure the rehabilitation of the former and safeguard the integrity of ecological conditions in the latter.

The impact of mine-derived As contamination on lakes has spurred several lake restoration and environmental monitoring programs in the NT (e.g., SENES, 2011; Reid, 2012; AANDC, 2014; AECOM, 2015; Tides Canada, 2015). Monitoring the progress of remediation in impacted lakes is typically achieved by collecting and analyzing water and sediment samples for element concentrations (e.g., Reid, 2012; AANDC, 2014). Lake sediments represent one of the most significant archives for past environmental changes (Last and Smol, 2001). This is because lake sediments contain chemical, sedimentological, and biological proxies that can be used to track changes in lake environmental conditions. Of these proxies, biological proxies can provide a time-averaged multi-seasonal signal of environmental conditions and therefore have the potential to be a reliable tool for monitoring the efficacy of remediation. Further, biological proxies can provide information on the direct ecological impacts of contamination and are not post-depositionally remobilized (assuming a lack of bioturbation) as is the case for redox sensitive elements such as As. 


\subsubsection{Arcellinida (testate lobose amoebae)}

Benthic shelled microorganisms, in particular, have been shown to record the impact of land-use on the ecological health of lakes overtime (e.g., Gavel et al., 2018; Nasser et al., 2019). However, fossils of certain benthic microorganisms may not preserve well after burial under specific environmental conditions (e.g., molluscs shells and ostracod valves tend to dissolve under acidic conditions; Overrein et al., 1980; Raddum, 1980, Rooke, 1983; Servos et al., 1984; Ruiz et al., 2013). Conversely, the fossil remains of Arcellinida are characterized by an elevated preservation potential under a wide range of lacustrine environmental condition, and are therefore very reliable as bioindicators of environmental change (Medioli and Scott, 1988; Kumar and Patterson, 2000). Arcellinida are a group of microscopic $($ size $=15-200 \mu \mathrm{m})$ benthic protozoans that are abundant in Quaternary deposits of fresh (e.g., lakes, rivers and peatlands) and brackish aquatic habitats (Medioli and Scott, 1988; Patterson et al., 1985; Charman, 2000). The geographical range of Arcellinida is wide, extending from the tropics to the Arctic region (Collins et al., 1990; Beyens et al., 1995; Dalby et al., 2000; Escobar et al., 2008). The amoeboid cell is enclosed within a single-chambered test (i.e., shell) that is either secreted by the organism (autogenous tests) or constructed by binding particles and detritus from the environment (xenogenous tests; Medioli and Scott, 1988; Patterson and Kumar, 2002). While arcellinidan tests are most common in Holocene deposits, intact tests have been also found in deposits dating for the Cretaceous and the Neoproterozoic (Porter and Knoll, 2000; van Hangstum et al., 2007).

Arcellinida species were identified and described as far back as the early $19^{\text {th }}$ century (Schrank, 1802; Lamarck, 1816). The majority of early Arcellinida studies 
primarily focused on exploring the taxonomic aspect of the group (i.e., description of new genera and/or species; e.g., Lamarck, 1816; Ehrenberg, 1838; Perty, 1849; Wallich, 1864; Leidy, 1877; Hampel, 1898; Penard, 1902; Cash and Hopkinson, 1905; Deflandre, 1961; Loeblich and Tappan, 1964; Ogden and Hadley, 1980). Taxonomic-based studies dominated the Arcellinida literature for almost 180 years (1802-1980), with the ecology, distribution, and applications of lacustrine Arcellinida receiving limited attention (Lindberg, 1899; Tolonen, 1986; Lagerheim, 1902). However, interest in Arcellinida and their ecological potential experienced a revival that began in Europe in the 1970s and 1980s, with studies by Schönborn (1973, 1984) and Ruzicka (1982) successfully demonstrating the potential of using the group for reconstructing paleoenvironmental conditions in lakes. The studies have also showcased the sensitivity of Arcellinida species to the impact of erosion and sediment influx (Ruzicka, 1982) and variations in the trophic status of lakes (Schönborn, 1984). The findings of these studies paved the way for subsequent investigations of the ecological potential of Arcellinida in Europe (e.g. Ellison, 1995; Asioli et al., 1996) and resulted an even greater resurgence of Arcellinida research in North America (e.g., Scott and Medioli, 1983; Patterson et al., 1985; Honig and Scott, 1987; Medioli and Scott, 1988).

Several ecological studies on the group are of particular note. In Canada, Scott and Medioli (1983) detected a notable change in the temporal distribution of Arcellinida assemblages, in sedimentary cores from the three basins in Lake Erie, and interpreted their observations as a response to possible land-use changes around the lake in $1850 \mathrm{AD}$ (e.g. human settlement). The authors also recognized a linked between the abundance of Cucurbitella tricuspis and eutrophication and correlated the increase in the numbers of 
Difflugia bidens to periods of increased sedimentary input. A few years later, Patterson et al. (1985) identified a clear arcellinidan response to environmental changes from marine to freshwater conditions in sedimentary cores from five lakes in New Brunswick and Nova Scotia. The authors also reported elevated numbers of Centropyxis aculeata in sedimentary horizons marking the environmental transition and corroborated the findings of Scott and Medioli (1938) by linking the abundance of C. tricuspis and D. bidens to eutrophication and elevated minerogenic content, respectively. In addition, the authors refined knowledge pertinent to the ecology of C. tricuspis by linking its abundance with eutrophication as well as the abundance of floating algae (Spyrogyra). Honig and Scott (1987) further confirmed the sensitivity of Arcellinida assemblages to changes in sea level and corroborated the results of Patterson et al. (1985), by showing a clear faunal response to the environmental transition from marine to freshwater conditions in small lakes in coastal New Brunswick.

Following these key studies, Arcellinida research output saw a significant increase in the number of studies investigating the distribution, diversity, and ecology of Arcellinida in lakes from North America (e.g., Collins et al., 1990; Escobar et al., 2008; Neville et al., 2010; Segala et al., 2017), Europe (e.g., Lokko et al., 2014; Sakauskiene et al., 2014; Varol et al., 2015), Asia (Chung and Choi, 1989, 1995; Dalby et al., 2000; Yang et al., 2005, 2009; Ju et al., 2014; Yu and Tahirova, 2018), and South America (e.g., Escobar et al., 2005; Alves et al., 2010; Cauffau et al., 2015) — to date, there have been no Arcellinida studies from African lakes (Schwind et al., 2013). This line of research further evolved to include studies aiming to assess the use of Arcellinida as bioindicators of land-use impact. For example, several studies have illustrated the effects of anthropogenically-derived changes in $\mathrm{pH}$ on the distribution of Arcellinida (Asioli et al., 1996; Kumar and Patterson, 
2000; Escobar et al., 2008; Neville et al., 2010; Patterson et al., 2013; Qin et al., 2013), while other researchers have confirmed the sensitivity of Arcellinida to the impact of eutrophication (Reinhardt et al, 2005; Yang et al., 2005; Roe et al., 2010; Patterson et al., 2012; Gavel et al., 2018). A facet of Arcellinida research that has been recently attracting a lot of attention, and is the primary motivation for my Ph.D. research, is the assessment of the response of Arcellinida assemblages to contamination derived from mineral resource development (i.e. mining).

In the late 1990s, studies from Italy (Asioli et al., 1996) and Canada (Patterson et al, 1996; Reinhardt et al., 1998) demonstrated the sensitivity of Arcellinida populations to the impact of mine-induced contamination. The same studies also recognized a notable faunal transition from stressed to healthy Arcellinida assemblages concurrent with reduced levels of contamination. In subsequent years, quantification of the spatio-temporal relationship between Arcellinida assemblages and mine-derived contaminants became possible thanks to advancements in the field of statistics (e.g., Kauppila et al., 2006; Kihlman and Kauppila, 2009, 2010, 2012; Patterson et al., 2013). Recently, Nasser et al (2016) quantified, for the first time, the relationship between legacy arsenic contamination derived from the operations of Giant Mine and Arcellinida assemblages in 61 near-surface sediment samples from 59 lakes in the Yellowknife area, Northwest Territories, Canada. While the results of that study provided new insight into the sensitivity of Arcellinida to As contamination, there is still much room for refining the use of Arcellinida as a tool for monitoring As contamination and the progress of remediation in impacted lake. 


\subsection{Research objectives and originality}

The primary aim of this project was to further develop Arcellinida as a robust tool for monitoring the impact of As contamination and progress of remediation in lakes. To that end, this Ph.D. research was designed to address multiple goals:

1. To develop an Arcellinida sample processing protocol to enhance the efficiency of arcellinidan analysis by reducing organic content in lake sediment samples (Chapter 2; Nasser et al., 2019);

2. To determine whether duplicate sampling for Arcellinida analysis is necessary from similar lacustrine environments (Chapter 3; Nasser et al., 2019);

3. To discern whether Arcellinida assemblages are sensitive enough to detect shortterm environmental changes (i.e. inter-annual; Chapter 3; Nasser et al., 2019);

4. To quantify the response of Arcellinida to mine-induced arsenic contamination at a regional scale (i.e. inter-lake survey) and determine arsenic tolerance-limits of different arcellinidan species (Chapter 4; Nasser et al., In Review); and,

5. To quantify the response of Arcellinida to mine-induced arsenic contamination at a local scale (i.e. intra-lake survey) and assess the consistency of Arcellinida response to legacy arsenic contamination derived from two different gold mines (Chapter 5; Nasser et al., submitted)

These goals are addressed in four peer-reviewed articles that represent four chapters in this integrated Ph.D. dissertation (Chapters 1-4). The first research article (Chapter 1; Nasser et al., 2019) addresses the first research goal by assessing the impact of three chemical treatment methods; soda ash $\left(\mathrm{Na}_{2} \mathrm{CO}_{3} \cdot \mathrm{H}_{2} \mathrm{O}\right)$, potassium hydroxide $(\mathrm{KOH})$, and sodium hexametaphosphate $\left(\left(\mathrm{NaPO}_{3}\right)_{6}\right)$, on organic content reduction and arcellinidan test 
preservation in 126 subsample aliquots derived from three near-surface sediment samples from three lakes near the City of Yellowknife, Northwest Territories, Canada to: 1) determine the optimal chemical treatment method and chemical concentration for reducing organic content in arcellinidan sediment samples; 2) assess the level of arcellinidan test damage resulting from the use of each treatment method; and, 3) examine the effect of chemical treatment and residual organic content on Arcellinida analysis and arcellinidan assemblages faunal composition. This research represents the first assessment of the use of chemical treatment as a valid method for enhancing the quality and efficiency Arcellinida analysis through reducing the organic content in lake samples, which is critical for enhancing the use of Arcellinida as a monitoring tool.

The second article (Chapter 3; Nasser et al., 2019) addresses the second and third research goals by examining Arcellinida specimens from 22 near-surface sediment samples collected from similar limnological environments in eastern Canadian lakes Lac du Castor Blanc (SW Quebec) and Oromocto Lake (SW New Brunswick), to: 1) evaluate the consistency of the faunal structure of Arcellinida assemblages found within the targeted homogenous environments; and, 2) assess the dynamics of arcellinidan assemblages in response to inter-annual limnological changes in samples collected from Oromocto Lake in 2010 and 2012 CE. This research is integral for developing Arcellinida as a monitoring tool as it confirmed whether collecting a single sample from similar lacustrine environments is enough to represent the Arcellinida populations, and showcased the sensitivity of Arcellinida to subtle short-term environmental changes.

The third article (Chapter 4; Nasser et al.; In review) addresses the fourth research goal by analyzing 93 near-surface sediment samples form 90 lakes within a radius of $\sim 30$ 
$\mathrm{km}$ around the former Giant Mine near the City of Yellowknife, NT, to determine the tolerance limits of different arcellinidan species and strains to varying As concentrations in order to identify As-indicator taxa or assemblages, and discerning whether quantifying Arcellinida assemblage dynamics in response to variations in As concentrations as a function of distance from Giant Mine can be used to delineate the extent of As aerial fallout zone of impact. This study represents the largest inter-lake spatial quantification of Arcellinida response to As concentration variability and the first attempt to determine the tolerance limit of Arcellinida taxa to variations in As concentration in lake systems.

The fourth article (Chapter 5; Nasser et al., Submitted) addresses the fifth research goal by examining Arcellinida tests in 40 near-surface sediment samples from two lakes impacted by arsenic (As) contamination associated with legacy gold mining in the central NT, Canada, to: 1) quantify the intra-lake relationship between Arcellinida and As; and, 2) evaluate whether the impact of As contamination derived from two former gold mines, Giant Mine (1938-2004) and Tundra Mine (1964-1968 and 1983-1986), on the Arcellinida distribution in both lakes are comparable or different.

Results from this integrated Ph.D. research will contribute significantly towards enhancing the quality and efficiency of Arcellinida analysis and provide quantitative evidence for the sensitivity of Arcellinida to As concentrations in impacted lakes. Such results further develop Arcellinida as a robust tool that can be used by mine developers and lacustrine restoration and monitoring programs to efficiently track changes in the level of As contamination, the ecological health of impacted lakes, and the efficacy of remedial and lake rehabilitation efforts. 


\subsection{Chapter References}

AANDC, 2014. Tundra Mine, NWT Remediation Environmental Monitoring Program: Water Quality Part L: 2013 and Historic Results. Available online: http://registry.mvlwb.ca/Documents/MV2009L8-0008/MV2009L80008\%20-\%20AANDC-CARD\%20\%202013\%20Annual\%20Report\%2ofor\%20Tundra\%2oMine\%20Site\%20 $-\% 20 M a r 27-14 . p d f$

AECOM, 2015. Tundra Mine, NWT Remediation Environmental Monitoring Program: Water Quality Part L: 2014 and Historical Results. Available online:http://registry.mvlwb.ca/Documents/MV2009L80008/MV2009L8-0008\%20-\%20AANDC-CARD\%20\%20Tundra\%20Mine\%202014\%20Annual\%20WL\%20Report\%20\%20May5-15.pdf

Alves GM, Velho LFM, Simões NR, Lansac-Tôha FA, 2010. Biodiversity of testate amoebae (Arcellinida and Euglyphida) in different habitats of a lake in the Upper Paraná River floodplain. European Journal of Protistology 46:310318.

Asioli A, Medioli FS, Patterson RT, 1996. Thecamoebians as a tool for reconstruction of paleoenvironments in some Italian lakes in the foothills of the southern Alps (Orta, Varese and Candia). The Journal of Foraminiferal Research 26:248-263. 
Berkes F, 1993. Traditional ecological knowledge in perspective. In Traditional ecological knowledge: Concepts and cases (Vol. 1). Canadian Museum of Nature/International Development Research Centre, Ottawa.

Beyens L, Chardez D, 1995. An annotated list of testate amoebae observed in the Arctic between the longitudes $27 \mathrm{E}$ and $168 \mathrm{~W}$. Archiv für Protistenkunde $146: 219-233$

Bullen WD, Robb ME, 2005. Socio-economic Contribution of Gold Mining in the Yellowknife Mining District, Chapter 4. In Anglin, Falck, Wright and Ambrose (Eds.), Gold in the Yellowknife Greenstone Belt, Northwest Territories: Results of the EXTECH III Multidisciplinary Research Project, Association of Canada, Mineral Deposits Division

Caffau M, Lenaz D, Lodolo E, Zecchin M, Comici C, Tassone A, 2015. First evidence of testate amoebae in Lago Fagnano (54 S), Tierra del Fuego (Argentina): proxies to reconstruct environmental changes. Journal of South American Earth Sciences 64:27-41.

Cash J, Hopkinson J, Wailes GH, 1905. The British Freshwater Rhizopoda and Heliozoa. Ray Scociety.

Charman DJ, Hendon D, Woodland WA, Quaternary Research Association, 2000. The Identification of Testate Amoebae (Protozoa: Rhizopoda) in Peats. Quaternary Research Association.

Chung W, Park J-B, 1995. A taxonomic study of order Arcellinida (Protozoa: Sarcomastigophora: Rhizopoda) from Korea (II). Animal Systematics, Evolution and Diversity 11:335-341. 
Collins ES, McCarthy FM, Medioli FS, Scott DB, Honig CA, 1990. Biogeographic distribution of modern thecamoebians in a transect along the eastern North American coast, p. 783-792 In: Paleoecology, Biostratigraphy, Paleoceanography and Taxonomy of Agglutinated Foraminifera, Springer.

Dalby A, Kumar A, Moore J, Patterson R, 2000. Preliminary survey of arcellaceans (thecamoebians) as limnological indicators in tropical Lake Sentani, Irian Jaya, Indonesia. The Journal of Foraminiferal Research 30:135-142.

Du Laing G, Chapagain S, Dewispelaere M, Meers E, Kazama F, Tack F, Rinklebe J, Verloo M, 2009. Presence and mobility of arsenic in estuarine wetland soils of the Scheldt estuary (Belgium). Journal of Environmental Monitoring 11:873-881.

Ellison RL, 1995. Paleolimnological analysis of Ullswater using testate amoebae. Journal of Paleolimnology 13:51-63.

Escobar J, Brenner M, Whitmore TJ, Kenney WF, Curtis JH, 2008. Ecology of testate amoebae (thecamoebians) in subtropical Florida lakes. Journal of Paleolimnology 40:715-731.

Escobar J, Martínez JI, Parra LN, 2005. Thecamoebians (Testaceous rhizopods) from a tropical lake: La Fe Reservoir, Antioquia, Colombia. Caldasia 27:293-298.

Gavel MJ, Patterson RT, Nasser NA, Galloway JM, Hanna BW, Cott PA, Roe HM, Falck H, 2018. What killed Frame Lake? A precautionary tale for urban planners. PeerJ 6:e485o. 
Honig C, Scott DB, 1987. Postglacial stratigraphy and sea-level change in southwestern New Brunswick. Canadian Journal of Earth Sciences 24:354364 .

INAC, 2002. Mine Site Reclamation Policy for the Northwest Territories. Indian and Northern Affairs Canada. Available online: https://www.lands.gov.nt.ca/sites/lands/files/resources/mine site recla mation policy - nwt.pdf

Inglis J, ed. 1993. Traditional ecological knowledge: concepts and cases. IDRC.

Ju L, Yang J, Liu L, Wilkinson DM, 2014. Diversity and distribution of freshwater testate amoebae (Protozoa) along latitudinal and trophic gradients in China. Microbial ecology 68:657-670.

Kauppila T, Kihlman S, Mäkinen J, 2006. Distribution of arcellaceans (testate amoebae) in the sediments of a mine water impacted bay of Lake Retunen, Finland. Water, air, and soil pollution 172:337-358.

Kihlman S, Kauppila T, 2010. Tracking the aquatic impacts of a historical metal mine using lacustrine protists and diatom algae. Mine water and the Environment 29:116-134.

Kihlman S, Kauppila T, 2012. Effects of mining on testate amoebae in a Finnish lake. Journal of paleolimnology 47:1-15.

Kihlman SM, Kauppila T, 2009. Mine water-induced gradients in sediment metals and arcellacean assemblages in a boreal freshwater bay (Petkellahti, Finland). Journal of Paleolimnology 42:533-550. 
Lagerheim G, 1902. Om la.amningar af rhizopoder, heliozoer ochtintinnider i Sveriges och Finlands lakustrina kvarta.araflagringar. Geologiske Fo.oreningens Forhandlunger 23, 469-520.

Lamarck JB, 1816. Histoire naturelle des animaux sans verte"ebres. Verdi"eere Paris 2, $1-568$.

Last WM, Smol JP, 2006. Tracking Environmental Change Using Lake Sediments: Volume 2: Physical and Geochemical Methods. Springer Science \& Business Media.

Leidy J, 1874. Notice of some new freshwater rhizopods. Journal of Natural History 14:383-385.

Lindberg H, 1899. En rik torffyndighet i Jorvis-socken Savolaks. Finska Mosskultur-fo.oreningens (AArsbok 1899, 178-213.

Loeblich AR, Moore RC, Tappan H, 1964. Treatise on Invertebrate Paleontology: Protista 2. Sarcodina Chiefly" Thecamoebians" and Foraminiferida.... University of Kansas Press.

Lokko K, Virro T, Kotta J, 2014. Taxonomic composition of zoopsammon in fresh and brackish waters of Estonia, a Baltic province ecoregion of Europe. Estonian Journal of Ecology 63(4).

Medioli F, Scott DB, 1988. Lacustrine thecamoebians (mainly Arcellaceans) as potential tools for palaeolimnological interpretations. Palaeogeography, Palaeoclimatology, Palaeoecology 62:361-386.

Mitchell EA, Payne RJ, Lamentowicz M, 2008. Potential implications of differential preservation of testate amoeba shells for paleoenvironmental reconstruction in peatlands. Journal of Paleolimnology 40:603-618. 
Nasser NA, Patterson RT, Roe HM, Galloway JM, Falck H, Palmer MJ, Spence C, Sanei H, Macumber AL, Neville LA, 2016. Lacustrine Arcellinina (Testate Amoebae) as bioindicators of arsenic contamination. Microbial ecology 72:130-149

Nasser NA, Gregory BR, Steele RE, Patterson RT, Galloway JM, 2019. Behind the Organic Veil: Assessing the Impact of Chemical Deflocculation on Organic Content Reduction and Lacustrine Arcellinida (Testate Amoebae) Analysis. Microbial ecology 1-16.

Nasser N, Cullen J, Patterson C, Patterson R, Roe H, Galloway J, 2019a. Interannual Arcellinida (testate lobose amoebae) assemblage dynamics within lacustrine environments. Limnologica 76:60-71.

Nasser NA, Gregory BR, Steele RE, Patterson RT, Galloway JM, 2019b. Behind the Organic Veil: Assessing the Impact of Chemical Deflocculation on Organic Content Reduction and Lacustrine Arcellinida (Testate Amoebae) Analysis. Microbial ecology 1-16.

Natural Resources Canada, 2019. Annual Statistics of Mineral Production. Natural Resources Canada. online: http://sead.nrcan.gc.ca/prod-prod/ann-anneng.aspx?FileT=2018\&Lang=en [accessed July 20, 2019]

Neville LA, McCarthy FM, MacKinnon MD, 2010. Seasonal environmental and chemical impact on thecamoebian community composition in an oil sands reclamation wetland in Northern Alberta. Palaeontologia Electronica 13:114.

Ogden G, Hedley RH, 1980. An atlas of freshwater testate amoebae. Soil Science 130:176. 
Overrein LN, Seip HM, Tollan A, 1980. Acid Precipitation-Effects on Forest and Fish. Final Report of the SNSF-Project 1972-1980.

Palmer MJ, Chételat J, Richardson M, Jamieson HE, Galloway JM, 2019. Seasonal variation of arsenic and antimony in surface waters of small subarctic lakes impacted by legacy mining pollution near Yellowknife, NT, Canada. Science of the Total Environment 684:326-339.

Patterson R, Baker T, Burbidge S, 1996. Arcellaceans (thecamoebians) as proxies of arsenic and mercury contamination in northeastern Ontario lakes. The Journal of Foraminiferal Research 26:172-183.

Patterson RT, Kumar A, 2002. A review of current testate rhizopod (thecamoebian) research in Canada. Palaeogeography, Palaeoclimatology, Palaeoecology 180:225-251.

Patterson RT, Lamoureux ED, Neville LA, Macumber AL, 2013. Arcellacea (testate lobose amoebae) as $\mathrm{pH}$ indicators in a pyrite mine-acidified lake, Northeastern Ontario, Canada. Microbial ecology 65:541-554.

Patterson RT, MacKinnon K, Scott DB, Medioli F, 1985. Arcellaceans (Thecamoebians) in small lakes of New Brunswick and Nova Scotia: modern distribution and Holocene stratigraphic changes. Journal of Foraminiferal Research 15:114-137.

Patterson RT, Roe HM, Swindles GT, 2012. Development of an Arcellacea (testate lobose amoebae) based transfer function for sedimentary phosphorus in lakes. Palaeogeography, Palaeoclimatology, Palaeoecology 348:32-44. 
Penard E, 1902. Faune Rhizopodique du Bassin du Lèman. Henry Kündig, Libraire de L’institut, Genéve pp 712

Porter SM, Knoll AH, 2000. Testate amoebae in the Neoproterozoic Era: evidence from vase-shaped microfossils in the Chuar Group, Grand Canyon. Paleobiology 26:360-385.

Raddum G, 1980. Comparison of benthic invertebrates in lakes with different acidity. In: International conference on the Ecological impact of acid precipitation. Sandefjord (Norway). 11-14 Mar 1980.

Reid R, 2012. Water Balance Monitoring at the Tundra Mine Site: 2012 Update Prepared for: Contaminants and Remediation Directorate. Aboriginal Affairs and Northern Development Canada. Available online: http://registry.mvlwb.ca/Documents/MV2009L8-0008/MV2009L80008\%20-\%20AANDC\%20-\%20CARD\%20\%20Tundra\%20Minesite\%202012\%20WL\%20Annual\%20Report\%20\%20Mar28-13.pdf

Reinhardt EG, Dalby AP, Kumar A, Patterson RT, 1998. Arcellaceans as pollution indicators in mine tailing contaminated lakes near Cobalt, Ontario, Canada. Micropaleontology 44:131-148.

Roe HM, Patterson RT, Swindles GT, 2010. Controls on the contemporary distribution of lake thecamoebians (testate amoebae) within the Greater Toronto Area and their potential as water quality indicators. Journal of Paleolimnology 43:955-975. 
Rooke JB, 1984. aspects of the biology of certain molluscs from six low-alkalinity lakes in south-central Ontario. Ph.D. thesis. Guelph University, Guelph, Ontario.

Ruiz F, Abad M, Bodergat AM, Carbonel P, Rodríguez-Lázaro J, GonzálezRegalado ML, Toscano A, García EX, Prenda J. 2013. Freshwater ostracods as environmental tracers. International Journal of Environmental Science and Technology 10(5), 1115-1128.

Ruzicka E, 1982. Die subfossilen Testaceen des Kr (Salzburg, .OOsterreich). Limnologica 1, 231-254.

Šatkauskienė I, 2014. Testate amoebae (Testaceae) of Lithuania. Biologija 60:.

Schrank F von P, 1802. Briefe naturhistorischen, physikalischen und ökonomischen Inhalts an Herrn Bernard Sebastian Nau, ehemaligen kurmainzischen Hofgerichtsrat und Professor-nebst drey vorausgeschickten naturhistorischen Abhandlungen. J.C. Schubart, 1-384.

Schwind LTF, Dias JD, Joko CY, Bonecker CC, Lansac-Tôha FA, 2013. Advances in studies on testate amoebae (Arcellinida and Euglyphida): a scientometric approach. Acta Scientiarum. Biological Sciences 35:549-555.

Scott DB, Medioli F, 1983. Agglutinated rhizopods in Lake Erie: modern distribution and stratigraphic implications. Journal of Paleontology 809820.

Schöonborn, W., 1984. Studies on remains of testacea in cores of the Great Woryty Lake (NE-Poland). Limnologica 16, 185-190. 
SENES Consultants Limited (SENES). 2005. Air quality moni- toring at Giant Mine site- Yellowknife: a baseline study. In: INAC (2007): Giant Mine Remediation Plan, supporting document A11. 67pp

Servos M, Rooke J, Mackie G, 1985. Reproduction of selected mollusca in some low alkalinity lakes in south-central Ontario. Canadian journal of zoology 63:511-515.

Sigala I, Lozano-García S, Escobar J, Pérez L, Gallegos-Neyra E, 2016. Testate amoebae (Amebozoa: Arcellinida) in tropical lakes of Central Mexico. Revista de biologia tropical 64:377-397.

Silke R. 2009. The operational history of mines in the Northwest Territories. Canada An Historical Research Project. Available online: https://buyandsell.gc.ca/cds/public/2014/05/27/edcb878b7f96e1d30e53 59a53406c671/ABES.PROD.PW_NCS.B107.E10183.ATTA040.PDF

Tides Canada. 2015. Frame Lake Rehabilitation Project receives RBC Blue Water Fund Support. Tides Canada. Available online: https://tidescanada.org/inthe-news/frame-lake-rehabilitation-project-receives-rbc-blue-water-fundsupport/ [accessed September 21st 2019]

Toevs GR, Morra MJ, Polizzotto ML, Strawn DG, Bostick BC, Fendorf S, 2006. Metal (loid) diagenesis in mine-impacted sediments of Lake Coeur d'Alene, Idaho. Environmental science \& technology 40:2537-2543.

Van Hengstum P, Reinhardt E, Boyce J, Clark C, 2007. Changing sedimentation patterns due to historical land-use change in Frenchman's Bay, Pickering, Canada: evidence from high-resolution textural analysis. Journal of Paleolimnology 37:603-618. 
Varol M, Mazei YA, Bekleyen A, 2015. First Records of Freshwater Testate Amoebae in Turkey. Известия высших учебных заведений. Поволжский регион. Естественные науки 101-108.

Yang J, Zhang W, Shen Y, 2009. Relationships between testate amoebae assemblages (Protozoa) and geographic factors in Yunnan Plateau lakes, China. Journal of Freshwater Ecology 24:437-443.

Yu SN, 2018. The new and rare species of the testate amoebae (Amoebozoa: Arcellinida) from mountain lakes of Azerbaijan. Protistology 12 


\section{Chapter 2}

\section{Behind the organic veil: assessing the}

impact of chemical deflocculation on

organic content reduction and lacustrine

\section{Arcellinida (testate amoebae) analysis}

Nawaf A. Nasser ${ }^{1}$, Braden R.B. Gregory ${ }^{1}$, Riley E. Steele ${ }^{1}$, R. Timothy Patterson ${ }^{1}$, Jennifer M. Galloway ${ }^{2,3}$

1 Ottawa-Carleton Geoscience Centre and Department of Earth Sciences and, Carleton University, 1125 Colonel By Drive, Ottawa, Ontario, K1S 5B6 Canada

2 Geological Survey of Canada/Commission géologique du Canada, Calgary, Alberta, Canada, T2L 2A7

3 Aarhus Institute of Advanced Studies, Aarhus University, Aarhus, Denmark, 8000 


\subsection{Abstract}

Arcellinida (testate lobose amoebae) are widely used as bio-indicators of lacustrine environmental change. Too much obscuring organic material in a gridded wet petri dish preparation makes it difficult to observe all specimens present, and slows quantification as the organic material has to be carefully worked through with a dissection probe. Chemical deflocculation using soda ash $\left(\mathrm{Na}_{2} \mathrm{CO}_{3} \cdot \mathrm{H}_{2} \mathrm{O}\right)$, potassium hydroxide $(\mathrm{KOH})$, or sodium hexametaphosphate $\left(\left(\mathrm{NaPO}_{3}\right)_{6}\right)$ has previously been shown to disaggregate and reduce organic content in lake sediments, but to date, no attempt has been made to comparatively evaluate the efficiency of these deflocculants in disaggregating organic content and their impact on Arcellinida analysis in lacustrine sediments. Here we assess the effectiveness of soda ash, potassium hydroxide, and sodium hexametaphosphate treatments on removing organic content and the impact of those digestions on Arcellinida preservation in 126 sample aliquots subdivided from three sediment samples (YK20, YK-25, and YK-57) collected from three lakes near Yellowknife, Northwest Territories, Canada. Following treatment, cluster analysis and Bray-Curtis Dissimilarity Matrix (BCDM) were utilized to determine whether treatments resulted in dissolution driven changes in Arcellinida assemblage composition. Observed Arcellinida tests in aliquots increased drastically after treatment of organic-rich samples $(47.5-452.7 \%$ in organic rich aliquots and by $14.8 \%$ in aliquots with less organic matter). The BCDM results revealed that treatment with $5 \% \mathrm{KOH}$ resulted in the highest reduction in observed organic content without significantly affecting Arcellinida assemblage structure, while soda ash and sodium 
hexametaphosphate treatments resulted in marginal organic matter reduction and caused severe damage to the arcellinidan tests.

Keywords: Arcellinida, lake sediments, organic content, chemical treatment, sample preparation methods, arcellinidan analysis

\subsection{Introduction}

Arcellinida (testate lobose amoebae) are a cosmopolitan group of benthic shelled

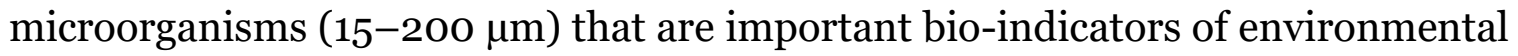
change in fresh and brackish water aquatic systems (Charman, 2001; Patterson and Kumar, 2002). The group are characterized by tests (i.e. shells) that are either secreted by the organism or constructed by binding particles from the surrounding environment (e.g. sediment particles and/or diatoms frustules), with the latter type being of greater use in limnological and paleolimnological studies (Patterson and Kumar, 2002). Arcellinida analysis of samples derived from lake sediments generally involves identifying and quantifying tests in wet preparations in a petri dish under a dissecting microscope. Prior to analysis it is desirable to remove as much organic and minerogenic material as possible as this extraneous matter obscures specimens. In the early 1980s, Arcellinida researchers adapted the approach used in analysis of foraminifera in organic rich salt marsh samples (e.g. Scott and Medioli, 1983; Patterson et al, 1985; Medioli and Scott, 1988) to lacustrine environments. That sample preparation protocol involves gently 
washing sediment samples through coarse $(500-1000 \mu \mathrm{m})$ and fine $(44-63 \mu \mathrm{m})$ sieves to remove organic and minerogenic particles that are larger and smaller than arcellinidan tests. Scott and Hermlin (1993) complemented sieving with using an improved version of the Elmgren (1973) wet splitter, which allowed for dividing sieved samples into smaller and more manageable aliquots.

While sieving and splitting still form the standard arcellinidan sample preparation protocol, variations in the mesh-size used for coarse $(1000-100 \mu \mathrm{m})$ and fine sieving (63-15 $\mu \mathrm{m}$ ), and types of wet splitter (six- vs. eight chambers) have been employed over the past 30 years (Table 2.1). A potential byproduct of these variations in preparation protocols is the introduction of various types of uncertainties during and after sample preparation that can negatively impact the quality of quantitative Arcellinida data. A few recent studies have investigated the potential statistical impact of preparation protocol variation focusing on the loss of arcellinidan tests during sample preparation (Payne et al., 2009; Avel and Pensa, 2013), the impact of using different filters on the density and species richness (Wall et al., 2010), and the effects of refrigerated sample storage on assemblage composition (Mazei et al., 2015). A potential source of uncertainty that has been overlooked is the impact of residual organic content on the quality of quantitative arcellinidan analysis.

Significant amounts of residual organic debris often survive the standard preparation processes and may mask or trap arcellinidan tests, which consequently impedes their analysis. Sample agitation, using either a stirring rod or laboratory benchtop wrist shaker, or repeating the process of sieving and splitting have been suggested as means to further loosen the organic colloidal 
Table 2. 1: Sample preparation techniques employed in 44 Arcellinida studies between 1983 and 2018.

\begin{tabular}{|c|c|c|c|c|c|}
\hline Author (s) & Year & $\begin{array}{c}\text { Coarse Sieving } \\
(\mu)\end{array}$ & $\begin{array}{c}\text { Fine Sieving } \\
(\mu)\end{array}$ & $\begin{array}{c}\text { Splitting (Scott } \\
\text { and Hermlin, } \\
\text { 1993) }\end{array}$ & $\begin{array}{c}\text { Chemical } \\
\text { Treatment }\end{array}$ \\
\hline Scott and Medioli & 1983 & 500 & 63 & No & \\
\hline Patterson et al & 1985 & 500 & 63 & No & \\
\hline Ellison and Ogden & 1987 & 100 & 44 & No & $6 \%$ Calgon \\
\hline Medioli and Scott & 1988 & 500 & 63 & No & \\
\hline Collins et al & 1990 & Not mentioned & 63 & No & \\
\hline Asioli et al & 1996 & Not mentioned & 45 & No & \\
\hline Patterson et al & 1996 & 1000 & 63 & Yes & \\
\hline Bubridge et al. & 1998 & Not mentioned & 44 & No & Soda ash \\
\hline Reinhardt et al & 1998 & 1000 & 55 & Yes & \\
\hline $\begin{array}{l}\text { Kliza and Shroeder- } \\
\text { Adams }\end{array}$ & 1999 & Not mentioned & 63 & No & \\
\hline Dalby et al & 2000 & 1000 & 43 & Yes & \\
\hline Dallimore et al & 2000 & Not mentioned & 44 & $\begin{array}{l}\text { Yes (eight } \\
\text { chambers) }\end{array}$ & \\
\hline Kumar and Patterson & 2000 & 1000 & 55 & Yes & \\
\hline Patterson and Kumar & 2000 & 1000 & 55 & Yes & \\
\hline Dalby et al & 2002 & 1000 & 43 & Yes & Soda ash \\
\hline Patterson and Kumar & $2002 a$ & 1000 & $40-55$ & Yes & \\
\hline Patterson and Kumar & $2002 b$ & 454 & 43 & Yes & \\
\hline Dallimore & 2004 & Not mentioned & 44 & Yes & \\
\hline Boudreau et al. & 2005 & 500 & 44 & Yes & \\
\hline Escobar et al & 2005 & Not mentioned & 63 & No & \\
\hline Reinhardt et al & 2005 & 150 & 45 & Yes & \\
\hline Kaupilla et al & 2006 & 1000 & 56 & $\begin{array}{l}\text { Yes (eight } \\
\text { chambers) }\end{array}$ & \\
\hline Roe and Patterson & 2006 & 250 & 37 & Yes & \\
\hline Escobar et al & 2008 & 707 & 53 & Yes & \\
\hline
\end{tabular}


Table 2. 1: Continued

\begin{tabular}{|c|c|c|c|c|c|}
\hline Author (s) & Year & $\begin{array}{c}\text { Coarse Sieving } \\
(\mu)\end{array}$ & $\begin{array}{c}\text { Fine Sieving } \\
(\mu)\end{array}$ & $\begin{array}{l}\text { Splitting (Scott } \\
\text { and Hermlin, } \\
1993 \text { ) }\end{array}$ & $\begin{array}{c}\text { Chemical } \\
\text { Treatment }\end{array}$ \\
\hline Kihlman and Kauppila & 2009 & 1000 & 56 & Yes & \\
\hline Lorencova & 2009 & 1000 & 36 & Yes & \\
\hline $\begin{array}{l}\text { Sonnenburg and } \\
\text { Reinhardt }\end{array}$ & 2009 & 250 & 45 & Yes & \\
\hline Kihlman and Kauppila & 2010 & 500 & 56 & Yes & \\
\hline Roe et al & 2010 & Not mentioned & 37 & Yes (not specified) & \\
\hline Neville et al & 2010 & 500 & 45,63 & No & \\
\hline Wall et al & 2010 & 250 & $25,47,63$ & No & \\
\hline Farooqui et al & 2012 & 105 & 20 & No & $5 \% \mathrm{KOH}$ \\
\hline Kihlman and Kauppila & 2012 & 500 & 56 & Yes & \\
\hline McCarthy et al & 2012 & Not mentioned & 63 & No & 10\% Calgon (HMP) \\
\hline Patterson et al & 2012 & 250 & 37 & Yes & \\
\hline Warchorn et al & 2012 & Not mentioned & 43 & No & \\
\hline Neville et al & 2013 & 250 & 37 & Yes & \\
\hline Patterson et al & 2013 & Not mentioned & 37 & Yes & \\
\hline Qin et al & 2013 & 300 & 35 & No & \\
\hline Sonnenburg et al & 2013 & 1000 & 250 & $\begin{array}{l}\text { Yes (eight } \\
\text { chambers) }\end{array}$ & \\
\hline Patterson et al & 2015 & 297 & 37 & Yes & \\
\hline Nasser et al & 2016 & 297 & 37 & Yes & \\
\hline Qin et al & 2016 & 500 & 35 & No & \\
\hline Segala et al & 2016 & Not mentioned & $\begin{array}{c}\text { Not } \\
\text { mentioned }\end{array}$ & No & \\
\hline Steel et al & 2018 & 297 & 37 & Yes & \\
\hline
\end{tabular}


content (e.g. Patterson et al., 1985; Medioli and Scott, 1988). However, these methods do not substantially reduce the total amount of organic content and may increase the potential of Arcellinida test loss during sample processing (e.g. process of decanting, sieving, and splitting; Collins et al., 1990). In order to better assess the impact of the organic content on arcellinidan analysis, the development of a more robust sample preparation technique that can maximize the reduction of the organic content is required.

Numerous studies on lacustrine (e.g. chironomids; Peter et al., 2001; Brooks, 2000) and marine bio-indicators (e.g. foraminifera; Barker et al., 2003; Feldmeijer et al., 2013) have utilized chemical deflocculation to disaggregate organic and minerogenic colloidal content prior to sample preparation. Chemical sample preparation methods often involve soaking sediments in a known volume and concentration of a selected chemical deflocculant for a specific duration prior to sieving and splitting the sample. To the best of our knowledge, only a limited number of lacustrine arcellinidan studies employed chemical deflocculants including sodium hexametaphosphate $\left(\left(\mathrm{NaPO}_{3}\right)_{6}\right)$, sodium carbonate monohydrate (soda ash; $\mathrm{Na}_{2} \mathrm{CO}_{3} \cdot \mathrm{H}_{2} \mathrm{O}$ ), or potassium hydroxide $(\mathrm{KOH})$, to disaggregate and reduce amorphous organic content in lake sediment samples (e.g., Ellison and Ogden, 1985; Hendon and Charman, 1997; Burbidge and Schroder-Adams, 1998; Charman et al., 2010; Farooqui et al., 2012; McCarthy et al., 2012). The lack of enthusiasm amongst Arcellinida researchers to employ chemical deflocculation is attributed to a perception that the harsh nature of these methods may cause severe damage to Arcellinidan tests (Patterson and Kumar, 2002). Hendon and Charman (1997) have compared the effects of using several 
sample preparation methods, including $\mathrm{KOH}$ treatment, on peatland testate amoebae density, species richness, and test retention. While their study revealed that $\mathrm{KOH}$ treatment produced superior results in terms reduction of organic content and retention of arcellinidan tests, it also showed that treatment damaged a significant number of tests in the process thus impacting the statistical quality of the resultant quantitative arcellinidan analysis. The use of soda ash and sodium hexametaphosphate have also been reported to reduce organic content in lake sediments while causing little to no damage to arcellinidan tests (Ellison and Ogden, 1985; Burbidge and Schröder-Adams, 1998; McCarthy et al., 2012). However, no attempt has previously been made to compare the efficacy of organic content reduction using these various chemical deflocculants and to assess their impact on arcellinidan test preservation and associated assemblage structure in lake sediment samples.

In this study, we assess the impact of three chemical deflocculant treatment methods; soda ash $\left(\mathrm{Na}_{2} \mathrm{CO}_{3} \cdot \mathrm{H}_{2} \mathrm{O}\right)$, potassium hydroxide (KOH), and sodium hexametaphosphate $\left(\left(\mathrm{NaPO}_{3}\right)_{6}\right)$, on organic content reduction and arcellinidan test preservation in 126 subsample aliquots derived from three sediment-water interface samples (YK-20, YK-25, and YK-57) from three lakes near the City of Yellowknife, Northwest Territories, Canada. The study aims to: 1) determine the optimal deflocculant method and deflocculant chemical concentration for reducing organic content in arcellinidan bearing lake sediment preparations; 2) assess the level of arcellinidan dissolution caused by the various chemical treatment methods; and, 3) assess the impact of chemical treatment and residual organic content on arcellinidan analysis and faunal composition. 


\subsection{Study area}

The samples, used in this study were collected from three lakes located within a radius of $\sim 30 \mathrm{~km}$ around the City of Yellowknife, Northwest Territories, Canada (Figure 2.1). The elevation of the study area ranges from $157 \mathrm{~m}$ above mean sea level (AMSL) close to Great Slave Lake to 350-400 m AMSL to the north of Thistlethwaite Lake (Kerr and Wilson, 2000). The Yellowknife River, the main drainage system in the study area, flows southward into Yellowknife Bay of the Great Slave Lake. The study area is characterized by a subarctic, continental climate where summers are short, dry, and cool with a mean annual temperature of $-4.3^{\circ} \mathrm{C}$ and a relatively low mean annual precipitation of $170.7 \mathrm{~mm}$ (Environmental Canada, 2019).

Rocks underlying the investigated lakes belong to the Yellowknife Supergroup of the southern Slave structural province of the Canadian Shield. These include Archean metavolcanic and metasedimentary rocks intruded by younger granitoids and diabase dykes. Surficial sediments in the Yellowknife area are dominated by fine clastic lacustrine sediments deposited in Glacial Lake McConnell and a relatively thick $(<2 \mathrm{~m})$ and discontinuous layer of glacigenic sediments (Kerr and Wilson, 2000). Holocene-aged peat is also common in the study region and can be greater than $1 \mathrm{~m}$ thick in bogs and wetlands (Kerr and Wilson, 2000). 

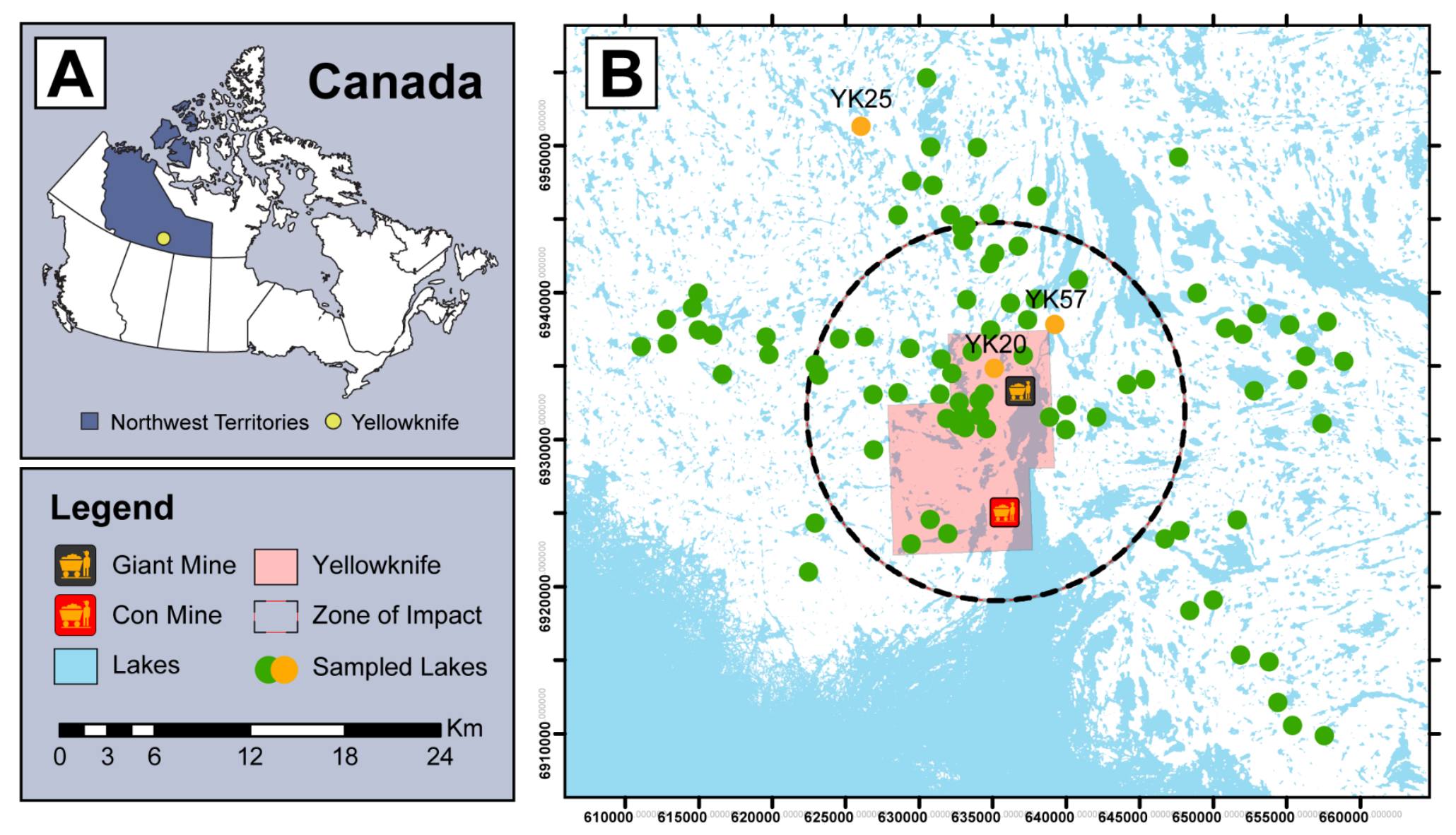

Figure 2. 1: A) Map of Canada showing the study location in the Northwest Territories, Canada (dark blue) as a yellow circle. B) A map showing sampling sites (green and yellow circles) within $30 \mathrm{~km}$ radius around the City of Yellowknife. Lakes sampled in this study $(\mathrm{n}=3)$ are represented as yellow circles. 


\subsection{Methodology}

\subsubsection{Sample selection}

The 126 aliquots analyzed here were subsampled from three samples (YK20, YK25, and YK57) collected in June 2014 using an Ekman grab (Figure 2.1). More than 100 lakes from this area are being investigated as part of an inter-lake spatial assessment of the impact of legacy gold mine-induced arsenic contamination on the arcellinidan distribution within a radius of $30 \mathrm{~km}$ around the City of Yellowknife (Nasser et al., 2016, 2019). The three lakes selected for this study were chosen to include samples with both high and low total organic carbon (TOC) from that large data set based on observed organic concentration using Rock-Eval ${ }^{\circledR}$ Analysis 6, as well as visual inspection of the density of amorphous organic matter under a dissecting microscope. The highest organic content density and TOC (26.38\%) was observed in YK20. Surprisingly, YK57 is also characterized by high

observed organic content density even though the sample's TOC is the lowest a (7.03\%). In contrast, a low organic matter density was observed in YK25 despite the relatively higher TOC of the sample (26.08\%) (Table 2.2).

\subsubsection{Arcellinida Taxonomy}

The arcellinidan species and strains were identified using several well-illustrated papers that employed the strain taxonomic concept (e.g., Kumar and Dalby, 1998; Reinhardt et al., 1998; Roe et al 2010; Patterson et al., 2012 Patterson et al., 2013; Macumber et al., 2014; Neville et al., 2014; Patterson et al., 2015; Nasser et 
Table 2. 2: Total organic matter (TOC) and Particle size analysis results for YK20, YK25, and YK57.

\begin{tabular}{c|c|c|c|c}
\hline \multirow{2}{*}{ Site ID } & Rock Eval & \multicolumn{3}{|c}{ Particle Size Analysis } \\
\cline { 2 - 5 } & TOC (\%) & Sand (\%) & Silt (\%) & Clay (\%) \\
\hline YK20 & 26.38 & 5.87 & 76.82 & 17.31 \\
YK25 & 26.08 & 13.61 & 71.19 & 15.2 \\
YK57 & 7.03 & 10.13 & 77.43 & 12.44 \\
\hline
\end{tabular}

al., 2016). As lacustrine arcellinidan species can display a significant amount of environmentally controlled morphological variability (e.g., Medioli and Scott, 1983; Medioli et al. 1987), the accepted practice has been to designate informal infrasubspecific "strain" names for these ecophenotypes (Patterson and Kumar, 2002; Asioli et al., 1996). Infrasubspecific level designations have no status under the International Zoological Code of Nomenclature (art. 45.5; 4th edition, 1999). However, they have been extensively used in the literature for delineating environmentally significant populations within lacustrine environments (Reinhardt et al. 1998; Patterson and Kumar, 2000; Patterson and Kumar, 2002; Roe and Patterson, 2006; Escobar et al 2008; Kihlman and Kaupila, 2009).

\subsubsection{Chemical treatment methods}

To determine the most efficient combination of treatment method, chemical concentration, and treatment exposure time for reducing the organic content in arcellinidan samples, the experimental component of the study was divided into three testing stages. Figure 2 provides an overview of the standard arcellinidan 
sample preparation method (Figure 2.2A) and the steps followed during the three chemical testing stages (Figure 2.2B, C, D). Nine subsamples (three $\mathrm{cm}^{3}$ each) were collected from the YK2O, YK25, and YK57 lake sediment grab samples (three subsamples per YK sample) to carry out the first testing stage. Each of the nine subsamples was divided into six aliquots using a wet splitter, resulting in a total of 54 aliquots (Scott and Hermlin, 1993). The aliquots were then centrifuged at 4000 rpm for four minutes and excess water was carefully decanted to mitigate diluting the chemical concentrations that were to be added to each sub-sample. A single aliquot from each sample served as a control sub-sample and was prepared following the standard arcellinidan sample preparation protocol described above (Figure 2.2A), while the remaining aliquots were treated using $20 \mathrm{ml}$ of five different concentrations of soda ash, $\mathrm{KOH}$, and sodium hexametaphosphate for three hours (Figure 2.2B). After three hours, all treated aliquots were gently sieved using $297 \mu \mathrm{m}$ (30 seconds) and $37 \mu \mathrm{m}$ sieves (2 minutes). The aliquots were then placed in a gridded Petri dish and the proportion of residual organic content was visually inspected under an Olympus SZH dissecting binocular microscope. Photomicrographs of random grids for treated and control aliquots were taken to determine the difference between the amount of organic content reduced by the chemical treatment methods and the standard sample preparation protocol (Figures 2.3, 2.4, 2.5). The chemical concentration of each chemical deflocculant responsible for reducing the highest proportion of organic content was selected for further testing. 

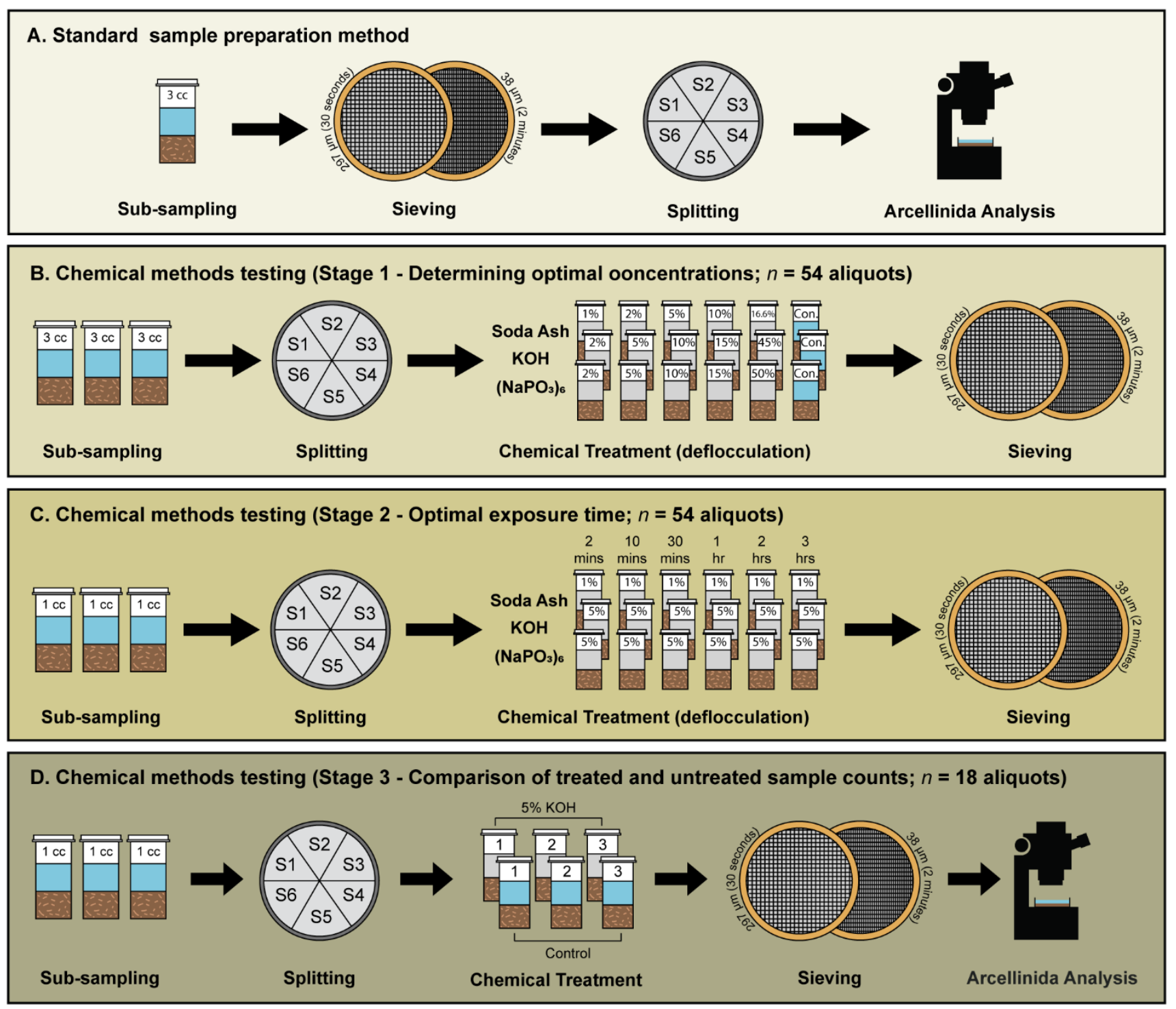
Figure 2. 2: Schematic view of sample preparation methods used in this study. A) Standard Arcellinida sample preparation protocol. A sediment sample (often three $\mathrm{cm}^{3}$ ) is sieved through coarse (297 $\mu \mathrm{m}$; 30 seconds) and fine ( $38 \mu \mathrm{m}$; two minutes) sieves and split prior to arcellinidan analysis. B) First chemical methods testing stage, in which the impact of chemical treatment on organic content reduction was assessed. Three sediment subsamples (three $\mathrm{cm}^{3}$ each), from each YK sample, were split into six aliquots $(n=54)$. Five aliquots were treated with different concentrations of a chemical deflocculant for three hours before sieving. A single aliquot was processed following the standard sample preparation protocol (control subsample). C) Second chemical methods testing stage, in which optimal treatment duration was determined and impact on Arcellinida tests was assessed. Three sediment subsamples (one $\mathrm{cm}^{3}$ each), from each YK sample, were split into six aliquots $(n=54)$. Aliquots were treated with one selected concentration of each chemical deflocculant for different treatment durations prior to sieving. D) Third chemical methods testing stage. Three sediment subsamples (one $\mathrm{cm}^{3}$ subsample per YK sample) were split into six aliquots $(n=18)$. Three aliquots were treated with the optimal chemical method and concentration for three hours, and three were processed following the standard sample preparation protocol. Treated and control sub-samples were sieved prior to arcellinidan analysis. 
During the second stage of the experiment three $1 \mathrm{~cm}^{3}$ subsamples from each YK sample was split into six aliquots (total number of aliquots $=54$ ) and treated with the selected chemical concentrations for different time intervals prior to sieving (i.e. 2 minutes, 10 minutes, 30 minutes, 1 hour, 2 hours, and 3 hours; Figure 2.2C). This stage was essential for determining the optimal duration for the treatment and assessing the impact of the chemical treatment on the integrity of arcellinidan tests. The chemical method causing the least damage to Arcellinida tests was selected for further testing in stage 3 .

The final testing stage involved splitting an additional three $1 \mathrm{~cm}^{3}$ from each YK sample into six aliquots (total number of aliquots $=18$ ), treating three aliquots with the selected chemical, and preparing the remaining three aliquots following the standard sample preparation protocol (Figure 2.2A, D). Arcellinida in all aliquots were identified and quantified in totality to determine whether treating the subsample with the selected chemical treatment method will allow for identifying more arcellinidan tests, which would otherwise be concealed or trapped within the organic cover. Results from this stage were important for assessing the impact of residual organic content on the arcellinidan test retention as well as the impact of the selected chemical treatment on arcellinidan tests and population composition. 


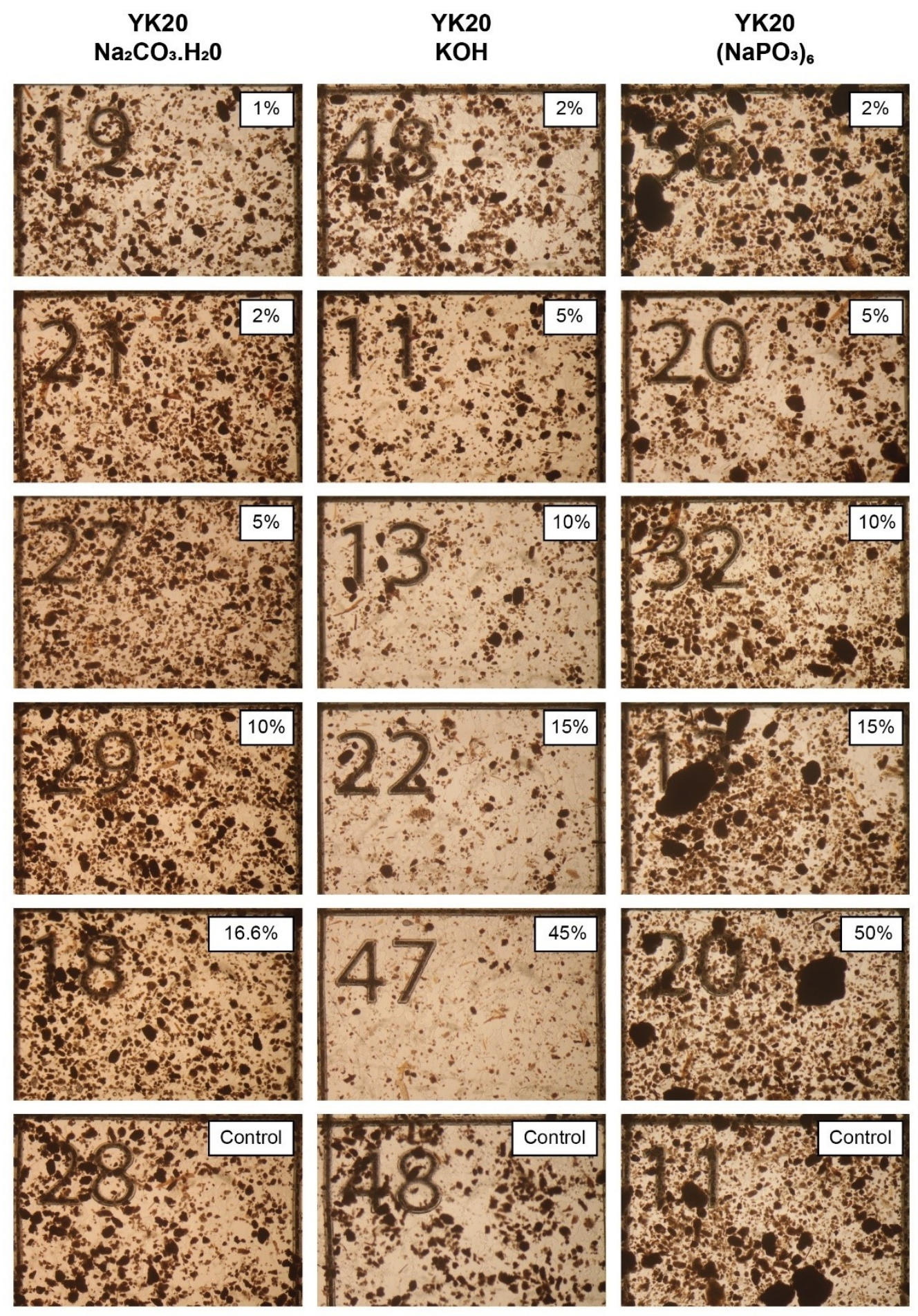

Figure 2. 3: Photomicrographs showing the level of organic content reduction in chemically treated, with different concentrations of soda ash, $\mathrm{KOH}$, and Calgon, and control YK2O sub-samples. 


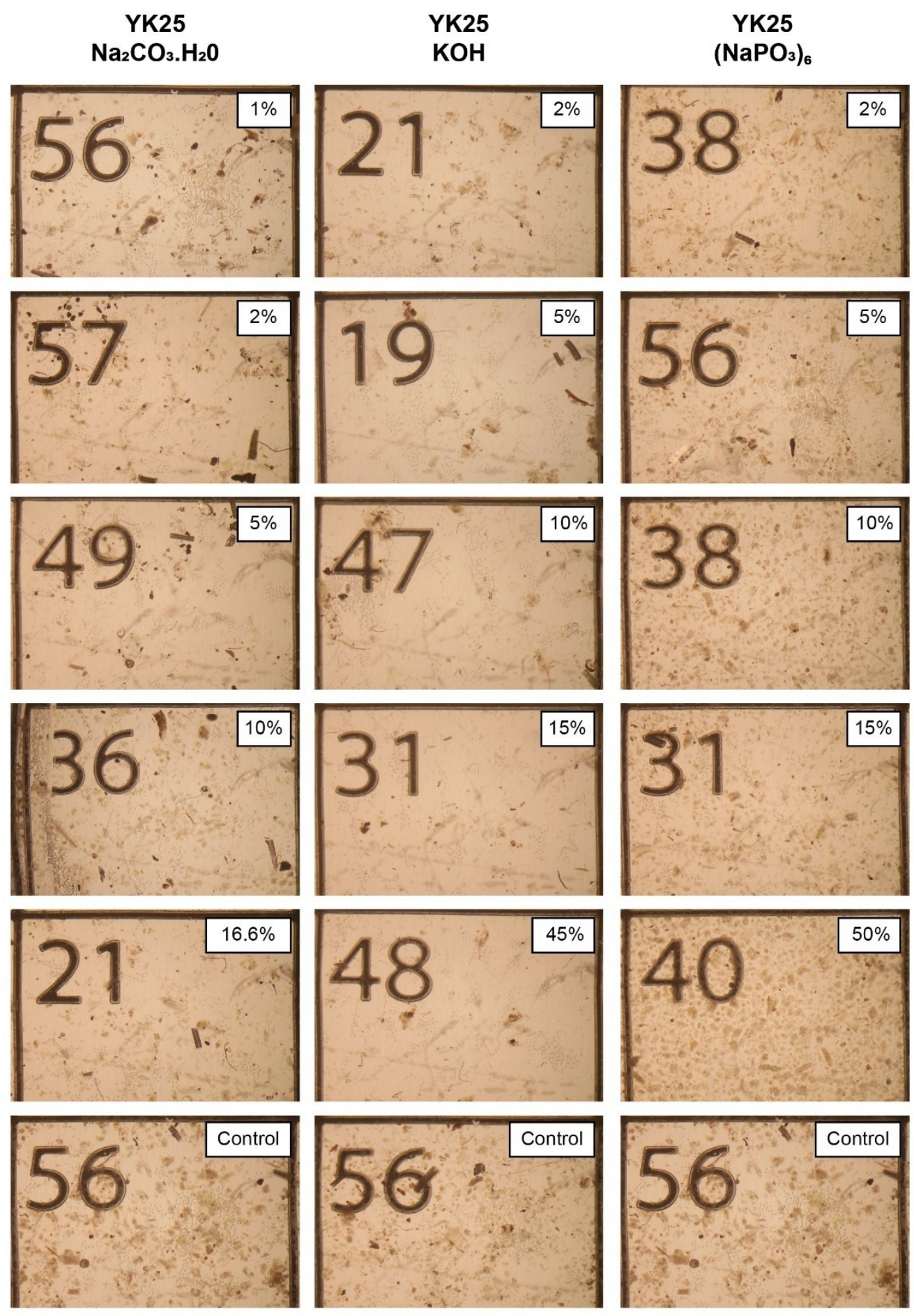

Figure 2. 4: Photomicrographs showing the level of organic content reduction in chemically treated, with different concentrations of soda ash, $\mathrm{KOH}$, and Calgon, and control YK25 sub-samples. 
YK57
$\mathrm{Na}_{2} \mathrm{CO}_{3} \mathrm{H}_{2} \mathrm{O}$
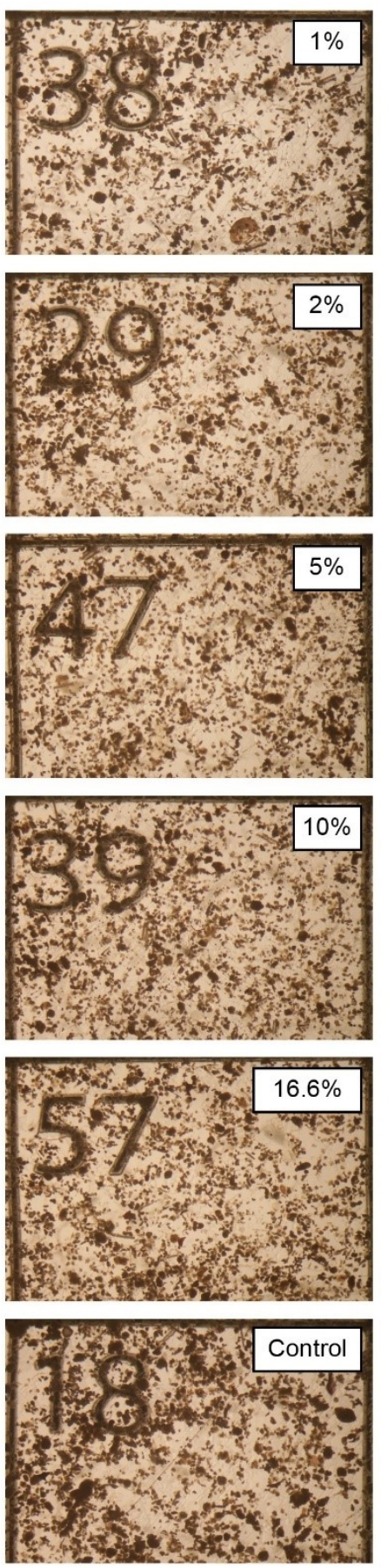

YK57

$\mathrm{KOH}$
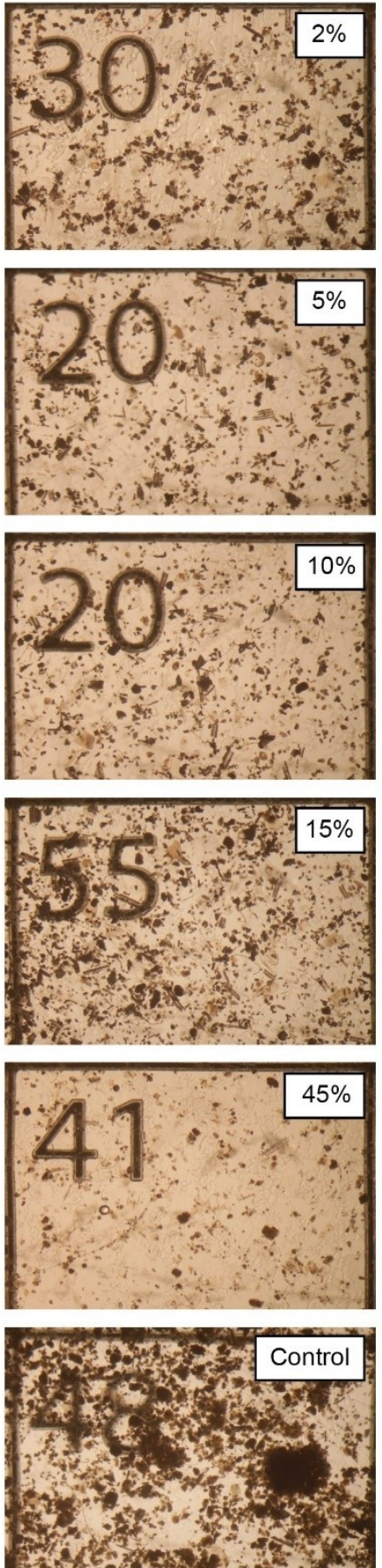

YK57

$\left(\mathrm{NaPO}_{3}\right)_{6}$
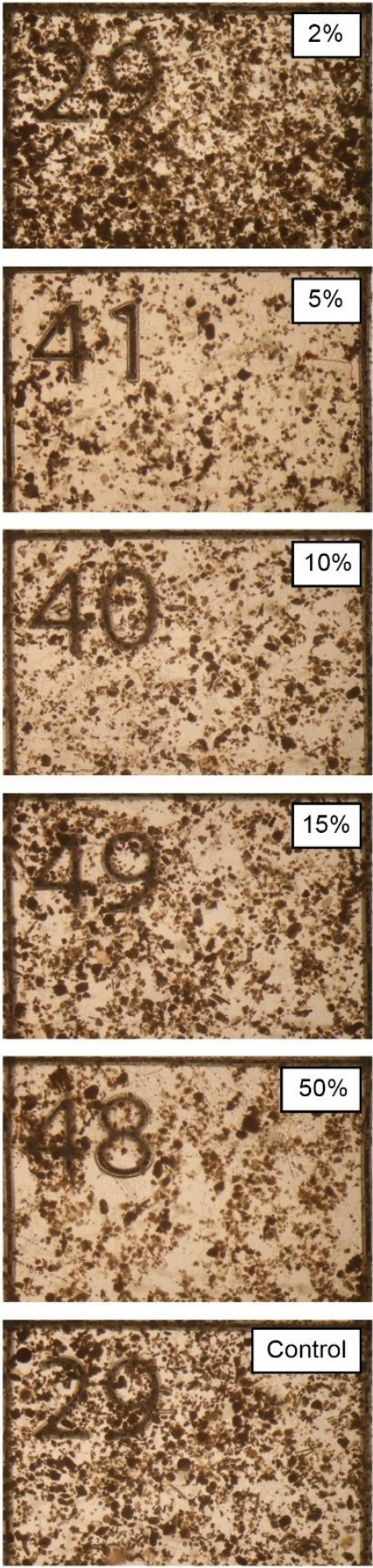

Figure 2. 5: Photomicrographs showing the level of organic content reduction in chemically treated, with different concentrations of soda ash, $\mathrm{KOH}$, and Calgon, and control YK57 sub-samples. 


\subsubsection{Statistical Methods}

Arcellinidan data generated in the third testing stage (Table 2.3) was analyzed using RStudio statistical software (version 0.98.1028; R core team, 2014). Q-mode cluster analysis was performed on the Arcellinida fractional abundance data using the Ward Minimum Variance clustering method (Ward, 1963) to identify any variations in the composition of faunal assemblages resulting from the chemical treatments. The statistical significance of each identified assemblage was determined using the PVClust package (Figure 2.6). The Bray-Curtis Dissimilarity Matrix (BCDM; Bray and Curtis, 1957) of the Arcellinida count data was generated to assess the level of similarity between the samples comprising each assemblage (Supplementary Table 2.1), and thus detect any subtle changes in faunal composition after chemical treatment. Standard error (Sxi) was calculated for each taxon in the treated and control sub-sample using the following equation:

$$
S x i=1.96 \sqrt{\frac{F 1(1-F 1)}{N i}}
$$

where $F 1$ is the fractional abundance of species and $N i$ is the total number of counts. Determining the standard error was important for assessing whether a reduction in organic content via chemical deflocculation is associated with lower standard errors of arcellinidan total counts of dominant, common, and minor taxa (Patterson and Fishbein, 1989; Supplementary Table 2.2). 
Table 2. 3: Raw Arcellinida counts for the control and $5 \% \mathrm{KOH}$ treated subsamples of YK20, YK25, and YK57.

\begin{tabular}{|c|c|c|c|c|c|c|}
\hline \multirow{3}{*}{$\begin{array}{l}\text { Sample } \\
\text { Preparation Method } \\
\text { Sub-sample }\end{array}$} & \multicolumn{6}{|c|}{ YK20 } \\
\hline & \multicolumn{3}{|c|}{ Control } & \multicolumn{3}{|c|}{ Treated } \\
\hline & 1 & 2 & 3 & 4 & 5 & 6 \\
\hline Arcella vulgaris Ehrenberg, 1830 & O & O & 1 & 2 & o & o \\
\hline Centropyxis aculeata (Ehrenberge, 1832) "aculeata" & 33 & 60 & 55 & 88 & 95 & 87 \\
\hline Centropyxis aculeata (Ehrenberge, 1832) "discoides" & 29 & 34 & 33 & 49 & 66 & 97 \\
\hline "aerophila" & 23 & 22 & 33 & 46 & 52 & 46 \\
\hline Centropyxis constricta (Ehrenberg, 1843) & & & & & & \\
\hline "constricta" & 15 & 2 & 12 & 26 & 12 & 17 \\
\hline Centropyxis constricta (Ehrenberg, 1843) "spinosa" & $\mathrm{O}$ & O & o & o & o & o \\
\hline Cucurbitella tricuspis (Carter, 1856) & 5 & 5 & 3 & 13 & 6 & 2 \\
\hline Conicocassis pontigulasiformis (Beyens, Chardez & & & & & & \\
\hline and De Bock, 1986) Nasser and Patterson, 2015 & 16 & 20 & 22 & 35 & 41 & 45 \\
\hline Difflugia globulosa (Dujardin, 1837) Penard 1902 & 23 & 19 & 19 & 15 & 24 & 18 \\
\hline Difflugia amphora Leidy, 1874 & o & $\mathrm{O}$ & 0 & o & $\mathrm{O}$ & o \\
\hline Difflugia glans Penard, 1902 "glans" & 10 & 9 & 17 & 16 & 13 & 7 \\
\hline Difflugia glans Penard, 1902 "distenda" & 8 & 15 & 19 & 17 & 3 & 14 \\
\hline Difflugia spe. & o & o & 2 & o & O & 0 \\
\hline Difflugia lenceolata Penard, 1890 & o & o & o & o & o & o \\
\hline $\begin{array}{l}\text { Difflugia linearis (Penard, 1890) Gauthier \& Lièvre, } \\
1958\end{array}$ & 2 & O & O & O & O & 0 \\
\hline Difflugia oblonga Ehrenberg, 1832 "oblonga" & 32 & 33 & 31 & 23 & 29 & 38 \\
\hline Difflugia oblonga Ehrenberg, 1832 "spinosa" & O & 1 & $\mathrm{O}$ & 1 & 3 & 0 \\
\hline Difflugia oblonga Ehrenberg, 1832 "tenuis" & 6 & 9 & 5 & 2 & 9 & 4 \\
\hline Difflugia protaeiformis Lamarck, 1816 & o & $\mathrm{O}$ & 2 & 2 & $\mathrm{O}$ & o \\
\hline Difflugia acuminata Ehrenberg, 1838 & 3 & 1 & 1 & 1 & 3 & 4 \\
\hline Difflugia claviformis (Penard, 1899) & o & $\mathrm{O}$ & o & o & o & o \\
\hline Difflugia urceolata Carter, 1864 "urceolata" & o & o & o & 4 & 12 & 5 \\
\hline Difflugia urceolata Carter, 1864 "elongata" & o & 1 & o & o & 2 & 4 \\
\hline Difflugia urens Patterson et al., 1985 & o & $\mathrm{O}$ & $\mathrm{O}$ & 9 & 6 & 16 \\
\hline Difflugia curvicaulis Penard, 1899 & o & 1 & $\mathrm{O}$ & o & $\mathrm{O}$ & $\mathrm{O}$ \\
\hline Difflugia elegans Penard, 1890 & 107 & 95 & 101 & 133 & 121 & 116 \\
\hline Difflugia bicornis Penard, 1890 & 0 & 0 & 0 & 1 & 1 & 1 \\
\hline Lagenodifflugia vas (Leidy, 1874) & 10 & 8 & 5 & 6 & 8 & 11 \\
\hline Lesquereusia spiralis (Ehrenberg, 1840) & 4 & 8 & 5 & 3 & 3 & 3 \\
\hline Pontigulasia compressa (Carter, 1864) & 1 & 2 & 3 & 3 & 3 & 3 \\
\hline Total & 327 & 345 & 369 & 495 & 512 & 538 \\
\hline Median & & 347 & & & 512 & \\
\hline Shannon Diversity Index (SDI) & 2.28 & 2.3 & 2.34 & 2.35 & 2.35 & 2.34 \\
\hline Number of Species & 17 & 19 & 19 & 22 & 21 & 20 \\
\hline Total Number of Species & & 21 & & & 23 & \\
\hline Percentage of Increase (total tests count) & & NA & & & $47.55 \%$ & \\
\hline
\end{tabular}


Table 2. 3: Continued.

\begin{tabular}{|c|c|c|c|c|c|c|}
\hline \multirow{3}{*}{$\begin{array}{l}\text { Sample } \\
\text { Preparation Method } \\
\text { Sub-sample }\end{array}$} & \multicolumn{6}{|c|}{ YK25 } \\
\hline & \multicolumn{3}{|c|}{ Control } & \multicolumn{3}{|c|}{ Treated } \\
\hline & $\mathbf{1}$ & 2 & 3 & 4 & 5 & 6 \\
\hline $\begin{array}{l}\text { Arcella vulgaris Ehrenberg, } 1830 \\
\text { Centropyxis aculeata (Ehrenberge, 1832) }\end{array}$ & 0 & 2 & 0 & 1 & 2 & 0 \\
\hline $\begin{array}{l}\text { "aculeata" } \\
\text { Centropyxis aculeata (Ehrenberge, 1832) }\end{array}$ & 20 & 19 & 15 & 24 & 14 & 21 \\
\hline "discoides". & 2 & $\mathrm{o}$ & 1 & 3 & 1 & 6 \\
\hline $\begin{array}{l}\text { Centropyxis constricta (Ehrenberg, 1843) } \\
\text { "aerophila" } \\
\text { Centropyxis constricta (Ehrenberg, 1843) }\end{array}$ & 1 & 1 & 4 & 3 & 1 & 3 \\
\hline $\begin{array}{l}\text { "constricta" } \\
\text { Centropyxis constricta (Ehrenberg, 1843) }\end{array}$ & 11 & 4 & 9 & 4 & 4 & 3 \\
\hline "spinosa" & $\mathrm{O}$ & $\mathrm{o}$ & o & 1 & o & o \\
\hline $\begin{array}{l}\text { Cucurbitella tricuspis (Carter, 1856) } \\
\text { Conicocassis pontigulasiformis (Beyens, }\end{array}$ & 2 & 5 & 3 & $\mathrm{o}$ & 5 & 1 \\
\hline $\begin{array}{l}\text { Chardez and De Bock, 1986) Nasser and } \\
\text { Patterson, 2015 } \\
\text { Difflugia globulosa (Dujardin, 1837) Penard }\end{array}$ & $\mathrm{o}$ & $\mathrm{o}$ & o & $\mathrm{o}$ & 1 & o \\
\hline 1902 & 3 & 1 & o & 0 & 2 & 1 \\
\hline Difflugia amphora Leidy, 1874 & $\mathrm{o}$ & 0 & o & o & o & o \\
\hline Difflugia glans Penard, 1902 "glans" & o & o & 1 & o & 1 & 3 \\
\hline Difflugia glans Penard, 1902 "distenda" & o & 1 & o & o & o & 0 \\
\hline Difflugia spe. & o & 0 & o & o & o & o \\
\hline $\begin{array}{l}\text { Difflugia lenceolata Penard, } 1890 \\
\text { Difflugia linearis (Penard, 1890) Gauthier \& }\end{array}$ & 0 & $\mathrm{o}$ & 0 & 0 & 0 & 0 \\
\hline Lièvre, 1958 & 0 & 0 & 0 & 0 & 0 & o \\
\hline Difflugia oblonga Ehrenberg, 1832 "oblonga" & o & 1 & 1 & o & 1 & o \\
\hline Difflugia oblonga Ehrenberg, 1832 "spinosa" & o & 0 & 0 & o & o & o \\
\hline Difflugia oblonga Ehrenberg, 1832 "tenuis" & 1 & o & 1 & 1 & 1 & 1 \\
\hline Difflugia protaeiformis Lamarck, 1816 & 7 & 12 & 8 & 3 & 9 & 2 \\
\hline Difflugia acuminata Ehrenberg, 1838 & o & 0 & o & 0 & 1 & o \\
\hline Difflugia claviformis (Penard, 1899) & o & o & o & o & 1 & 2 \\
\hline Difflugia urceolata Carter, 1864 "urceolata" & o & o & o & 1 & o & $\mathrm{o}$ \\
\hline Difflugia urceolata Carter, 1864 "elongata" & o & o & o & o & o & o \\
\hline Difflugia urens Patterson et al., 1985 & o & o & o & o & 4 & o \\
\hline Difflugia curvicaulis Penard, 1899 & o & o & o & o & o & 0 \\
\hline Difflugia elegans Penard, 1890 & 29 & 25 & 31 & 45 & 37 & 40 \\
\hline Difflugia bicornis Penard, 1890 & 0 & 0 & o & 0 & 0 & 0 \\
\hline Lagenodifflugia vas (Leidy, 1874) & 1 & 1 & o & o & o & 1 \\
\hline Lesquereusia spiralis (Ehrenberg, 1840) & o & o & o & o & o & o \\
\hline Pontigulasia compressa (Carter, 1864) & o & o & o & 1 & 0 & $\mathrm{o}$ \\
\hline $\begin{array}{l}\text { Total } \\
\text { Median }\end{array}$ & 77 & $\begin{array}{c}72 \\
74\end{array}$ & 74 & 87 & $\begin{array}{l}85 \\
85\end{array}$ & 84 \\
\hline Shannon Diversity Index (SDI) & 1.69 & 1.75 & 1.7 & 1.44 & 1.94 & 1.63 \\
\hline Number of Species & 10 & 11 & 10 & 11 & 16 & 12 \\
\hline Total Number of Species & & 14 & & & 20 & \\
\hline Percentage of Increase (total tests count) & & $\mathrm{NA}$ & & & $14.86 \%$ & \\
\hline
\end{tabular}


Table 2. 3: Continued.

\begin{tabular}{|c|c|c|c|c|c|c|}
\hline Sample & & & & & & \\
\hline Preparation Method & & ontr & & & Treated & \\
\hline Sub-sample & $\mathbf{1}$ & 2 & 3 & 4 & 5 & 6 \\
\hline $\begin{array}{l}\text { Arcella vulgaris Ehrenberg, } 1830 \\
\text { Centropuxis aculeata (Ehrenberge, 1832) }\end{array}$ & 2 & 2 & 1 & 20 & 15 & 19 \\
\hline $\begin{array}{l}\text { "aculeata" } \\
\text { Centropyxis aculeata (Ehrenberge, 1832) }\end{array}$ & 72 & 81 & 98 & 459 & 559 & 534 \\
\hline $\begin{array}{l}\text { "discoides" } \\
\text { Centropyxis constricta (Ehrenberg, 1843) }\end{array}$ & 4 & 9 & 4 & 128 & 109 & 141 \\
\hline $\begin{array}{l}\text { "aerophila" } \\
\text { Centropuxis constricta (Ehrenberg, 1843) }\end{array}$ & 1 & 3 & 1 & 43 & 17 & 13 \\
\hline "constricta" & 5 & 6 & 12 & 62 & 10 & 12 \\
\hline $\begin{array}{l}\text { Centropyxis constricta (Ehrenberg, 1843) } \\
\text { "spinosa" }\end{array}$ & $\mathrm{O}$ & $\mathrm{O}$ & $\mathrm{O}$ & 1 & 2 & 2 \\
\hline Cucurbitella tricuspis (Carter, 1856) & 16 & 20 & 15 & 19 & 15 & 21 \\
\hline $\begin{array}{l}\text { Conicocassis pontigulasiformis (Beyens, } \\
\text { Chardez and De Bock, 1986) Nasser and }\end{array}$ & & & & & & \\
\hline $\begin{array}{l}\text { Patterson, } 2015 \\
\text { Diffluqia qlobulosa (Dujardin, 1837) Penard }\end{array}$ & o & o & $\mathrm{O}$ & $\mathrm{O}$ & O & o \\
\hline 1902 & o & 8 & 5 & 111 & 119 & 137 \\
\hline Difflugia amphora Leidy, 1874 & O & $\mathrm{O}$ & 1 & $\mathrm{O}$ & 0 & $\mathrm{O}$ \\
\hline Difflugia glans Penard, 1902 "glans" & 1 & 1 & 1 & 4 & 4 & 2 \\
\hline Difflugia glans Penard, 1902 "distenda" & o & 1 & o & o & 3 & o \\
\hline Difflugia spe. & o & $\mathrm{O}$ & 1 & $\mathrm{O}$ & O & 1 \\
\hline $\begin{array}{l}\text { Difflugia lenceolata Penard, } 1890 \\
\text { Difflugia linearis (Penard, 1890) Gauthier \& }\end{array}$ & 5 & 4 & 9 & 4 & 2 & 1 \\
\hline Lièvre, 1958 & $\mathrm{O}$ & $\mathrm{O}$ & $\mathrm{O}$ & $\mathrm{O}$ & $\mathrm{O}$ & $\mathrm{O}$ \\
\hline Difflugia oblonga Ehrenberg, 1832 "oblonga" & 5 & 8 & 2 & 1 & 1 & 5 \\
\hline Difflugia oblonga Ehrenberg, 1832 "spinosa" & o & $\mathrm{O}$ & 1 & $\mathrm{O}$ & o & $\mathrm{O}$ \\
\hline Difflugia oblonga Ehrenberg, 1832 "tenuis" & o & $\mathrm{O}$ & $\mathrm{O}$ & $\mathrm{O}$ & 1 & $\mathrm{O}$ \\
\hline Difflugia protaeiformis Lamarck, 1816 & 13 & 5 & 8 & 5 & 11 & 11 \\
\hline Difflugia acuminata Ehrenberg, 1838 & 0 & 6 & 4 & 1 & $\mathrm{O}$ & 2 \\
\hline Difflugia claviformis (Penard, 1899) & o & $\mathrm{O}$ & o & o & $\mathrm{O}$ & o \\
\hline Difflugia urceolata Carter, 1864 "urceolata" & $\mathrm{O}$ & $\mathrm{O}$ & $\mathrm{O}$ & 3 & 7 & 4 \\
\hline Difflugia urceolata Carter, 1864 "elongata" & o & O & 1 & 6 & 3 & 3 \\
\hline Difflugia urens Patterson et al., 1985 & $\mathrm{O}$ & 2 & 1 & 2 & 3 & 3 \\
\hline Difflugia curvicaulis Penard, 1899 & 1 & $\mathrm{O}$ & O & O & $\mathrm{O}$ & $\mathrm{O}$ \\
\hline Difflugia elegans Penard, 1890 & 9 & 8 & 9 & 43 & 27 & 23 \\
\hline Difflugia bicornis Penard, 1890 & o & o & o & 0 & $\mathrm{o}$ & 0 \\
\hline Lagenodifflugia vas (Leidy, 1874) & o & o & $\mathrm{O}$ & $\mathrm{O}$ & o & $\mathrm{O}$ \\
\hline Lesquereusia spiralis (Ehrenberg, 1840) & O & $\mathrm{O}$ & O & O & o & $\mathrm{O}$ \\
\hline Pontigulasia compressa (Carter, 1864) & $\mathrm{O}$ & 1 & $\mathrm{O}$ & $\mathrm{O}$ & $\mathrm{O}$ & $\mathrm{O}$ \\
\hline $\begin{array}{l}\text { Total } \\
\text { Median }\end{array}$ & 134 & $\begin{array}{l}165 \\
165\end{array}$ & 174 & 912 & $\begin{array}{l}908 \\
912\end{array}$ & 934 \\
\hline Shannon Diversity Index (SDI) & 1.64 & 1.91 & 1.73 & 1.67 & 1.39 & 1.45 \\
\hline Number of Species & 12 & 16 & 18 & 17 & 18 & 18 \\
\hline Total Number of Species & & 21 & & & 18 & \\
\hline Percentage of Increase (total tests count) & & NA & & & $452.70 \%$ & \\
\hline
\end{tabular}




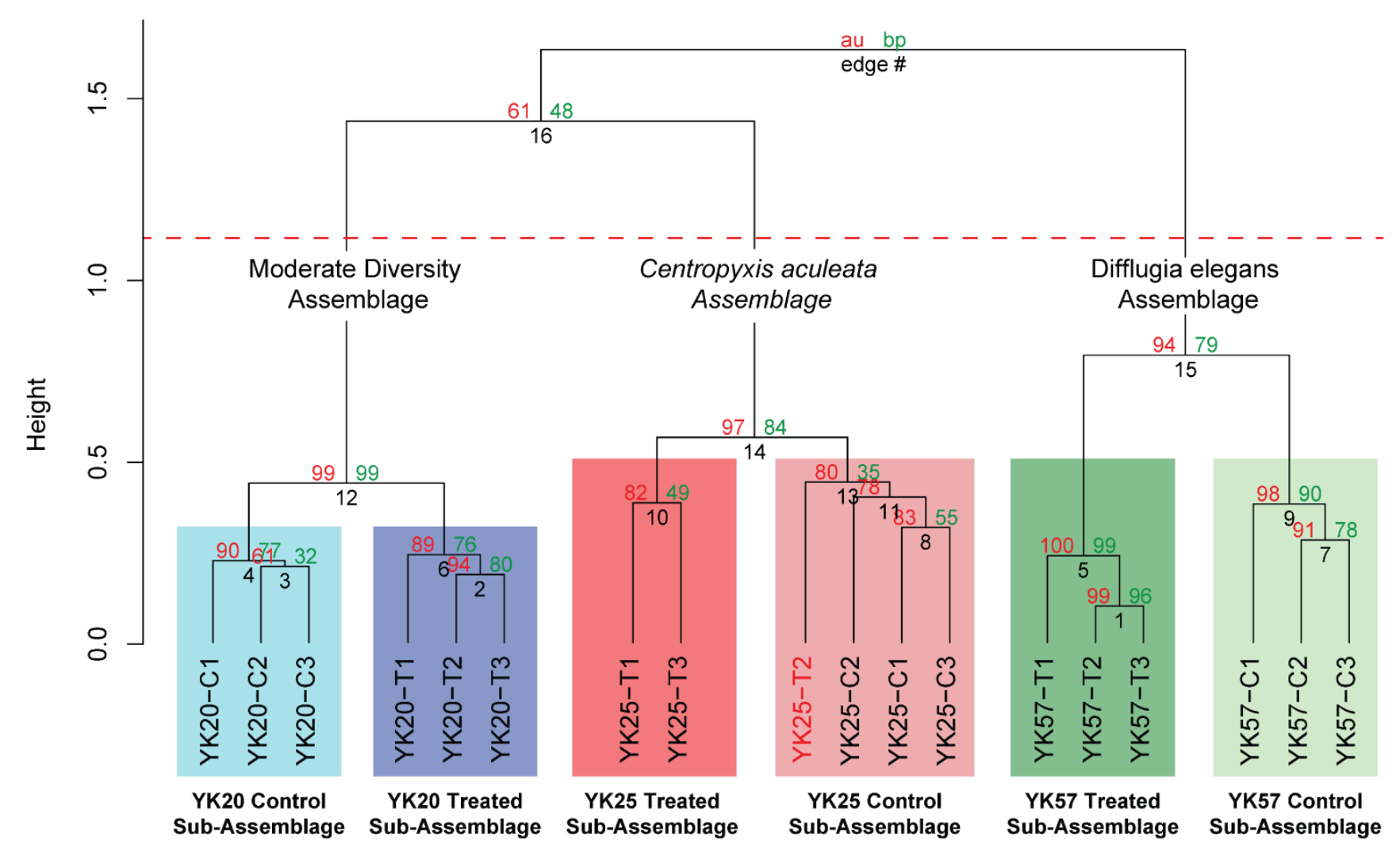

Figure 2. 6: Q-mode cluster analysis dendrogram showing three identified Arcellinida assemblages: 1) Moderate Diversity Assemblage (MDA); 2) Centropyxis aculeata Assemblage (CPA); and, 3) Difflugia elegans Assemblage (DEA). Six faunal sub-assemblages are also indicated with the colored rectangles. The statistical significance of each assemblage and subassemblage was indicated by the results of PVClust (red numbers; $p$-value $<0.05$ ). 


\subsection{Results}

\subsubsection{Chemical methods testing}

\subsubsection{Stage 1-Determining optimal concentrations}

Of the three chemicals used in the experiment, treatment with $\mathrm{KOH}$ showed the greatest reduction in organic content in comparison to the control sub-samples ( $n$ $=3$ ). Higher concentrations of $\mathrm{KOH}$ provided greater reduction in visible organic content, with $45 \%$ concentration providing the greatest reduction, and $2 \%$ still producing a notable decrease in visible organic content. Because the $5 \%, 10 \%$, and $15 \% \mathrm{KOH}$ concentrations provided a similar reduction in visible organic debris as $45 \% \mathrm{KOH}$ exposures, a $5 \% \mathrm{KOH}$ concentration was selected for further testing.

Treatment of aliquots using different concentrations of soda ash (1\%, $2 \%$, $5 \%, 10 \%$, and $16.6 \% ; n=15$ ) showed negligible reduction in visible organic debris except for a meager reduction observed in sub-samples treated with $1 \%$ soda ash (Figures 2.3, Figure 2.4, and Figure 2.5). Therefore, the 1\% soda ash concentration was selected for the next testing stage.

A minor reduction of visible organic content occurred after treatment with sodium hexametaphosphate in comparison to standard sieving treatments $(n=15$; Figures $2.3,2.4,2.5$ ) The $5 \%$ sodium hexametaphosphate concentration was selected for the second testing stage as it reduced slightly higher proportions of organic content compared to the rest of the sodium hexametaphosphate concentrations $(2 \%, 10 \%, 15 \%$, and $50 \%)$. 


\subsubsection{Stage 2 - Determining optimal exposure times}

Treatment of organic-rich samples with $\mathrm{KOH}$ provided a significant reduction in organic content for all exposure times ( 2 minutes, 10 minutes, 30 minutes, 1 hour, 2 hours, and 3 hours; Figure 2.2C). Samples treated for longer durations (1 hour, 2 hours, and 3 hours) exhibited greater reduction in visible organic content, with the three-hour treatment exhibiting the highest reductions in organic content. Exposure to the chemical for $>24$ hours did not further reduce organic matter substantially. The removal of organic content when sodium hexametaphosphate and soda ash were used did not differ substantially over time and remained similar in both the treated and control sub-samples when visually inspected under a dissecting microscope.

In terms of damage/dissolution to arcellinidan tests, treatment with sodium hexametaphosphate caused severe damage to Arcellinida tests, most of which were agglutinated, with signs of damage (e.g. test breakage) manifesting after only two hours of low concentrations treatment ( $2 \%$ and $5 \%)$ and after 45 minutes when higher concentrations were used (10-50\%). Samples treated with soda ash exhibited no discernable signs of damage after 24 hours of treatment in lower concentrations (1-2\%) and after 3 hours in higher concentrations (516.6\%). However, a peculiar side-effect of the treatment was that tests, particularly those of pyriform and globular morphologies, became more elastic the longer the treatment lasted. These tests eventually became easier to break. This change in test robustness was only detected when the test condition was carefully examined using a microscope probe. Severe arcellinidan test damage 
caused by $\mathrm{KOH}$ treatment was observed after 1 day for the $2 \%$ concentration and after 3 hours for the $5 \%$ concentration. However, the tests were damaged after 1 hour when higher concentrations are used (10-45\%). Damage caused by lower concentrations did not impede the identification of Arcellinida tests. Therefore, treatment with $5 \% \mathrm{KOH}$ for three hours was selected as the most efficient chemical treatment method for reducing organic content and was further tested in the third stage.

\subsubsection{Stage 3 - Comparison of treated and untreated sample}

\section{counts}

The control subsamples of YK2O have a median total arcellinidan count of 347 (range $=327-369)$ and a total identified species of 21 (Table 2.3; Figureo 2.7). It was possible in the treated subsamples to increase the total counted arcellinidan tests to a median of 512 tests and a range of $495-538$ (Table 2.3; Figure 2.7). The total arcellinidan test counts in the treated and control splits of sample YK25 only differed slightly with a median of 74 and 85 , and a range of $72-77$, and $84-87$, respectively. However, the number of identified species differed notably, with 14 identified in the control splits, and 20 in the treated splits (Table 2.3; Figure 2.7). Subsamples of YK57 showed a significant ( $p$-value $<0.0001 ; n=6$ ) disparity in the total tests counted for control and treated subsamples. Control aliquots yielded a median total test count of 165 (range $=134-174)$, while treated aliquots yielded a significantly higher median of 908 (range $=908-912)$ (Table 2.3; Figure 2.7). Surprisingly, the number of species identified in the treated splits $(n=19)$ was 
slightly less than that identified in the control splits $(n=21)$. This small decline in species richness in the treated aliquots is likely attributes low abundance of the missing taxa, even in the control aliquots, rather than damage caused by the chemical treatment because damaged remains of the missing species was not observed in the treated aliquots.

\subsubsection{Identified Arcellinida assemblages}

Interpretation of the Q-mode cluster analysis, supplemented with PVClust results, led to the identification of three distinct arcellinidan assemblages that corresponded well with the three analyzed surface sediment samples: 1) Moderate Diversity Assemblage (MD; statistical significance $=99 \%$; $p$-value $<0.05) ; 2$ ) Difflugia elegans Assemblage (DE; statistical significance = 97\%; $p$-value $<0.05$ ); and, 3) Centropyxis aculeata Assemblage (CA; statistical significance = 94\%; $p$ value < 0.05) (Figure 2.6). Based on the PVClust and Bray-Curtis results, each assemblage was further divided into two sub-assemblages: 1) Moderate Diversity Control sub-assemblage (MDC; statistical significance $=90 \%$; $p$-value $<0.05$ ); 2) Moderate Diversity Treated sub-assemblage (MST; statistical significance $=89 \%$; $p$-value < 0.05) ; 3) Difflugia elegans Control sub-assemblage (DEC; statistical significance $=80 \%$; $p$-value $<0.05) ; 4)$ Difflugia elegans Treated sub-assemblage (DET; statistical significance $=82 \% ; p$-value $<0.05) ; 5)$ Centropyxis aculeata Control sub-assemblage (CAC; statistical significance $=98 \%$; $p$-value $<0.05)$; and, 6) Centropyxis aculeata Treated sub-assemblage (CAT; statistical significance $=$ 100\%; $p$-value < 0.05) (Figure 2.6). A single outlier (YK25-Treated 3) is observed 


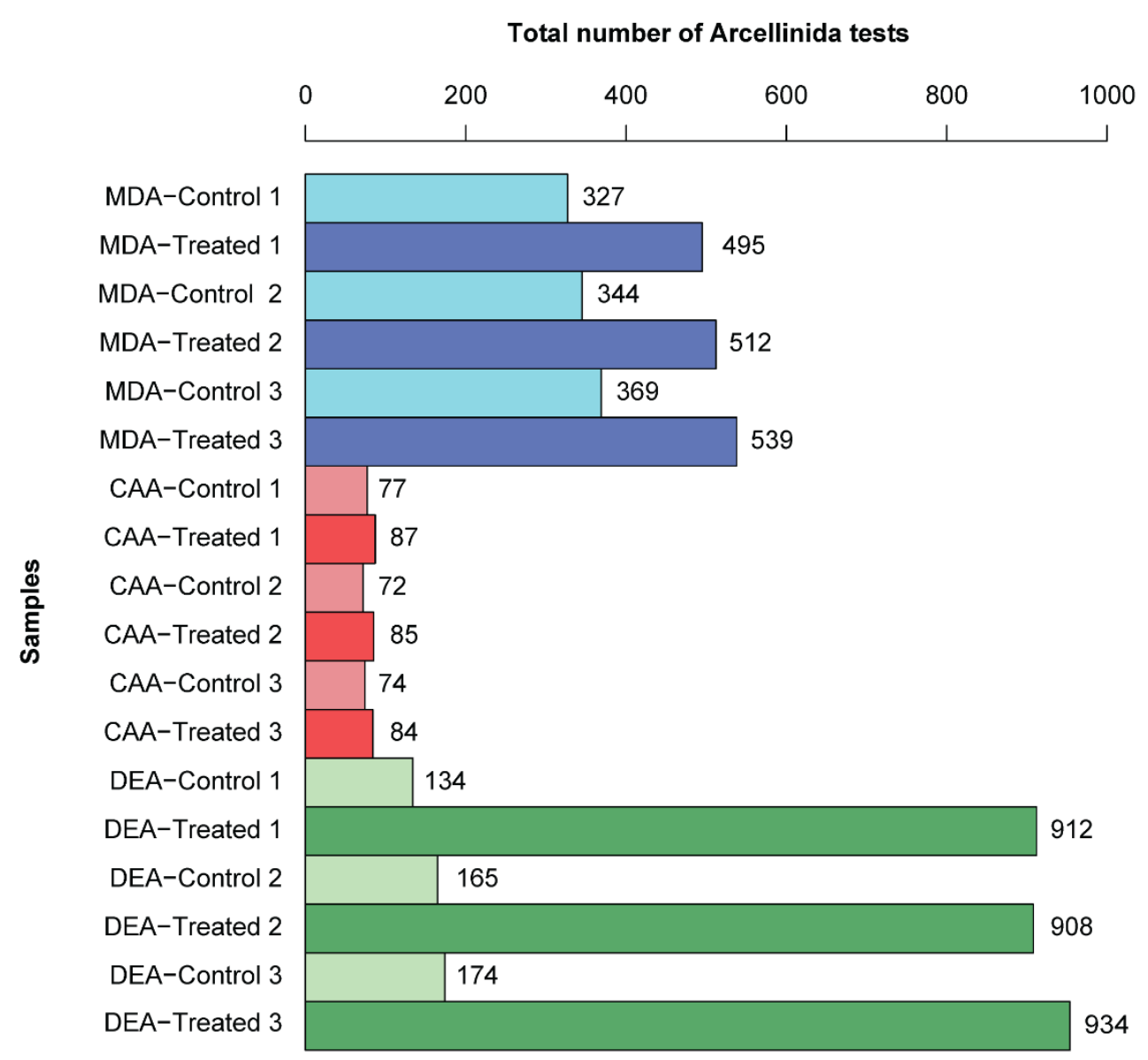

Figure 2. 7: A histogram plot showing the total number of Arcellinida tests ( $\mathrm{x}$-axis) retained in all $5 \% \mathrm{KOH}$ treated and control sub-samples (y-axis). The different colours reflect the identified assemblages and sub-assemblages. MDA Moderate Diversity Assemblage; CAA - Centropyxis aculeata Assemblage; DEA - Difflugia elegans Assemblage. 
plotting with the samples of the DEC sub-assemblage, when it should be plotting with DET.

\subsubsection{Moderate diversity assemblage (MD)}

The MD assemblage was found only in the YK2O aliquots $(n=6)$ (Figure 6). The faunal composition of the assemblage is co-dominated by Difflugia elegans Penard, 1890 (median proportion $=27.1 \%)$ and Centropyxis aculeata $($ Ehrenberg, 1832) strain "aculeata" (median proportion $=16.8 \%)($ Table 3$)$. Other taxa like $C$. aculeata (Ehrenberg, 1832) strain "discoides" (median proportion $=9.9 \% ; n=6$ ), C. constricta (Ehrenberg, 1843) strain "aerophila" (median proportion $=8.7 \% ; n$ = 6), D. oblonga Ehrenberg, 1832 strain “oblonga" (median proportion $=7.7 \% ; n$ =6), Conicocassis pontigulasiformis (Beyens, Chardez and De Bock, 1986) Nasser and Patterson, 2015 (median proportion $=6.5 \% ; n=6$ ), and D. globulosa (Dujardin, 1837) Penard 1902 (median proportion $=4.6 \% ; n=6$ ) are commonly present in all aliquots (Table 2.3). The sediment composition of MD samples is dominated by the silt fraction (76.82\%; Table 2). Faunal diversity of MD is moderate with the calculated Shannon Diversity Index (SDI) values falling in the range of 2.28-2.35 (Magurran, 1988) (Table 2.1).

The MDC and MDT sub-assemblages share a relatively similar faunal structure, with $D$. elegans being the dominant taxa (median proportion $=27.5 \%$ and $23.6 \%$ in MDC and MDT, respectively). However, the sub-assemblages differed in the proportions of $D$. oblonga "oblonga: (MDC median proportions = 9.6\%; MDT median proportions $=7.7 \%$ ) and $C$. constricta "aerophila" (MDC 
median proportions $=7 \%$; MDT median proportions $=9.6 \%$ ). Additionally, the total number of species identified increased slightly in MDT $(n=23)$ compared to MDC ( $n=21)$ (Table 2.3). A single species, Difflugia curvicaulis Penard, 1899, was only present in MDC, while D. urceolata Carter, 1864 stain “urceolata”, D. urens Patterson et al., 1985, and D. bicornis Penard, 1890 were only present in MDT. Total arcellinidan counts in treated samples were associated with lower median standard error values with a percentage of reduction ranging between 0.5450.10\% $(n=3)$ (Supplementary Table 2.2). Only one taxon (D. acuminata) exhibited a notable increase in median standard error (median Sxi increase $\%=$ $16.5 ; n=3)$.

Results of the BCDM showed that the faunal structure of the MD assemblage differed notably from that of the $\mathrm{DE}$ (median dissimilarity coefficient $=0.43$ ) and CA assemblages (median dissimilarity coefficient $=0.59$ ). The results also showed that while the dissimilarity coefficients for the two MD subassemblages is notably low (median $=0.144 ; n=36$ ), MDT subsamples were characterized by a slightly higher median (o.12) when compared to samples of MDC (median dissimilarity coefficient $=0.09$ ).

\subsubsection{Difflugia elegans assemblage (DE)}

The DE assemblage was found exclusively in YK25 subsamples (Figure 2.6). Similar to the MD assemblage, both $D$. elegans (median proportion $=42.7 \% ; n=$ 6), and C. aculeata "aculeata" (median proportion $=25.5 \% ; n=6$ ) dominated the arcellinidan population in the DE assemblage. Notable numbers of $D$. 
protaeiformis Lamarck, 1816 strain "protaeiformis" (median proportion $=7 \% ; n=$ 6) and C. constricta "constricta" (median proportion $=5.1 \% ; n=6$ ) are also present in most DE samples. Samples of DE were collected from a silt-dominated substrate (71.19\%; Table 2.2). The SDI range calculated for the assemblage (1.44-1.94) was reflective of relatively poor faunal diversity (Magurran, 1988).

The faunal composition of the DEC and DET sub-assemblages was relatively similar, except for small but notable differences in the abundance of the dominating taxa, with DEC samples having higher numbers of C. aculeata "aculeata" (median proportion $=25.5 \% ; n=3$ ) compared to DET (median proportion $=22 \% ; n=3$ ), and DET samples having slightly higher proportions of D. elegans (median proportion $=47.6 \% ; n=3$ ) in comparison to DEC (median proportion $=39.8 \% ; n=3$ ). The number of species Identified notably increased from 14 in the DEC samples to 20 in the DET samples. Additionally, D. glans Penard 1902 strain "distenda" were only present in the control samples, while $C$. pontigulasiformis, D. acuminata Ehrenberg, 1838, D. urceolata "urceolata", D. urens, and Pontigulasia compressa (Carter, 1864) were only present in the treated aliquots. Similar to the MDA, counted arcellinidan taxa were associated with relatively low median standard error values (median reduction \% range $=2.24-$ 48.3\%; $n=3$ ) (Supplementary Table 2.2). Two taxa, C. constricta "aerophila" (median Sxi increase $\%=41.8 ; n=3$ ) and C. aculeata "discoides" (median Sxi increase $\%=45.7 ; n=3$ ) exhibited a notable increase in median standard error.

The BCDM results showed that samples of the DE assemblage differed from that of MD (median dissimilarity coefficient $=0.43$ ) and CA assemblages (median dissimilarity coefficient $=0.55$ ). The median dissimilarity coefficient for the DEC 
and DET (0.21) was low, indicating a high level of similarity between the faunal assemblage seen in the DE sub-assemblages.

\subsubsection{Centropyxis aculeata assemblage (CA)}

The CA assemblage was found in YK57 subsamples. Unlike the previous two assemblages, the faunal composition of the CA assemblage was dominated by $C$. aculeata "aculeata" (median proportion $=57 \% ; n=6$ ). Species like $C$. aculeata strain "discoides" (median proportion $=14 \% ; n=6$ ) and D. globulosa (median proportion $=13.1 \% ; n=6$ ) are also present in elevated numbers. Similar to MD and DE, sample of CA samples were collected from a silty substrate (77.43\%; Table 2.2). The SDI values for the assemblages are between 1.39-1.91 and are reflective of relatively poor faunal diversity of the assemblage (Magurran, 1988).

Centropyxis aculeata "aculeata" dominated the faunal structure of the CAC $($ median proportion $=57.3 \% ; n=3)$ and CAT $($ median proportion $=53.7 \% ; n=3)$. However, higher numbers of Cucurbitella tricuspis (Carter, 1856) (median proportion $=11.9 \% ; n=3)$ and $D$. elegans $($ median proportion $=5.2 \% ; n=3)$ characterized samples of CAC, while $C$. aculeata "discoides" (median proportion = $14 \% ; n=3$ ) and D. globulosa (median proportion $=13.1 \% ; n=3$ ) were more abundant in the CAT samples. A small decline in the number of identified species was observed in the CAT samples $(n=18)$ compared to the CAC samples $(n=21)$. Four arcellinidan taxa, namely D. amphora Penard 1902, Difflugia sp., D. oblonga Ehrenberg 1838 strain "spinosa", and D. curvicaulis are only present in the CAC samples, while D. oblonga "oblong' was only present in the CAT samples. Total 
counts of Arcellinida taxa were associated with notably reduced median standard error values in the treated aliquots (median reduction \% range $=0.379-93.2 \% ; n$ = 3) (Supplementary Table 2.2).

Similar to the previous assemblages, the BCDM results revealed that the faunal structure of CAC differed notably from that of MD (median dissimilarity coefficient $=0.59)$ and $\mathrm{DE}$ (median dissimilarity coefficient $=0.55$ ). While the dissimilarity coefficients for the CAC and CAT sub-assemblages is notably low (median $=0.21 ; n=36$ ), CAT sub-samples are characterized by notably lower median dissimilarity coefficient (o.06) when compared to the CAC sub-samples (median $=0.29)$.

\subsection{Discussion}

\subsubsection{Reduction of organic content using chemical treatment}

Previous lake arcellinidan and peatland testate amoebae studies have reported a reduction in the organic content in samples treated with soda ash (Burbidge and Schroder-Adams, 1998), sodium hexametaphosphate (Ellison and Ogden, 1985; McCarthy et al., 2012), or KOH (Hendon and Charman, 1997; Charman et al., 2010; Farooqui et al., 2012). Our results show that the three tested chemical treatment methods removed varying proportions of organic content depending on the type of chemical used, its concentration and the duration of treatment. Organic-content removal was highest in subsamples treated with $\mathrm{KOH}$, varying to inconsequentially small amounts in sodium hexametaphosphate and soda ash- 
treated subsamples (Figure 2.3; Figure 2.4; Figure 2.5). The substantial reduction of organic content in the $\mathrm{KOH}$-treated subsamples is consistent with the findings of other testate amoebae and Arcellinida studies (Hendon and Charman, 1997; Charman et al., 2010; Farooqui et al. 2012). Our results also reveal an increase in organic content reduction with increase in $\mathrm{KOH}$ concentration. In contrast, the meager reduction of organic content in soda ash- and sodium hexametaphosphatetreated sub-samples is surprising, especially since multiple studies have reported notable reductions in organic content in sample treated with sodium hexametaphosphate (e.g. Ellison and Ogden, 1985; McCarthy et al., 2012) and soda ash (e.g. Burbidge and Schröder-Adams, 1998). The sodium hexametaphosphateand soda ash-treatments are less effective than $\mathrm{KOH}$ in deflocculating the organic colloidal particles, and in turn reducing the organic content in lake sediments.

\subsubsection{Damage to Arcellinida tests}

While various chemical treatment methods have typically been used in the preparation of palynological and microfaunal samples, such methods have been infrequently used in peatland testate amoebae and, to an even lesser extent, lake arcellinidan studies due to the potential for destruction of tests. Our results show that all three tested chemical treatment protocols resulted in damage to arcellinidan tests, but the degree of damage depended on the type of chemical, the concentration used and the duration of exposure to the treatment. Test damage caused by the treatment methods was not exclusive to a certain tests type (i.e. secreted vs. agglutinated), taxon, or a set of species and strains of Arcellinida. 
The rapid severe damage to tests caused by sodium hexametaphosphate treatment was surprising, since previous studies that have employed different concentrations of sodium hexametaphosphate $(6 \%-10 \%$; Ellison and Ogden, 1985; McCarthy et al., 2012) reported insignificant, or no damage to arcellinidan tests even after treating samples for long periods of time (e.g. 12 hours; Ellison and Ogden, 1985). More surprising, and concerning, is the nature of damage induced by the soda ash treatment method. The peculiar side-effect of the treatment described above -more elastic tests resulting from longer chemical exposuremay only be detected through examining test robustness with a microscope probe. This form of test damage has not previously been reported (e.g. 30-minute treatment; Burbidge and Schroder-Adams, 1998) or even after several weeks of continuous soda ash treatment (Dalby, 2002).

Treatment using $\mathrm{KOH}$ led to varying degrees of test damage. Hendon and Charman (1997) found that treating peatland samples with $10 \% \mathrm{KOH}$ led to the identification of more Arcellinida tests but caused enough damage to hinder statistical analysis of arcellinidans in some samples. Conversely, Charman et al. (2010) reported notably enhanced arcellinidan analysis and significantly lower test damage when samples were treated with $5 \% \mathrm{KOH}$ instead. Our results corroborated the findings of Charman et al. (2010) and showed that test damage caused by the $2 \%$ and $5 \% \mathrm{KOH}$ concentrations was not severe enough to hamper test identification and enumeration. However, Farooqui et al. (2012) reported notable test damage in samples treated with $5 \% \mathrm{KOH}$, even though the arcellinidan population in treated samples was found to be relatively abundant and diverse. The samples were initially treated in $5 \% \mathrm{KOH}$ and later aceytolyzed with acetic acid. In 
their study to test different testate amoebae sample preparation methods, Hendon and Charman (1997) found that acetylation was the most damaging of all evaluated

methods including treatment using $\mathrm{KOH}$. This suggests that test loss reported by Farooqui et al. (2012) may be attributed to the adverse effects of acetylation rather than treatment with $\mathrm{KOH}$.

\subsubsection{Arcellinidan test retention and faunal composition}

Testing of the selected chemical treatments on the three samples demonstrates that chemical treatment is beneficial in samples with high organic content. Comparing treated and untreated sample aliquots demonstrated that treatment liberated a significant proportion of tests from organic colloidal content. These tests would otherwise be undetected when the samples were prepared with the standard methods.

The results of the third testing stage revealed that $5 \% \mathrm{KOH}$ treatment enhanced arcellinidan test identification and enumeration by reducing significant amounts of organic debris without causing severe damage to arcellinidan tests. This improvement in analysis quality was reflected in a notable increase in the total arcellinidan tests identified in the treated subsamples, with an elevated increase in YK20 subsamples (median increase percentage $=47.5 \%$ ) and a more drastic increase in YK57 subsamples (median increase percentage $=452.7 \%$; Figure 2.7, Table 2.3). Similar findings have been reported in studies that observed notable reductions of organic content and elevated number of tests identified in $\mathrm{KOH}-$ treated samples (e.g. Hendon and Charman, 1997; Farooqui et al., 2012; Charman 
et al., 2010). The disparity between the total test counts in control and $\mathrm{KOH}-$ treated subsamples confirmed that a considerable number of tests may be trapped or concealed by residual organic content when the standard sample preparation method is employed. Interestingly, the total number of tests identified in the treated subsamples of YK25 increased slightly (median increase percentage $=$ 14.8\%; Figure 2.7, Table 2.3). This small increase in test retention is expected and is attributed to the thin coverage of organic detritus in the YK25 subsamples (Figure 2.3; Figure 2.4; Figure 2.5). These results suggest that chemical treatment may only be necessary for samples characterized by dense organic content (e.g. YK20 and YK57).

The three identified assemblages represented the three analyzed samples and were characterized by a relatively consistent faunal structure (Figure 2.6, Table 2.3, Supplementary Table 2.1). Similarly, sub-assemblages identified in this study shared a relatively consistent arcellinidan composition, differing only in the concentrations of the dominant arcellinidan taxa, and uncommon taxa $(<5 \%$ relative abundance). These results are consistent with the findings of Charman et al. (2010) who observed relatively consistent faunal structure for the arcellinidan population identified in $5 \% \mathrm{KOH}$-treated samples. This consistency in the faunal compositions of the identified assemblages and sub-assemblages suggests that the chemical treatment is not differentially impacting the faunal structure of arcellinidan assemblage in general, or certain arcellinidan taxa in particular. Additionally, the notable reduction in the median standard error (Sxi) for most total arcellinidan taxa counts in the treated samples suggest an enhanced efficiency 
of the arcellinidan analysis (Supplementary Table 2.2).

\subsection{Conclusions}

We assessed the impact of three chemical deflocculation methods (soda ash $\left(\mathrm{Na}_{2} \mathrm{CO}_{3} \cdot \mathrm{H}_{2} \mathrm{O}\right)$, potassium hydroxide $(\mathrm{KOH})$, or sodium hexametaphosphate $\left(\left(\mathrm{NaPO}_{3}\right)_{6}\right)$ on organic content reduction and destruction of arcellinidan tests in three lacustrine sediment samples. Of the three tested chemical methods, treatment with $5 \% \mathrm{KOH}$ was the most effective in reducing considerable proportions of organic content, which led to the identification and enumeration of much higher numbers of arcellinidan tests.

However, improvement of the total number of arcellinidan tests retained was more subtle in samples characterized by reduced organic concentrations to start with, indicating that chemical treatment is generally only necessary in samples where both TOC is elevated (e.g., TOC > 20\%) and the observed organic content density is high when visually assessed under a dissecting microscope. The $5 \% \mathrm{KOH}$ treatment caused acceptable levels of damage that was neither exclusive to certain arcellinidan taxa nor severe enough to hamper arcellinidan analysis. The arcellinidan assemblages and sub-assemblages identified in $5 \% \mathrm{KOH}$-treated and control sub-samples were characterized by relatively consistent faunal compositions, indicating that chemical treatment is not severely impacting the faunal composition of the identified assemblages. However, the aggressive nature 
of $\mathrm{KOH}$ treatment, even at lower concentrations, must be taken into consideration when samples characterized by fragile or damaged tests are analysed.

\subsection{Acknowledgments}

Funding for this research project was provided by a NSERC Discovery Grant to RTP as well as a NSERC Strategic Project Grant, a Department of Aboriginal and Northern Affairs Cumulative Impact Monitoring Program grant, and a Polar Knowledge grant awarded to JMG and RTP. This project was also supported by the Geological Survey of Canada, Environmental Geoscience Program (JMG). Additional direct and in-kind funding was provided by the Northwest Territories Geological Survey and Natural Resources Canada Polar Continental Shelf Program. Funding was also provided by Loeblich and Tappan Student Research Award (NAN).

\subsection{References}

Charman DJ, 2001. Biostratigraphic and palaeoenvironmental applications of testate amoebae. Quaternary Science Reviews 2o(16-17):1753-1764.

Patterson RT, Kumar A, 2002. A review of current testate rhizopod (thecamoebian) research in Canada. Palaeogeogr Palaeoclimatol Palaeoecol $180(1-3): 225-251$. 
Scott DB, Medioli FS, 1983. Testate rhizopods in Lake Erie: modern distribution and stratigraphic implications. Journal of Paleontoloy 57:809-820.

Patterson RT, MacKinnon KD, Scott DB, Medioli FS, 1985. Arcellaceans (Thecamoebians) in small lakes of New Brunswick and Nova Scotia: modern distribution and Holocene stratigraphic changes. Journal of Foraminiferal Research 15:114-137.

Medioli FS, Scott DB, 1988. Lacustrine thecamoebians (mainly arcellaceans) as potential tools for palaeolimnological interpretations. Palaeogeography, Palaeoclimatology, Palaeoecology 62(1-4):361-386.

Scott DB, Hermelin, JOR, 1993. A device for precision splitting of micropaleontological samples in liquid suspension. Journal of Paleontology $67: 151-154$.

Elmgren R, 1973. Method of sampling sublittoral soft bottom meiofauna. Oikos 15:112-120.

Payne R, 2009. The standard preparation method for testate amoebae leads to selective loss of the smallest shells. Quaternary Newsletter 119:16-20.

Avel E, Pensa M, 2013. Preparation of testate amoebae samples affects water table depth reconstructions in peatland palaeoecological studies. Estonian Journal of Earth Science 62:113-119.

Wall AAJ, Gilbert D, Magny M, Mitchell EAD, 2010. Testate amoeba analysis of lake sediments: Impact of filter size and total count on estimates of density, 
species richness and assemblage structure. Journal of Paleolimnology 43(4):689-704.

Mazei Y, Chernyshov V, Tsyganov AN, Payne RJ, 2015. Testing the Effect of Refrigerated Storage on Testate Amoeba Samples. Microbial Ecology 70(4): $861-864$.

Collins ES, McCarthy FM, Medioli FS, Scott DB, Honig CA, 1990. Biogeographic distribution of modern thecamoebians in a transect along the eastern North American coast. In: Hemleben C, Kaminski MA, Kuhnt W, Scott DB (Eds.), Paleoecology, Biostratigraphy, Paleoceanography and Taxonomy of Agglutinated Foraminifera. NATOAdvanced Study Institute Series, Series C, Mathematical and Physical Sciences 327:783-791

Peter K, Bent B, Ole VO, John N, 2001. Chironomid stratigraphy in the shallow and eutrophic Lake Søbygaard, Denmark: chironomid-macrophyte cooccurrence. Freshwater Biology 253-267.

Brooks SJ, 2000. Late-glacial fossil midge stratigraphies (Insecta: Diptera: Chironomidae) from the Swiss Alps. Palaeogeography, Palaeoclimatology, Palaeoecology 159(3-4): 261-279.

Barker S, Greaves M, Elderfield H, 2003. A study of cleaning procedures used for foraminiferal $\mathrm{Mg} / \mathrm{Ca}$ pale- othermometry, Geochemistry, Geophysics, Geosystems 4(9):8407. 
Feldmeijer W, Metcalfe B, Scussolini P, Arthur K (2013) The effect of chemical pretreatment of sediment upon foraminiferal-based proxies. Geochem Geophys Geosyst 14(10):3996-4014. https://doi.org/10.1002/ggge.20233

Hendon D, Charman DJ, 1997. The preparation of testate amoebae (Protozoa: Rhizopoda) samples from peat. Holocene 7(2):199-205.

Ellison RL, Ogden CG, 1987. A Guide to the Study and Identification of Fossil Testate Amoebae in Quaternary Lake Sediments. Internationale Revue Der Gesamten Hydrobiologie Und Hydrographie 72(5), 639-652.

Burbidge SM, Schröder-Adams CJ, 1998. Thecamoebians in Lake Winnipeg: A tool for holocene paleolimnology. Journal of Paleolimnology 19(3):309-328.

McCarthy F, Tiffin S, Sarvis A, McAndrews J, Blasco S, 2012. Early Holocene brackish closed basin conditions in Georgian Bay, Ontario, Canada: microfossil (thecamoebian and pollen) evidence. Journal of Paleolimnology 47(3):429-445.

Kerr DE, Wilson P, 2000. Preliminary surficial geology studies and mineral exploration considerations in the Yellowknife area, Northwest Territories. Geological Survey of Canada Current Research C3, p 8;

Environment Canada, 2019. National Climate Data and Information Archive, Canadian Climate Normals or Averages 1981-2010, Yellowknife A, Northwest Territories; Environment Canada, <http://www.climate.weatheroffice.gc.ca> [accessed March 10, 2019]. 
Nasser NA, Patterson RT, Galloway JM, Roe HM, Neville LA, Macumber AL, Sanei H, Patterson RT, Palmer MJ, Spence C, 2016. Lacustrine Arcellinina (Testate Amoebae) as Bioindicators of Arsenic Contamination. Microbial Ecology 72(1):130-149.

Core Team R, 2014. R: A Language and Environment for Statistical Computing. Available at: http://www.r-project.org (accessed 1oth, October, 2018).

Ward JH, 1963. Hierarchical grouping to optimize an objective function. Journal of the American Statistical Association 58:236-244

Bray JR, Curtis JT, 1957. An ordination of the upland forest communities of southern Wisconsin. Ecology Monographs 27:325-349.

Penard E (1890) Etudes sur les rhizopodes d'eau douce. Memoires de la Société de physique et d'histoire naturelle de Genève 31:1-230.

Ehrenberg CG, 1832. Über die Entwicklung und Lebensdauer der Infusionsthiere, nebst ferneren Beitra"gen zu einer Vergleichung ihrer organischen Systeme. Königliche Akademie der Wissenschaften zu Berlin Physikalische Abhandlungen 1931:1-154.

Ehrenberg CG, 1843. Verbreitung und Einfluss des mikroskopischen Lebens in Su"d-und Nord Amerika: Ko"nigliche Akademie der Wissenschaften zu Berlin Physikalische Abhandlungen 1841:291-446.

Nasser NA, Patterson RT, 2015. Conicocassis, a new genus of Arcellinina (testate lobose amoebae). Palaeontologia Electronica 18:1-11. 
Magurran AE, 1988. Ecological diversity and its measurement. Princeton University Press, Princeton, $185 \mathrm{pp}$.

Carter HJ, 1864. On freshwater Rhizopoda of England and India. The Annals and Magazine of Natural History 13:18-39.

Lamarck JB, 1816. Histoire Naturelle des Animaux sans Vèrtèbres. Verdièie, Paris, tome 2, p. 1-568.

Penard E, 1902. Faune Rhizopodique du Bassin du Lèman. Henry Kündig, Libraire de L’institut, Genéve pp 712.

Charman DJ, Gehrels WR, Manning C, Sharma C, 2010. Reconstruction of recent sea-level change using testate amoebae. Quaternary Research 73(02):208219.

Farooqui A, Kumar A, Swindles GT, 2012. Thecamoebian communities as proxies of seasonality in Lake Sadatal in the Ganga-Yamuna Plains of North India. Palaeontologia Electronica 15(1):1-19. 


\section{Chapter 3}

\section{Inter-Annual Arcellinida (testate lobose amoebae) Assemblage Dynamics within Lacustrine Environments}

Nawaf A. Nasser ${ }^{1}$, Jaclyn Cullen${ }^{1}$, Calder W. Paterson¹, R. Timothy Patterson ${ }^{1}$, Helen M. Roe², Jennifer M. Galloway ${ }^{2,3}$

${ }^{1}$ Department of Earth Sciences, Carleton University, Ottawa, Ontario, Canada $\mathrm{K} 1 \mathrm{~S} 5 \mathrm{~B} 6$

${ }^{2}$ School of Natural and Built Environments, Queen's University, Belfast, United Kingdom BT7 1NN

3 Geological Survey of Canada / Commission géologique du Canada - Calgary, Alberta, Canada T2L 2A7 


\subsection{Abstract}

Arcellinida (testate lobose amoebae) were examined from 22 surface-sediment samples collected from homogenous environments in eastern Canadian lakes (Lac du Castor Blanc, SW Quebec; Oromocto Lake, SW New Brunswick) to: 1) evaluate the faunal consistency of assemblages within the targeted environments; and, 2) assess the Arcellinida assemblage response evident in samples collected from Oromocto Lake in $2010 \mathrm{CE}(n=10)$ and $2012 \mathrm{CE}(n=6)$ to inter-annual changes in environmental conditions. Cluster analysis and detrended correspondence analysis (DCA), redundancy analysis (RDA), and Bray-Curtis Dissimilarity Matrix (BCDM) were used to identify the dominant arcellinidan assemblages, determine physicochemical controls over the Arcellinida distribution, and assess the assemblages' faunal homogeneity, respectively. Cluster analysis, DCA, and BCDM results revealed two distinct and relatively homogenous arcellinidan assemblages: 1) Lac du Castor Blanc Assemblage; and 2) Oromocto Lake Assemblage, which could further be subdivided into Oromocto Lake 2010 (OL10), and 2012 (OL12) sub-assemblages. RDA results showed that $65.6 \%$ of the variance in the arcellinidan distribution could be attributed to four significant parameters; sand size fraction (32.1\%), calcium (29.2\%), manganese (2.7\%), and organic content (1.5\%). The OL10 and OL12 sub-assemblages aligned well with the respective sample collection dates of $2010 \mathrm{CE}$ and $2012 \mathrm{CE}$, with proportions of the healthylake-indicating Diffluggiid taxa being higher in OL12, likely due to a concurrent slight increase in substrate organic content in the $2012 \mathrm{CE}$ sediments. Our results confirm the faunal homogeneity of assemblages in limnologically similar 
environments, and demonstrate the rapid response of Arcellinida assemblages to changes in lake conditions at inter-annual time scales.

Keywords: Lakes, homogenous environments, Arcellinida, assemblage dynamics, inter-annual change, multivariate statistics

\subsection{Introduction}

Arcellinida, also known as testate lobose amoebae (Mitchell et al., 2008), or as thecamoebians (Patterson and Kumar, 2002), are a group of shelled benthic protozoans that inhabit most terrestrial freshwater aquatic environments (Medioli and Scott, 1988; Patterson and Kumar 2002). The geographical distribution of Arcellinida is wide, extending from the tropics (Dalby et al., 2000; Farooqui and Gaur, 2006) to the Arctic region (Collins et al., 1990; Beyens and Chardez, 1995). Within this extensive geographical range the group is primarily found in freshwater lakes, rivers, ponds, and wetlands (Patterson and Kumar, 2002; Neville et al., 2010; Schwind et al., 2016) and, to a lesser extent, brackish water habitats (Patterson et al., 1985; Charman et al., 2000). Arcellinida are distinguished by a test (shell) ranging in size from 5 to $500 \mu \mathrm{m}$ and are either autogenous (i.e. secreted by the organism) or xenogenous (i.e. constructed by the process of agglutinating materials like sand grains and diatom frustules), with the latter being of greater use in limnological and paleolimnological studies (Patterson and Kumar, 2002). While Arcellinida are most abundant in Holocene terrestrial aquatic deposits, their 
fossil record extends throughout the Phanerozoic (öFoissner and Schiller, 2001; van Hengstum et al., 2007) and into the Late Neoproterozoic (Porter and Knoll, 2000)

The number of studies investigating the reliability of Arcellinida as proxy for variability in lacustrine environmental conditions has been steadily growing for the past few decades (e.g., Patterson et al. 1985, Asioli et al., 1996; Reinhardt et al., 1998; Neville et al., 2010; Patterson et al., 2013; Steel et al., 2017; Gavel et al., 2018). This increased interest in Arcellinida is attributed to: 1) their abundance in lacustrine substrates (500-3000 tests/ml; Patterson and Kumar, 2002); 2) their fast reproduction rates (few days to a week); 3) the durability of their tests, which enhances their preservation potential; 4) the relative ease of taxonomic identification compared to other lacustrine microfaunal groups (e.g. diatoms); and, 5) their sensitivity to a wide range of environmental parameters. These attributes make Arcellinida an ideal tool for monitoring environmental change, human-made or otherwise, in lakes. Recent arcellinidan studies have focused on quantifying the relationship between Arcellinida community (i.e. assemblages) dynamics and variations in many physicochemical parameters, like lake acidity (Kumar and Patterson, 2000), pH variability (Patterson et al., 2013), nutrient loading (Patterson et al., 2012), water quality (Roe et al., 2010), land-use changes (Patterson et al., 2002), road salt contamination (Roe \& Patterson, 2014) and metal mining contamination (e.g., Asioli et al., 1996; Kihlman and Kauppila, 2009; Nasser et al., 2016). Most of these studies focused on assessing the response of the group to contemporary (i.e. spatial) or the long-term temporal impact of 
environmental variability. While the body of literature on lacustrine Arcellinida continues to grow, a gap remains in our understanding of the relationships between the dynamics of Arcellinida assemblages and short-term environmental trends in lakes.

The structure of microfaunal communities is in a state of constant change, mainly due to the influences of variations in biotic and abiotic factors in the environment (Brown et al., 2001). Environmental variability can occur over short(seasonal and annual) to longer-time scales (subdecadal to thousands of years). Identifying the response of a microfaunal community (e.g. Arcellinida) to shorttime scale changes is particularly imperative for accurately determining: 1) environmental preferences of certain taxa; 2) species and assemblage distributional patterns in different lake ecosystems; and, 3) primary drivers of variability in community structure (Levin, 1992; Thrust et al., 1997). While the sensitivity of testate amoebae assemblages to annual environmental changes has been frequently assessed in mediums like soil (Smith, 1973; Coûteaux, 1976; Laminger et al., 1980; Lousier, 1984), peatlands (Mazei and Tsyganov, 2007), rivers (Schwind et al., 2016) and ponds (Roe \& Patterson, 2006; Neville et al., 2010), similar assessments in lacustrine environments are currently limited (Laminger, 1971; Schönborn, 1992; Foissner, 1994; Kumar and Patterson, 2000; Farooqui et al., 2010; Dividova and Vasilev, 2013).

In this experiment, Arcellinida were examined from 22 surface sediment samples collected from comparable limnological environments (e.g. similar substrates and water depth) in eastern Canadian lakes Lac du Castor Blanc (SW Quebec) and Oromocto Lake (SW New Brunswick), to: 1) evaluate the consistency 
of the faunal compositions of Arcellinida assemblages found within the targeted homogenous environments; and, 2) assess the dynamics of arcellinidan assemblages in response to inter-annual limnological changes in samples collected from Oromocto Lake in $2010 \mathrm{CE}(n=10)$ and $2012 \mathrm{CE}(n=6)$. Results from this study provide new insight into the sensitivity of Arcellinida to short-term environmental changes, which is critical for confirming the reliability of utilizing the group as a tool for monitoring subtle trends of lacustrine environmental change.

\subsection{Study Area}

\subsubsection{Lac du Castor Blanc}

Lac du Castor Blanc $\left(46.145726^{\circ},-76.037677^{\circ}\right)$ is located in SW Quebec, approximately $90 \mathrm{~km}$ north of Ottawa in the Outaouais region (Figure 3.1B). The region is geologically part of the Grenville Super group characterised by Archean or Early Proterozoic metamorphic rocks hosting stratified zinc and iron deposits (Brown 1982; Gauthier and Brown, 1986). The study area receives an average of $939.9 \mathrm{~mm}$ precipitation annually and is characterized by an annual temperature of $4.7^{\circ} \mathrm{C}$ (Environment Canada, 2018). Areas of tall, high-density coniferous trees fringe the perimeter of the lake, with lower-density patches deciduous trees occurring further away from the lake shore.

Lac du Castor Blanc is relatively small in size (Area $=152.2 \mathrm{ha})$ and has an elongated and relatively meandering morphology stretching for $3.7 \mathrm{~km}$ in the 


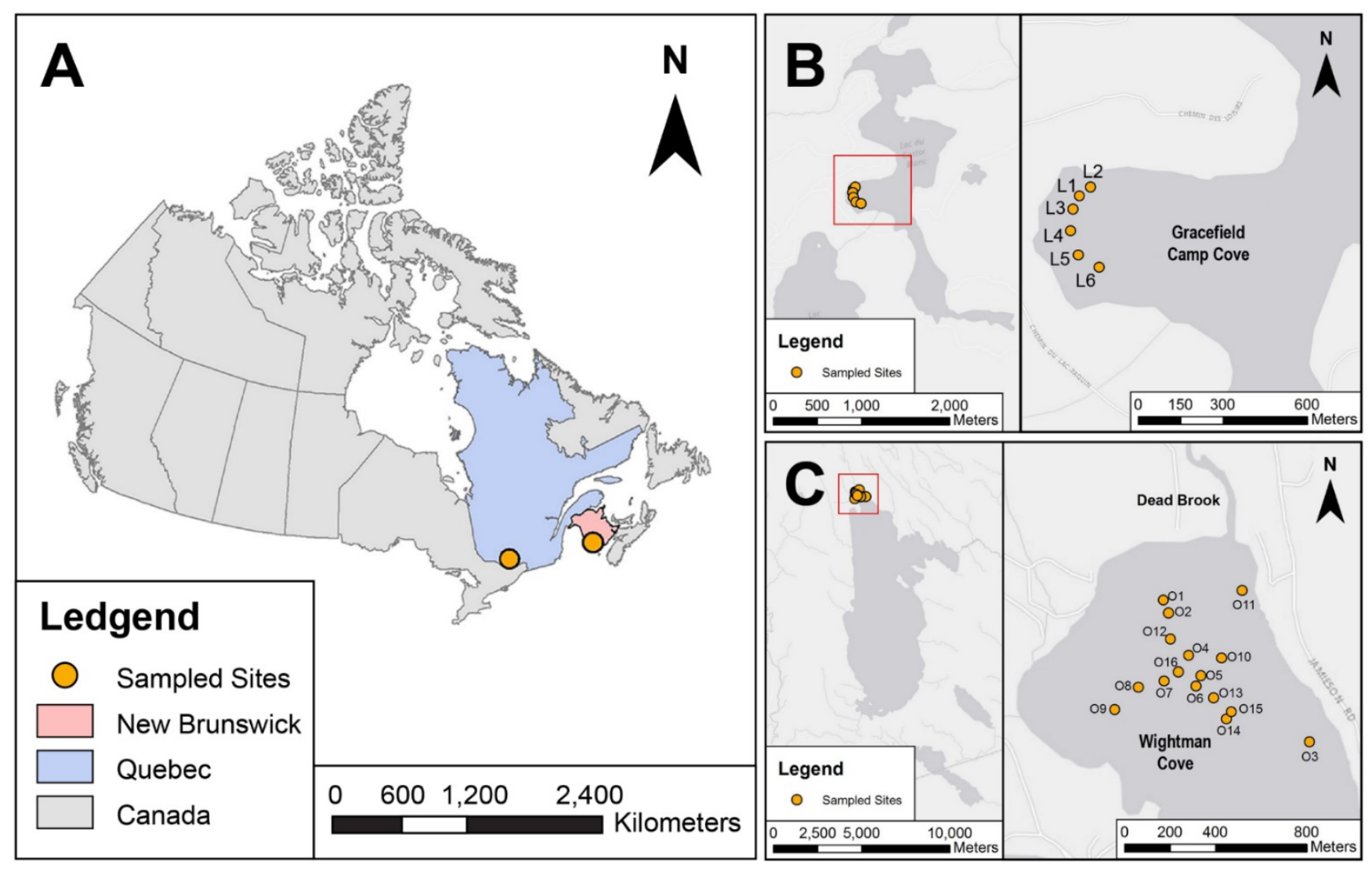

Figure 3. 1: Map of the study areas. A) map of Canada showing the sampled lakes (yellow circles) in Quebec (light blue highlight) and New Brunswick (Light red highlight). B) A map showing the sampled sites (yellow circles) in Gracefield Camp Cove (red square), Lac du Castor Blanc, Quebec, Canada. C) A map showing the sampled sites (yellow circles) in Wightman Cove (red square), Oromocto Lake, New Brunswick, Canada. 
north-south direction (Figure 3.1B). The lake is situated $174 \mathrm{~m}$ above sea level, with a river from Lac à Webb draining into its northern basin. Bathymetric information for the lake is currently limited and is exclusive to the central western basin, informally referred to as Gracefield Camp Cove below, which is characterizing by a water depth ranging from $1.5 \mathrm{~m}$ to a maximum depth of $10.5 \mathrm{~m}$ (Supplementary Table 3.1). Human development of the area began in $1840 \mathrm{CE}$ when Irish settlers formed a settlement called Gracefield south of the lake (Commission de toponymie, Quebec, 2015). A mica mine opened in $1896 \mathrm{CE}$ and was in operation until the $1908 \mathrm{CE}$ (Sabina, 1970). The lake has many cottages along the southern shoreline, as well as the large Gracefield Christian Camp and Retreat Centre, adjacent to Gracefield Camp Cove.

\subsubsection{Oromocto Lake}

Oromocto Lake $\left(45.642225^{\circ},-66.997384^{\circ}\right)$ occurs in SW New Brunswick, in Tweedside, a rural region within the greater Harvey area (Figure 3.1C). The lake is situated in the Saint John River Valley/Highland Foothills (Pronk and Allard, 2003). This region has been significantly modified by glacial and melt-water processes and is characterized by moderate relief and sand and gravel deposits forming eskers, kames and outwash deltas (Pronk \& Allard, 2003). Oromocto Lake is at an elevation of $20.7 \mathrm{~m}$ above mean sea level. The only sizeable lake inlet is

Dead Brook, a small stream that drains into Wightman Cove at the north end of the lake. The average precipitation for the study area is $1077 \mathrm{~mm} / \mathrm{year}$, and an average annual temperature is $5.6^{\circ} \mathrm{C}$ (Environment Canada, 2018). The vegetation 
cover around the lake consists of coniferous, broadleaf and mixed wood trees (Hanson, 2013).

Oromocto Lake is elongated and widens gradually toward the southern end (Figure 3.1C). The northeastern section of the lake forms an arm that protrudes and tapers eastward. There are two main basins in the open water area, a small northern sub-basin (water depth $=8.9 \mathrm{~m})$, and a bigger and deeper $(13.5 \mathrm{~m}$ ) southern basin (Hanson, 2014). Samples collected for this study were from Wightman Cove, which is flat-bottomed and covered by 2-5 $\mathrm{m}$ of soft sediment (Steel et al. 2018). There are a large number of cottages and year-round homes found within Wightman Cove and elsewhere along the western margin of the lake.

\subsection{Materials and Methods}

\subsubsection{Sampling Design and Field Work}

Sixteen surface-sediment samples were collected from stations in Wightman Cove, Oromocto Lake over two field seasons in $2010 \mathrm{CE}(n=10)$ and $2012 \mathrm{CE}(n=6)$ to determine if arcellinidan assemblages varied in response to subtle inter-annual changes in environmental conditions (Figure 3.1C). Substrates characterized by relatively uniform environmental conditions (e.g. similar water depth and sedimentary composition) were sampled as they are often represented by arcellinidan assemblages with a relatively consistent faunal structure (Steele et al. 2018). This was a critical component of this experiment as relative homogeneity within both limnological conditions and the associated arcellinidan assemblage structure is required to ensure that any identified changes in Arcellinida 
assemblage dynamics can be attributed to short-term environmental variability rather than differences in the sampled environment (e.g. littoral vs. open water environments). Following the same site selection criteria used for Oromocto Lake, six surface-sediment samples were collected from the limnologically similar Gracefield Camp Cove of Lac du Castor Blanc, Quebec in 2010 CE as an outgroup against which to assess the homogeneity and consistency of arcellinidan assemblages found in Oromocto Lake.

Sample sites were selected using a Lowrance Elit-4x fish finder (depth uncertainty $= \pm 0.6 \mathrm{~m}$ ) equipped with a bottom hardness indicator, which allowed for identification of muddy substrates where higher proportions of Arcellinida often dwell (Patterson and Kumar, 2002). The geographical locations of sampled sites in both lakes were determined using a Garmin GPSMPA 76Cx GPS unit (Supplementary Table 3.1). Water column environmental parameters data (e.g., dissolved oxygen [DO], $\mathrm{pH}$, conductivity, and water temperature) were recorded in each lake basin, in the deepest sites, at $1 \mathrm{~m}$ intervals using a YSI Multi-parameter instrument equipped with quatro cables (Supplementary Table 3.1). Both lakes

were accessible by road and samples were collected from a small boat using a standard Ekman grab sampler. The top $0.5 \mathrm{~cm}$ of sediment from each grab, where living arcellinidan populations are often found, was retained for analysis.

\section{3•3.2 Laboratory Analyses}

Geochemical, sedimentological and micropaleontological analyses were carried out on sub-samples. The geochemical composition of the material was determined using inductively coupled mass spectrometry (ICP-MS: 1F/AQ250 
package) following aqua regia digestion at Bureau Veritas, Vancouver (Supplementary Table 3.1). Aqua regia digestion was chosen to only capture the concentration of heavy metals and metalloids that can potentially be bioavailable (Nasser et al., 2016; Santoro et al., 2017).

Loss-on-ignition (LOI) analysis was carried out following Heiri et al. (2001) on sub-samples to estimate the percentage of organic, carbonate, and minerogenic content in the sediment (Supplementary Table 3.1). Wet sediment subsamples (1 cc) were placed in weighed ceramic crucibles, which were subsequently placed in an oven over night $\left(70 \mathrm{C}^{\circ}\right)$ to dry. A programmable Fisher Scientific Muffle furnace was then used for the sequential burning of the dried sub-samples at $500^{\circ} \mathrm{C}$ and $950^{\circ} \mathrm{C}$ in order to calculate the percentage of organic matter and carbonate content in each sample, respectively. Data generated by LOI can provide valuable information on sediment sources, surface processes such as erosion and lake productivity (Huang et al., 2004).

Subsamples were prepared for particle size analysis (PSA) by digesting subsamples in a heated bath $\left(70 \mathrm{C}^{\circ}\right)$ with $10 \% \mathrm{HCl}$ and $30 \% \mathrm{H}_{2} \mathrm{O}_{2}$ to remove carbonate and organic content, respectively (Murray 2002, van Hengstum et al., 2007). Following digestion, sedimentary grain size in each sub-sample was analyzed using a Beckman Coulter LS13 320 laser diffraction analyzer fitted with a universal liquid medium (ULM) sample chamber over a measurement range between 0.4 and 200olm. Samples were loaded into the instrument until an obscuration level of $10 \pm 3 \%$ was attained. GRADISTAT (Version 8 ) (Blott and Pye, 2001) was used to compile the results (Supplementary Table 3.1). Garnet15 (mean diameter $15 \mu \mathrm{m}: \pm$ $2 \mu \mathrm{m}$ ), an accuracy standard supplied by Beckman Coulter, was run once per 
month. An in-house mud sample (Cushendun Mud) was run at the start of every session as a precision control.

Arcellinida analysis was carried out on all sub-samples. Five $\mathrm{cm}^{3}$ of wet sediments were sieved through $297 \mu \mathrm{m}$ and $37 \mu \mathrm{m}$ to remove coarse and fine organic and mineral debris and retain arcellinidan tests. The samples were then split into six aliquots using a wet splitter (Scott and Hermelin, 1993) and examined wet in a gridded Petri Dish. Arcellinida species and strains in each sub-sample were identified and enumerated using an Olympus SZH dissecting binocular microscope at magnifications ranging between 20-50x until counts of a statistically significant number (at least 250 where possible) were obtained following Patterson and Fishbein (1989) (Supplementary Table 3.2). Arcellinida were identified using photomicrographs from the existing literature that utilize the 'strain' intrasubspecific taxonomic concept (Reinhardt et al. 1998; Roe et al., 2010; Patterson et al., 2012; Patterson et al., 2013; Nasser et al., 2016; Steele et al., 2018; Gavel et al., 2018) (Supplementary Table 3.2). Scanning electron microscope (SEM) images of common Arcellinida species and strains were obtained using a Tescan Vega-II XMU VP SEM at Carleton University. All plates were digitally produced using Adobe Photoshop ${ }^{\mathrm{TM}}$ (CC6) (Figure 3.2, Figure 3.3).

\subsubsection{Statistical Analyses}

The probable error (pe) was calculated for each sample using the following formula:

$$
\text { pe }=1.96\left(\frac{s}{\sqrt{X_{i}}}\right)
$$




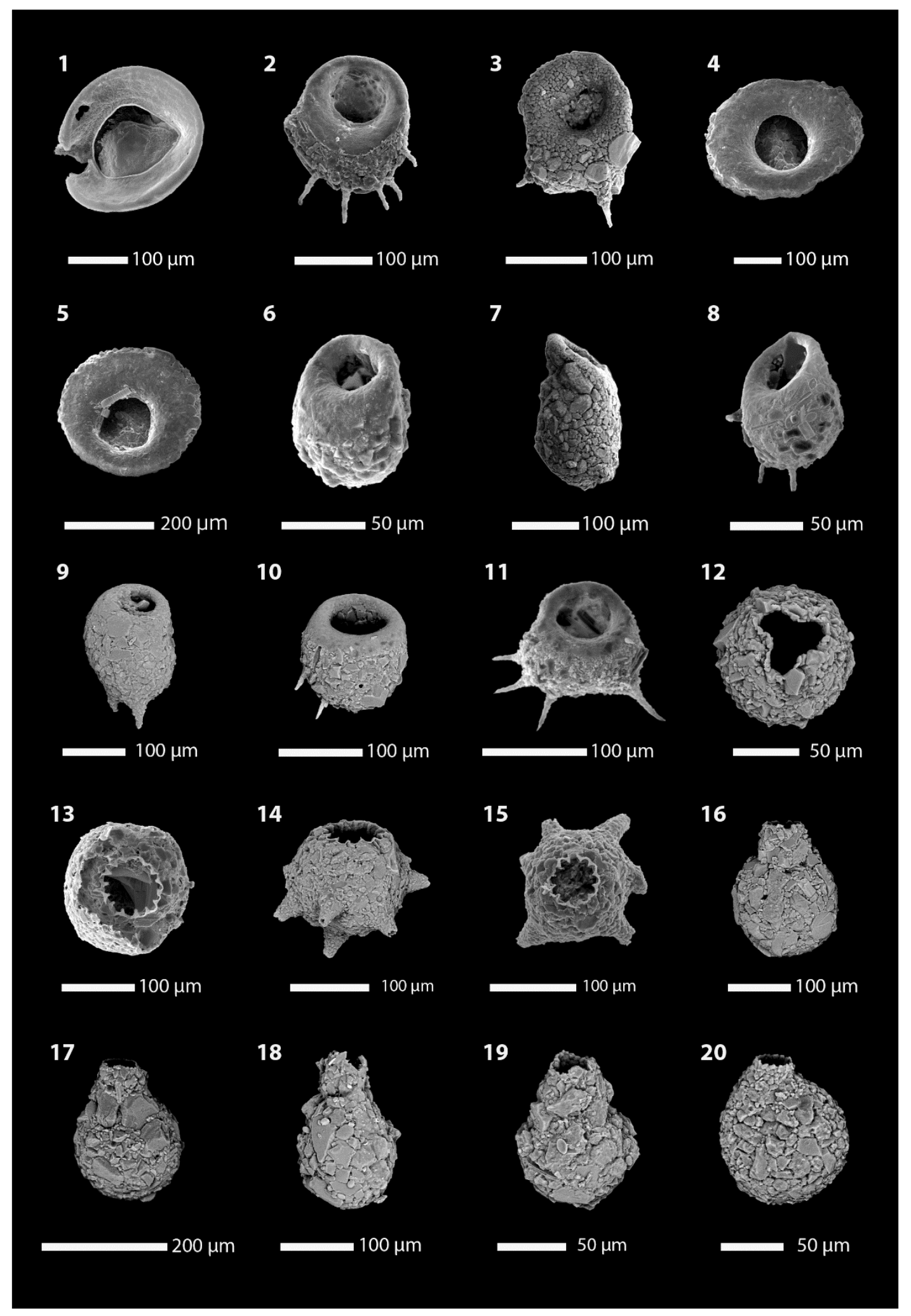


Figure 3. 2: Arcellinida from Lac du Castor Blanc and Oromocto Lake. 1 Arcella vulgaris Ehrenberg 1830. 2-3 Centropyxis aculeata (Ehrenberg 1832) stain "aculeata". 4-5 Centropyxis aculeata (Ehrenberg 1832) stain "discoides". 6-7 Centropyxis constricta (Ehrenberg 1843) stain "aerophila". 8-10 Centropyxis constricta (Ehrenberg 1843) stain "constricta". 11 Centropyxis constricta (Ehrenberg 1843) stain "spinosa". 12 Cucurbitella tricuspis (Carter 1856). 13-15 Mediolus corona (Wallich 1986). 16-17 Pontigulasia compressa (Carter 1864). 1819 Lagenodifflugia vas (Leidy 1874). 20 Lesquereusia spiralis (Ehrenberg 1840). 


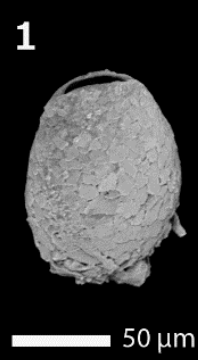

5

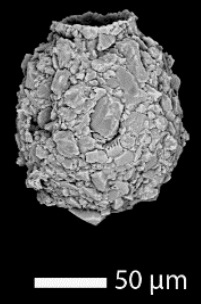

9

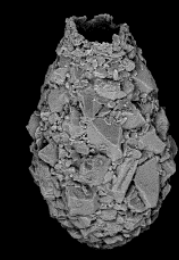

$100 \mu \mathrm{m}$

13

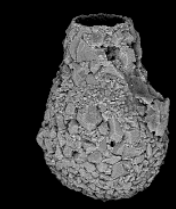

ـ $100 \mu \mathrm{m}$

17

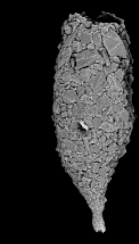

2

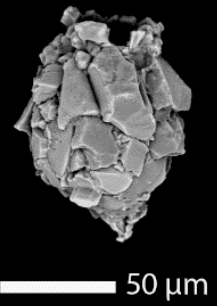

6

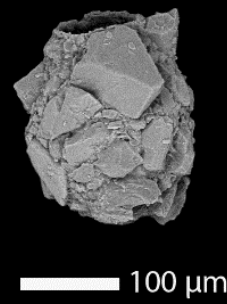

10

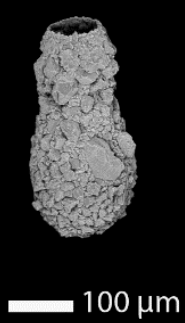

14
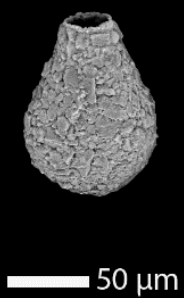

18

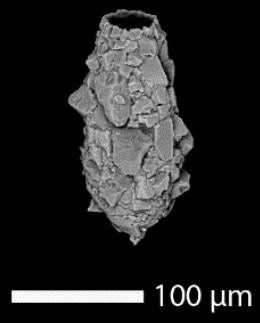

3

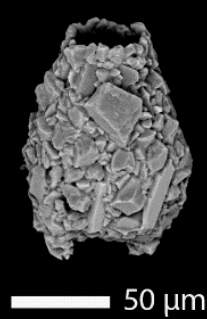

7

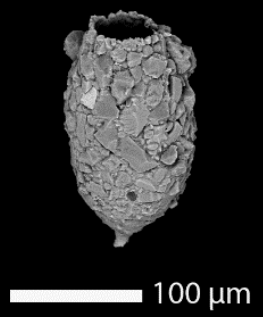

11

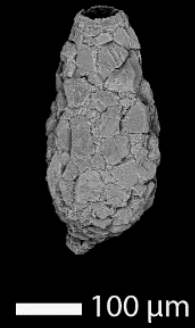

15

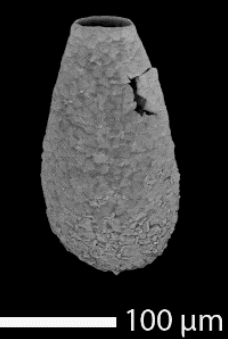

19

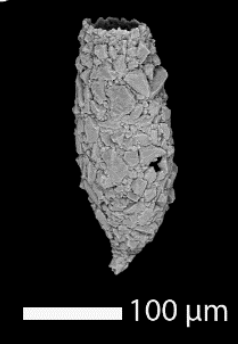

4

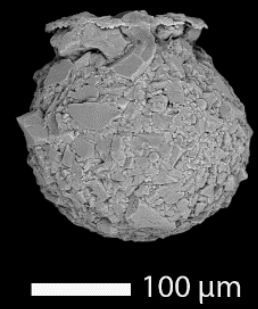

8

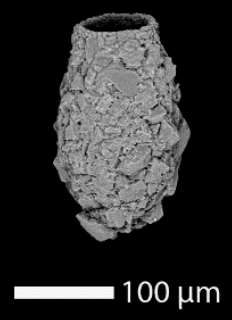

12

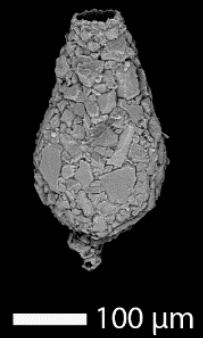

16

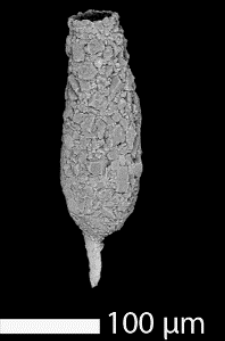

20

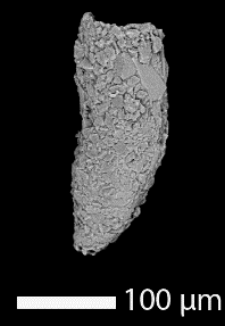


Figure 3. 3: Arcellinida from Lac du Castor Blanc and Oromocto Lake.1 Heleopera sphagni (Leidy 1874). 2 Difflugia elegans Penard 1890. 3 Difflugia bicornis Penard 1890. 4 Difflugia urceolata Carter 1864 strain "urceolata". 5 Difflugia urens Patterson, MacKinnon, Scott, and Medioli 1985. 6 Difflugia glans Penard 1902 strain "glans". 7 Difflugia glans Penard 1902 strain "distenda". 8 Difflugia glans Penard 1902 strain "magna”. 9-10 Difflugia oblonga Ehrenberg 1832 strain "oblonga". 11-12 Difflugia oblonga Ehrenberg 1832 strain "spinosa". 13-14 Difflugia oblonga Ehrenberg 1832 strain "tenuis". 15 Difflugia oblonga Ehrenberg 1832 strain "lanceolata". 17 Difflugia protaeiformis Lamarck 1816 strain "acuminata". 18 Difflugia protaeiformis Lamarck 1816 strain "claviformis". 19 Difflugia protaeiformis Lamarck 1816 strain "curvicaulis". 20 Difflugia protaeiformis Lamarck 1816 strain "sculpellum". 
where $s$ is the standard deviation of the population count and $X_{i}$ is the number of counts (i.e. Arcellinida tests) at the station being investigated. A sample was deemed statistically insignificant if the probable error exceeded the total count for a sample (Patterson and Fishbein, 1989).

Standard error $\left(\mathrm{Sxi}_{\mathrm{Xi}}\right)$ was calculated for each sample using the following equation:

$$
S_{X i}=1.96 \sqrt{\frac{F 1(1-F 1)}{N_{i}}}
$$

where $F 1$ is the fractional abundance of species and $N i$ is the total number of counts. Species were considered to be present in insignificant numbers if the standard error exceeded the total counts for that species in all the samples (Fishbein and Patterson 1993). Species with abundances higher than the standard error but are common only in a few samples were also removed as their inclusion would complicate the interpretation of ensuing statistical and multivariate analyses.

The Shannon Diversity Index (SDI; Shannon, 1948) was calculated in RStudio (version 0.98.1028) (R Core Team, 2014) to assess arcellinidan diversity as a measure of ecological health in both lakes. Samples were considered healthy if the SDI was between 2.5 and 3.5, in transition if SDI was between 1.5 and 2.5, and stressed if SDI was below 1.5 (Magurran, 1988; Patterson and Kumar, 2002). The ratio between centropyxid and difflugid species was calculated after the approach of Neville et al. (2010) and was used in tandem with SDI as a measure of the relative ecological health of the sampled lakes. 


\subsubsection{Data screening and preparation}

To avoid any issues with running the multivariate statistical analysis, data sets used in this study (Arcellinida relative abundance, lake parameters, LOI, particle size and ICP-MS) went through a screening process, which removed any variables with $>25 \%$ of data values being: 1) insignificant and, or missing data values; and, 2) above or below instrumental detection limits. Any remaining values below the detection limit were converted to half the minimum detection limit, while any value above detection limit was converted to maximum detection limit (Reinmann et al., 2008). The screening process resulted in the removal of ten measured parameters, all of which are from the ICP-MS dataset (omitted elements: boron [B], tungsten [W], Te [tellerium], Ge [germanium], Hf [Hafnium], Ta [tantalum], In [indium], Re [rhenium], Pd [palladium], and Pt [platinum])

A logarithmic transformation was performed on the dataset due to most of the parameters exhibiting a strong non-normal distribution (p-value $<0.005 ; n=$ 39/55 variables). A Hellinger transformation was used on the arcellinidan relative abundance data set as it is the recommended method of transformation when performing cluster analysis and ordination, especially linear methods like redundancy analysis, on species abundance data (Rao, 1995).

\subsubsection{Variables reduction}

A Principle Component Analysis (PCA; Pearson, 1901; Hotelling, 1933) plot was employed to evaluate redundancies in data to further reduce the number of parameters to be included in constrained ordination. 


\subsubsection{Cluster analysis}

Q-mode and R-mode cluster analysis was carried out on the 33 arcellinidan species and strains in 22 samples determined to have statistically significant counts and not missing any values in the environmental data set. Q-mode cluster analysis was used to group samples according to similarities in their faunal structure using Ward's Minimum variance method (Ward, 1963; Fishbein \& Patterson, 1993), which is recorded as squared-Euclidean distances. R-mode cluster analysis was used to determine which species and strains $(n=33)$ are most closely associated with each other and to determine the faunal composition of the identified Arcellinida assemblages. The statistical significance of the identified clusters was calculated using the PVClust package in RStudio statistical software (version 0.98.1028) (R Core Team, 2014). A two-way cluster analysis heatmap was generated using the cim function of the mixOmics package in RStudio.

\subsubsection{Detrended Correspondence Analysis (DCA)}

Detrended Correspondence Analysis (DCA; Hill, 1979) was used to determine the axil length, necessary for selecting the proper constrained ordination method (e.g. redundancy analysis vs. canonical correspondence analysis), and to compare similarities between identified Arcellinida assemblages in a multidimensional space. The results of DCA revealed that the gradient length of the species data is $<2$, which indicate that redundancy analysis is the appropriate ordination analysis for this data set. 


\subsubsection{Redundancy analysis (RDA)}

Redundancy analysis (RDA; van den Wollenberg, 1997) was used on the 22 samples and 33 statistically significant species and strains to assess and quantify the relationship between Arcellinida assemblages and the reduced measured variables. Redundancy analysis provided insight for interpreting the cluster analysis and the DCA results as it determines possible drivers of the variance in the arcellinidan distribution. Moreover, partial RDA coupled with variance partition provided an additional qualification of the proportion of the variance in the Arcellinida data set that can be attributed to the measured parameters. Variables with a $p$-value $<0.05$ were deemed to significantly contribute to the variance in the Arcellinida assemblages.

\subsubsection{Bray-Curtis Dissimilarity Matrix (BCDM)}

Bray-Curtis Dissimilarity Matrix (BCDM; Bray and Curtis 1957) was performed on both the arcellinidan relative abundance and physicochemical parameters data sets to assess the faunal homogeneity of the identified assemblages by determining the level of dissimilarity between samples representing each assemblage. Additionally, BCDM was also used to confirm whether environmental conditions and arcellinidan assemblages differed between 2010 and 2012 in Oromocto Lake (Supplementary Table 3.3). 


\subsection{Results}

\subsubsection{Lake Parameters}

Samples obtained from Gracefield Camp Cove in Lac du Castor Blanc are mostly from relatively shallow water depth (1.5-3.5 m; Supplementary Table 3.1). The lake has a median surface water $\mathrm{pH}$ and conductivity of 8.8 and $165 \mu \mathrm{m} / \mathrm{S}$, respectively (Supplementary Table 3.1). Water temperature measurements recorded in deeper water $(10.5 \mathrm{~m})$ indicate that thermal stratification develops during the summer months with a thermocline at $8.5 \mathrm{~m}$ water depth (Supplementary Table 3.4). However, the stratification must only be fully developed for a short time each year as the lake bottom waters were well oxygenated (DO levels $=12.07 \mu \mathrm{m} / \mathrm{l}$; Supplementary Table 3.4).

As in the case of Gracefield Camp Cove, Lac du Castor Blanc, the bathymetry within Wightman Cove in Oromocto Lake is relatively shallow (2-5 m), with the exception of sample O16, which was collected from a water depth of $7 \mathrm{~m}$ (Supplementary Table 3.1). The surface of the lake is characterized by notably lower $\mathrm{pH}$ (7.44) and conductivity $(21.1 \mu \mathrm{m} / \mathrm{S})$ compared to levels recorded at Lac du Castor Blanc (Supplementary Table 3.1). The prevailing W-SW wind direction and large fetch across Oromocto Lake results in the lake being unstratified with respect to dissolved oxygen ( surface $=2.4 \mu \mathrm{m} / \mathrm{l}$, bottom=2.2 $\mu \mathrm{m} / \mathrm{l}$ ) and water temperature (surface $=25^{\circ} \mathrm{C}$, bottom $=24^{\circ} \mathrm{C}$; Supplementary Table 3.4) .

\subsubsection{Textural and organic matter characteristics}

Textural and organic matter characteristics of study samples are listed in 
Supplementary Table 3.1. Samples from Lac du Castor Blanc are characterized by relatively low levels of organic matter (median $=2.7 \% ; n=6$ ), carbonates (median $=1.6 \% ; n=6)$ and minerogenic content (median $=3 \% ; n=6)$. The proportions of organic matter present at Oromocto Lake were similarly low $($ median $=2.4 \% ; n=$ 16) and were further characterized by lower carbonate (median $=0.3 \% ; n=16$ ) and higher minerogenic content (median $=19.2 \% ; n=16)$ compared to Lac du Castor Blanc. Sediments from the sampled coves in both lakes are dominated by silt $($ Lac du Castor Blanc median $=79.2 \%, n=6$; and, Oromocto Lake median $=$ $59.1 \% ; n=16$ ) with Oromocto Lake sediments having notably more sand (median sand $\%=32.9 \%, n=16 ;$ Lac du Castor Blanc median sand= 13.2\%; $n=6$ ).

\subsubsection{Identified Arcellinida Assemblages and Primary}

\section{Controls}

Thirty-four arcellinidan species and strains were identified in twenty-two samples. All samples were found to have statistically significant arcellinidan counts and none were removed from statistical analysis. Out of 34 identified species and strains, 33 occurred in statistically significant numbers with only one taxon, Heleopera sphagni (Leidy 1874), yielding statistically insignificant number of tests.

Interpretation of the two-way cluster analysis "heatmap" revealed two

distinct assemblages: 1) Lac du Castor Blanc Assemblage (LCA) (statistical significance $=99 \%[>2 \delta] ; n=6) ; 2$ ) Oromocto Lake Assemblage (OLA) (statistical significance $=94 \%[>2 \delta] ; n=16$, which was further divided into the Oromocto 
Lake 2010 Sub-Assemblage (OL10; statistical significance $=92 \%[>2 \delta] ; n=10$ ), and Oromocto Lake 2012 Sub-assemblage (OL12; statistical significance $=90 \%$ [ $>$ $2 \delta] ; n=6$ ) as shown in Figure 4. The two-way cluster analysis heatmap, however, revealed five outliers that were exclusive to OLA $\left(\mathrm{O}_{4}, \mathrm{O}_{5}, \mathrm{O}, \mathrm{O}_{7}\right.$, and $\left.\mathrm{O} 11\right)$ (Figure 4). Samples $\mathrm{O}_{4}, \mathrm{O} 6$ and $\mathrm{O} 7$ were collected during the 2010 field season but clustered separately from the remaining 2010 sample at a high level of statistical confidence (91\% [ 28 ]). The faunal composition of the three samples, however, were highly similar to that of the samples definitively comprising OL10, differing only in the proportions of minor arcellinidan taxa (relative abundance $<1.2 \%$ ). Therefore, the three samples were considered to be part of the OL10 subassemblage in this study. Sample O5 grouped with the samples collected during the 2012 samples, even though it was collected in 2010, while sample O11 that grouped most closely to the OL10 samples despite being collected in 2012 (Figure 3.4). The presence of some overlap between the sub-assemblages would be expected given the temporal and spatial nature of the study.

Results of the DCA revealed arcellinidan assemblages similar to those identified using Q- and R-mode cluster analysis (Figure 3.5). The DCA bi-plot also revealed a notable overlap between the samples of OL1O and OL12, particularly with samples $\mathrm{O}_{2}, \mathrm{O}_{3}$, and $\mathrm{O}_{5}$ plotting closely to the OL12 sub-assemblage (Figure 5). Redundancy Analysis results were consistent with both cluster analysis and DCA in that the same assemblages and sub-assemblages were observed in the RDA tri-plot (Figure 3.6A). Redundancy analysis showed that axis 1 explained most of the variance in the Arcellinida assemblages (60\%; $\mathrm{p}<0.001$ ). Along with PCA, RDA facilitated the reduction of the number of parameters to be included, by identifying 


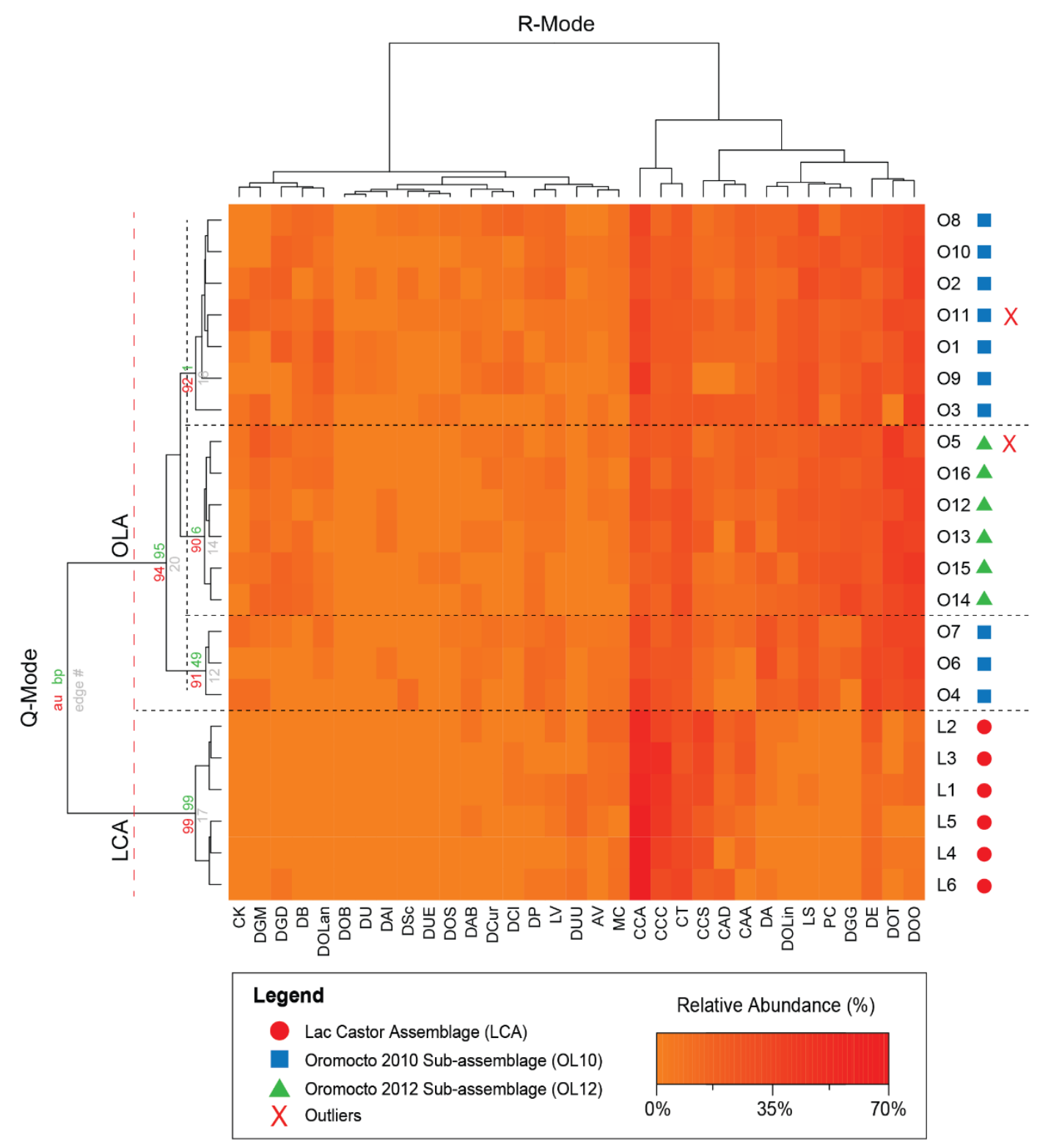


Figure 3. 4: Combined Q-mode and R-mode cluster heatmap for the 22 samples and 33 statistically significant species and strains. Two faunal assemblages, and two sub-assemblages, are indicated. The colored squares (gradient of red) reflect the relative abundances of the Arcellinida species and strains. The statistical significance of the identified assemblages, as determined by using PVClust values, is displayed next to the assemblages (red number). AV = Arcella vulgaris; $\mathrm{CAA}=$ Centropyxis aculeata "aculeata", $\mathrm{CAD}=$ Centropyxis aculeata "discoides", CCA = Centropyxis constricta "aerophila", $\mathrm{CCC}=$ Centropyxis constricta "constricta", $\mathrm{CCS}=$ Centropyxis constricta "spinosa", CT= Cucurbitella tricuspis, $\mathrm{CK}=$ Cyclopyxis kahli, $\mathrm{DB}=$ Difflugia bidens, $\mathrm{MC}=$ Mediolus corona, DGG = Difflugia glans "glans", DGM = Difflugia glans "magna", DGD = Difflugia glans “distenda", DOB = Difflugia oblonga "bryophila", DOL = Difflugia oblonga "lanceolata", DOL = Difflugia oblonga "linearis", DOO = Difflugia oblonga "oblonga", DOS = Difflugia oblonga "spinosa", DOT = Difflugia oblonga "tenuis", DP = Difflugia protaeiformis, DA = Difflugia acuminata, DCL = Difflugia claviformis; DCUR = Difflugia curvicaulis; DSC = Difflugia scalpellum; DAI = Difflugia acuminate "immanata; DAB = Difflugia acuminate "bicornis", DUU = Difflugia urceolata "urceolata", DUE = Difflugia urceolata "elongata", DU = Difflugia urens, DE = Difflugia elegans, $\mathrm{LV}=$ Lagenodifflugia vas, $\mathrm{LS}=$ Lesquereusia spiralis, $\mathrm{PC}=$ Pontigulasia compressa. 


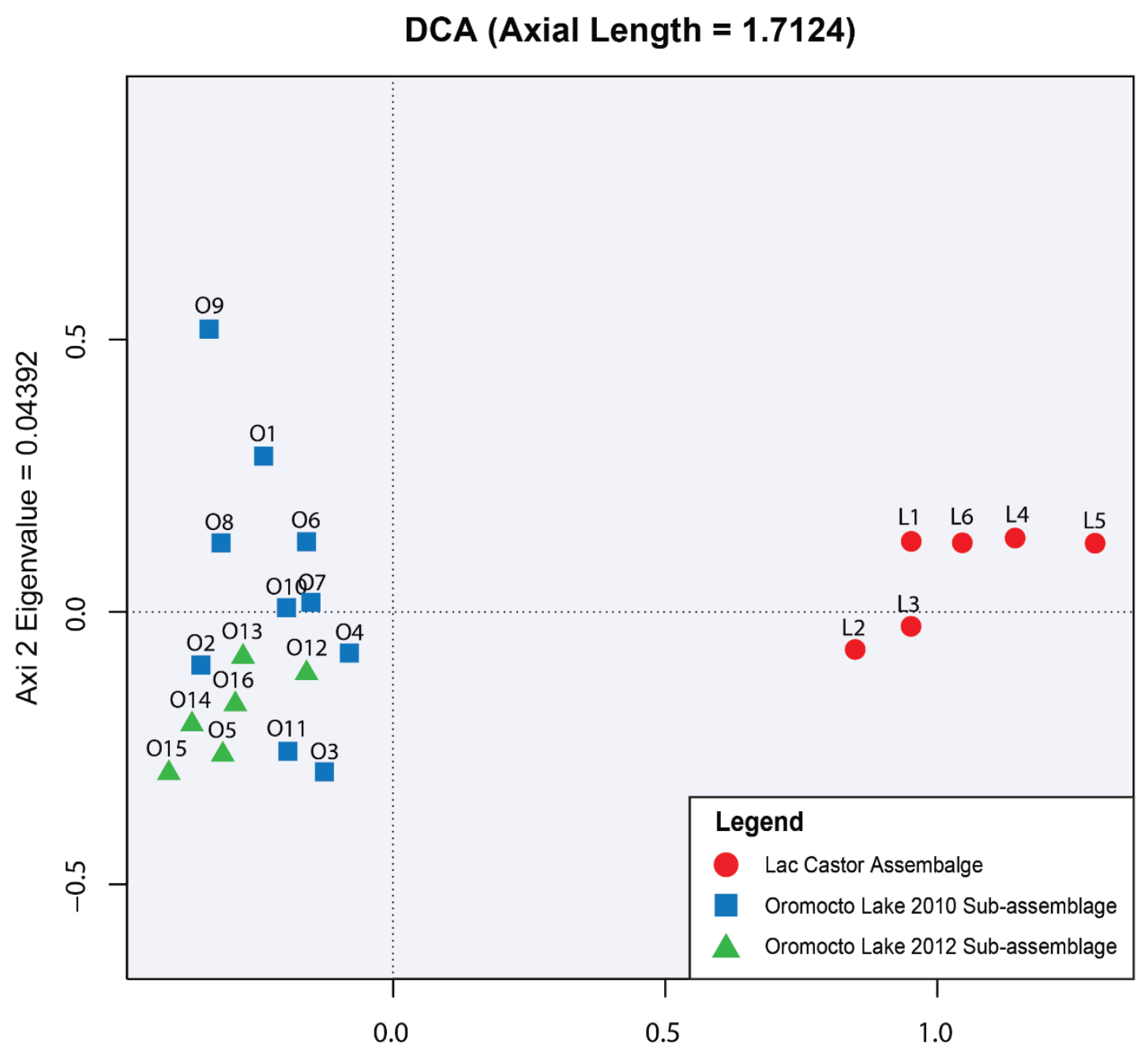

Axi 1 Eigenvalue $=0.2130$

Figure 3. 5: Detrended correspondence analysis (DCA) showing the results for the two Arcellinida assemblages and two sub-assemblages in multidimensional space. 


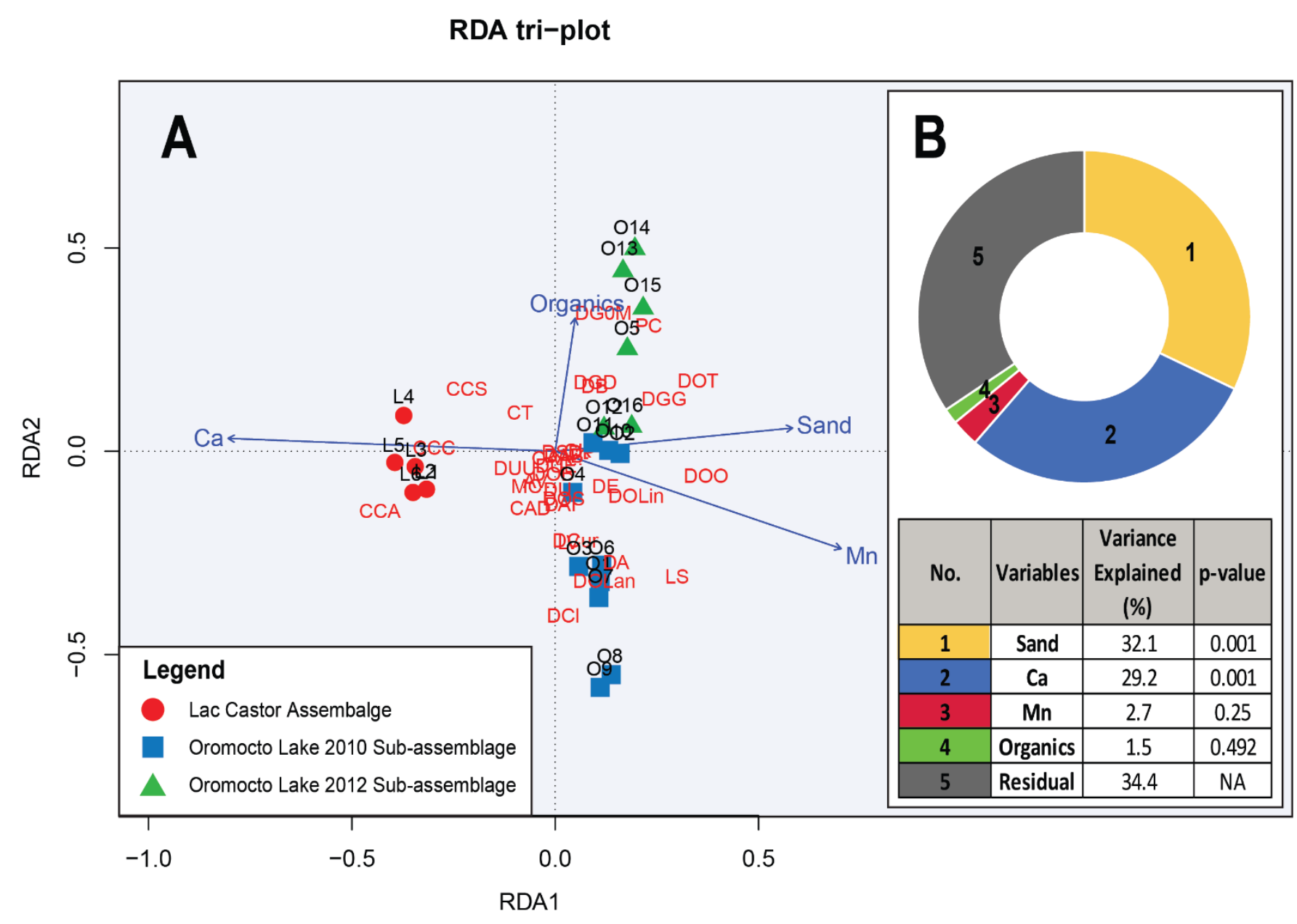


Figure 3. 6: (A) Redundancy Analysis (RDA) species-environment-sample tri-plot for the 22 surface-sediment samples that yielded statistically significant proportions of 33 Arcellinida taxa. The tri-plot also shows the assemblages and sub-assemblages and their relationship with the measured variables. (B) Partial Redundancy Analysis (pRDA) with variance partitioning test showing the percentage variance in the Arcellinida data set that is explained by the measured variables. $\mathrm{AV}=$ Arcella vulgaris; $\mathrm{CAA}=$ Centropyxis aculeata "aculeata", $\mathrm{CAD}=$ Centropyxis aculeata "discoides", CCA = Centropyxis constricta "aerophila", CCC = Centropyxis constricta "constricta", CCS = Centropyxis constricta "spinosa", CT= Cucurbitella tricuspis, CK = Cyclopyxis kahli, DB = Difflugia bidens, MC = Mediolus corona, DGG = Difflugia glans "glans", DGM = Difflugia glans “magna”, DGD = Difflugia glans "distenda" , DOB = Difflugia oblonga "bryophila”, DOL = Difflugia oblonga "lanceolata”, DOL = Difflugia oblonga "linearis", DOO = Difflugia oblonga "oblonga", DOS = Difflugia oblonga "spinosa", DOT = Difflugia oblonga "tenuis", DP = Difflugia protaeiformis, DA = Difflugia acuminata, DCL = Difflugia claviformis; DCUR = Difflugia curvicaulis $;$ DSC = Difflugia scalpellum $;$ DAI = Difflugia acuminate "immanata; DAB = Difflugia acuminate "bicornis", DUU = Difflugia urceolata "urceolata", DUE = Difflugia urceolata “elongata”, DU = Difflugia urens, DE = Difflugia elegans, LV = Lagenodifflugia vas, LS = Lesquereusia spiralis, PC = Pontigulasia compressa . 
four measured variables that collectively explain a major proportion of the variance in the identified assemblages (65.6\%; Figure 3.6B). Of the four variables, sand particle size (32.1\%) and calcium (Ca) (29.2\%) explained the majority of the total variance $(61.3 \% ; p$-value $=0.001)$. In comparison, manganese $(\mathrm{Mn})(2.7 \%)$ and organic content (1.5\%) are less significant ( $p$-value >0.001), explaining a notably lower portion of the total variance (4.3\%) (Figure 3.6B).

\subsubsection{Description of Identified Arcellinida Assemblages}

\subsubsection{Lac du Castor Blanc Assemblage 'LCA' ( $n=6)$}

The faunal structure of the Lac du Castor Blanc Assemblage (LCA) was dominated by Centropyxis constricta (Ehrenberg 1843) strain "aerophila" (median relative abundance $=44.8 \%)$, C. constricta $($ Ehrenberg 1843) strain "constricta" (median relative abundance $=19.7 \%$, and $C$. constricta $($ Ehrenberg 1843$)$ strain "spinosa" (median relative abundance $=10.2 \%$; Supplementary Table 3.5). Other centropyxids like C. aculeata (Ehrenberg 1832) strain "aculeata" (median relative abundance $=2.4 \%)$ and $C$. aculeata (Ehrenberg 1832) strain "discoides" (median relative abundance $=2.3 \%$ ) were also present but in low proportions. The dominance of centropyxid species and strains was illustrated by low $\mathrm{D} / \mathrm{C}$ ratios characterizing the samples of LCA (0.044-0.15; Supplementary Table 3.5). The assemblage was also characterized by notable number of Cucurbitella tricuspis $($ Carter 1856) $($ median relative abundance $=11.2 \%)$.

The measured SDI for samples comprising LCA (SDI range $=1.3-2$ ) was reflective of low to moderate diversity and stressed to transitional environmental 
conditions (Supplementary Table 3.5). Samples comprising the LCA were collected close to shore in relatively shallow water depth (1.5-3.5m; Figure 3.1B). These samples were retrieved from silt-dominated (median silt\% $=79.2 \%$ ) substrates characterized by relatively low organic contents ranging between $2.2-2.9 \%$ (Supplementary Table 3.5).

Q-mode cluster analysis and DCA results indicated that LCA was highly distinguishable from the Oromocto Lake assemblage (Figures 3.4, 3.5). The results of RDA tri-plot show that LCA correlates positively with $\mathrm{Ca}$, and negatively with the sand particle fraction and Mn (Figure 3.6A).

\subsubsection{Oromocto Lake Assemblage 'OLA' $(n=16)$}

Unlike the LCA, the Arcellinidan composition of the Oromocto Lake assemblage (OLA) was dominated by Difflugia oblonga Ehrenberg 1832 strain "oblonga" (median relative abundance $=15.9 \%$ ), and D. oblonga Ehrenberg 1832 strain "tenuis" (median relative abundance $=11.2 \%$; Supplementary Table 3.5 ). Of the centropxiid species and strains, only C. constricta (Ehrenberg 1843) strain "aerophila" (median relative abundance $=10.3 \%$ ) was present in high proportions. Other common species included D. elegans (median relative abundance $=7 \%$ ), Lesquereusia spiralis (median relative abundance $=6.8 \%$ ), C. tricuspis (Carter 1856) (median relative abundance $=6.5 \%$ ), D. glans Penard 1902 strain "glans" (median relative abundance $=5.5 \%$; Supplementary Table 3.5 ). The assemblage was highly diverse (SDI= 2.47-2.81) and had a high proportion of difflugids (D/C ratio=1.5-3.2; Supplementary Table 3.5). Samples of the OLA were collected from 
substrates that were silt-dominated (median silt\% $=59 \%$ ) but contained higher proportions of sand (median sand\% $=32.9 \%$ ). Compared to Lac du Castor Blanc, Oromocto Lake sediments have slightly higher levels of organic content (1.93.99\%; Supplementary Table 3.5).

The DCA bi-plot showed samples comprising the OLA clustering distinctly from the LCA samples. While the OLA samples were grouped closely, their grouping was not as tight as that of the LCA samples (Figure 3.5). The RDA tri-plot showed that samples of OLA correlated positively with the sand size fraction, Mn, and organic content, and negatively with $\mathrm{Ca}$ (Figure 3.6A).

\subsubsection{Oromocto Lake 2010 Sub-Assemblage 'OL1O’ $(n=8)$}

The faunal composition of the Oromocto Lake 2010 sub-assemblage (OL10) was dominated by Difflugia oblonga strain "oblonga" (median relative abundance = 15.6\%) and D. oblonga Ehrenberg 1832 strain "tenuis" (median relative abundance = 10\%; Supplementary Table 3.5). Other common species included C. tricuspis (median relative abundance $=6.4 \%), D$. glans strain "glans" (median relative abundance $=4.5 \%$ ), and D. oblonga Ehrenberg 1832 strain "linearis" (median relative abundance $=3.8 \%$ ). Centropyxid taxa were present but in low proportions as only $C$. constricta strain "aerophila" (median relative abundance $=13.2 \%$ ) were present in notable numbers (Supplementary Table 3.2). This assemblage was diverse (SDI $=2.47-2.81)$ and had a high proportion of difflugids $\left(\mathrm{D} / \mathrm{C}\right.$ ratio $=1.5^{-}$ 3.2). Samples of this assemblage were collected from silt-dominated substrates (median silt\% $=59 \%)$ except for sample $\mathrm{O} 2$ that was collected from silty substrates with notably high percentage of sand (median sand\% $=59.1 \%$ ). Oromocto Lake 
sediments have slightly higher levels of organic content (1.9-2.8\%) and Mn (median Mn concentration $=1522 \mathrm{ppm}$ ) relative to the Lac du Castor Blanc material. (Supplementary Figure 3.5).

While samples comprising OL10 were seen grouping closely on the DCA plot, samples $\mathrm{O}_{2}, \mathrm{O}_{3}$, and $\mathrm{O}_{5}$ appeared to overlap with the Oromocto Lake 2012 sub-assemblage (Figure 3.5). Redundancy Analysis results revealed a positive association between OL1O samples and Mn, Sand particle size, and a negative one with Ca (Figure 3.6).

\subsubsection{Oromocto Lake 2O12 Sub-Assemblage ‘OL12’ ( $n=8$ )}

Similar to what was observed in sub-assemblage OL10, the faunal composition of the Oromocto Lake 2012 sub-assemblage (OL12) was diverse with SDI measurements indicative of relatively healthy environmental conditions (SDI range $=2.53-2.81)$ and $\mathrm{D} / \mathrm{C}$ ratios reflective of the dominance of difflugiid taxa (D/C ratio $=1.4-5.1)$. The samples of this sub-assemblage were dominated $D$. oblonga Ehrenberg 1832 strain "oblonga" (median relative abundance = 17\%), and D. oblonga strain "tenuis" (median relative abundance $=17 \%$ ). Species like $C$. tricuspis (median relative abundance $=8.8 \%$ ), and D. glans strain "glans" (median relative abundance $=7.6 \%$ ) were also common members of the sub-assemblage. Members of the genus Centropyxis were present in sub-assemblage OL12 in low numbers. Samples comprising this sub-assemblage were acquired in the 2012 field season and were collected from water depths ranging from $2 \mathrm{~m}$ to $7 \mathrm{~m}$. Compared to sub-assemblage O10, samples comprising sub-assamblage OL12 were 
characterized by a small, yet notable, increase in organic content $(2.2-3.9 \%)$ and slightly lower $\mathrm{Mn}$ concentrations (median $\mathrm{Mn}$ concentration $=1177.5 \mathrm{ppm}$; (Supplementary Table 3.5).

The results of DCA were in agreement with the two-way cluster analysis heat map and showed samples of sub-assemblage OL12 loading tightly in multidimensional space (Figures 3.4, 3.5). Similar to what was observed with subassemblage OL10, the RDA plot showed that sub-assemblage OL12 correlating positively with organics and sand particle size, and negatively with the Ca (Figure 6).

\subsection{Discussion}

\subsubsection{Arcellinida assemblage homogeneity}

Cluster analysis revealed two distinct arcellinidan assemblages, with one assemblage found in Lac du Castor Blanc (LCA) and the other in Oromocto Lake (OLA). The significant difference in the faunal composition and diversity of both assemblages reflected the different limnological conditions in both lakes. The LCA reflects stressed to transitional environmental conditions in Lac du Castor Blanc, while the OLA is indicative of healthier conditions. More specifically, the low diversity LCA (SDI range $=1.3-2$ ) is dominated by opportunistic centropyxid species and strains (median D/C = 0.08) (Medioli and Scott, 1983; Patterson et al.,

1996; Reinhardt et al., 1998). Conversely, the diverse OLA (SDI range $=2.4-2.8$ ) is characterized by abundant difflugiid taxa and C. tricuspis (median $\mathrm{D} / \mathrm{C}=2.4$ ), 
which are known to thrive in organic rich substrates and healthy environmental conditions (Collins et al., 1990).

While the arcellinidan structure of both assemblages differed significantly, the faunal composition of samples characterizing each assemblage were relatively homogenous. Cluster analysis and PVClust results provide support for this assessment and with samples comprising each assemblage grouping closely with a high degree of statistical significance $(\mathrm{LCA}=99 \%[>2 \delta]$; OLA $=94 \%[>2 \delta])$ (Figure 3.4). As expected, DCA and RAD plots revealed a notable separation between the LCA and OLA, as well as a close association of centropyxiids with the LCA and difflugiids with the OLA (Figure 3.5, 3.6A). The Bray-Curtis dissimilarity matrix provided further confirmation of the distinction between both assemblages and uniformity of their faunal composition (Supplementary Table 3.3). Samples comprising each assemblage had low dissimilarity $(<0.3)$ values, in terms of the measured parameters and arcellinidan assemblage composition, and higher dissimilarity values when the LCA and OLA were compared (>0.3) (Supplementary Table 3.3). These results supported the findings of Steele et al. (2018) who confirmed the uniformity of arcellinidan assemblages in closely spaced samples collected from relatively homogenous limnological environments.

\subsubsection{Controls on Arcellinida assemblage composition}

While the RDA analysis revealed four significant measured parameters that collectively explained $65.6 \%$ of the variance recognized in the arcellinidan 
distribution, a considerable portion of the variance was explained by two variables: sand size fraction (32.1\%) and $\mathrm{Ca}(29.2 \%$; Figure 3.6B). This result is expected as values for these parameters exhibited the highest variance amongst all the measured variables in both lakes (Supplementary Table 3.1). The sedimentary composition of lacustrine substrates has been shown to influence the faunal distribution of Arcellinida, with healthy and abundant assemblages often dwell in silt- to mud-dominated substrates, while stress assemblages characterize sanddominated substrates, where populations of bacteria and other prey in these generally higher energy environments is reduced (Dalby et al., 2000; Roe and Patterson, 2006; Steele et al., 2018). A major difference in the sedimentary composition between the basins examined was that sediment samples from Oromocto Lake had higher levels of sand (median sand\% $=32.9 \% ; n=16$ ) compared to the Lac du Castor Blanc samples (median sand\% $=13.2 \% ; n=6$; Supplementary Table 3.5 ). However, the sedimentary composition of the OLA was still dominated by the silt size fraction (median silt\% $=59.1 \% ; n=16$ ), which may account for the high faunal diversity in the OLA samples.

Calcium concentrations were particularly high in Lac du Castor Blanc (median $\mathrm{Ca}=212150 \mathrm{ppm} ; n=6$ ) and comparatively lower in Oromocto Lake (media $\mathrm{Ca}=2250$ ppm; $n=16$; Supplementary Table 3.5). The RDA plot reveals a strong association between the LCA, stress-indicating arcellinidan taxa (centropyxiids) and $\mathrm{Ca}$ along the first RDA axis (Figure 3.6A). High dissolved $\mathrm{Ca}$ concentrations in water can elevate $\mathrm{pH}$ levels, which may explain why the $\mathrm{pH}$ level of Lac du Castor Blanc (median $\mathrm{pH}=8.88$ ) is significantly higher than that of Oromocto Lake (median $\mathrm{pH}=7.35$ ). The variability of $\mathrm{pH}$ in lakes has been shown 
to impact the distribution of Arcellinida (Kumar and Patterson, 2000; Patterson and Kumar, 2000; Escobar, 2008; Patterson et al., 2013). Therefore, the elevated $\mathrm{pH}$ in Lac du Castor Blanc may have contributed, along with other confounding variables, to stressing the more sensitive and specialized arcellinidan taxa (e.g. difflugiid species and C. tricuspis), thus providing a possible explanation for the relatively low $\mathrm{D} / \mathrm{C}$ ratios characterizing the LCA.

Compared to sand particle size and $\mathrm{Ca}$, the remaining contributing variables (Mn, and organic content) explain a significantly lower proportion of the total variance in the arcellinidan distribution. This reduced apparent contribution is attributed to the low variance in $\mathrm{Mn}$ concentrations and organic content across the dataset (Supplementary Table 3.1). Both variables, especially Mn, exhibited a relatively stronger influence on the distribution of Arcellinida in Oromocto Lake compared to Lac du Castor Blanc. Manganese is a redox-sensitive element that is common within the earth's crust and highly soluble in surface and ground waters (Delfino et al., 1968). The study area in Wightman Cove of Oromocto Lake is adjacent to an anticline along the western margin composed of fossiliferous Carboniferous sandstones and conglomerates. These rocks host Mn nodules (Robb, 1866), which dissolve and are carried by groundwater outflow through the many springs found along the western shore and within the lake. The Mn concentrations are higher toward the western side of the cove, suggesting that these springs are the most likely source of this assemblage control. While $\mathrm{Mn}$ is an essential micronutrient for lake biota (NAS, 1977; CWQG, 1987it can be toxic when present in high concentrations (Fales and Ohki, 1982; Davies and Brinkman, 1997). As Canadian Interim Sediment Quality Guidelines (ISQG) are yet to be 
established for $\mathrm{Mn}$, it cannot be used to assess whether levels of $\mathrm{Mn}$ in Oromocto Lake are high enough to have any adverse effects on the arcellinidan community. However, the high diversity of OLA (SDI $=2.4-2.8)$ reflects healthy environmental conditions, indicating that although $\mathrm{Mn}$ seems to influence the arcellinidan community in the lake, its impact is most likely not deleterious.

\subsubsection{Arcellinida assemblage dynamics in response to inter- annual environmental variability}

In addition to the identification of two primary arcellinidan assemblages, one each in Oromocto Lake and Lac du Castor Blanc, the recognition of two distinct subassemblages in Oromocto Lake (OL10 and OL12 sub-assemblages collected through two sampling seasons in $2010 \mathrm{CE}$ and $2012 \mathrm{CE}$ respectively) warrants special attention. The difference between sub-assemblages was driven by changes in the relative abundance of $D$. oblonga "oblonga", and D. oblonga "tenuis" which underwent a small, yet notable, increase in relative abundance in sub-assemblage OL12 (median relative abundance $=17 \%$ and $17.1 \%$, respectively; $n=6$ ) compared to sub-assemblage $\mathrm{O} 10$ (median relative abundance $=15.6 \%$ and $10 \%$, respectively; $n=10$; Supplementary Table 3.5). There was also a concurrent decline in the proportion of centropyxiid species and strains in sub-assemblage OL12. Ecosystems with higher proportions of difflugiid species and strains have previously been correlated with organic-rich substrates and relatively healthy environmental conditions (Collins et al., 1990). The increase in the proportions of difflugids here is similarly attributed to a small but significant increase in the levels 
of organic content in Wightman Cove between 2010 CE (median organic content $=2.4 \% ;$ range $=1.9-2.8 \%)$ and $2012 \mathrm{CE}$ (median organic content $=2.8 \% ;$ range $=$ 2.2-3.9\%). These results are in agreement with the findings of Steele et al (2018), who reported a similar association between the increase of both organic content of sediments from Wightman Cove, which by 2016 CE had increased significantly to a median organic content of $15.3 \%$, and the abundance of difflugiids taxa, particularly $D$. oblonga "oblonga" (median relative abundance $=22.8 \%$; range $=$ 19-26\%). The results presented here provide clear evidence of the sensitivity and responsiveness of Arcellinida assemblages to inter-annual changes in environmental conditions, and elucidates the potential of using the group as a reliable tool for monitoring subtle temporal limnological variability in lakes.

\subsection{Conclusions}

In this experiment Arcellinida species and strains from 22 surface-sediment samples from similar limnological environments in the Gracefield Camp Cove, Lac du Castor Blanc and Wightman Cove, Oromocto Lake were used to: 1) evaluate the similarity of Arcellinida assemblages found in similar limnological environments; and 2) assess inter-annual arcellinidan assemblage dynamics that developed in response to subtle temporal changes in environmental conditions that in turn developed in the same area of Wightman cove between $2010 \mathrm{CE}(\mathrm{n}=10)$ and 2012 CE $(n=6)$.

Statistical (cluster analysis and BCDM) and ordination analyses (DCA and $\mathrm{RDA})$ were used to characterize the arcellinidan assemblages identified in each 
lake, and to quantify the response of individual taxa and assemblages to variations in sedimentary geochemistry, organic content, and relative abundance of mud, silt and sand. The Q- and R-mode Cluster analysis and DCA revealed that despite broad limnological similarities, the two lakes hosted distinct arcellinidan assemblages, the LCA and OLA, characterized by a relatively homogenous faunal structure in each. RDA analysis revealed that assemblage composition was most significantly controlled by four physicochemical parameters, which explained $65.6 \%$ of the total variance: sand size fraction; $\mathrm{Ca} ; \mathrm{Mn}$; and organic content. The PVClust analysis supported by BCDM support the interpretation of distinct subassemblages OL10 and OL12 developed in the years $2010 \mathrm{CE}$ and $2012 \mathrm{CE}$ within the same region of Wightman Cove, Oromocto Lake. The OL12 sub-assemblage was characterized by higher proportions of the healthy-lake-indicating diffluggiid taxa. We hypothesize that a slight increase in lake productivity as indicated by an increase in organic content of sediments between $2010 \mathrm{CE}$ and $2012 \mathrm{CE}$ contributed to the arcellinidan assemblage change.

Results of this study demonstrate that there is a general homogeneity of assemblages found in lakes or contained sub-basins that are characterized by similar limnological conditions, which is of importance when designing sampling strategies of intra- and inter-lake research projects. The observation that subtle inter-annual changes in arcellinidan assemblage in Wightman Cove was recognizable provide confirmation that Arcellinida can be successfully deployed as a tool for monitoring limnological change at short-term time scales in lacustrine research. 


\subsection{Acknowledgements}

The authors would like to thank the New Brunswick Alliance of Lakes Association and the Oromocto Lake Association for their ongoing support. Appreciation is also extended to J.J. Wang, Nano Imaging Facility in Carleton University for assistance in obtaining SEM images. Funding for this research project was provided by NSERC Discovery (RGPIN 05329) and Carleton University Development grants (182438) awarded to RTP. We gratefully acknowledge the inkind contribution of Roy T. Patterson and Jean. L. Patterson who provided field logistical support.

\subsection{References}

Asioli A, Medioli FS, Patterson RT, 1996. Thecameobians as a tool for reconstruction of paleoenvironments in 29some Italian lakes in the foothills of the southern Alps (Orta, Varese and Canada). Journal of Foraminiferal Research 26:248-263.

Blott SJ, Pye K, 2001. GRADISTAT: A grain size distribution and statistics package for the analysis of unconsolidated sediments. Earth Surf Process Landforms 26:1237-1248.

Bray JR, Curtis JT, 1957. An ordination of the upland forest communities of southern Wisconsin. Ecology Monographs 27:325-349. 
Brown AC, 1982. Grenville iron-formations and associated stratiform zinc mineralization, Roddick Lake area, Mount Laurier Basin, Quebec. Canadian Journal of Earth Science 19(8):1670-1679.

Brown JH, Whitham TG, Morgan Ernest SK, Gehring CA, 2001. Complex species interactions and the dynamics of ecological systems: long-term experiments. Science 293:643-650.

Beyens L,Chardez D, 1995. An annotated list of testate amoebae observed in the Arctic between the longitudes $27^{\circ} \mathrm{E}$ and $168^{\circ} \mathrm{W}$. Archiv für Protistenkunde $146,219-233$.

Canadian Water Quality Guidelines, 1987. Canadian Council of Ministers of Environment, with periodic updates.

Carter HJ, 1856. Note on the freshwater Infusoria of the island of Bombay: The Annals and Magazine of Natural History 18(104):115-132.

Carter HJ, 1864. On freshwater Rhizopoda of England and India. Annals and magazine of natural history, ser 3, 13:18-39

Charman DJ, Hendon D, Woodland WA, 2000. The identification of testate amoebae (Protozoa: Rhizopoda) in peats. Quaternary Research Association, London, 147.

Collins ES, McCarthy FM, Medioli FS, Scott DB, Honig CA, 1990. Biogeographic distribution of modern thecamoebians in a transect along the eastern North American coast. In: Hemleben, C., Kaminski, M.A., Kuhnt, W., Scott, D.B. 
(Eds.), Paleoecology, Biostratigraphy, Paleoceanography and Taxonomy of Agglutinated Foraminifera. NATOAdvanced Study Institute Series, Series C, Mathematical and Physical Sciences 327:783-791.

Commission de toponymie, Quebec, 2015. Gracefield. Available at http://www.toponymie.gouv.qc.ca/ct/ToposWeb/Fiche.aspx?no_seq=114 25 (accessed 10th, October, 2018).

Core Team R, 2014. R: A Language and Environment for Statistical Computing. Available at : http://www.r-project.org (accessed 1oth, October, 2018).

Couteaux MM, 1976. Dynamisme de l'tquilibre des Th camoebienes dans quelques sols climaciques. Memoires du Museum National d'libtoire Nature le, SPrie A, Zoologie 96, l-183.

Dalby AP, Kumar A, Moore JM, Patterson RT, 2000. Utility of arcellaceans (thecamoebians) as paleolimnological indicators in tropical settings: Lake Sentani, Irian Jaya, Indonesia. Journal of Foraminiferal Research 30:135142.

Davies PH, Brinkman, SF, 1994. "Acute and chronic toxicity of manganese to exposed and unexposed rainbow and brown trout”. In Colorado Division of Wildlife. Water Pollution Studies Federal Aid Project \#F-243R-1.

Davidova R, Vasilev V, 2013. Seasonal Dynamics of the Testate Amoebae Fauna (Protozoa: Arcellinida and Euglyphida) in Durankulak Lake (Northeastern Bulgaria). Acta Zoologica Bulgaria 65:27-36. 
Delfino JJ, Bortleson GC, Lee GF.,1968. Distribution of Mn, Fe, P, Mg, K, Na, and Ca in the Surface Sediments of Lake Mendota, Wisconsin. Environmental Science and Technology 3:1189-1192.

Ehrenberg CG, 1830. Organisation, systematic und geographisches Verhältniss der Infusions-thierchen, Berlin. Druckerei der Königlichen Akademie der Wissenschaften 108.

Ehrenberg CG, 1832. Über die Entwicklung und Lebensdauer der Infusionstiere, nebst ferneren Beiträgen zu einer Vergleichung ihrer organischen systeme. Abhandlungen der Akademie der Wissenschaften Berlin 181.

Ehrenberg CG, 1840. Das grössere Infusorienwerke. Abh Akad Wiss Berlin 198219.

Ehrenberg CG, 1843. Verbreitung und Einfluss des mikroskopischen Lebens in Su"d-und Nord Amerika: Ko"nigliche Akademie der Wissenschaften zu Berlin Physikalische Abhandlungen 1841:291-446.

Environment Canada, 2015. Canadian Climate Normals: Fredericton. Available at http://climate.weather.gc.ca/climate_normals/results_1981_2010_e.htm l? stnID $=6157 \&$ lang $=e \&$ province $=\mathrm{NB} \&$ provSubmit $=$ go\&dCode $=1($ accessed 10TH, October 2018).

Environment Canada, 2015. Canadian Climate Normals: Wright. Available at http://climate.weather.gc.ca/climate_normals/results_1981_2010e.html? 
stnID $=5642 \&$ lang $=$ e\&province $=Q C \&$ provSubmit $=$ go\&page $=151 \& \mathrm{dCode}=0$ (accessed 10TH, October 2018).

Fales, SL. and K. Ohki, 1982. Manganese deficiency and toxicity in wheat: influence on growth and forage quality of herbage. Agronomy Journal 74:1070-1073.

Farooqui A, Kumar A, Swindles GT, 2012. Thecamoebian communities as proxies of seasonality in Lake Sadatal in the Ganga-Yamuna Plains of North India. Palaeontologia Electronica 15.1.3A:19.

Fishbein E, Patterson RT, 1993. Error-weighted maximum likelihood (EWML): a new statistically based method to cluster quantitative micropaleontological data. Journal of Paleontology 67:475-486.

Foissner W, 1994. High Numbers of Testate Amoebae (Protozoa) in Benthon of Clean, Acidified Mountain Streams. Limnologica 24(4):323-331.

Foissner W, Schiller W, 2001. Stable for 15 million years: scanning electron microscope investigation of Miocene euglyphid thecamoebians from Germany, with description of the new genus Scutiglypha. European Journal of Protistology 37:167-180.

Gavel MJ, Patterson RT, Nasser, NA, Galloway, JM, Roe, HM, Cott, PA, Ellis, S, 2018. What killed Frame Lake? a precautionary tale for urban planners. PeerJ 6:e4850

Gauthier M, Brown AC, 1986. Zinc and iron metallogeny in the ManiwakiGracefield district, southwestern Quebec. Economic Geology 81:89-112. 
Hanson R, 2014. Oromocto River Watershed Gaspereau Study. Parish Geomorphic Ltd. \& Oromocto River Watershed Association Inc.

Haung CG, MacDonald G, Cwynar L, 2004. Holocene landscape development and climatic change in the low arctic, northwest territories, Canada. Palaeogeography, Palaeoclimatology, Palaeoecology 205(3-4):221-34.

Heiri O, Lotter AF, Lemcke G, 2001. Loss on ignition as a method for estimating organic and carbonate content in sediments: reproducibility and comparability of results. Journal of paleoclimnology 25(1):101-110.

Hill MO, 1979. Decorana - A Fortran program for detrended correspondence analysis and reciprocal averaging. Ecology and Systematics, Cornell University, Ithaca, New York 14850:52.

Hotelling H, 1933. Analysis of a Complex of Statistical Variables Into Principal Components. Journal of Educational Psychology, volume 24, pages 417441 and $498-520$.

Kihlman SM, Kauppila, 2009. Mine water-induced gradients in sediment metals and arcellacean assemblages in a boreal freshwater bay (Petkellahti, Finland). Journal of Paleolimnology 42:533-550.

Kumar A, Patterson RT, 2000. Arcellaceans (thecamoebians): new tools for monitoring long- and short-term changes in lake bottom acidity. Environmental Geology 39:689-697. 
Lamarck JB, 1816. Histoire Naturelle des Animaux sans Vèrtèbres. Verdièie, Paris tome 2 , p. $1-568$

Laminger H, 1971. Sedimentbewohnenden Schalenamoben (Rhizopoda, Testacea) der Finstertaler Seen (Tirol). Archiv fur Hydrobiologie. 69(1):106-140.

Laminger H, Geisler-Moroder K, Siess A, Spiss E, Spiss B, 1980. Populationsdynamik terrestrischer Protozoen (Testacea, Rhizopoda) in Zentralalpinen Lagen Tirols. I. Untersuchungen subalpinen Boden in Raum Obergurgl (Tirol/Österreich). Archiv für Protistenkunde.123:280-323.

Leidy J, 1874. Notice of some new freshwater rhizopods. Journal of Natural History 14(83): 383-385.

Levin S, 1992. The problem of pattern and scale in ecology. Ecology 73:1943-1967.

Lousier JD, 1984. Population dynamics and production studies of species of Nebelidae (Testacea, Rhizopoda) in an aspen woodland soil. Acta Protozool. 23:145-159.

Magurran AE, 1988. Ecological diversity and its measurement. Princeton University Press, Prinction, 185.

Mazei YA, Tsyganov AN, 2007. Species composition, spatial distribution and seasonal dynamics of testate amoebae community in a Sphagnum bog (Middle Volga region, Russia). Protistology 5:156-206. 
Medioli FS, Scott DB, 1988. Lacustrine thecamoebians (mainly Arcellaceans) as potential tools for palaeoclimatological interpretations. Palaeogeography, Palaeoclimatology, Palaeoecology 62(1-4):361-386.

Mitchell EA, Payne RJ., Lamentowicz M, 2008. Potential implications of differential preservation of testate amoeba shells for paleoenvironmental reconstruction in peatlands. Journal of Paleolimnology 40(2):603-618.

Murray A, 2002. Is laser particle size determination possible for carbonate-rich lake sediments? Journal of Paleolimnology 27:173-183

NAS 1977, Arsenic. Medical and Biologic Effects of Environmental Pollutants. National Academy of Sciences, Washington, D.C.

Nasser NA, Patterson RT, Roe HM, Galloway JM, Falck H, Palmer MJ, Spence C, Sanei H, Macumber AL, Neville LA, 2016. Lacustrine Arcellinina (testate amoebae) as bioindicators of arsenic contamination. Microbial Ecology 72:130-149.

Neville LA, McCarthy FMG, MacKinnon MD, 2010. Seasonal environmental and chemical impact on thecamoebian community composition in an oil sands reclamation wetland in northern Alberta. Paleontologia Electronica 13(2):14. 
Patterson RT, Dalby A, Kumar A, Henderson LA, Boudreau RE, 2002. Arcellaceans (thecamoebians) as indicators of land-use change: settlement history of the Swan Lake area, Ontario as a case study. Journal of Paleolimnology 28(3):297-316.

Patterson RT, Fishbein E, 1989. Re-examination of the statistical methods used to determine the number of point counts needed for micropaleontological quantitative research. Journal Paleontology 63:245-248.

Patterson RT, MacKinnon KD, Scott DB, Medioli FS, 1985. Arcellaceans (Thecamoebians) in small lakes of New Brunswick and Nova Scotia: modern distribution and Holocene stratigraphic changes. Journal of Foraminiferal Research 15(2):114-137.

Patterson, RT, Kumar A, 2002. A review of current testate rhizopod (thecamoebian) research in Canada. Palaeogeography, Palaeoclimatology, Palaeoecology 180(1):225-251.

Patterson RT, Lamoureux ED, Neville LA, Macumber AL, 2013. Arcellacea (testate lobose amoebae) as $\mathrm{pH}$ indicators in a pyrite mine-acidified lake, Northeastern Ontario, Canada. Microbial Ecology 65(3):541-554.

Patterson RT, Roe HM, Swindles GT, 2012. Development of an Arcellacean (testate lobose amoebae) based transfer function for sedimentary phosphorous in lakes. Palaeogeography, Palaeoclimatology, Palaeoecology 348-349:3244 . 
Pearson, K, 1901. On lines and planes of closest fit to systems of points in space, Philosophical Magazine 2:559-572.

Penard E, 1890. Catalog der nackten und schalentragenden Rhizopoden von Wiesbaden. Jarbuch der nassavischen Vereins für Naturkunde 43:67-72.

Penard E, 1902. Faune Rhizopodique du Bassin du Lèman. Henry Kündig, Libraire de L’institut, Genéve pp 712.

Porter SA, Knoll AH, 2000. Testate amoeba in the Neoproterozpic Era: evidence from vase-shaped microfossils in the Chuar Group, Grand Canyon. The Journal of Paleobiology 26:360-385.

Pronk AG, Allard S, 2003. Landscape map of New Brunswick. New Brunswick. Department of Natural Resources and Energy; Minerals, Policy and Planning Division, Map NR-9. (scale 1:770 000)

Rao CR, 1995. A review of canonical coordinates and an alternative to correspondence analysis using Hellinger distance. Qüestiió 19:23-63.

Reimann C, Filzmoser P, Garrett RG, Dutter R, 2008. Statistical Data Analysis Explained: Applied Environmental Statistics with R. John Wiley \& Sons, Ltd. ISBN: 978-0-470-98581-6

Reinhardt, EG, Dalby AP, Kumar A, Patterson RT, 1998. Arcellaceans as pollution indicators in mine tailing contaminated lakes near Cobalt, Ontario, Canada. Micropaleontology 44:131-148. 
Robb C, 1968. Report of Mr. Charles Robb addressed to Sir William Logan, F.R.S., F.G.S., Director of the Geological Survey in Report of Progress From 1866 to 1869 Accompanied by Geological and Topographical Maps, p. 173-209. Dawson Bros. Montreal

Roe HM, Patterson RT, 2006. Distribution of thecamoebians (testate amoebae) in small lakes and ponds, Barbados, West Indies. The Journal of Foraminiferal Research 36(2):116-134.

Roe HM, Patterson RT, Swindles GT, 2010. Controls on the contemporary distribution of lake thecamoebians (testate amoebae) within the Greater Toronto Area and their potential as water quality indicators. Journal of Paleolimnology 43(4):955-975.

Roe HM, Patterson RT, 2014. Arcellacea (testate amoebae) as bio-indicators of road salt contamination in lakes. Microbial Ecology 68(2):299-313.

Sabina AP, 1970. Rock and Minerals for the collector, Hull-Maniwaki, Quebec; Ottawa-Peterborough, Ontario. Ottawa, Ontario: Geological Survey of Canada.

Santoro A, Held A, Linsinger TPJ, Perez A, Ricci M, 2017. Comparison of total and aqua regia extractability of heavy metals in sewage sludge: The case study of a certified reference material. Trends in Analytical Chemistry 89, 34-40. 
Schwind LT, Arrieira RL, Dias JD, Simões NR, Bonecker CC, Lansac-Tôha FA, 2015. The structure of planktonic communities of testate amoebae (Arcellinida and Euglyphida) in three environments of the Upper Paraná River basin, Brazil. Journal of limnology 75(1).

Schönborn W, 1992. Comparative Studies on the Production Biology of Protozoan communities in Freshwater and soil Ecosystems. Archiv für Protistenkunde 141:187-214.

Scott DB, Hermelin JOR, 1993. A device for precision splitting of micropaleontological samples in liquid suspension. Journal of Paleontology 67(01):151-154.

Shannon CE, 1948. A mathematical theory of communication. AT\&T Technical Journal 27(379-423):623-656.

Steele RE, Nasser NA, Patterson RT, Gregory BR, Roe HM, Reinhardt EG, 2018. An Assessment of Sub-Meter Scale Spatial Variability of Arcellinida (Testate Lobose Amoebae) Assemblages in a Temperate Lake: Implications for Limnological Studies. Microbial Ecology 76:680-694.

Thrush SF, Schneider DC, Legendre P, Whitlatch RB, Dayton PK, Hewitt JE, Hines, A H, Cummings VJ, Lawerie SM, Grant J, Pridmore RD, Turner SJ, Mc Ardle BH, 1997. Scaling- up from experiments to complex ecological systems: where to next? The Journal of Experimental Marine Biology and Ecology 216:343-254. 
van den Wollenberg AL, 1977. Redundancy analysis. An alternative for canonical correlation analysis. Psychometrika 42:207-219.

van Hengstum PJ, Reinhardt EG, Medioli FS, Gröcke DR, 2007. Exceptionally preserved late Albian (Cretaceous) Arcellaceans (Thecamoebians) from the Dakota Formation near Lincoln, Nebraska, USA. Journal of Foraminiferal Research 37:300-3008.

Wallich GC, 1864. On the process of mineral deposit in the rhizopods and sponges, as affording a distinctive character, Annals and magazine of natural history Ser $3,13: 72-82$

Ward JH, 1963. Hierarchical grouping to optimize an objective function. Journal of American Statistical Association 58: 236-244. 


\section{Chapter 4}

\section{Determining Arcellinida (testate lobose}

\section{amoeabae) Arsenic tolerance limits: A}

novel tool for biomonitoring Arsenic

\section{contamination in impacted lakes}

Nawaf A. Nasser ${ }^{1}$, R. Timothy Patterson ${ }^{1}$, Helen M. Roe ${ }^{2}$, Jennifer M. Galloway

3, Hendrik Falck 4, Hamed Sanei 5

${ }^{1}$ Department of Earth Sciences, Carleton University, Ottawa, Ontario, Canada $\mathrm{K} 1 \mathrm{~S} 5 \mathrm{~B} 6$

${ }^{2}$ School of Natural and Built Environment, Queen's University Belfast, Belfast, BT7 1NN, UK

3 Geological Survey of Canada/Commission géologique du Canada, Calgary, Alberta, Canada, T2L 2A7

4 Northwest Territories Geological Survey, Yellowknife, Northwest Territories, Canada, X1A 2L9

5 Department of Geoscience, Aarhus University, Aarhus, Denmark, 8000 


\subsection{Abstract Graphic}

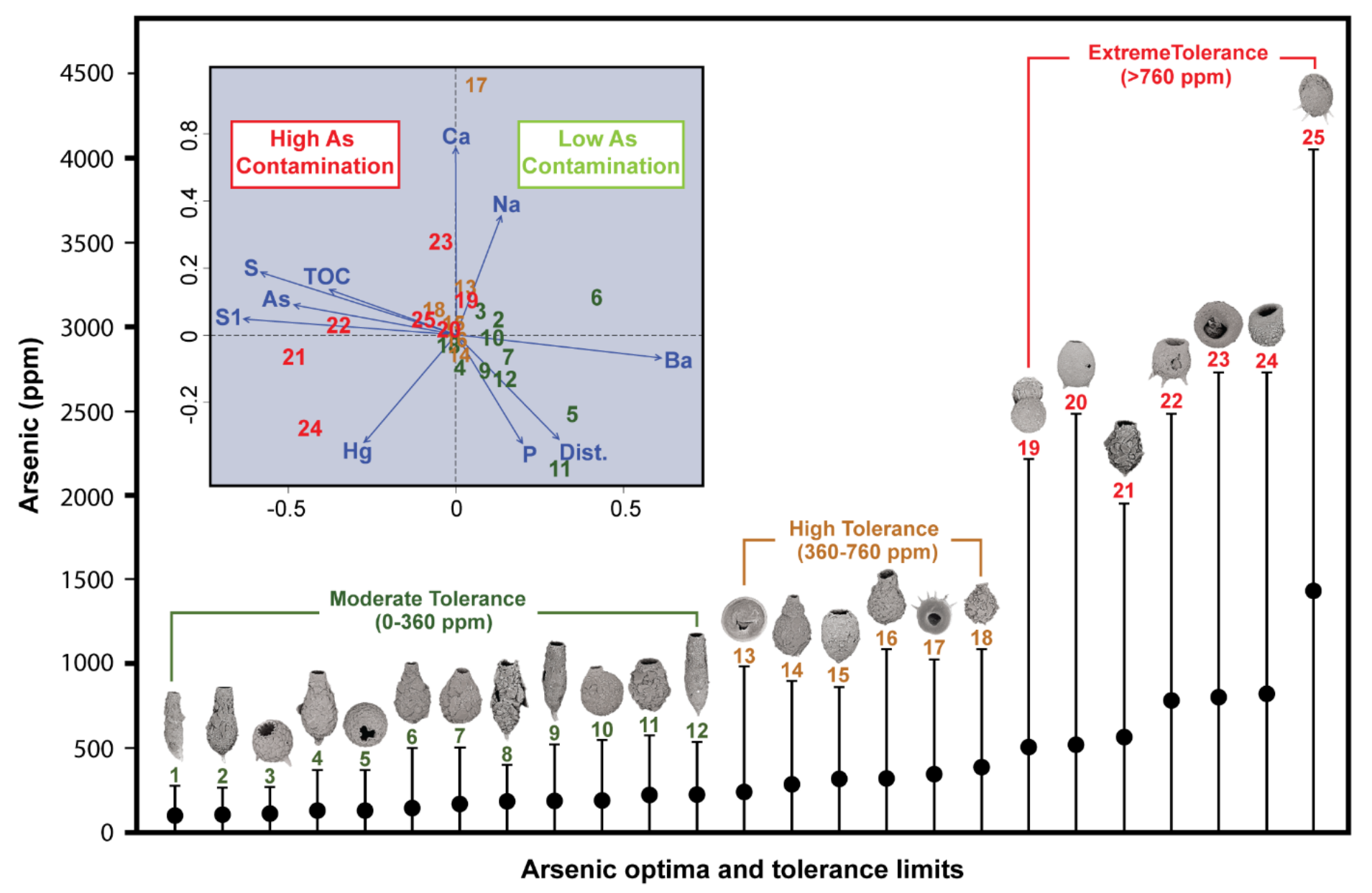




\subsection{Highlights}

- Arcellinidan response to legacy Arsenic contamination in Canadian subarctic lake sediments $(n=93)$ was investigated.

- Arsenic tolerance and optima limits were determined for 25 arcellinidan taxa.

- A shift toward healthier arcellinidan assemblages in lakes $>10 \mathrm{~km}$ from the former Giant Mine was identified.

- Three arsenic-tolerance-based faunal assemblages were used to infer As concentrations in a test dataset.

- Arcellinida can be used to monitor As contamination and change in the ecological health of impacted lakes. 


\subsection{Abstract}

Legacy As contamination from gold mining in subarctic Canada poses an emerging threat to lake biota. With climatic warming expected to increase As bioavailability in lake waters, developing tools for monitoring As variability becomes essential. Arcellinidan (testate lobose amoebae) are established lacustrine bioindicators that are sensitive to changes in environmental conditions and lacustrine ecological health. In this study, Arsenic (As)-tolerance of Arcellinida (testate lobose amoebae) in lake sediments $(n=93)$ in subarctic Northwest Territories, Canada was investigated. Arcellinida assemblage dynamics were used to delineate the geospatial extent of legacy As contamination related to the former Giant Mine (Yellowknife). The species composition of five Arcellinida assemblages correlates strongly with ten variables (variance explained $=40.4 \%$ ), with As (9.4\%) and S1carbon (labile organic matter; 8.9\%) being the most important ( $p$-value $=0.001, n$ $=84)$. Stressed assemblages characterized proximal lakes $<10 \mathrm{~km}$ from the former mine site, consistent with a recently identified, geochemically-based zone of high As-impact. We propose that As influences the spatial distribution of nutrientsensitive arcellinidans through suppression of preferred microbial food sources. Three As sensitive arcellinidan groups were identified: Moderate Tolerance Group (As=0-350 ppm); High Tolerance Group (As=350-760 ppm); and, Extreme Tolerance Group (As>750 ppm). The predictive capability of the Moderate and Extreme tolerance groups is particularly strong, correlating with As concentrations in $66.6 \%(n=20 / 30)$ of a test dataset, thus demonstrating the potential of the group for biomonitoring As contamination in impact lakes. We conclude that 
Arcellinida assemblages can be used to infer As concentrations in impacted lakes, and can provide insight into the impact of As contamination on the ecological health of lakes, a metric not captured using instrumental analyses. Lakes with Asstressed arcellinidan faunas and high As concentrations may then be targeted for further As speciation analysis to provide additional information for risk assessment.

Key words: Arsenic contamination, subarctic, Gold mining, Lake sediments, Arcellinida, Tolerance and optima analyses

\subsection{Introduction}

Arsenic (As) is a ubiquitous metal(loid), averaging $5 \mathrm{mg} / \mathrm{kg}^{-1}$ in the Earth's crust (USDHHS, 2007). Though As is valuable in various industrial applications (Wang and Mulligan, 2006), it is also a globally recognized element of environmental concern, which has been linked to several ecological and human health hazards (Caussy and Priest, 2008). Due to the mineralization of gold with As-rich sulfides gold mining mineral processing activities are a primary anthropogenic source of As in lake sediments and waters in mining districts worldwide (e.g., Borba et al., 2003; Oyarzun et al., 2004; Palmer et al., 2015; Galloway et al., 2017). Arsenic contamination of lakes is of particular concern due to the substantial recreational and ecological aquatic ecosystem services provided by these resources and its potentially high toxicity to life. Lake sediments can serve as a repository for As that can be liberated to the overlying water column under certain environmental 
conditions (e.g. seasonably variable anaerobic and redox states; Martin and Pedersen, 2002; Palmer et al., 2019).

The latent risk of gold mining-associated As contamination in lakes has been the impetus behind numerous studies focused on characterizing As in lake sediments and waters (Azcue et al., 1994; Bright et al., 1996; Andrade et al., 2010; Palmer et al., 2015; Galloway et al., 2015, 2017). Several instrumental techniques, like Instrumental Neutron Activation Analysis (e.g. Salzsauler et al., 2005), Inductively Coupled Plasma (ICP) - Atomic Emission Spectrometry (e.g., Ryu et al., 2002), and ICP - Mass Spectrometry (e.g., Galloway et al., 2017), are routinely used as means to quantify the spatio-temporal variability of total As concentrations in sediments of impacted lakes. However, results generated by such methods do not shed light on the ecological response of lacustrine ecosystems to As contamination. Additionally, several studies have highlighted limitations associated with utilizing elemental concentration profiles of redox-sensitive elements such as As, due to the potential of post-depositional remobilization (Couture et al., 2008; Andrade et al., 2010; Schuhe et al., 2017). The long-term stability of As in lake systems is dependent on its interaction with $\mathrm{Fe}, \mathrm{Mn}$, and $\mathrm{Al}$ (oxy)hydroxides, organic matter (OM), and sulfides, which in turn are mediated by factors like seasonal ice cover, $\mathrm{pH}$, redox condition, and biotic functions (e.g. microbial activity) (Toevs et al., 2006; Du Ling et al., 2009). Variability of these limnological drivers can remobilize sedimentary As, and due to associated seasonal changes in redox conditions, can result in cycling between the highly toxic inorganic species (e.g. $\mathrm{As}^{+3}$ and $\mathrm{As}^{+5}$ ) and compounds of As (e.g. arsenic trioxide $\left(\mathrm{As}_{2} \mathrm{O}_{3}\right)$, arsenite $\left(\mathrm{AsO}_{3}^{3-}\right)$, and arsenate $\left(\mathrm{AsO}_{4}^{3-}\right)$; Martin and Pedersen, 2002; 
Palmer et al., 2019). Climate change has also been shown to have a profound impact on the stability of physical, chemical and biological properties of lake systems (Rosenzweig et al., 2007). Predicted climate warming and associated changes in redox conditions may lead to the release of As from sediments into overlying surface waters in impacted lakes. There is a need to better understand the long-term spatio-temporal variability of As in lake ecosystems to better predict future geochemical trajectories and the potential impact on biota.

Benthic microfaunal communities can be sensitive to environmental change in lakes. The fossilized remains of such communities can be used to document the impact of contamination on lacustrine ecosystems through time (e.g., Dixit et al., 1989; Cattaneo et al., 2004). Arcellinida (i.e. testate lobose amoebae) are established freshwater benthic bioindicators, providing insights into both sediment character and the general ecological health of lakes (Patterson and Kumar, 2002). This cosmopolitan group of shelled protists is found within a wide geographical range that extends from the tropics to the Arctic region (Beyens and Chardz, 1995; Dalby et al., 2000) living in fresh and brackish aquatic systems (Patterson and Kumar, 2002; Charman et al., 2000). The importance of Arcellinida as bioindicators is mainly attributed to their: 1 ) reproduction (one to 11 days) that enables rapid community response to ecological change (Medioli and Scott, 1983); 2) high preservation potential owing to their decay-resistant tests (shells); and, 3) sensitivity to a wide range of environmental parameters (e.g., Kumar and Patterson, 2000; Neville et al., 2011; Patterson et al., 2013; Roe et al., 2010; Prentice et al., 2017). Such attributes offer a high degree of resolution and accuracy of environmental interpretation, which is imperative for monitoring the 
ecological health of lakes impacted by anthropogenic contamination (Neville et al., 2011; Patterson et al., 2013). Several recent studies have applied statistical techniques to evaluate the response of Arcellinida to mine-induced contamination (e.g., Kumar and Patterson, 2000; Kihlman and Kauppila, 2012), but only a few have considered the impact of As contamination on assemblage composition (Patterson et al., Reinhardt et al., 1998; Nasser et al., 2016). In 2016, As was identified as a significant control on arcellinidan distribution in lakes differentially impacted by As contamination associated with legacy gold mining operations and mineral processing at the Giant Mine site (1948-1999) in the Yellowknife area, Northwest Territories, Canada (Nasser et al., 2016; Figure 4.1). The findings of this proof-of-concept study provided new insight into the sensitivity of Arcellinida to As contamination and identified the potential of using the group as a tool for monitoring changes in As concentrations and ecological health in impacted lakes.

This study aims to further develop Arcellinida as a tool for biomonitoring variability in As concentrations and lacustrine ecological health by determining the tolerance limits of different arcellinidan taxa to varying As concentrations to identify As-indicator taxa or assemblages. A secondary objective is to assess whether quantifying arcellinidan assemblage dynamics in response to changes in As concentrations as a function of distance from Giant Mine can be used to delineate the extent of As aerial fallout zone of impact. Recent studies on the regional distribution of As in lake waters (Palmer et al., 2015) and sediments (Galloway et al., 2012, 2015) in the Yellowknife area has provided valuable information pertaining to the geospatial extent of the As contamination zone of impact. Palmer et al. (2015) delineated the limit of the zone 


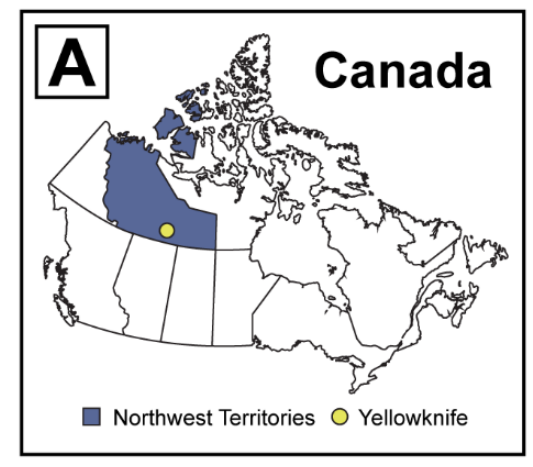

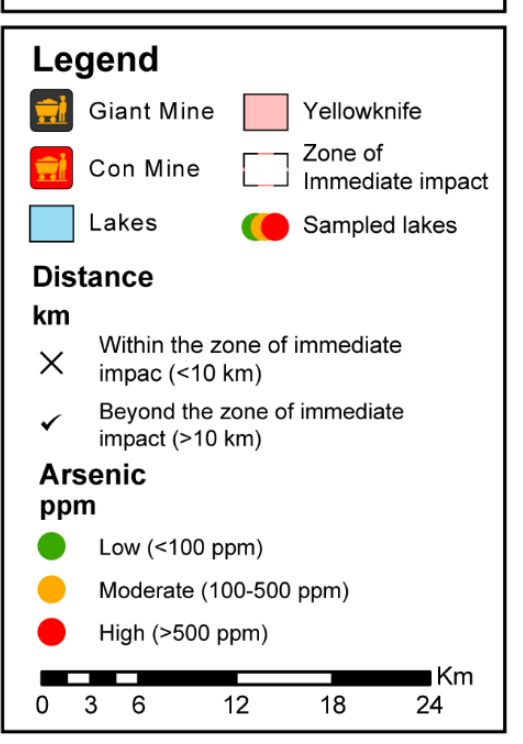

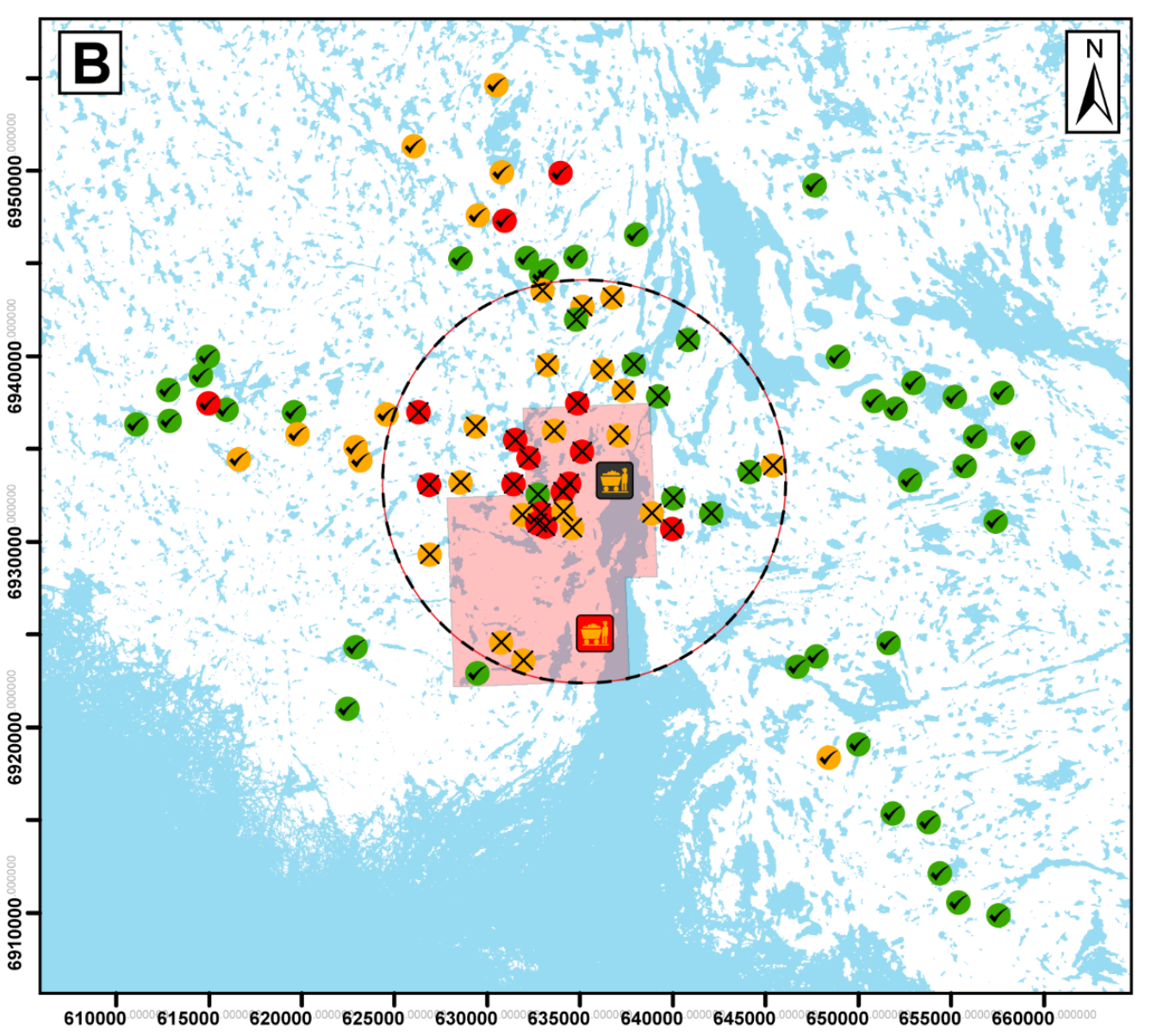

Figure 4. 1: Map of sampling sites showing the locations of the 93 near-surface sediment samples examined in the study (colored circles). The color-coding of the circles reflects the spatial distribution of As in the Yellowknife area, which is divided into three categories: high (red circles), moderate (yellow circles), and low (green circles). The dashed circle represents the outer limits of the Giant Mine zone of immediate Airborne As contamination impact. 
of significant aerial As fallout to be $\sim 17 \mathrm{~km}$ away from the historic roaster stack at Giant Mine, based on an assessment of the As concentration in 98 lake surface water samples. In an investigation of As levels in near-surface sediment samples (upper $1 \mathrm{~cm} ; n=105$ ) Galloway et al. (2017) identified a similar zone of influence as well as a zone of immediate influence with a radius of $11 \mathrm{~km}$ around Giant Mine. To achieve these objectives, the spatial distribution of Arcellinida in 93 sedimentwater interface samples from 90 lakes within a radius of $\sim 30 \mathrm{~km}$ around the Giant Mine site was examined. This study represents the largest inter-lake spatial quantification of Arcellinida response to As concentration variability and the first attempt to determine the tolerance limit of Arcellinida taxa to variations in As concentration in lake systems. The dataset used in this study is a subset of the data used by Galloway et al. (2017; $n=105)$ and is thus directly comparable to that research.

\subsection{Study Area}

The study was carried out in lakes within a radius of $\sim 30 \mathrm{~km}$ around the Giant Mine, a former gold mine located $\sim 5 \mathrm{~km}$ northeast of the city of Yellowknife (Figure 1). Detailed information pertaining to the history of gold mining in the Yellowknife area is provided in Appendix C (7.3.1). The study area is characterized by a gradual change in elevation, from $157 \mathrm{~m}$ above mean sea level (MASL) close to Great Slave Lake to 350-400 m above MSAL to the north of Thistlethwaite Lake (Kerr and Wilson, 2000). The primary drainage in the river catchment is via the Yellowknife River, which flows southward into Yellowknife Bay, Great Slave Lake. Yellowknife 
has a subarctic, continental climate characterized by short, dry, cool summers with a mean annual temperature of $-4 \cdot 3^{\circ} \mathrm{C}$ and a low mean annual precipitation of 170.7 mm (Environmental Canada, 2019). The wind direction is variable throughout the year, but blows primarily from the east and south (Pinard et al., 2007).

Lakes investigated in this study are underlain by rocks assigned to the Yellowknife Supergroup of the southern Slave structural province of the Canadian Shield. These include Archean metavolcanic and metasedimentary rocks intruded by younger granitoids and diabase dykes (Yamashita et al., 1999; Cousens et al., 2000). The most prevalent surficial sediments in the study region are fine clastic lacustrine sediments from Glacial Lake McConnell and glacigenic sediments that form a thick (<2 m) discontinuous veneer (Kerr and Wilson, 2000). Accumulations of Holocene-aged peat also occur in the study region and can be greater than $1 \mathrm{~m}$ thick in bogs and wetlands (Kerr and Wilson, 2000).

\subsection{Materials and Methods}

\subsubsection{Field methods}

A total of 93 surface sediment samples were collected from 90 lakes around the sites of Giant and Con Mines in 2012 (sample ID: B12; $n=61$ ) and 2014 (sample ID: Y14; $n=32$; Figure 4.1). Lakes located within a radius of $30 \mathrm{~km}$ from the mines were targeted to ensure coverage of areas beyond the Airborne As fallout zones of impact $(\sim 17 \mathrm{~km})$ and immediate impact $(\sim 11 \mathrm{~km})$ proposed by Palmer et al. (2015) 
and Galloway et al. (2017). Lakes were accessed via a pontoon-equipped Bell Long Ranger helicopter. Surface sediment samples were collected using an Ekman Grab and the upper $1 \mathrm{~cm}$ of sediment from each grab, where Arcellinida populations are often abundant, was retained using an inert plastic laboratory spoon for arcellinidan, sedimentological and geochemical analyses. The location of each sampling station was recorded by Global Positioning System (GPS) (Galloway et al., 2015, 2017). The water sampling depth at each station was determined using a HONDEX Honda portable handheld depth sounder (model: PS-7; Galloway et al., 2015, 2017). Where possible, muddy substrates from the middle of each lake were selected for sampling as arcellinidan populations are typically reduced on nutrientpoor silt to sand substrates (Patterson and Kumar, 2002). Water property data (pH, water temperature, dissolved oxygen and conductivity) were collected from

each sample site using a YSI Professional Plus handheld multi-parameter unit with quatro-cable (Galloway et al., 2015, 2017).

\subsubsection{Laboratory methods}

Samples used in this study were subsampled and analyzed for element and organic geochemical, sedimentological, and micropaleontological analysis. Elemental concentrations of the sediment subsamples were analyzed using ICP-MS following aqua regia digestion (ICP-MS $1 \mathrm{~F} / \mathrm{AQ} 250$ package) at Bureau Veritas, Vancouver (Supplementary Table 4.1). Aqua regia digestion was used instead of complete digestion as the former provides the total concentration of metal(loids) that could potentially become bioavailable, while the latter can volatilize As (Parsons et al., 
2012). Analytical precision was assessed using three Pulp duplicates. Calculated Relative Percent Difference (RPD) is less than $5 \%$ for As (RPD range $=1.47 \%$ 4.31\%). Analytical accuracy was assessed using three standard reference materials: 1) STD DS9 $(n=9)$; 2) STD D10 $(n=2)$; and, 3) STD OREAS45EA $(n=11)$. Mean As concentrations measured in STD DS9 is $27.4 \mathrm{ppm} \pm 1.42(n=9)$ compared to an expected aqua regia concentration of $25.5 \mathrm{ppm}$ (mean RPD $=7.806 \% \pm 3.95)$. Mean As concentrations measured in STD DS10 is $45.6 \mathrm{ppm} \pm 0.1 \quad(n=2)$ compared to an expected aqua regia concentration of $46.2 \mathrm{ppm}($ mean $\mathrm{RPD}=$ $1.307 \% \pm 0.3101)$. Mean measured As concentration for STD OREAS45EA is $9.7 \mathrm{ppm} \pm 1.16(n=11)$ compared to an expected aqua regia As concentration of 10.3 ppm (mean RPD $=11.1 \% \pm .7 .27$ ). Analyzing eleven laboratory methods blanks resulted in detecting As in only two blanks (detected As concentrations = $0.2 \mathrm{ppm}$ and $0.1 \mathrm{ppm})$.

Particle size analysis (PSA) was performed on the sediment subsamples to recognize sedimentological patterns across the study area that may influence the distribution of Arcellinida and element concentrations. Subsamples were prepared for PSA by digesting subsamples in a heated bath $\left(70 \mathrm{C}^{\circ}\right)$ with $10 \% \mathrm{HCl}$ and $30 \%$ $\mathrm{H}_{2} \mathrm{O}_{2}$ to remove carbonate and organic content, respectively (Murray 2002; van Hengstum et al., 2007). Following digestion, sedimentary grain size in each subsample was analyzed using a Beckman Coulter LS13 320 laser diffraction analyzer fitted with a universal liquid medium (ULM) sample chamber over a measurement range between 0.4 and 200olm. Samples were loaded into the instrument until an obscuration level of $10 \pm 3 \%$ was attained. GRADISTAT (Version 8; Blott and Pye, 2001) was used to compile the results (Supplementary 
Table 4.1). Garnet15 (mean diameter $15 \mu \mathrm{m}: \pm 2 \mu \mathrm{m}$ ), an accuracy standard supplied by Beckman Coulter, was run once per month. An in-house mud sample (Cushendun Mud; mean diameter $=20.5 \mu \mathrm{m}: \pm 0.76 \mu \mathrm{m}$ ) was run at the start of every session as a precision control.

Sediment subsamples were also analyzed for organic matter content using the Rock-Eval@ 6 instrument at the Geological Survey of Canada, Calgary. RockEval $\mathbb{R} 6$ Analysis uses heat to break down large organic matter molecules to smaller and chemically more identifiable molecules (Lafargue et al., 1998). Quantitative measurements of total organic carbon (TOC) and other organic geochemical variables, including S1 carbon, S2 carbon, and S3 carbon were produced (Supplementary Table 4.1). S1-carbon represents the quantity of free hydrocarbons in sediments (mg hydrocarbons/g) that are devolatilized during pyrolysis at $300{ }^{\circ} \mathrm{C}$. In sediment-water interface sample, S1 mainly consists of readily degradable geolipids and pigments predominantly derived from autochthonous organic matter such as algal-derived lipids (Carrie et al., 2012). S2carbon represents the quantity of large molecules, kerogen-derived hydrocarbons released through thermal cracking of the organic matter, in sediment samples (mg hydrocarbons/g) near $650{ }^{\circ} \mathrm{C}$. The S2 compounds in sediment generally correspond to highly aliphatic biomacromolecule structures of algal cell walls (Meyers and Teranes, 2001. S3 represents the amount of carbon dioxide released during pyrolysis of kerogen, while in sediment samples it represents lignins, terrigenous plant materials, humic and fulvic acids (Carrie et al., 2012). The quantity of all organic matter released during pyrolysis and oxidation heating accounts for TOC (wt.\%) in sediment samples. Analyses of standard reference 
material (IFP 1600oo, Institut Français du Pétrole and internal 9107 shale standard, Geological Survey of Canada, Calgary; Ardakani et al., 2016) show accuracy and precision to be greater than $5 \%$ relative standard deviation.

Sediment subsamples $\left(3 \mathrm{~cm}^{3}\right)$ were used for micropaleontological analysis. Subsamples were first wet sieved through a $297 \mu \mathrm{m}$ and a $37 \mu \mathrm{m}$ meshes to remove any coarse debris (e.g. grass and sticks) and separate Arcellinida from the clay fraction, respectively. A wet splitter (Scott and Hermlin, 1993) was used to subdivide each subsample into six aliquots for quantitative analysis. Aliquots were identified and enumerated wet for the contained Arcellinida tests on a gridded petri dish using an Olympus SZH dissecting binocular microscope (7.5-64X magnification) until, whenever possible, a statistically significant number of specimens were quantified (Supplementary Table 4.1; Patterson and Fishbein, 1989). Identification of Arcellinida primarily followed the illustrations and descriptions found in various key papers where specimens are well illustrated (e.g. Reinhardt et al., 1998; Roe et al., 2010; Patterson et al., 2013). Scanning electron microscope images of common species and strains were obtained using a Tescan Vega-II XMU VP scanning electron microscope (SEM) in the Carleton University Nano Imaging Facility. All SEM plates were digitally produced using Adobe Photoshop $^{\mathrm{TM}}$ CC 2018 (Figure 4.2; Figure 4.3).

\subsubsection{Data screening, variables reduction}

The data were screened to remove samples or variables characterized by $>25 \%$ missing values and values below or above the method detection limit (MDL; 
Reimann et al., 2008). Samples with geochemical results below MDL were converted to $1 / 2$ MDL. For values above the upper MDL upper detection limit is used (applicable only to sample BC19; Reimann et al., 2008). These criteria resulted in the removal of five samples from the analyses (B44, B56, B59, Y56, Y59).

Because the inclusion of all measured variables in ordination analyses (e.g. redundancy analysis) creates clutter that can mask meaningful patterns generated by these methods, we used the Spearman's Rank correlation and Variance Inflation Factor (VIF) to reduce the number of variables used in the analyses. Spearman's Rank correlation served to remove highly correlated variables $\left(\mathrm{r}_{\mathrm{s}}>0.7\right)$ (Supplementary Table 4.2), while VIF was employed to ensure the removal of highly collinear variables (VIF $>10$ ) (Supplementary Table 4.3). Although TOC had collinear features with a number of variables (e.g. As and S1-carbon) it was retained for statistical analyses as this variable is known to influence the distribution of several key arcellinidan taxa as well as sediment chemistry (Patterson and Kumar, 2002).

\subsubsection{Statistical analyses}

Thirty arcellinidan species and strains were identified in this study. Statistical analysis carried out on the Arcellinida dataset is described in Nasser et al (2016). Based on calculated Probable Error (pe) and Standard error (Sxi), six samples (B10, B20, B48, B55, B59, and Y69) characterized by statistically insignificant populations and five statistically insignificant species (four species and one strain) 
were excluded from subsequent multivariate data analyses (Supplementary Table 4.1).

RStudio statistical software (version 0.98.1028; R Core Team, 2014) was used to carry out several statistical and multivariate analyses on measured parameters and species data. Q-and R- mode cluster analysis, using Ward's Minimum variance method and Euclidean distance (Ward, 1963) was used to group samples containing similar Arcellinida and to determine which species were most closely associated with each other. Non-metric multidimensional scaling (NMDS; Kruskal, 1964) was used to further investigate the results of cluster analysis by assessing the similarity between identified assemblages in multidimensional space. Redundancy analysis (RDA; van den Wollenberg, 1977) of the post-screening data sets (84 samples and 25 species and strains) was used to evaluate the relationship between arcellinidan assemblages and measured environmental variables. A series of partial RDAs (pRDA), coupled with variance partitioning tests, were carried out to identify the significance of the RDA axes (Supplementary Table 4.4) and measured variables (Supplementary Table 4.5). Variables with a $p<0.05$ were considered to be significant contributors to variance in the arcellinidan assemblage. Analysis of Arcellinida tolerance and optima to As spatial variability was carried out using Weighted Average Tolerance and Optima (WATO; Ter Braak and Barendregt, 1986) methods performed through the package 'analogue' in RStudio. The method produced ecological optima values and tolerance limits (upper and lower limits) for each identified taxon, which is necessary for the identification of indicator-species and/or assemblages (Supplementary Table 4.6a). 


\subsection{Results and Discussion}

\subsubsection{Spatial Distribution of As}

Sedimentary As concentrations are higher than the levels proposed by the interim sediment quality guidelines (ISQG; $5.9 \mathrm{ppm}$; CCME, 2002) and probable effect level guidelines (PEL; $17 \mathrm{ppm}$; CCME, 2002) in 94\% ( $n=84)$ of the samples ( $n=89$; Supplementary Table 4.1). This is particularly evident in lakes to the west (median As $=290.4 \mathrm{ppm} ;$ range $=30.2-4778.2 \mathrm{ppm} n=27)$ and north $($ median As $=147 \mathrm{ppm}$; range $=16.1-10000$ ppm $n=24)$ of Giant Mine. Median As levels in lakes to the east (As $=36.3 \mathrm{ppm} ;$ range $=9.7-553.9 \mathrm{ppm} n=19)$ and south $($ median As $=31.3$ ppm; range $=6.3-317.8 \mathrm{ppm} n=13)$ of the mine site are comparatively lower, yet remain above the ISQG and PEL guidelines.

A negative Spearman's Rank coefficient between sedimentary As concentration and the distance from the roaster site $\left(r_{s}=-0.5\right)$ indicates decreasing As concentrations in distal lakes (Supplementary Table 4.2). This spatial pattern reflects the influence of the prevailing southeasterly winds (Pinard et al., 2007), which transported As-bearing stack emissions from the Giant and Con mines toward the northwest (Palmer et al., 2015; Galloway et al., 2017). The influence of prevailing wind direction may also explain the persistence of elevated levels of As in distal lakes to the north $(\mathrm{B} 2$; distance $=17 \mathrm{~km}, \mathrm{As}=905.2 \mathrm{ppm})$ and west of the historic mining operations $(\mathrm{Y} 15$; distance $=21.5 \mathrm{~km}$; As 
1

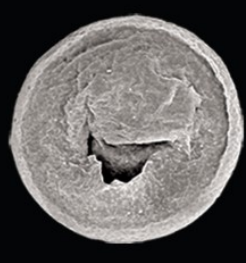

Arcella vulgaris

5

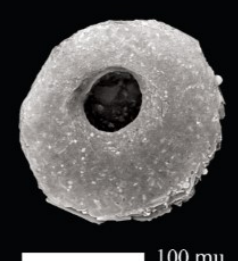

Centropyxis aculeato "discoides"

9

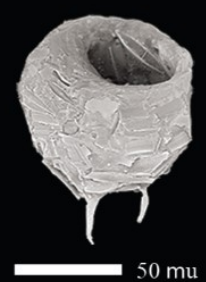

Centropyxis constricta "constricta"

13

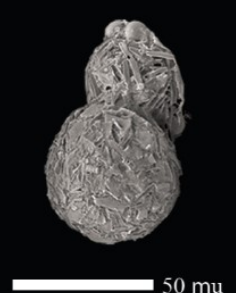

Conicocassis pontigulasiformis

18

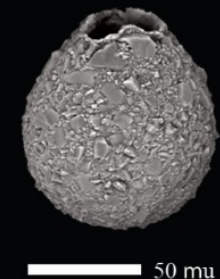

Cucurbitella tricuspis
2

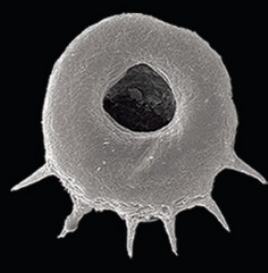

$200 \mathrm{mu}$

Centropyxis aculeato "aculeata"

6

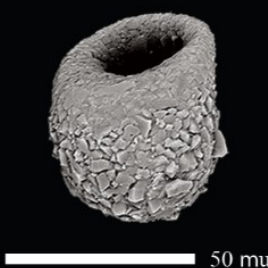

Centropyxis constricta

"aerophila"

10

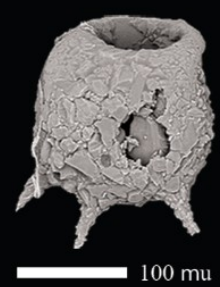

Centropyxis constricta "constricta"

14

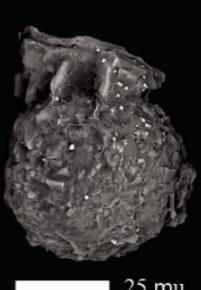

Conicocassis pontigulasiformis

19

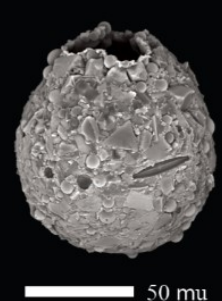

Cucurbitella tricuspis
3

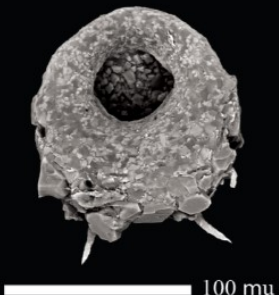

Centropyxis aculeata "aculeata"

7

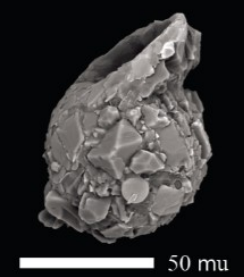

Centropyxis constricta "aerophila"

11

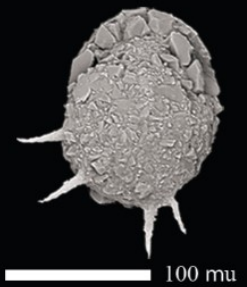

Centropyxis constricta "spinosa"

16

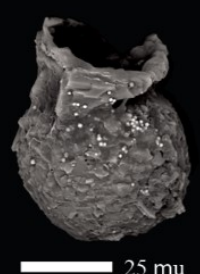

Conicocassis pontigulasiformis

20

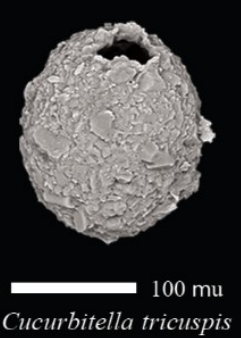

4

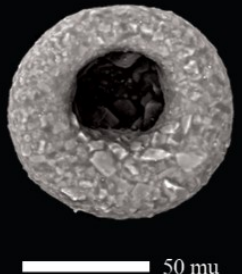

Centropyxis aculeata "discoides"

8

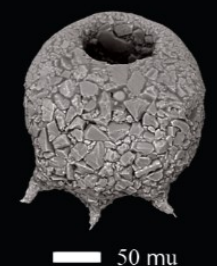

Centropyxis constricta

"constricta"

12

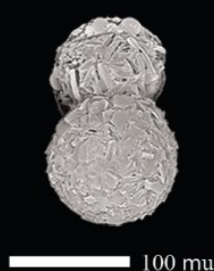

Conicocassis pontigulasiformis

17
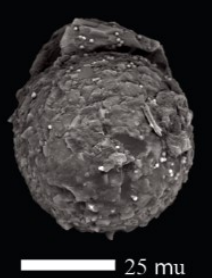

Conicocassis pontigulasiformis

21

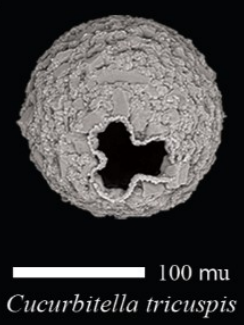


Figure 4. 2: Scanning electron microscope of selected arcellininid tests from the study lakes. For more specimen information see SA 7. 1 Arcella vulgaris Ehrenberg 1830. 2-3 Centropyxis aculeata (Ehrenberg 1832) stain "aculeata". 4-5 Centropyxis aculeata (Ehrenberg 1832) stain "discoides". 6-7 Centropyxis constricta (Ehrenberg 1843) stain "aerophila". 8-10 Centropyxis constricta (Ehrenberg 1843) stain "constricta”. 11 Centropyxis constricta (Ehrenberg 1843) stain "spinosa". 12-17 Conicocassis pontigulasiformis (Beyens, Chardez and De Bock 1986) Nasser and Patterson 2015. 18-21 Cucurbitella tricuspis (Carter 1856). 
1

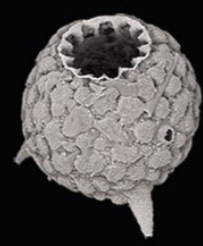

$100 \mathrm{mu}$

Mediolus corona

5

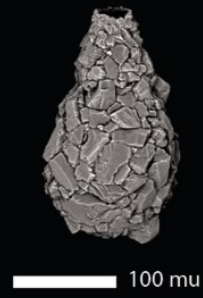

Lagenodifflugia vas

9

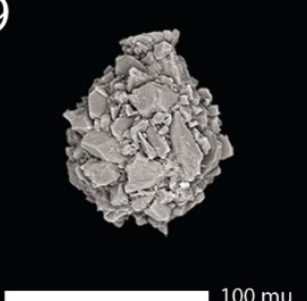

Difflugia urens

13

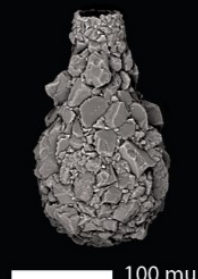

Difflugia oblonga

"oblonga"

17

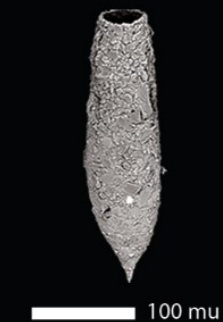

Difflugia protaeiformis "acuminata"
2

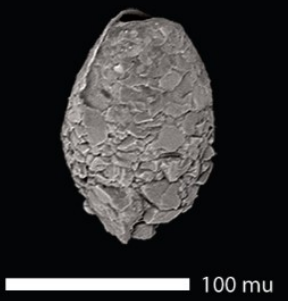

Heleopera sphagni

6

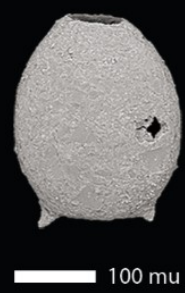

Difflugia bidens

10

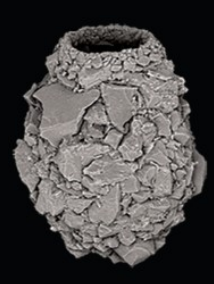

$100 \mathrm{mu}$

Difflugia glans

"glans"

14

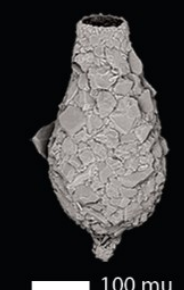

Difflugia oblonga

"spinosa"

18

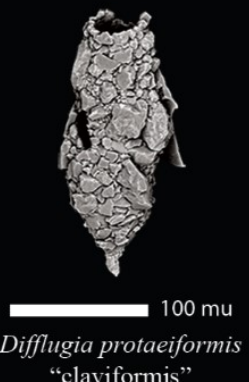

3

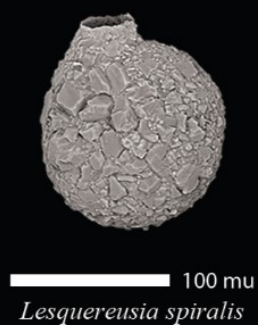

7

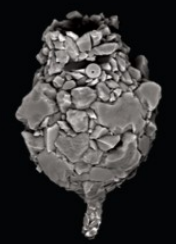

$50 \mathrm{mu}$

Difflugia elegans

11
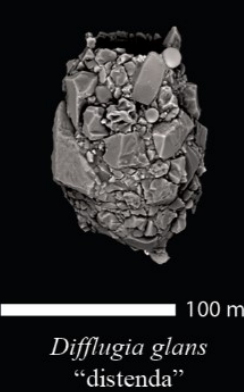

15

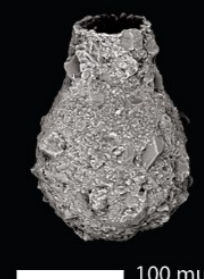

Difflugia oblonga "tenuis"

19

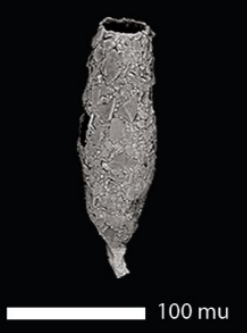

Difflugia curvicaulis
4

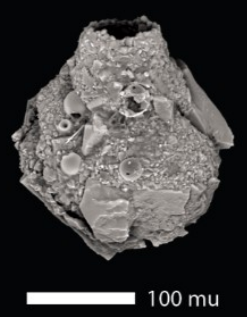

Pontigulasia compressa

8

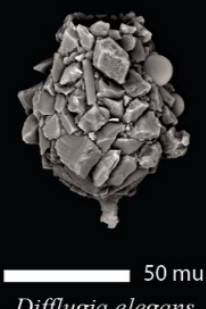

Difflugia elegans

12

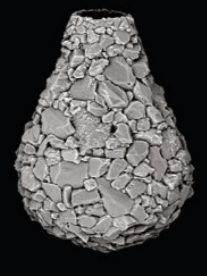

$100 \mathrm{mu}$

Difflugia oblonga

"oblonga"

16

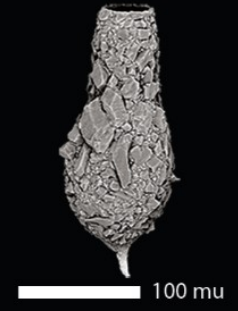

Difflugia protaeiformis

"protaeiformis"

20

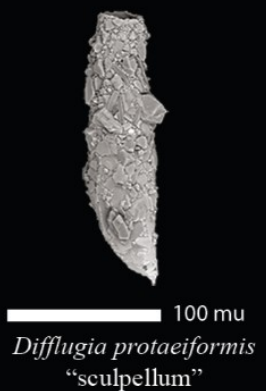


Figure 4. 3: Scanning electron microscope of selected Arcellinidan tests from the study lakes. 1 Mediolus corona (Wallich 1864) specimen from sample BC 51. 2 Heleopera sphagni (Leidy 1874) specimen from sample BC 9. 3 Lesquereusia spiralis (Ehrenberg 1840) specimen from sample BC52. 4 Pontigulasia compressa (Carter 1864) specimen from sample BC 30. 5 Lagenodifflugia vas (Leidy 1874) specimen from sample BC 9. 6 Difflugia bidens Penard 1902 from sample BC 6. 78 Difflugia elegans Penard 1890. 9 Difflugia urens Patterson, MacKinnon, Scott, and Medioli 1985 specimen from sample BC 27. 10 Difflugia glans Penard 1902 strain "glans" specimen from sample BC 52. 11 Difflugia glans Penard 1902 strain “distenda”. 12-13 Difflugia oblonga Ehrenberg 1832 strain "oblonga”. 14 Difflugia oblonga Ehrenberg 1832. 15 Difflugia oblonga Ehrenberg 1832 strain "tenuis". 16 Difflugia protaeiformis Lamarck 1816 strain "protaeiformis". 17 Difflugia protaeiformis Lamarck 1816 strain "acuminata". 18 Difflugia protaeiformis Lamarck 1816 strain "claviformis". 19 Difflugia curvicaulis Penard 1899. 20 Difflugia scalpellum Penard 1899. 
= 689.9). Although geogenic As is elevated in the Yellowknife area (background concentration $=150 \mathrm{ppm}$; Risklogic, 2002), its contribution of As to these lakes is expected to be minimal with recent studies confirming the persistence of $\mathrm{As}_{2} \mathrm{O}_{3}$ in lake sediments downwind of Giant Mine (Galloway et al., 2017; Schuh et al., 2017; Van den Berghe et al., 2017).

\subsubsection{Arcellinida Assemblages}

The results of Q-mode cluster analysis (Figure 4.4), and NMDS (Figure 4.5) reveal five distinct arcellinidan assemblages: 1) "High As Contamination Assemblage (HAC)"; 2) "As contamination Assemblage (AC)"; 2) "Centropyxis aculeata Assemblage (CA)"; 3) “Transitional Assemblage (T)”; and 4) “Healthy Assemblage (H)”. Results of the R-mode cluster analysis suggests that only seven out of the 25 identified arcellinidan taxa (Difflugia elegans Penard, 1890, Centropyxis constricta (Ehrenberg, 1843) "constricta", Centropyxis constricta (Ehrenberg, 1843) "aerophila", Centropyxis aculeata (Ehrenberg, 1843) "aculeata", Cucurbitella tricuspis (Carter, 1856), Difflugia oblonga Ehrenberg, 1832 "oblonga" and Difflugia glans Penard, 1890 "glans") contribute significantly to defining the derived faunal assemblages (Figures 4.4, 4.5; Supplementary Table 4.1). The dominance of these taxa coupled with the unique faunal structure of each assemblage reflects ecological conditions characteristic of stressed (e.g. HAC, AC, and CA; SDI values 1.3-2.2), transitional (e.g. T; SDI values 1.6-2.5) and relatively healthy lacustrine systems (e.g. H; SDI values 1.7-2.4). The variability in environmental conditions reflected by the assemblages developed mostly in 


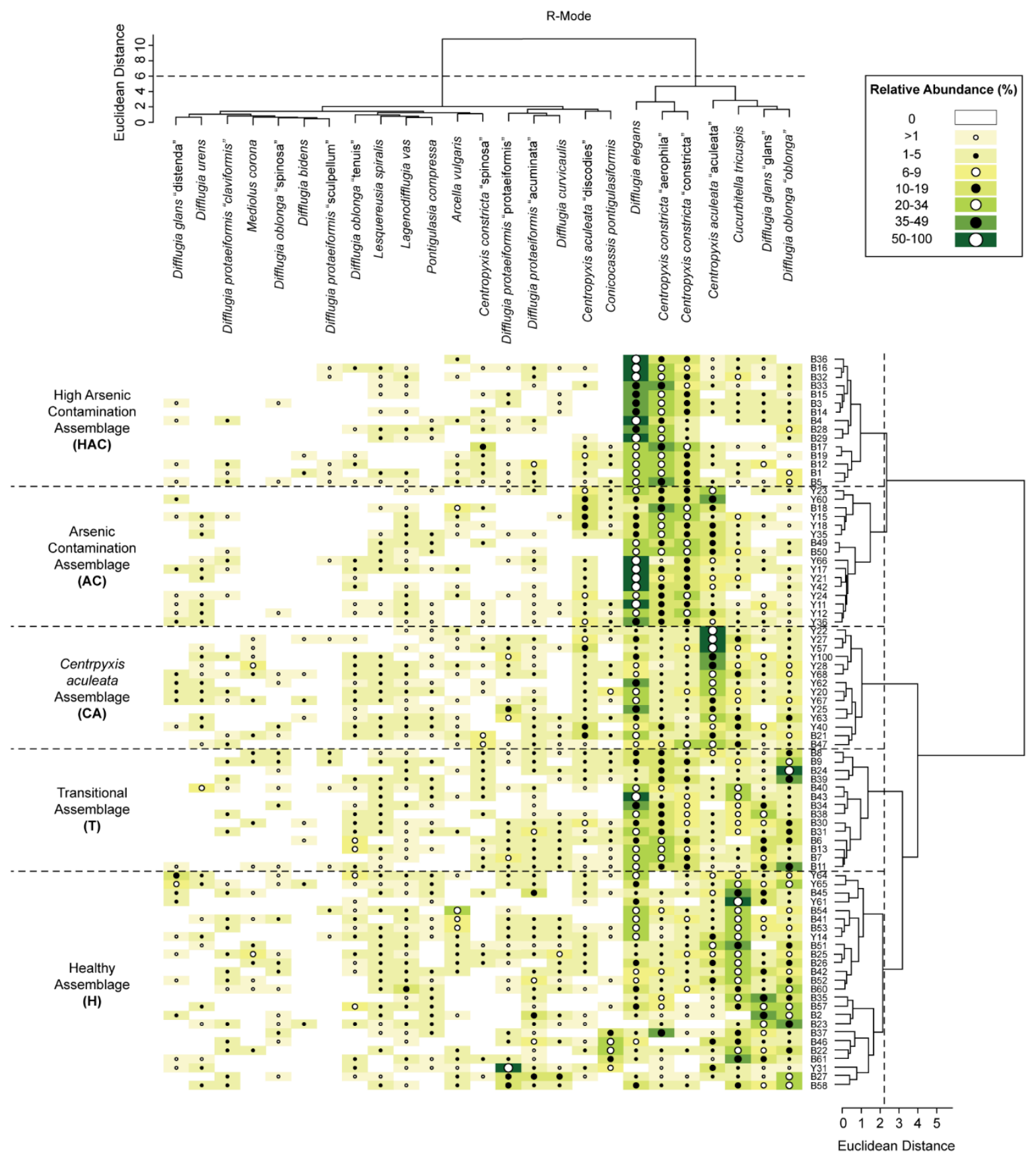

Figure 4. 4: Combined Q-mode and R-mode cluster dendrogram for the 84 samples and 25 statistically significant species and strains. Five faunal assemblages are indicated. 


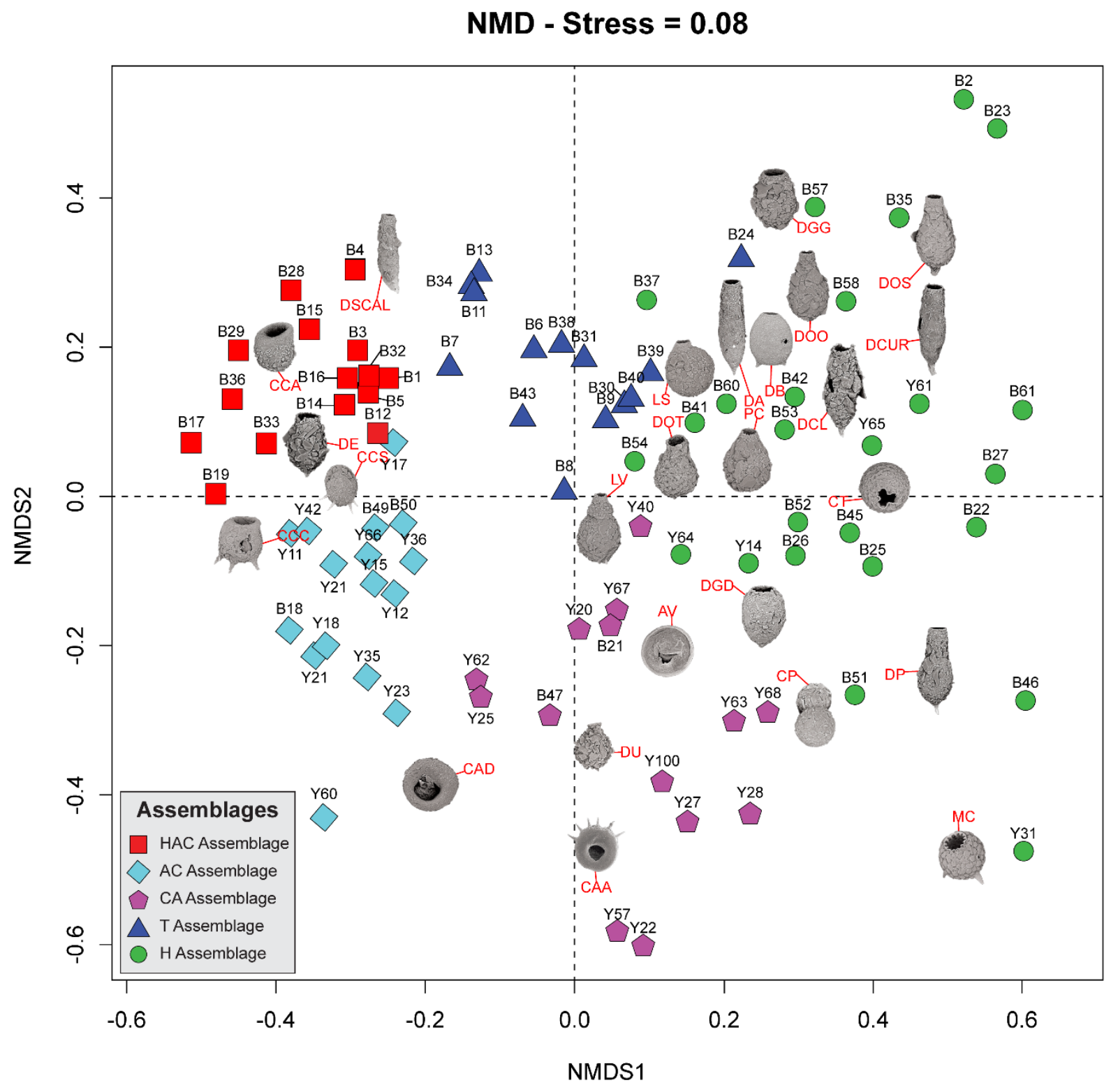


Figure 4. 5: None-Metric Multidimensional Scaling (NMDS) bi-plot. AV Arcella vulgaris, CAA - Centropyxis aculeata "aculeata", CAD - Centropyxis aculeata "discoides", CCA - Centropyxis constricta "aerophila", CCC Centropyxis constricta "constricta", CCS - Centropyxis constricta "spinosa”, CP Conicocassis pontigulasiformis, CT - Cucurbitella tricuspis, MC - Mediolus corona, DB - Difflugia bidens, DOO - Difflugia oblonga "oblonga", DOS Difflugia oblonga “spinosa”, DOT - Difflugia oblonga "tenuis", DGG - Difflugia glans "glans", DGD - Difflugia glans "distenda”, DU - Difflugia urens, DE Difflugia elegans, DPP - Difflugia protaeiformis "protaeiformis", DPAC Difflugia protaeiformis "acuminata", DPCl - Difflugia protaeiformis “claviformis", DCUR - Difflugia protaeiformis "curvicaulis", DPSC - Difflugia protaeiformis “scalpellum”, LS - Lesquereusia spiralis, LV - Lagenodifflugia vas, PC - Pontigulasia compress. 
response to ten significant environmental parameters (As, S1 carbon, sulfur [S], sodium [Na], calcium [Ca], distance to Giant Mine, phosphorous [P], barium [Ba], mercury $[\mathrm{Hg}]$, and total organic content [TOC])identified by using partial RDA analysis that explain $\sim 40 \%$ of the variance in the arcellinidan distribution (Figure 4.6). Arsenic (9.4\%) and S1-carbon (8.9\%) exert the most influence over the composition of the identified assemblages and collectively explain $18.3 \%$ of the total variance. A detailed description of the location, taxonomic composition, and primary environmental controls for each assemblage is provided in Appendix C $(7 \cdot 3 \cdot 2)$.

\subsubsection{Controls over the Distribution of Arcellinida}

The RDA and pRDA results in Figure 4.6 show that As is the dominant control on the distribution of Arcellinida. Stress-tolerant taxa such as D. elegans, and $C$. constricta strains 'aerophila' and 'constricta' dominate in $\mathrm{HAC}$ and $\mathrm{AC}$ assemblages (SDI range $=1.4-2.2$ ). This is a response to the elevated sediment As levels (median As $=290.4 \mathrm{ppm} ;$ range $=21.1-10000 \mathrm{ppm} ; n=31$ ), which in turn is attributed to the downwind location (93.5\% of lakes located to the west or north; $n=28$ ) and close proximity to the historic Giant Mine roaster stack as a point source of As contamination (median distance to Giant Mine roaster stack $=9.85$ $\mathrm{km} ; n=31$ ). Levels of As were notably lower in samples associated with the CA assemblage (median As $=258.1 \mathrm{ppm} ;$ range $==33.4-921.1 \mathrm{ppm} ; n=14$ ), even though such lakes were relatively close to the mine (median distance to Giant Mine roaster stack $=6.6 \mathrm{~km} ; n=14)$. Most $(57 \% ; n=8)$ of the lakes hosting this 


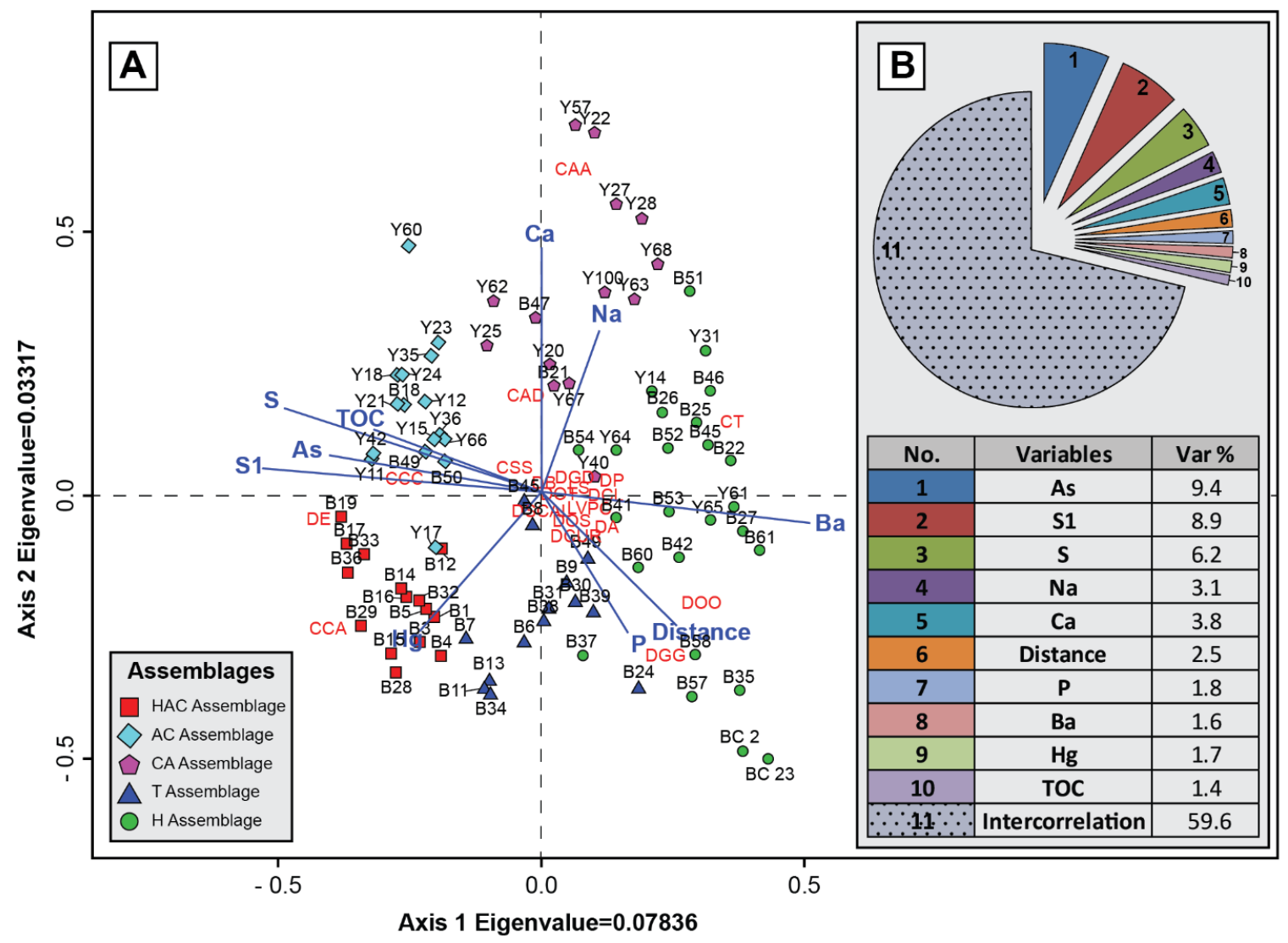

Figure 4. 6: Redundancy Analysis (RDA) species-environment-sample tri-plots for the 84 sediment-water-interface samples that yielded statistically significant arcellinidan populations and had no missing values. The five identified Arcellinida assemblages are: 1) the high As contamination assemblage (red square); 2) As contamination assemblage (light blue diamond); 3) Centropyxis aculeata assemblage (purple pentagon); 4) transitional assemblage (blue triangle); and 5) healthy assemblage (green circle). 
assemblage were located upwind of the roaster, while the remaining lakes (43\%; $n=6)$ are situated downwind from the mine site (Figure 4.1). The reduction in As levels is associated with a moderately diverse assemblage (SDI $=1.3-2.5$; median SDI $=2$ ) that is characterized by the emergence of $C$. aculeata "aculeata" as a dominant member, a notably lower number of stress-indicating taxa, and a slight elevation in the number of healthy-lake species and strains (e.g. C. tricuspis, D. oblonga "oblonga" and D. glans "glans"). With greater distance from the Giant Mine site, the stress-indicating $\mathrm{HAC}$ and $\mathrm{AC}$ assemblages were less common and the lakes became dominated by a transitional assemblage $(\mathrm{T}$; SDI $=1.6-2.5$; median SDI $=2.1$ ) that is comprised of lower proportions of stress-indicating species and higher numbers of healthy-lake indicating Arcellinida taxa. This result was expected since the transitional assemblage was observed most commonly in relatively distal lakes (median distance to Giant Mine roaster stack $=12.6 \mathrm{~km} ; n=$ 14) and characterized by moderate to low As levels (median As $=76.5 \mathrm{ppm}$; range $=16.1-740.7 \mathrm{ppm} ; n=14)$. The healthiest arcellinidan assemblage $(\mathrm{H} ; \mathrm{SDI}=1.7-$ 2.4; median SDI $=2.1$ ) was found in lakes $>10 \mathrm{~km}$ from the mine site (median distance $=19.6 \mathrm{~km} ; n=25)$ in lakes characterized by the lowest As concentrations (median As $=30.3 \mathrm{ppm} ;$ range $=6.3-905.2 \mathrm{ppm} ; n=25$ ). The observed faunal shift from stressed to healthy assemblages suggest well defined zones of impact (radius of $\sim 20 \mathrm{~km}$ around Giant Mine) and immediate impact (radius of $\sim 10 \mathrm{~km}$ around Giant Mine), which are consistent with the geospatial extent of the zones delineated by Palmer et al., (2015) and Galloway et al., (2017) $17 \mathrm{~km}$ and $11 \mathrm{~km}$, respectively). 
As with As, RDA and pRDA results indicate that the labile fraction of total organic matter (S1-carbon) is significant control over the distribution of Arcellinida taxa in area lakes (Figure 4.6). The RDA tri-plot shows that S1-carbon and As are closely correlated, which is corroborated by a significant positive Spearman's Rank correlation between the two variables $\left(r_{s}=0.5\right.$; Figure 6, Supplementary Table 4.2). It is notable that the arcellinidan response to the spatial variability of S1-carbon was similar to that observed with the As concentrations. The highest average levels of S1-carbon in HAC (median S1-carbon $=50.4 \mathrm{HC} / \mathrm{g}$ rock; range $=33.9-66.5 \mathrm{HC} / \mathrm{g}$ rock; $n=15$ ) and AC assemblages (median S1-carbon $=53.2 \mathrm{HC} / \mathrm{g}$ rock; range $=34.8-59.8 \mathrm{HC} / \mathrm{g}$ rock; $n=16$ ) are associated with elevated levels of As and the dominance of stress-indicating taxa. The lowest median S1-carbon values are associated with low As levels and healthy lake taxa (HA; median S1-carbon = 18.9 HC/g rock; range = 0.4-36.4 HC/g rock; $n=25)$. Previous studies have similarly reported high organic matter content in metalcontaminated soils (Valsecchi et al., 1995; Kelly and Tate, 1998) and lakes (Gough et al., 2008; Gough et al., 2010). The relationship between organic matter and As may reflect: 1) organic matter mediatiation of redox transformation of $\mathrm{As}^{5+}$ to $\mathrm{As}^{3+}$ and subsequently release or sorbed As into sediment pore water and the overlying water column (Van den Berghe et al., 2017); 2) competition with As over for sorption sites (Redman et al., 2002); or 3) enhancement of As sequestration by providing an organic substrate with a large surface area for metal(loid)-organic matter complexation (Grafe et al., 2001). Galloway et al. (2017) reported a significant association between As, S1-carbon and S in Yellowknife area lakes. The relationship was interpreted to reflect S1-carbon as an organic substrate suitable 
for microbial growth, which in turn mediated the authigenic precipitation of As derived from roaster emission to As sulfides. The similar arcellinidan response to both variables in this study suggests that both influence faunal ecology.

While phosphorus (P) explains a small portion of the variance in Arcellinida distribution (1.8\%), spatial variability of $\mathrm{P}$ in the study area seems to follow a relatively modest trend of increasing concentrations in distal lakes (median $\mathrm{P}=$ $1060 \mathrm{ppm}$; median distance $=16.7 \mathrm{~km} ; n=39$ ) compared to lakes closer to the Giant Mine (median $\mathrm{P}=880 \mathrm{ppm}$; median distance $=8.1 \mathrm{~km} ; n=45)$. As expected, the RDA tri-plot shows that $\mathrm{P}$ is positively associated with distance from the Giant Mine, and negatively with As and S1-carbon (Figure 4.6). While organic matter is a limiting factor for bacterial growth, an increasing number of studies have documented the importance of several elements, particularly $\mathrm{P}$, in controlling bacterial growth efficiency and attainable biomass within a wide range of aquatic systems (Toolan et al., 1991; Elser et al., 1995; Gurung and Urabe, 1999). In addition, the availability of $\mathrm{P}$ has been shown to influence As toxicity to primary producers in freshwater systems (Levy et al., 2005; Wang et al., 2013). Arsenate $\left(\mathrm{AsO}_{4}^{3-}\right)$ and phosphate $\left(\mathrm{PO}_{4}^{3-}\right)$ are chemically analogous. This similarity allows arsenate to substitute for phosphate, when the availability of the latter is low, and pass into the cell via phosphate transporters and inhibit phosphorylation, which consequently impacts several protein functions and cellular growth (Meharg and Macnair, 1991). Therefore, the slightly reduced proportions of $\mathrm{P}$ in lakes closer to Giant Mine may play a role in intensifying As toxicity to microbial and arcellinidan communities and as a result influence their distribution. 


\subsubsection{Interaction between Arcellinida, As and S1}

Healthy and active microbial communities thrive within organic substrates, especially the labile fraction (i.e. S1-carbon; Sanei et al., 2005). The development of such communities may provide an adequate source of nourishment for Arcellinida, which feed on bacteria, algae and fungi (Nikolaev et al., 2005). However, As is known to be toxic to most bacteria, except As-tolerant strains, as it can inhibit basic cellular functions linked to energy metabolism, basal respiration and enzyme activities (Baath, 1989; Walker et al., 2000). The effects of As toxicity have also been shown to be associated with a significant reduction in the microbial biomass in soil (Maliszewska et al., 1985; Hiroki, 1993; Simon, 2000), and, to a lesser extent, in lacustrine environments (Gough et al., 2008; Gough et al., 2010). Such a reduction in microbial biomass may induce sufficient environmental stress to impact nutrition-sensitive arcellinidan taxa (e.g. C. tricuspis and D. oblonga "oblonga") as competition for dwindling food resources intensifies. An experimental study by Burnskill et al (1980) suggests that As may inhibit the activity of organic matter-reducing bacteria during the winter, while exerting no influence on bacterial productivity in the summer. A recent study by Palmer et al. (2019) in the Yellowknife area has reported elevated levels of As $5^{+}$in surface waters during the summer when oxic conditions are dominant, and higher concentrations of $\mathrm{As}^{3+}$ during the winter when ice cover results in reducing conditions. Such seasonal inhibition may lead to a reduction in microbial biomass and a concurrent buildup of organic matter during the winter, which may decompose during the summer upon the recovery of microbial activities. A similar positive correlation 
between higher proportions of organic matter, represented by TOC, and elevated concentrations of heavy metal contamination have been reported by several studies (Kelly and Tate, 1998; Valsecchi et al., 1995; Gough et al., 2008). TOC is relatively high in our study (median $=25.6 \%$ ), which may explain the association of stress-tolerant taxa with high levels of As, S1-carbon, and TOC, and less tolerant species with relatively lower As, S1-carbon, and TOC levels in our study. Based on our results we propose a mechanism whereby As has an indirect influence over the spatial distribution of Arcellinida in the study area through suppression of growth of their food resource (i.e. microbial communities).

The introduction of a contaminant into an aquatic system may directly or indirectly impact biota. Direct influences can increase mortality rates through toxicity and reduce populations, while indirect effects may either decrease (e.g., by limiting sources of nourishment) or increase (e.g., by lowering competition over food sources) the population. Unfortunately, studies designed specifically to assess the direct and indirect influence of As on Arcellinida are lacking. The results of this study provide information that explains indirect impacts of As on arcellinidan trophic function but this does not preclude a direct impact of As toxicity on Arcellinida in the Yellowknife area.

\subsubsection{Tolerance of Arcellinida Taxa to As}

In environmentally stressed lakes, the biotic components often display a range of tolerances in response to the introduction of contaminants into the system (Negro and de Hoyos, 2005). For instance, contamination is often associated with a 
massive reduction in the biomass of intolerant species, while resilient taxa may show little indication of ecological stress, and may in fact expand to fill the ecological void. Such variation in tolerance was captured by the WATO analysis performed on the 25 Arcellinida taxa, which exhibited a wide tolerance to changes in As concentration (Figure 4.7, Supplementary Table 4.6). The optima values and upper tolerance limits exhibited a modest increasing trend accompanied by a taxonomic gradient from steno-metalloid (As) species (e.g. healthy lake taxa) to highly eury-metalloid (As) Arcellinida (e.g. stressed lake taxa). This association is in agreement with the findings of studies linking the abundance of healthy-lake and stressed-lake arcellinidan taxa to low or high levels of As, respectively (Patterson et al., 1996; Reinhardt et al., 1998; Nasser et al., 2016). However, the identification of robust As indicator species depends on quantitative characterization of species with both well-defined ecological optima and narrow tolerance ranges (Negro and de Hoyos, 2005). While the results of the analysis define the optima and upper tolerance As values for each identified taxa, none were identified with a lower As tolerance level higher than o ppm. This result is expected as all identified Arcellinida taxa are considered to be common members of any assemblages inhabiting substrates characterized by low to no As.

While it was not possible to identify any individual high concentration steno-metalloid (As) indicator species in our study, the results of the WATO method reveal three groupings of taxa that reflect certain As concentration ranges: (1) "moderate tolerance group" (MTG; As range = 0-350 ppm); (2) "high tolerance group" (HTG; As range = 360-76o ppm); and (3) “extreme tolerance group" (ETG; As range $=>750 \mathrm{ppm}$; Figure 4.7). The MTG includes 12 arcellinidan species and 


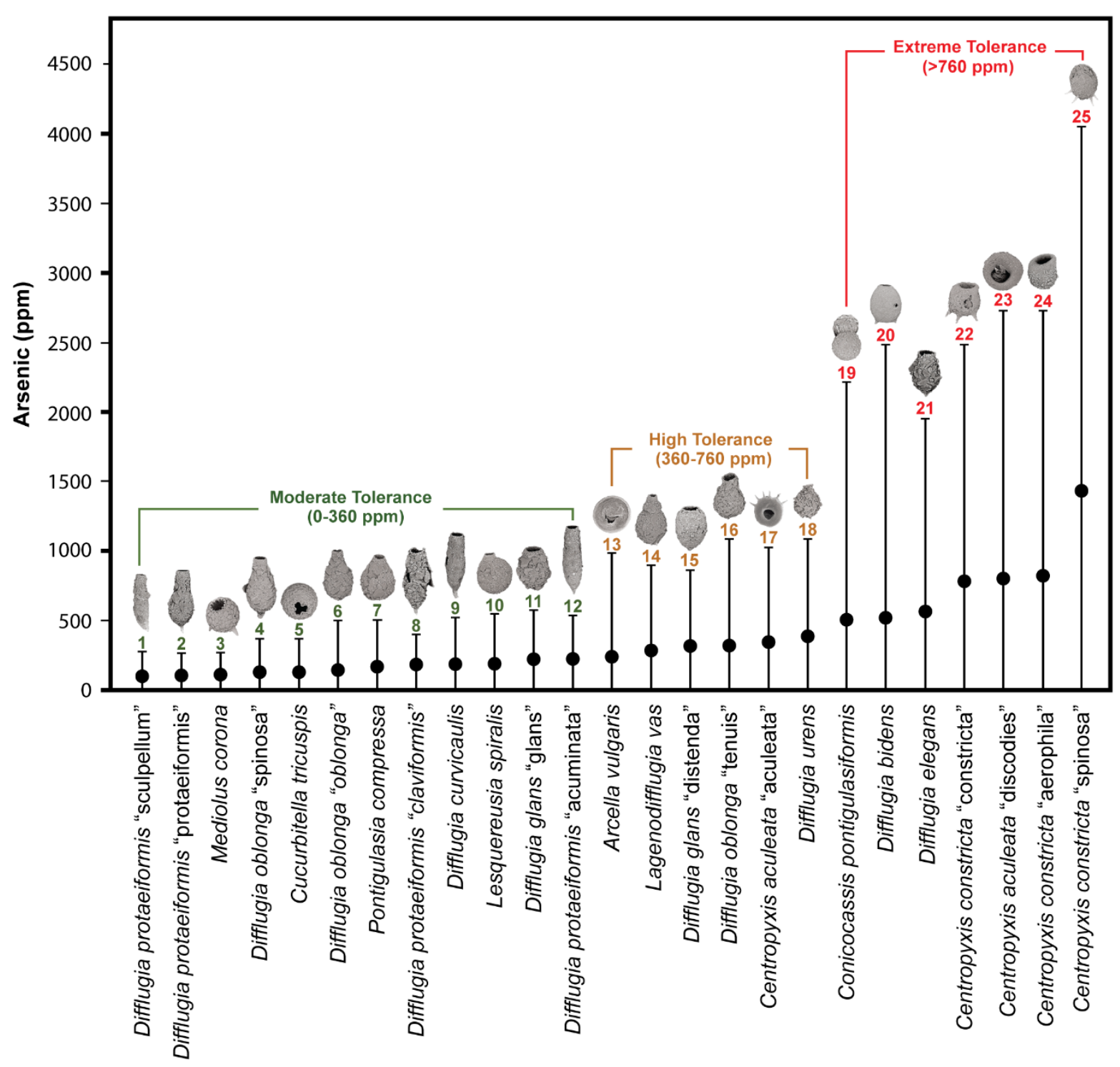

Figure 4. 7: Results of the Weighted Average Tolerance and Optima Analysis (WATO) on the 25 statistically significant arcellinidan taxa. 
strains with a relatively low to moderate As optima (99.3-225 ppm) and upper tolerance As range of 156.7-355.5 ppm. The species composition of the MTG is primarily represented by Difflugia $(n=8)$ species and C. tricuspis, which are known to be abundant in relatively healthy lakes (Patterson et al., 1996; Neville et al., 2010). Therefore, members of this group are likely to be characteristic of assemblages from lakes were As levels do not exceed $360 \mathrm{ppm}$.

Species comprising the ETG are characterized by well-known stresstolerant taxa (e.g. centropyxid species and stains and D. elegans), elevated optima range (507-1433.6 ppm) and upper tolerance range $(1382.5-2613.5 \mathrm{ppm})$. Centropyxid species and strains are known for their opportunistic nature and ability to withstand a variety of severely stressed environmental conditions (Medioli and Scott, 1983). In addition, D. elegans was previously reported (as D. protaeiformis "amphoralis") as being abundant in substrates with high As concentration (300-2100 ppm; Reinhardt et al., 1998). Therefore, arcellinidan assemblages dominated by these species are likely to be present under a wide range of As levels, but expected to dominate when levels of As are extremely elevated (>750 ppm). The HTH (360-760 ppm), spanning As concentrations between the MTG and ETG, is composed of six species (A. vulgaris, L. vas and D. urens) and strains (D. glans "distenda", D. oblonga "tenuis" and C. aculeata "aculeata"). These taxa include representatives of both the Difflugia-dominated MTG and Centropyxid-dominated ETG. This explains why there is an overlap of As tolerance between the HTH [As optima (241-387.3 ppm] and upper tolerance limits [540.7765.7 ppm]) and both the MTG and ETG. Since the HTH is found both in lakes 
where As levels are below $360 \mathrm{ppm}$ and those with As concentrations between 360$760 \mathrm{ppm}$, it is a generally less useful As indicator than the MTG and ETG.

\subsubsection{Paleoenvironmental Assessment Tool}

The reliability of using the identified Arcellinida As tolerance groups to infer temporal changes in As levels in impacted lakes was assessed on a test dataset comprising arcellinidan assemblages and As concentrations (measured by ICPMS) from 30 subsamples from a freeze core collected from Frame Lake, Northwest Territories, Canada (Gavel et al., 2018). We hypothesized that As ranges inferred by the relative abundance of taxa in the three tolerance groups derived from the inter-lake data set would represent measured total As concentrations from each core subsample in which As was independently measured using ICP-MS. Frame Lake sediments represented ideal test material as the well documented system was initially impacted by As contamination, then nutrient loading, and overprinted by redox-influenced remobilization of As upwards the stratigraphic column (Gavel et al., 2018). Our results show that the measured As levels in $66.6 \%$ of the samples ( $n=20$ ) where remobilization of As fell within the As range suggested by the bioindicator groupings (Figure 4.8; Supplementary Table 4.6b). The identification of an MTG assemblage (0-350 ppm As) in 16 samples was in line with measured As concentrations of $121.5-278 \mathrm{ppm}$. In addition, four samples characterized by very high levels of As (913.2-1473.5 ppm) were dominated by the ETG members. The two model mismatches (FL21, FL22), which were dominated by high proportions of As-tolerant taxa (i.e. HTG and ETG members), although their 


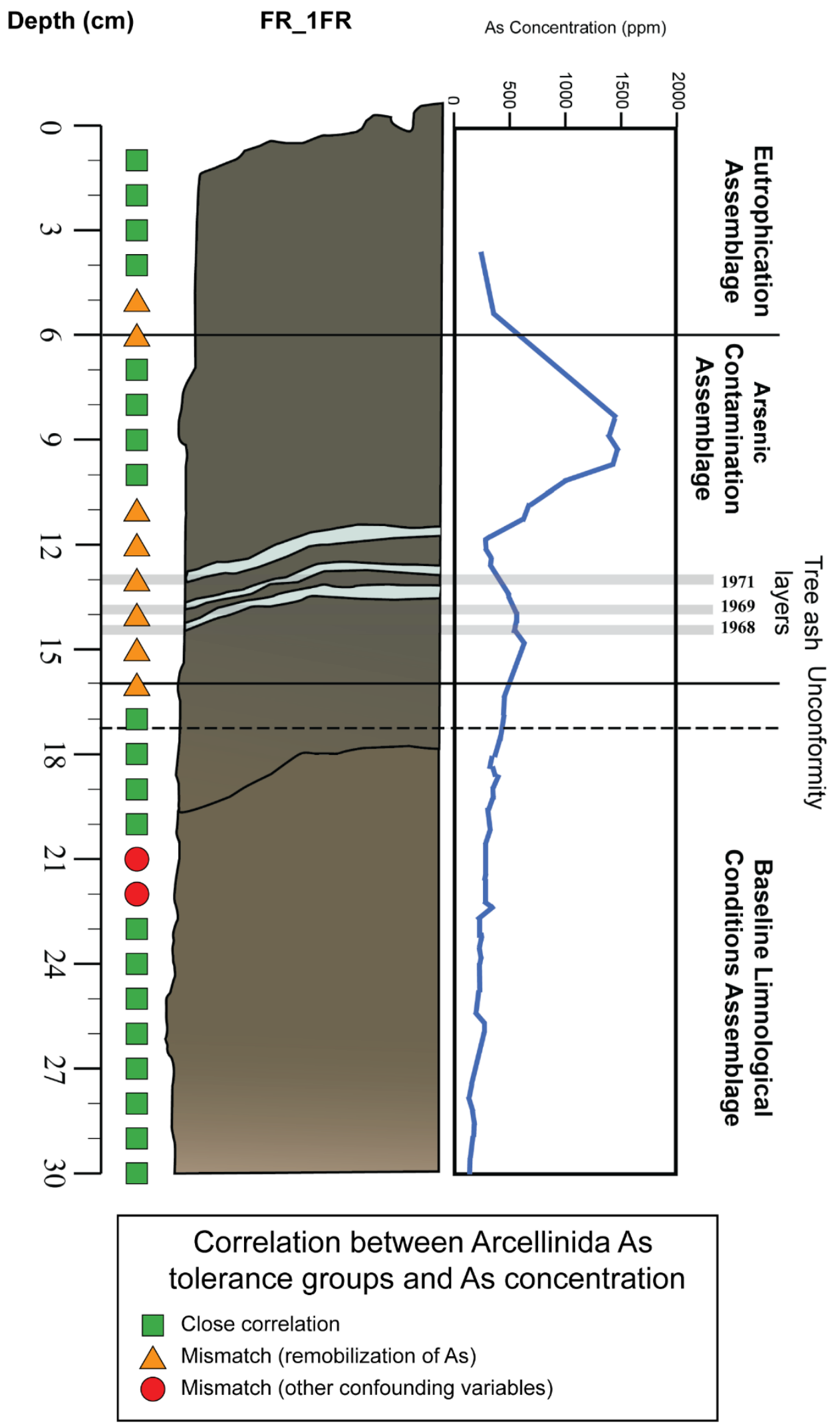


Figure 4. 8: The correlation between Arcellinida As tolerance group and As concentrations of 30 freeze core samples from Frame Lake. The strength of the correlation is represented by three colored symbols, with the green square representing a strong correlation, the orange triangle representing a mismatch (weak correlation) due to the influence of As remobilization, and the red circle representing a mismatch due to the influence of other confounding variables (modified after Gavel et al., 2018). 
measured As concentrations were below $350 \mathrm{ppm}$, which may be indicative of postdepositional remobilization of As out of these horizons (Supplementary Table 4.6b). Unidentified confounding environmental stressors may have also contributed to the observed fauna in these samples. The mismatches between the arcellinidan fauna and As concentrations in the other eight samples were a result of variable redox conditions, which resulted in As remobilization (Gavel et al., 2018). This result highlights the utility of these bioindicators as a tool to reconstruct As concentrations in sedimentary records, since the non-mobile arcellinidan assemblages provide a faithful paleoenvironmental record of As contamination at the time of deposition, regardless of any post-depositional remobilization of As.

\subsection{Conclusion}

Arcellinidan taxa $(n=25)$ in 84 sediment-water interface samples from the Yellowknife area responded to a decline in As concentrations further from the Giant Mine site by shifting from stressed assemblages near the mine to healthier assemblages in distant lakes $(>10 \mathrm{~km})$, thus corroborating the geographic extent of the airborne As contamination zone of immediate impact delineated by Palmer et al. (2015) and Galloway et al. (2017). These results establish the utility of arcellinidan bioindicators as an independent proxy for monitoring changes in As concentrations and the ecological health in lakes impact by mine-induced As contamination. The results also show that arcellinidan groups $(n=2)$, based on As-tolerance limits, can be used to successfully infer As concentrations in 20 out 
of 30 freeze core samples impacted by mine-induced As regardless of As postdepositional remobilization. Faunal changes may provide insight into the nature of prevailing As species, with highly stressed assemblages likely thriving when the more toxic tri-valent $\mathrm{As}^{3+}$ is dominant, while less-stressed assemblages likely associated with relatively less toxic penta-valent $\mathrm{As}^{5+}$ and more inert organic forms. Such insight is a significant as accurate geochemical determination of concentrations of particular As species is a metric not captured during typical industry standard ICP-MS analysis. However, more research investigating direct and indirect effects of As contamination on Arcellinida and identify different As uptake mechanisms and pathways is required to validate the use of group as a tool for inferring the dominant As species in lakes sediments. Nevertheless, Arcellinida show great potential as a robust reconnaissance tool for identifying impacted lakes where As concentrations may be elevated prior to conducting As speciation geochemical analysis. The findings generated in this study have broad application to other As-impacted lacustrine systems and will provide valuable information to policy makers, environmental planners, mine developers, as well as potentially facilitating rehabilitation efforts in lakes impacted by As contamination.

\subsection{Acknowledgements}

Funding for this research project was provided by a NSERC Discovery Grant to RTP as well as a NSERC Strategic Project Grant, a Department of Aboriginal and Northern Affairs Cumulative Impact Monitoring Program grant, and a Polar Knowledge grant awarded to JMG and RTP. This project was also supported by 
the Geological Survey of Canada, Environmental Geoscience Program (JMG). Additional direct and in-kind funding was provided by the Northwest Territories Geological Survey and Natural Resources Canada Polar Continental Shelf Program. NN is grateful for an NSTP grant. We thank the Organic Petrology and Sample Collection groups at GSC Calgary for sample curation, handling, and analyses.

\subsection{References}

Andrade CF, Jamieson HE, Kyser TK, Praharaj T, Fortin D, 2010. Biogeochemical redox cycling of arsenic in mine-impacted lake sediments and coexisting pore waters near Giant Mine, Yellowknife Bay, Canada. Applied Geochemistry 25:199-211.

Ardakani OH, Sanei H, Snowdon LR, Outridge PM, Obermajer M, Stewart R, Vandenberg R, Boyce K, 2016. The Accepted Values for the Internal Geological Survey of Canada (GSC) 9107 Rock-Eval 6® Standard (Upper Cretaceous Second White Speckled Shale, Colorado Group). Geological Survey of Canada, Western Canada (Open File 8043, 9 p).

Azcue JM, Mudroch A, Rosa F, Hall G, 1994. Effects of abandoned gold mine tailings on the arsenic concentrations in water and sediments of jack of Clubs Lake, B.C. Environmental Technology (United Kingdom) 15(7):669678. 
Brunskill GJ, Graham BW, Rudd JWM, 1980. Experimental Studies on the Effect of Arsenic on Microbial Degradation of Organic Matter and Algal Growth. Canadian Journal of Fisheries and Aquatic Science 37:415-423.

Baath E, 1989. Effects of heavy metals in soil on microbial processes and populations (a review). Water, Air, Soil, Pollution 47:335-79.

Beyens L, Chardez D, 1995. An annotated list of testate amoebae observed in the Arctic between the longitudes $27^{\circ} \mathrm{E}$ and $168^{\circ} \mathrm{W}$. Archiv für Protistenkunde 146:219-233.

Borba RP, Figueiredo BR, Matschullat J, 2003. Geochemical distribution of arsenic in waters sediments and weathered gold mineralized rocks from Iron Quadrangle Brazil. Environmental Geology 44:39-520.

Bright DA, Dodd M, Reimer KJ, 1996. As in subArctic lakes influenced by gold mine effluent: the occurrence of organoAsals and "hidden" As. Sci. Total Environment 1996, 180:165-182.

Bullen W, Robb M, 2005. Socio-economic Contribution of Gold Mining in the Yellowknife Mining District, Chapter 4. In Gold in the Yellowknife Greenstone Belt, Northwest Territories: Results of the EXTECH III Multidisciplinary Research Project; Anglin; Falck; Wright; Ambrose, Eds.; Association of Canada, Mineral Deposits Division: Canada. 
Canadian Council of Ministers of the Environment (CCME), 1978. Appendix XXIII-Canadian water quality guidelines: Updates (June 1997), arsenic, bromacil, carbaryl, chlorpyrifos, deltamethin, and glycols. In: Canadian water quality guidelines, Canadian Council of Resource and Environment Ministers. Prepared by the Task Force on Water Quality Guidelines.

Canadian Council of Ministers of the Environment (CCME), 2002. Canadian Sediment Quality Guidelines for the Protection of Aquatic Life, in, Canadian Environment Quality Guidelines.

Carrie H, Sanei G, 2012. Stern Standardisation of Rock-Eval pyrolysis for the analysis of recent sediments and soils. Organic Geochemistry 46:38-53.

Carter HJ, 1856. Notes on the fresh water Infusoria of the island of Bombay. The Annals and Magazine of Natural History 18:221-249.

Cattaneo A, Couillard Y, Wunsam S, Courcelles M, 2004. Diatom taxonomic and morphological changes as indicators of metal pollution and recovery in Lac Dufault (Québec, Canada). Journal of Paleolimnology 32(2):163-175.

Caussy D, Priest ND, 2008. Introduction to As contamination and health risk assessment with special reference to Bangladesh. Reviews of Environmental Contamination 197:1-15.

Cousens BL, 2000. Geochemistry of the Archean Kam Group, Yellowknife greenstone belt, Slave Province, Canada. The Journal of Geology 108:181197. 
Core Team R, 2014. A Language and Environment for Statistical Computing. (Available at:). http://www.r-project.org

Couture RM, Gobeil C, Tessier A, 2008. Chronology of atmospheric deposition of arsenic inferred from reconstructed sedimentary records. Environmental Science and Technology 42:6508-6513

Dalby AP, Kumar A, Moore JM, Patterson RT, 2000. Preliminary survey of arcellaceans (thecamoebians) as limnological indicators in tropical Lake Sentani, Irian Jaya, Indonesia. Journal of Foraminiferal Research 30:135142.

Dixit SS, Dixit AS, Smol JP, 1989. Lake Acidification Recovery can be Monitored using Chrysophycean Microfossils. Canadian Journal of Fisheries and Aquatic Sciences 46:1309-1312.

Du Ling G, Chapagain SK, Dewispelaere M, Meer E, Kazama F, Tack FGM, Rinklebe J, Verloo MG, 2009. Presence and mobility of arsenic in estuarine wetland soils of the Scheldt estuary (Belgium). Journal of Environmental Monitoring 11:873-881.

Ehrenberg CG, Verbreitung und Einfluss des mikroskopischen Lebens in Su"dund Nord Amerika, 1843. Ko“nigliche Akademie der Wissenschaften zu Berlin Physikalische Abhandlungen 1841:291-446. 
Ehrenberg CG, 1832. Über die Entwicklung und Lebensdauer der Infusionsthiere, nebst ferneren Beitra"gen zu einer Vergleichung ihrer organischen Systeme. Königliche Akademie der Wissenschaften zu Berlin Physikalische Abhandlungen 1931:1-154.

Elser J, Stabler L, Hasset R, 1992. Nutrient limitation of bacterial growth and rates of bacterivory in lakes and oceans: A comparative study. Aquatic Microbial Ecology 9:105-110.

Environment Canada, 2019. National Climate Data and Information Archive, Canadian Climate Normals or Averages 1981-2010, Yellowknife A, Northwest $\quad$ Territories; $\quad$ Environment $\quad$ Canada <http://www.climate.weatheroffice.gc.ca> [accessed June 6, 2019].

Galloway JM, Palmer M, Jamieson HE, Patterson RT, Nasser, N, Falck, H, Macumber A. L, Goldsmith SA, Sanei H, Normandeau P, Hadlari T, Roe HM, Neville LA, Lemay D, 2015. Geochemistry of lakes across ecozones in the Northwest Territories and implications for the distribution of arsenic in the Yellowknife region. Part 1: Sediments; Geological Survey of Canada, Open File 7908, 50 p. + appendix, 1 .zip file.

Galloway JM, Sanei H, Patterson RT, Mosstajiri T, Hadlari T, Falck H, 2012. Total arsenic concentrations of lake sediments near the City of Yellowknife, Northwest Territories. Geological Survey of Canada, Open File 7037, 47 p.

Galloway JM, Swindles GT, Jamieson HE, Palmer M, Parsons MB, Sanei H, Macumber AL, Patterson RT, Falck H, 2017. Organic matter control on the 
distribution of arsenic in lake sediments impacted by $\sim 65$ years of gold ore processing in subarctic Canada. Science of the Total Environment 622:1668-1679.

Gavel MJ, Patterson RT, Nasser NA, Galloway JM, Hanna BW, Cott PA, Roe HM, Falck H. 2018. What killed Frame Lake? A precautionary tale for urban planners. PeerJ 6:e485o.

Gough HL, Dahl AL, Nolan MA, Gaillard JF, Stahl DA, 2008. Metal impacts on microbial biomass in the anoxic sediments of a contaminated lake. Journal of Geophysical Research: Biogeosciences 113(2)

Gough HL, Stahl DA, 2011. Microbial community structures in anoxic freshwater lake sediment along a metal contamination gradient. The ISME Journal 5(3):543-558.

Government of the Northwest Territories - Environment and Natural Resources, 2003. Environmental Guideline for Contaminated Site Remediation. Environmental Guidelines produced by the Environment Division (ED) of GNWT-ENR $39 \mathrm{p}$.

Grafe M, Eick MJ, Grossl PR, 2001. Adsorption of arsenate(V) and arsenite(III) on goe- thite in the presence and absence of dissolved organic carbon. Soil Science Society of America Journal 65:1680-1687. 
Gurung TB, Urabe J, 1999. Temporal and vertical difference in factors limiting growth rate of heterotrophic bacteria in Lake Biwa. Microbial Ecology $38: 136-145$.

Hiroki M, 1993. Effect of arsenic pollution on soil microbial-population. Soil Science and Plant Nutrition 39(2):227-35.

Jackson FJ, Lafontaine CN, Klaverkamp J, 1996. Yellowknife - Back Bay Study on metal and trace element contamination of water, sediment and fish; Joint Report of Indian and Northern Affairs Canada and Fisheries and Oceans Canada p 195 .

Jamieson H, 2014. Legacy of Mining and Processing Refractory Gold Ore at Giant Mine, Yellowknife, Northwest Territories, Canada. Reviews in Mineralogy and Geochemistry 79: 533-551.

Kelly JJ, Tate RL, 1998. Effects of heavy metal contamination and remediation on soil microbial communities in the vicinity of a zinc smelter, Journal Environmental Quality 27(3):609-617.

Kerr DE, Wilson P, 2000. Preliminary surficial geology studies and mineral exploration considerations in the Yellowknife area, Northwest Territories. Geological Survey of Cananada Current Research C3, p 8.

Kihlman SM, Kauppila T, 2012. Effects of mining on testate amoebae in a Finnish lake. Journal of Paleolimnology 47:1-15. 
Kruskal JB, 1964. Non-metric multidimensional scaling: A numerical method. Psychometrika 29:115-129.

Kumar A, Patterson RT, 2000. Arcellaceans (thecamoebians): new tools for monitoring long-term and short-term changes in lake bottom acidity. Environmental Geology 39:689-697.

Lafargue E, Marquis F, Pillot, D, 1998. Rock-Eval 6 applications in hydrocarbon exploration, production, and soil contamination studies Revue de l'Institut français du pétrole 53:421-437.

Levy JL, Stauber JL, Adams MS, Maher W, Kirby JK, Jolley DF, 2005. Toxicity, biotransformation, and mode of action of arsenic in two freshwater microalgae (Chlorella sp. and Monoraphidium arcuatum). Environmental Toxicology and Chemistry 24:2630-2639.

Maliszewska W, Dec S, Wierzbica H, Wozniakowska A, 1985. The influence of various heavy metal compounds on the development and activity of soil microorganisms. Environmental Pollution Series A 37:195-215.

Medioli FS, Scott DB, 1983. Holocene Arcellacea (Thecamoebians) from eastern Canada. Cushman Foundation For Foraminiferal Research special Publication 21,pp 63.

Meyers PA, Teranes JL, 2001. Sediment organic matter In: Last WM et al. (Eds), Tracking Environmental Change using Lake Sediment. Phys Geoch Meth 2:239-265. 
Murray M, 2002. Is laser particle size determination possible for carbonate-rich lake sediments? Journal of Paleolimnology 27:173-183.

Martin AJ, Pedersen TF, 2002. Seasonal and inter-annual mobility of As in a lake impacted by metal mining. Environmental Science and Technology $36: 1516-1523$

Nasser NA, Patterson RT, Roe HM, Galloway JM, Falck H, Palmer MJ, Spence C, Sanei H, Macumber AL, Neville LA, 2016, Lacustrine Arcellinina (testate amoebae) as bioindicators of arsenic contamination. Microbial Ecology 72:130-149.

Neville LA, McCarthy FMG, MacKinnon MD, Swindles GT, Marlowe P, 2011. Thecamoebians (testate amoebae) as proxies of ecosystem health and reclamation success in constructed wetlands in the oil sands of Alberta, Canada. Journal of Foraminiferal Research 41:230-247.

Nikolaev SI, Mitchell EAD, Petrov NB, Berney C, Fahrni J, Pawlowski J, 2005. The testate lobose amoebae (order Arcellinida Kent, 1880) finally find their home within Amoebozoa. Protist 156:191-202.

Negro AI, de Hoyos C, 2005. Relationships between diatoms and the environment in Spanish reservoirs. Limnetica 24:133-144. 
Oyarzun R, Lillo J, Higueras P, Oyarzun J, Maturana H, 2004. Strong arsenic enrichment in sediments from the Elqui watershed, Northern Chile: industrial (gold mining at El Indio-Tambo district) vs. geologic processes. Journal of Geochemical Exploration 84:53-64.

Palmer M, Galloway JM, Jamieson HE, Patterson RT. Falck H, Kokelj SV, 2015. The concentration of arsenic in lake waters of the Yellowknife area 15 years after the end of gold ore processing. Northwest Territories. Geological Survey Open File 16.

Parsons M, LeBlanc KWG, Hall GEM, Sangster AL, Vaive JE, Pelchat P, 2012. Environmental geochemistry of tailings, sediments and surface waters collected from 14 historic gold mining districts in Nova Scotia. Geological Survey of Canada Open File 7105 (326 p).

Patterson RT, Baker T, Burbridge SM, 1996. Arcellaceans (thecamoebians) as proxies of arsenic and mercury contamination in northeastern Ontario lakes. Journal of Foraminiferal Research 26:172-183.

Patterson RT, Fishbein E, 1989. Re-examination of the statistical methods used to determine the number of point counts needed for micropaleontological quantitative research. Journal of Paleontology 63:245-248.

Patterson RT, Kumar AA, 2002. review of current testate rhizopod (thecamoebian) research in Canada. Palaeogeography, Palaeoclimatology, Palaeoecology, 180: 225-251. 
Patterson RT, Lamoureux EDR, Neville LA, Macumber AL, 2013. Arcellacea (Testate Lobose Amoebae) as pH Indicators in a Pyrite Mine-Acidified Lake, Northeastern Ontario, Canada. Microbial Ecology 65:541-554.

Penard E, 1890. Etudes sur les rhizopodes d'eau douce. Memoires de la Société de physique et d'histoire naturelle de Genève 31, 1-230.

Pinard J, Pippa S, Maissan J, 2007. Eds. Yellowknife Wind Energy Pre-feasibility Report. For the Aurora Research Institute.

Prentice SV, Roe HM, Bennion H, Sayer CD, Salgado J, 2017. Refining the palaeoecology of lacustrine testate amoebae: insights from a plant macrofossil record from a eutrophic Scottish lake. Journal of Paleolimnology 60:189-207.

Redman AD, Macalady DL, Ahmann D, 2002. Natural organic matter affects arsenic speciation and sorption onto hematite. Environmental Science and Technology 36;2889-2896.

Reinhardt EG, Dalby AP, Kumar A, Patterson RT, 1998. Arcellaceans as pollution indicators in mine tailing contaminated lake near Cobalt, Ontario, Canada. Micropaleontol 44:131-148.

Risklogic Scientific Services Inc. (Risklogic), 2002. Assessment of Human Health Risks Posed by Arsenic Contamination in Yellowknife, N.W.T. Report submitted to Yellowknife Arsenic Soils Remediation Committee, Environment Canada, Northern Division, Yellowknife, N.W.T. 
Rosenzweig C, Casassa G, Karoly DJ, Imeson A, Liu C, Menzel A, Rawlins S, Root TL, Seguin B, Tryjanowski P, 2007. Assessment of observed changes and responses in natural and managed systems, p. 79-131. In Climate change 2007-impacts, adaptation and vulnerability. Contribution of Working Group II to the Fourth Assessment Report of the Intergovernmental Panel on Climate Change; Parry ML, Canziani OF, Palutikof JP, van der Linden PJ, Hanson CE, Eds. Cambridge University Press.

Ryu JH, Gao S, Dahlgren RA, Zierenberg RA, 2002. Arsenic distribution, speciation and solubility in shallow groundwater of Owens Dry Lake, California. Geochimica et Cosmochimica Acta 66(17):2981-2994.

Salzsauler KA, Sidenko NV, Sherriff BL, 2005. Arsenic mobility in alteration products of sulfide-rich, arsenopyrite-bearing mine wastes, Snow Lake, Manitoba, Canada. Applied Geochemistry 20(12):2303-2314.

Sanei H, Stasiuk LD, Goodarzi F, 2005. Petrological changes occurring inorganic matter from Recent lacustrine sediments during thermal alteration by Rock- Eval $^{\mathrm{TM}}$ pyrolysis. Organic Geochemistry 36:1190-1203.

Schuh CE, Jamieson HE, Palmer MJ, Martin AJ, 2017. Solid-phase speciation and post-depositional mobility of arsenic in lake sediments impacted by ore roasting at legacy gold mines in the Yellowknife area, Northwest Territories, Canada. Applied Geochemistry 91:208-220.

Simon T, 2000. The effect of nickel and arsenic on the occurrence and symbiotic abilities of native rhizobia. Rostlinna Vyroba 46(2):63-8. 
Ter Braak CJF, Barendregt LG, 1986. Weighted averaging of species indicator values: its efficiency in environmental calibration. Mathematical Biosciences 78:57-72.

Toevs GR, Morra MJ, Polizzotto ML, Bostick BC, Fendorf SE, Strawn DG, 2006. Metal(loid) diagenesis in mine-impacted sediment of Lake Coeur d'Alene, Idaho. Environmental Science Technology 40:2537-2543.

Toolan T, Wehr JD, Findlay S, 1991. Inorganic phosphorus stimulation of bacterioplankton production in a meso- eutrophic lake. Applied Environmental Microbiology 57:2074-2078.

USDHHS (US Department of Health and Human Services), 2007. Toxico- logical profile for arsenic. Atlanta7 Public Health Service, Agency for Toxic Substances and Disease Registry www.atsdr.cdc.gov/toxprofiles/tp2.pdf

Valsecchi G, Gigliotti C, Farini A, 1995. Microbial biomass, activity, and organicmatter accumulation in soils contaminated with heavy-metals. Biology Fertility Soils 20(4):253-259

Van Den Berghe MD, Jamieson HE, Palmer MJ, 2017. Arsenic mobility and characterization in lakes impacted by gold ore roasting, Yellowknife, NWT, Canada. Environmental Pollution 234:630-641.

van den Wollenberg AL, 1977. Redundancy analysis. An alternative for canonical correlation analysis. Psychometrika 42:207-219. 
van Hengstum P, Reinhardt E, Boyce JI, Clark C, 2007. Changing sedimentation patterns due to historical land-use change in Frenchman's Bay, Pickering, Canada: evidence from high-resolution textural analysis. Journal of Paleolimnology 37:603-618.

Yamashita K, Creaser RA, Stemler JU, Zimaro TW, 1999. Geochemical and Nd-Pb isotopic systematics of late Archean granitoids, southwestern Slave Province, Canada: constraints for granitoid origin and crustal isotopic structure. Canadian Journal of Earth Science 36:1131-1147.

Walker C, Goodyear C, Anderson D, Titball RW, 2000. Identification of Arsenic resistant bacteria in the soil of a former munitions factory at Lo"cknitz, Germany. Land Contamination and Reclamation 8(1):13-8.

Wang NX, Li Y, Deng XH, Miao AJ, Ji R, Yang LY, 2013. Toxicity and bioaccumulation kinetics of arsenate in two freshwater green algae under different phosphate regimes. Water Research 47:2497-2506.

Wang S, Mulligan CN, 2006. Occurrence of arsenic contamination in Canada: sources, behavior and distribution. Science of the Total Environment 366:701-721.

Ward JH, 1963. Hierarchical grouping to optimize an objective function. Journal of American Statistical Association 58:236-244. 


\section{Chapter 5}

\section{Intra-lake response of Arcellinida (testate}

\section{lobose amoebae) to gold mining-induced}

arsenic contamination in northern

\section{Canada: Implications for environmental}

\section{monitoring}

Nawaf A. Nasser ${ }^{1^{*}}$, R. Timothy Patterson ${ }^{1}$, Jennifer M. Galloway ${ }^{1,2,3}$, Hendrik Falck 4

${ }^{1}$ Ottawa-Carleton Geoscience Centre and Department of Earth Sciences, Carleton University, 1125 Colonel By Drive, Ottawa, Ontario, K1S 5B6, Canada

2 Aarhus Institute of Advanced Studies (AIAS), Aarhus University, Nordre Ringgade 1, Aarhus C, 800o, Denmark

${ }^{3}$ Geological Survey of Canada (GSC) / Commission géologique du Canada, Natural

Resources Canada (NRCan) / Ressources naturelles Canada (RNCan), 3303 - 33

Street N.W. Calgary, AB, T2L 2A7, Canada

4 Northwest Territories Geological Survey, 4601 52nd Ave, Yellowknife, Northwest Territories, X1A 2L9, Canada 


\subsection{Abstract}

Arcellinida (testate lobose amoebae) were examined from 40 near-surface sediment samples (top $0.5 \mathrm{~cm}$ ) from two lakes impacted by arsenic (As) contamination associated with legacy gold mining in subarctic Canada, to: 1) quantify the response of Arcellinida to intra-lake variability of As and other physicochemical controls; and, 2) evaluate whether the impact of As contamination derived from two former gold mines, Giant Mine (1938-2004) and Tundra Mine (1964-1968 and 1983-1986), on the Arcellinida distribution in both lakes is comparable or different. Cluster analysis and nonmetric multidimensional scaling (NMDS) were used to identify distinct Arcellinida assemblages in both lakes, while redundancy analysis (RDA) was employed to quantify the relationship between the identified assemblages, As, and other parameters. Interpretation of the cluster analysis and NMDS results revealed four distinct arcellinidan assemblages in Frame Lake (assemblages 1-4) and two in Hambone Lake (assemblages 5 and 6): 1) Extreme As Contamination (EAC) Assemblage; 2) High calcium (HC) Assemblage; 3) Moderate As Contamination (MAC) assemblages; 4) High Nutrients (HN) Assemblage; 5) High Diversity (HD) Assemblage; and, 6) Centropyxis aculeata (CA) Assemblage. RDA analysis shows that the faunal structure of the Frame Lake assemblages was controlled by five variables that explained $43.2 \%$ of the total faunal variance, with As (15.8\%), Olsen phosphorous (Olsen P; 10.5\%), and Ca (9.5\%) being the most statistically significant ( $p$-value < 0.004). Stress-indicating arcellinidan taxa were associated with elevated As concentrations (e.g. EAC and MAC; As concentrations range $=145.1-1336.6$ 
mg.kg-1; $n=11$ ), while stress-sensitive taxa thrived in relatively healthier assemblages found in substrates with lower As concentrations and higher concentrations of nutrients, such as Olsen $\mathrm{P}$ and $\mathrm{Ca}$ (e.g. HC and HM; As concentrations range $\left.=151.1-492.3 \mathrm{mg} \cdot \mathrm{kg}^{-1} ; n=14\right)$. In contrast, the impact of As on the arcellinidan distribution was not statistically significant in Hambone Lake (7.6\%; $p$-value $=0.152)$, where instead sedimentary variables such as the proportion of silt $(24.4 \% ; p$-value $=0.005)$ and loss-on-ignition-determined minerogenic content $(18.5 \%$; $p$-value $=0.021)$ explained a higher proportion of the total faunal variance (58.4\%). However, a notable decrease in arcellinidan species richness and abundance and increase in the proportions of stress-tolerant fauna near Hambone Lake's outlet (e.g. CA samples) is consistent with a spatial gradient of higher sedimentary As concentration near the outlet, and suggests a lasting, albeit weak, As influence on Arcellinida distribution in the lake. We attribute the disparity in the magnitude of As control, and the variance in arcellinidan response to As, to the dominance of a specific As mineral host in each lake, which is in turn a by-product of employing different ore-processing techniques at the former Giant (roasting) and Tundra mines (free-milling). The results of this study provide the quantitative evidence for the sensitivity of Arcellinida to intra-lake variations in As concentrations and demonstrate the reliability of using this group as a tool for monitoring the level of As contamination and the progress of remediation, and for discriminating the types of dominant As mineral forms in lake sediments.

Keywords: Arcellinida, lake sediments, arsenic, gold mining, intra-lake sampling, multivariate analysis 


\subsection{Introduction}

The mineral mining sector in northern Canada has been a substantial driver of the nation's economic growth, with a production value of $\$ 65$ billion since 1974 (NRCan, 2019). While highly profitable, many northern mines operated before the concept of sustainable development was introduced in 1987 (WCED, 1987). As a result, several mining operations introduced considerable levels of contaminants, mostly heavy metals, to surrounding environments and this poses a risk to environmental and human health (INAC, 2009; Silk, 2009). Gold mining, in particular, is a primary anthropogenic source of arsenic (As) contamination in the Northwest Territories (NT; e.g. Palmer et al., 2015, 2019; Galloway et al., 2012, 2015, 2017; Nasser et al., 2016; Miller et al., 2019). Orogenic greenstone belts in the NT (e.g. Yellowknife and Courageous Lake Greenstone Belts) host large gold deposits that are closely associated with As-bearing sulfides (e.g. arsenopyrite). Ore-processing at several gold mines across the NT, especially Giant Mine in the Yellowknife area (1938-2004; Figure 5.1A), left an enormous legacy of As contamination on and off these mine sites (e.g. INAC, 2009; Galloway et al., 2017, Miller et al., 2019). Environmental concerns related to legacy of As contamination spurred a number of remedial programs at several gold mine sites - e.g., Giant Mine, Discovery Mine (1949-1969), Hidden Lake Mine (1959-1969), and Tundra Mine (1964-1968 and 1983-1986; INAC, 2009; Silk, 2009) -to restore these sites and any impacted areas to a viable condition.

In 2002, the Crown Indigenous Relations and Northern Affairs Canada (CIRNAC) issued the Mine Site Reclamation Policy (MSRP) for the NT to enhance 


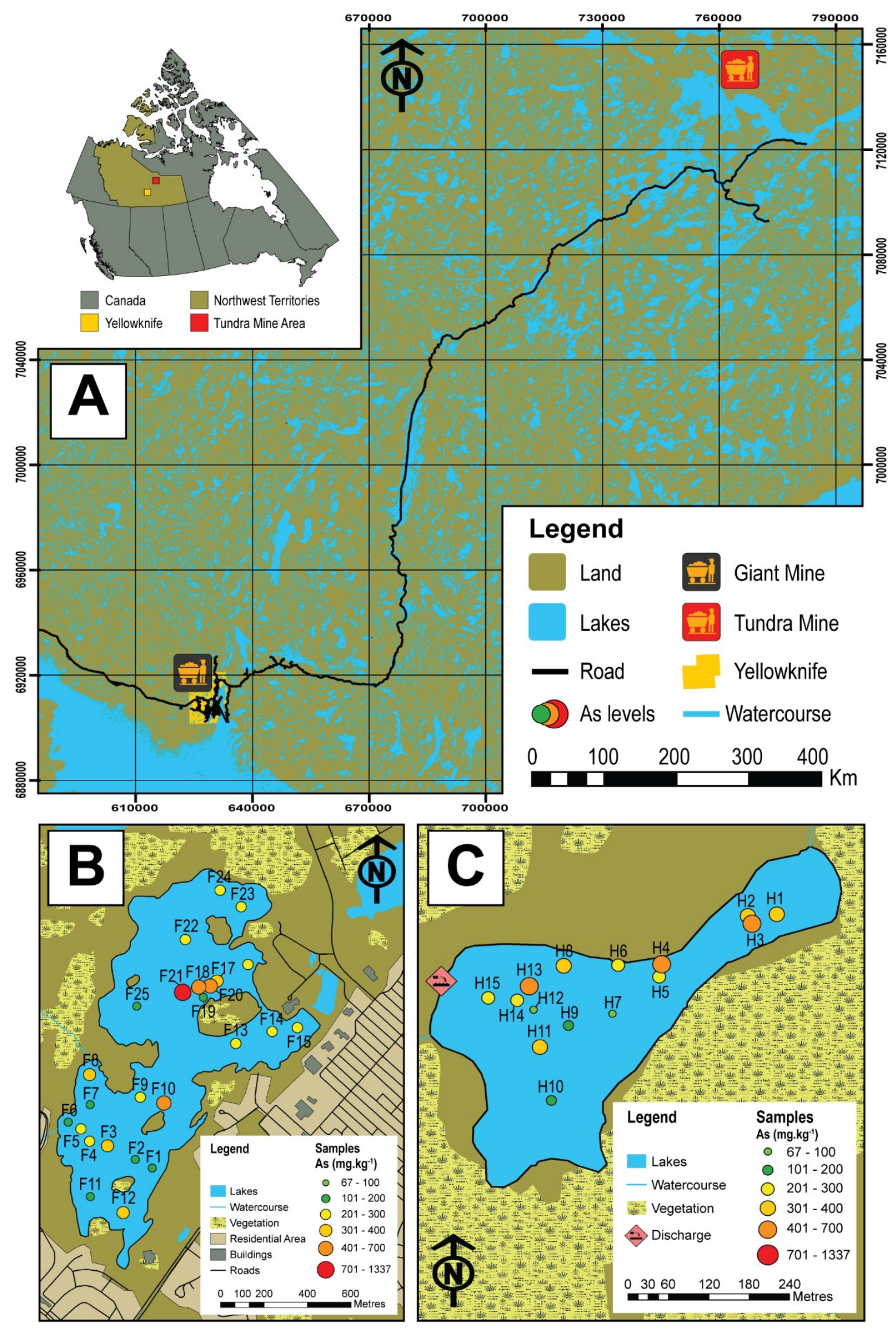


Figure 5. 1: Map of the study area and sampled lakes. (A) a map showing the study area in the central Northwest Territories, Canada and the locations of the historic Giant (black and yellow icon) and Tundra mines (red and yellow icon). (B) a map showing Frame Lake and the location of the 25 sampling stations. (C) a map showing Hambone Lake and the location of the 15 sampling stations. The colourcoded and graduated circles reflect the As concentration at each sampling station. 
the environmental sustainability of mineral resources development (INAC, 2002). The policy stipulates that developers/owners of new and existing mines Projects must: 1) always have a closure and reclamation plan; 2) rehabilitate any areas impacted by mining activities; and, 3) monitor the progress of remedial efforts at rehabilitated sites post mine closure (INAC, 2002). While the impact of legacy As contamination has adversely affected a wide range of environments in the NT, contamination of lacustrine sediments and surface waters by As is of particular concern due to the socio-economic and ecological significance of lakes. Such concerns are mostly attributed to the redox-sensitive nature of As, which allows this metalloid to vertically migrate within the sedimentary column and postdepositionally cycle between sediments and overlying waters (Toevs et al., 2006; Du Ling et al., 2009). As a result of this mobility, lake sediments can either sequester As, typically under oxic conditions, or release As from sediment to porewaters, and subsequently to overlying surface waters under reducing conditions (e.g., Palmer et al., 2019). In some high latitude lakes that experience frequent seasonal variability, including development of anoxia in winter under ice, this As cycling may be perpetual (Palmer et al., 2019). Monitoring programs focusing on lakes impacted by As contamination in the NT are often based on the collection and processing of lake sediment and water samples (e.g. SENES, 2011; Reid, 2012; AANDC, 2014; AECOM, 2015). An aspect that is usually overlooked by such programs is the biotic response to As contamination, especially that of benthic microfaunal communities (e.g. Nasser et al., 2016; Thienpont et al., 2016; Gavel et al., 2018; Sivarajah et al., 2019). 
Microbial benthic communities that preserve well in the sedimentary record have been shown to archive the impact of contamination on lacustrine ecosystems through time (e.g., Dixit et al., 1989; Cattaneo et al., 2004; Gavel et al., 2018), and therefore have the potential to be a reliable tool for monitoring the efficacy of remediation. Arcellinida, or testate lobose amoebae (Mitchell et al., 2008), are established bioindicators of change in lacustrine environmental conditions (Charman 2001; Patterson and Kumar, 2002). These benthic protozoans are abundant in the Quaternary deposits of fresh and brackish aquatic environments and are characterized by a broad geographical distribution that extends from the tropics to the Arctic (Medioli and Scott, 1988; Collins et al., 1990; Dalby et al., 2000; Charman 2001; Patterson, 2014; Patterson et al., 2015). Arcellinida taxa are

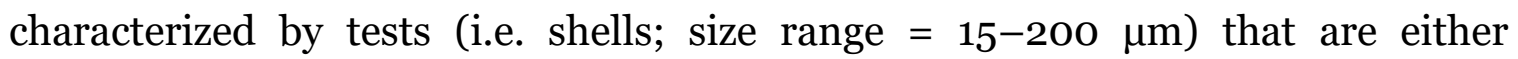
comprised of proteinaceous materials (autogenous tests) or assembled by agglutinating extraneous particles from the environment (xenogenous tests; Patterson and Kumar, 2002), with xenogenous tests being of more value in lacustrine studies owing to their high preservation potential.

The past 20 years have seen a growing interest in exploring the potential Arcellinida as bioindicators of anthropogenic contamination (e.g. Asioli et al., 1996; Kumar and Patterson, 2000; Neville et al., 2011; 2014; Kihlman and Kauppila, 2012). Studies by Patterson et al. (1996) and Reinhardt et al. (1998) were the first to confirm the sensitivity of Arcellinida to mine-derived As contamination at an intra-lake spatial scale in lakes from Ontario, Canada. Nasser et al. (2016) provided evidence of a strong quantitative relationship between Arcellinida assemblages and changes in sedimentary As concentrations in a regional spatial 
survey of near-surface sediments of 59 lakes in the Yellowknife area, NT. Recently, Gavel et al. (2018) demonstrated the sensitivity of Arcellinida assemblages to temporal increase in As concentrations, coeval with the onset of historic gold mining, in a freeze core from Frame Lake in the City of Yellowknife, NT. The sensitivity of Arcellinida to the spatio-temporal change in As levels coupled with their rapid reproduction and abundance in lake sediments makes the groups particularly useful for environmental monitoring and assessment of the progress of remedial efforts.

As lakes are generally characterized by heterogenous substrates and multiple sub-environments (Last and Smol, 2001), development of an appropriate sampling strategy is essential to ensure accurate environmental monitoring of the progress of remedial efforts in impacted lakes using Arcellinida population dynamics. A temporal sampling approach (e.g. Gavel et al., 2018), while beneficial for long-term environmental monitoring, is often limited by the number of sedimentary cores collected, and are often collected from the $Z_{\max }$ of a basin. In contrast, intra-lake sampling often targets multiple sites within a lake to maximize spatial coverage and to ensure the identification of faunal gradients that develop in response to local scale variability in As concentrations. An intra-lake sampling strategy is of course most suitable for monitoring the progress of remedial efforts within an impacted lake. However, the only two intra-lake investigations of arcellinidan response to As contamination (i.e., Patterson et al., 1996; Reinhardt et al., 1998), while successful in confirming the sensitivity of Arcellinida to As, involved a project design that only produced semi-quantitative results. Therefore, a quantitative assessment of the intra-lake response of Arcellinida distribution to 
sedimentary As concentration in near-surface sediment is required to further develop the group as a reliable tool for monitoring As contamination in lakes.

In this study, we examine Arcellinida species and strains in 40 surfacesediment samples from two lakes in the central NT with the aim of quantifying their response to intra-lake variability of As concentrations and other controls. The studied lakes are Frame Lake $\left(62.454^{\circ} \mathrm{N},-114.390^{\circ} \mathrm{E} ; n=25\right.$; Figure $\left.1 \mathrm{~B}\right)$, located within the City of Yellowknife, and Hambone Lake (64.046741 N, -111.156795 W; $n=15$ ) located $\sim 240 \mathrm{~km}$ northeast of the Yellowknife area (Figure 5.1C). These lakes are known to have elevated levels of As that are derived at least in part from the respective operations of the former Giant (Frame Lake) and Tundra gold mines (Hambone Lake), and are currently the target of ongoing remedial and environmental monitoring efforts (e.g. Frame Lake rehabilitation project, led by Tides Canada; Tundra Mine remediation project, led by CIRNAC). The ecological health of Frame Lake, once a prominent recreational site in the City of Yellowknife, deteriorated markedly in only a decade from the late 1960s onward due to encroaching urbanization, aerial fallout of As from roaster stack emissions of Giant Mine, and suspected illegal dumping of sediments (Gavel et al. 2018; Menard et al. 2019). Elevated As levels in Hambone Lake are derived from the operations of the nearby Tundra Mine, and are the result of weathering of mine tailings and seepage from tailings containment ponds near the lakes western shore (Reid 2012; Miller et al., in 2019). As the former Giant and Tundra gold mines have been shown to have introduced different As mineral forms to surrounding lakes (Galloway et al., 2017; Schuh et al., 2017; Miller et al., 2019), a secondary objective of this study is 
to assess whether the impact of As derived from these mines on Arcellinida distribution is similar, or different.

\subsection{Regional Setting}

\subsubsection{Frame Lake}

Frame Lake $\left(62.454^{\circ} \mathrm{N},-114.390^{\circ} \mathrm{E}\right)$ is a subarctic lake that is located near the downtown area of the City of Yellowknife (Figure 5.1B). The lake is underlain by rocks of the Yellowknife Supergroup of the southern Slave structural province of the Canadian Shield in the central NT, Canada (Cousens, 2000). Bedrock lithologies consists of Archean meta-volcanic and meta-sedimentary rocks intruded by younger granitoids (Siddorn et al., 2007). Surficial sediments in the study area are primarily comprised of a thin $(<2 \mathrm{~m}$ thick) discontinuous layer of till and Glacial Lake McConnell sediments (Kerr and Wilson, 2000). The till consists of a stony and loosely compacted matrix-supported diamicton (Smith, 1994; Kerr and Wilson, 2000) while the Lake McConnell sediments are comprised of poorly to moderately sorted coarse to fine sand, silt, and clay that can be up to $20 \mathrm{~m}$ thick in some topographic lows. Elevations in the study area rise gradually from $157 \mathrm{~m}$ above mean sea level at Great Slave Lake to $350-400 \mathrm{~m}$ above mean sea level north of Thistlethwaite Lake (Stubley, 1997). The low-relief terrain surrounding the Yellowknife area consists of rocky outcrops associated with glacial and glaciolacustrine sediments in topographic lows (Stubley, 1997). The study area has a continental subarctic climate with relatively cool and dry summers and winters that are cold and even dryer. Mean annual temperature is $-4 \cdot 3^{\circ} \mathrm{C}$ with a 
mean annual precipitation of $288.6 \mathrm{~mm}$ (Environment Canada, 2019). Prevailing wind blows from the east for most of the year except for the months of June, July, and August, when it blows out of the south (SENES Consultants Limited; 2005; Environmental Canada, 2019).

Frame Lake has a relatively small surface area (88.4 ha) with a maximum length and width of $1.75 \mathrm{~km}$ and $\sim 1 \mathrm{~km}$, respectively (Healey, 1973; Dirszowsky and Wilson, 2016). The lake has a maximum depth of $4.5 \mathrm{~m}$ in the southern basin and $5.5 \mathrm{~m}$ in the northern basin (Menard et al., 2019). In terms of morphology, Frame Lake is of an elongate shape (southwest-northeast trend) that widens toward the northeastern end of the lake (Figure 3.1B). Vegetation in the area around the lake includes conifers, paper birch and shrubs (Kerr and Wilson, 2000). Water derived from sheet wash or small ephemeral channels attributed to rainfall events and snowmelt are currently the primary source of inflow to Frame Lake (Dirszowsky and Wilson, 2016; Gavel et al., 2018). The lake's outflow is currently controlled by the opening and closing of a sluice gate in a causeway, located on the lake's eastern shore, which remains close most of the year (Gavel et al., 2018).

Before the 1970s, Frame Lake was an attractive recreational destination for residents and tourists alike (e.g. swimming at the McNiven bathing beach, and canoeing). The lake also used to serve as a fishing spot for the Yellowknives Dene, with both whitefish and pike being found (Tides Canada, 2015). However, historical mining activities in the area, especially that of Con (1938-1999) and Giant mines, coupled with the continuous urbanization of the City of Yellowknife, led to a severe decline in the ecological health of the lake (Dirszowsky and Wilson, 
2013, 2016; Gavel et al., 2018; Menard et al., 2019). The lake is currently targeted for remedial and monitoring efforts (e.g. Frame Lake rehabilitation project; Tides Canada, 2015) to restore lake conditions to a state that is compatible with environmental guidelines and human activities.

\subsubsection{Hambone Lake}

Hambone Lake (64.046741 N, -111.156795 W) is located within the former Tundra Mine property in the Courageous Lake region, approximately $240 \mathrm{~km}$ northeast of the City of Yellowknife (Figure 3.1C). The region is of low relief and is characterized by a gently rolling tundra that underlain by bedrock belonging to the Yellowknife Supergroup in the central portion of the Slave structural Province (Dillion-Leitch, 1981; Hatfield Consulting, 1982; Gibson and Reid, 2014). The volcanic lithologies of the Courageous Lake Greenstone Belt are unconformably on top of thin, discontinuous sequences of volcanic, clastic, and banded iron formations of the Central Slave Cover Group and the diorite and tonalite gneiss of the Central Slave Basement Complex, and are bordered by the Courageous Lake Batholith to the west and turbidite metasedimentary rocks to the east (Moore, 1951; Bleeker et al., 1999). Hambone Lake is situated within the Lockhart River drainage basin (catchment area $\sim 26,600 \mathrm{~km}^{2}$ ), which drains southward into Great Slave Lake (Topographical Survey of Canada, 1925). The climate of the study region is cold and dry with an average annual temperature of -12 to $-9^{\circ} \mathrm{C}$ (SENES Consultants, 2006). 
Hambone Lake is relatively small with a surface area of only 10.7 ha (711.4 $\mathrm{m}$ long and $292.5 \mathrm{~m}$ wide). The name of the lake is derived from its unique morphology that resembles a hambone with a wider southwestern section that tapers towards the northeast (Figure 3.1C). The lake is relatively shallow with an average depth of $1.5 \mathrm{~m}$ (maximum depth is $~ 2 \mathrm{~m}$; Gibson and Reid, 2014; Miller et al., 2019). Hambone Lake is well mixed in the open water season due to its shallow nature and the elevated frequency of high winds in the study area (Gibson and Reid, 2014). A drainage pathway from the Tundra Mine site, discharged from a mined tailings containment pond called Lower Pond passes directly through Hambone Lake and subsequently flows downstream through the lake's outlet to Powder Mag Lake, Sandy Lake, and ultimately discharging into Courageous Lake (Reid, 2012; Gibson and Reid, 2014).

Maintenance and care of the Tundra Mine site has been the responsibility of the Contaminants and Remediation Directorate of CIRNAC since 1999. The former mine site went through various remediation activities that started in 2007 and ended recently in 2018 (e.g. INAC, 2005; SENES Consultants, 2006, 2011; Lorax Environmental, 2007; AANDC, 2014; AECOM, 2015, 2018). Currently, the mine site is part of long-term monitoring program, which began following the completion of all remedial efforts in 2018 (AECOM, 2018). Recently, Miller et al. (2019) has shown that levels of As in surface-sediment samples (top $0.5 \mathrm{~cm}$ ) collected from Hambone Lake in 2016 remain well above the Canadian sediment quality guidelines for the protection of aquatic life (As concentration range $=195^{-}$ 622 mg.kg- ${ }^{-1}$. Interim Sediment Quality Level (ISQL) = 5.9 mg.kg- ${ }^{-1}$; Probable Effect

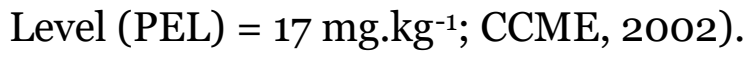




\subsection{Materials \& Methods}

\subsubsection{Sampling design and field methods}

Forty near-surface sediment samples were collected from Frame Lake $(n=25)$ and Hambone Lake $(n=15)$ during the summer field seasons of 2014 and 2016, respectively. Lakes were accessed by a boat and surface-sediment samples were collected using an Ekman Grab sampler. The upper $0.5 \mathrm{~cm}$ of sediment from each Ekman Grab was retained for Arcellinida, sedimentological and geochemical analysis using an inert plastic laboratory spoon. The coordinates for each sampled site within the lakes were recorded using a geographic positioning system (GPS; Supplementary Table 5.1). Water depth was determined for each sampling station using a HONDEX Honda portable handheld depth sounder (model: PS-7). Muddy substrates were preferentially selected for sampling, as nutrient poor silt to sand substrates are generally characterized by allochthonous arcellinidan populations (Patterson and Kumar, 2002).

\subsubsection{Laboratory methods}

\subsubsection{Particle Size Analysis}

Particle size analysis (PSA) was performed on the sediment sub-samples to identify textural influence on the intra-lake distribution of Arcellinida and element concentrations at each station. Following the sample preparation protocols of Murray (2002) and van Hangstum et al. (2007), PSA sub-samples were first digested in a heated bath $\left(70 \mathrm{C}^{\circ}\right.$ ) with $10 \% \mathrm{HCl}$ and $30 \% \mathrm{H}_{2} \mathrm{O}_{2}$ to remove carbonate 
and organic content, respectively. Digested sub-samples were then analyzed for their sedimentary grain size using a Beckman Coulter LS13 320 laser diffraction analyzer fitted with a universal liquid medium (ULM) sample chamber over a measurement range between 0.4 and $2000 \mu$ m. Sub-samples were loaded into the instrument until an obscuration level of $10 \pm 3 \%$ was attained. GRADISTAT (Version 8; Blott and Pye, 2001) was used to compile the results (Supplementary Table 5.1). Garnet15 (mean diameter $15 \mu \mathrm{m}: \pm 2 \mu \mathrm{m}$ ), an accuracy standard supplied by Beckman Coulter, was run once per month, while an in-house mud sample (Cushendun Mud; mean diameter $=20.5 \mu \mathrm{m}: \pm 0.76 \mu \mathrm{m})$ was run at the start of every session as a precision control. Generated mean values for the analyzed Garnet15 $(16.2 \mu \mathrm{m})$ and Cushendun $(21.1 \mu \mathrm{m})$ fell within the standard deviation ranges for optimal instrument performance.

\subsubsection{Geochemical analysis}

Elemental concentrations of the sediment sub-samples were analyzed using ICPMS using the aqua regia digestion protocol (ICP-MS $1 \mathrm{~F} / \mathrm{AQ250}$ package) at Bureau Veritas, Vancouver (Supplementary Table 5.1). Aqua regia digestion was employed instead of a 4-acid digestion protocol, as the former provides the total concentration of metal(loids) that could potentially become bioavailable, while the latter method can potentially volatilize non-bioavailable As (Parsons et al., 2012), which would generate results inappropriate for comparison with Arcellinida data. Analytical precision was assessed using duplicate samples. Calculated Relative Percent Difference (RPD) was less than 5\% for As (RPD range $=0.196 \%-1.379 \%$, 
$n=3)$. Analytical accuracy was assessed using standard reference materials: 1) STD DS10 $(n=3)$; 2) STD D11 $(n=6)$; and, 3) STD OREAS45EA $(n=9)$. Mean As concentration measured in STD DS10 was $44.8 \mathrm{mg} \cdot \mathrm{kg}^{-1} \pm 1.63(n=3)$ compared to an expected concentration of $46.2 \mathrm{mg} \cdot \mathrm{kg}^{-1}($ mean RPD $=3.69 \% \pm 2.704)$. Mean As concentration measured in STD DS11 was $41.9 \mathrm{mg} \cdot \mathrm{kg}^{-1} \pm 4.38(n=6)$ compared to an expected concentration of $42.8 \mathrm{mg} \cdot \mathrm{kg}^{-1}($ mean RPD $=5.62 \% \pm 3.908)$. Mean measured As concentration for STD OREAS45EA was $10.85 \mathrm{mg} \cdot \mathrm{kg}^{-1} \pm 0.751$ $(n=9)$ compared to an expected As concentration of $10.3 \mathrm{mg} \cdot \mathrm{kg}^{-1}$ (mean RPD = $7.23 \% \pm 4.0065)$. Laboratory methods blanks $(n=11)$ resulted in As detection in two blanks (detected As concentrations $=0.2 \mathrm{mg} \cdot \mathrm{kg}^{-1}$ and $0.5 \mathrm{mg} \cdot \mathrm{kg}^{-1}$ ).

\subsubsection{Olsen phosphorus (OP) extraction}

Sediment-based phosphorus was measured to determine the trophic status of the lakes. Phosphorus was examined using the Olsen phosphorus extraction method (Olsen P; Olsen et al., 1954) as it provides a reliable measure of phosphorus that is bio-available for aquatic plants and macro- and micro-algal communities (Zhou et al. 2001).

\subsubsection{Loss-on-ignition}

Loss on Ignition (LOI) analysis was carried out on the 38 sub-samples (insufficient materials for samples FL1 and FL7) to determine the percentage of moisture, organic carbon, carbonate, and minerogenic content (Heiri et al., 2001). Moisture content was determined by comparing measurements before and after samples 
were placed in an oven at $100^{\circ} \mathrm{C}$ for 24 hours. A Thermo Scientific Thermolyne Benchtop Muffle Furnace (model: F48025-60-80) was then programmed for sequential burning at $550^{\circ} \mathrm{C}$ and $900^{\circ} \mathrm{C}$ to determine percentages of organic carbon and carbonate, respectively (Supplementary Table 5.1). Analytical precision was assessed using five duplicate samples. Calculated RPD for moisture, organic carbon, carbonate, and minerogenic content was less than 7.5\% ( $n=38)$. Carbonate content was excluded from ensuing statistical analysis due to the high calculated RPD (RPD range $=9.4-106.3 \%)$.

\subsubsection{Micropaleontological analysis}

Three $\mathrm{cm}^{3}$ of material was sub-sampled from each sample for micropaleontological analysis. These sub-samples were wet sieved through a $297 \mu \mathrm{m}$ mesh to remove any coarse debris and then through a $37 \mu \mathrm{m}$ mesh to separate Arcellinida from the fine particles fraction (Patterson and Kumar, 2002). Sieved sub-samples were then subdivided into six aliquots for quantitative analysis using a wet-splitter (after Scott and Hermelin, 1993). Aliquots were analyzed wet for Arcellinida on a gridded petri dish using an Olympus SZH dissecting binocular microscope (7.5-64X magnification) until a statistically significant number of specimens were quantified (minimum of 150 tests; Patterson and Fishbein, 1989; Supplementary Table 5.1). All sub-samples had statistically significant numbers of Arcellinida tests and were thus included in subsequent statistical analyses.

Identification of Arcellinida primarily followed the illustrations and descriptions found in various key papers where specimens are well illustrated (e.g. 
Reinhardt et al., 1998; Roe et al., 2010; Patterson et al., 2013; Steele et al., 2018) as well as the extensive online databased found in the Microworld database (Siemensma, 2019). Because lacustrine arcellinidan species can display considerable environmentally controlled infraspecific morphological variability (e.g., Medioli and Scott, 1983), the accepted practice has been to designate informal infrasubspecific "strain" names for these ecophenotypes (Asioli et al., 1996; Reinhardt et al., 1998; Patterson and Kumar, 2002). While infrasubspecific level designations have no status under the International Zoological Code of Nomenclature (art. 45.5; 4th edition, 1999; ICZN, 1999), they have been extensively used in the literature for defining environmentally significant populations within lacustrine environments (e.g. Reinhardt et al. 1998; Patterson and Kumar, 2000; Patterson and Kumar, 2002; Roe et al., 2010; Steele et al., 2018). Scanning electron microscope images of common species and strains were obtained using a Tescan Vega-II XMU VP scanning electron microscope (SEM) in the Carleton University Nano Imaging Facility. All SEM plated were digitally produced using Adobe Photoshop ${ }^{\mathrm{TM}}$ CC 2018 (Figure 5.2; Figure 5.3).

\subsubsection{Statistical analysis}

Twenty-five Arcellinida species and strains were identified in 40 near-surface sediment sub-samples (Supplementary Table 5.1). The Probable Error (pe) was calculated for each sub-sample:

$$
\text { pe }=1.96\left(\frac{s}{\sqrt{X i}}\right)
$$




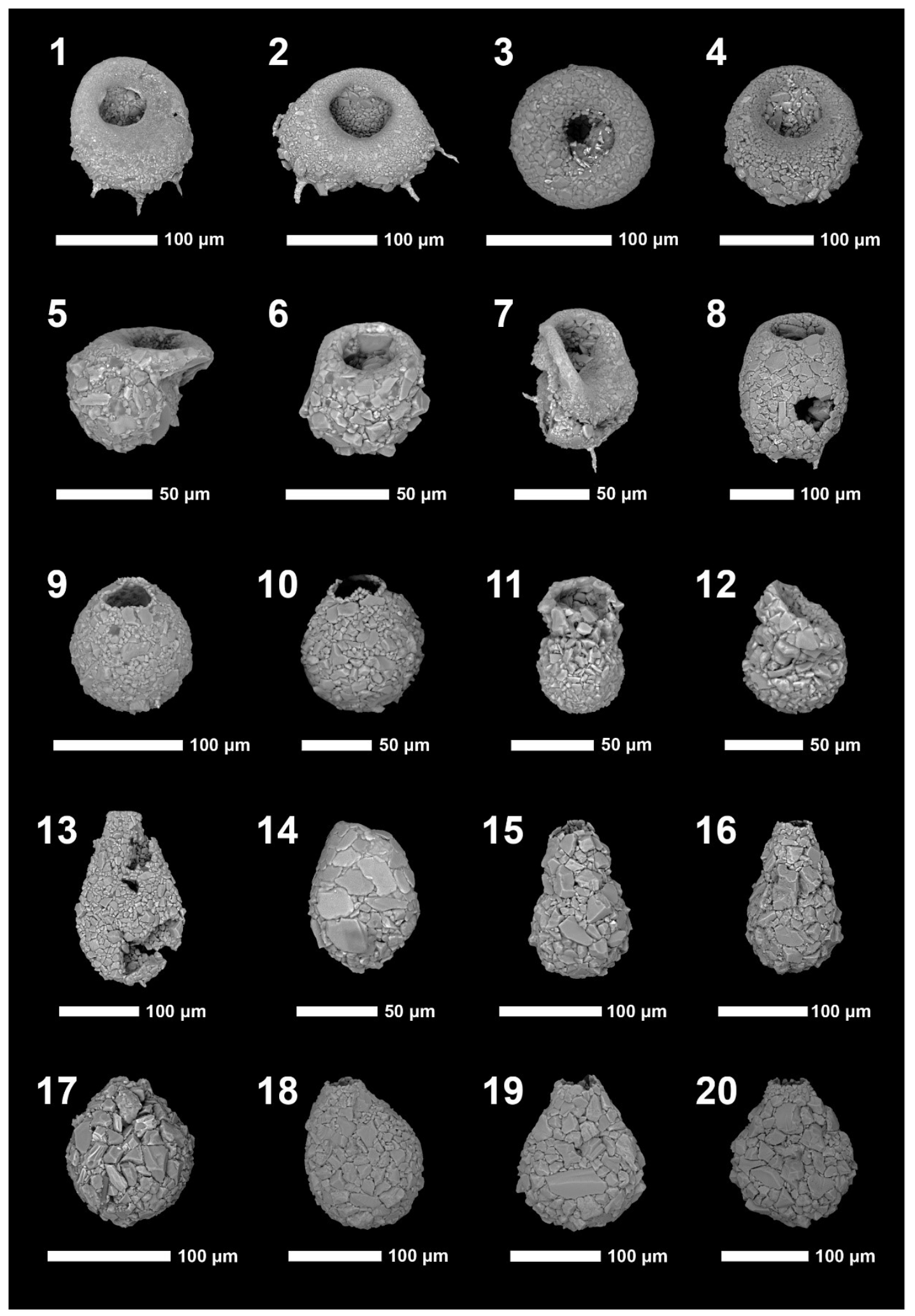


Figure 5. 2: Scanning electron microscope plate of Arcellinida specimens from Frame Lake and Hambone Lake. 1-2 Centropyxis aculeata (Ehrenberg 1832) stain "aculeata". 3-4 Centropyxis aculeata (Ehrenberg 1832) stain "discoides". 5-6 Centropyxis constricta (Ehrenberg 1843) stain "aerophila". 7-8 Centropyxis constricta (Ehrenberg 1843) stain "constricta". 9-10 Cucurbitella tricuspis (Carter 1856). 11-12 Conicocassis pontigulasiformis (Beyens, Chardez, and De Bock, 1986) Nasser and Patterson, 2015. 13 Hyalosphenia papilio Leidy, 1874. 14 Heleopera sphagni (Leidy 1874). 15-16 Lagenodifflugia vas (Leidy 1874). 17-18 Lesquereusia spiralis (Ehrenberg 1840). 19-20 Pontigulasia compressa (Carter 1864). 


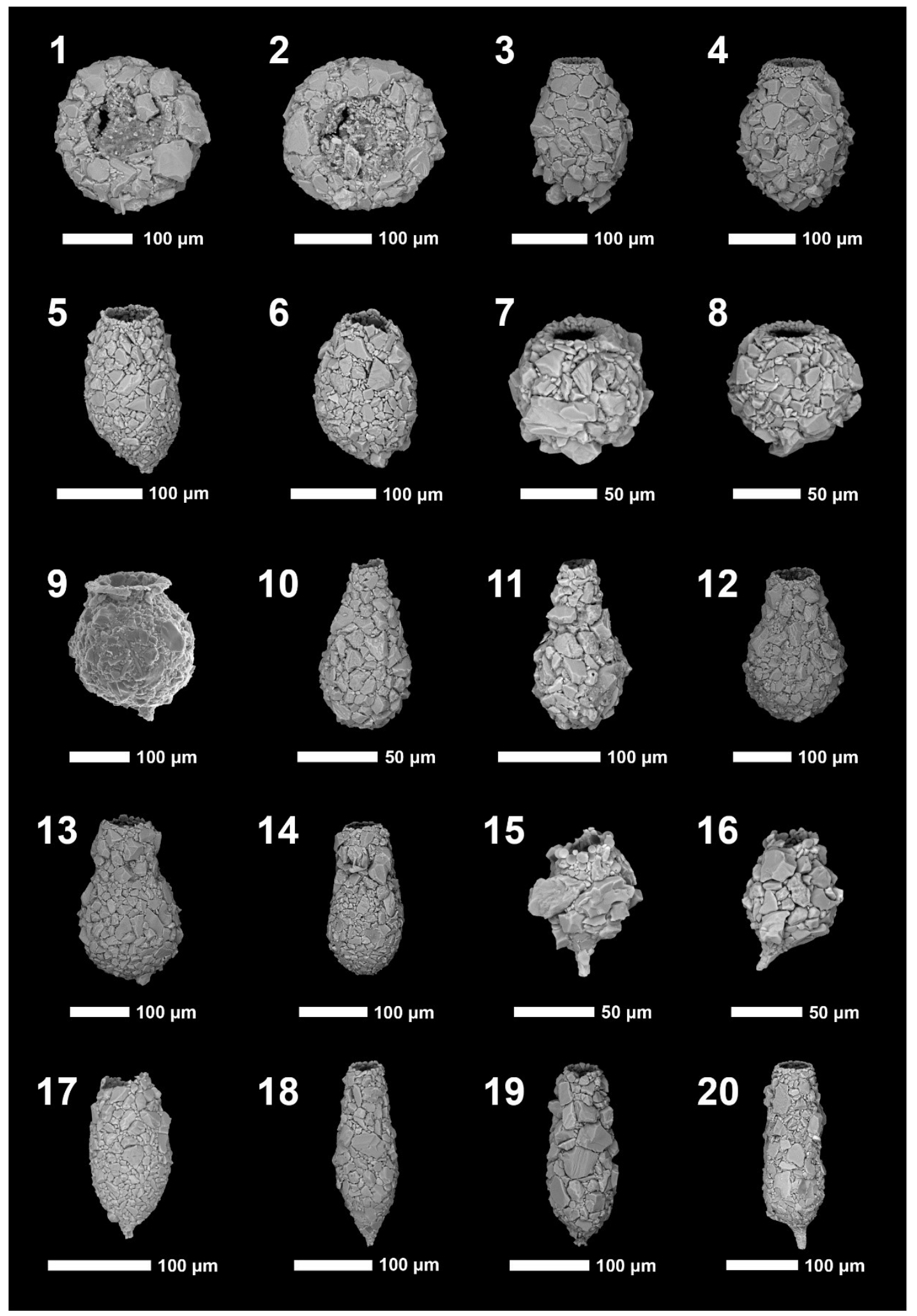


Figure 5. 3: Scanning electron microscope plate of Arcellinida specimens from Frame Lake and Hambone Lake. 1-2 Phryganella nidulus Penard 1902. 3-4 Difflugia glans Penard 1902 strain "glans".5-6 Difflugia glans Penard 1902 strain “distenda”. 7-8 Difflugia globulosa (Dujardin, 1837) Penard, 1902. 9 Difflugia urceolata Carter 1864 strain "urceolata". 10-11 Difflugia oblonga Ehrenberg 1832 strain "oblonga". 12-13 Difflugia oblonga Ehrenberg 1832 strain "tenuis". 14 Difflugia oblonga Ehrenberg, 1832 strain "lanceolata". 15-16 Difflugia elegans Penard 1890. 17-18 Difflugia protaeiformis Lamarck 1816 strain "acuminata". 19 Difflugia protaeiformis Lamarck 1816 strain "claviformis". 20 Difflugia curvicaulis Penard 1899. 
where $\mathrm{S}$ is the standard deviation of the population count and $\mathrm{Xi}$ is the fractional abundance (Patterson and Fishbein, 1989). A sample count was deemed statistically insignificant if the probable error exceeded the total count for a sample. All samples contained statistically significant populations.

Standard error (Sxi) was calculated for each sample using the following equation:

$$
S x i=1.96 \sqrt{\frac{F 1(1-F 1)}{N i}}
$$

where $\mathrm{F} 1$ is the fractional abundance of species and $\mathrm{Ni}$ is the total number of counts. Species were considered to be present in insignificant number if the standard error exceeded the total counts for that species in all sub-samples (Patterson and Fishbein, 1989). All species and strains were found to be present in statistically significant numbers.

The Shannon Diversity Index (SDI; Shannon, 1948) was calculated using the vegan package in RStudio statistical software (version 0.98.1028; R Core Team, 2014) to assess arcellinidan diversity as a measure of ecological health in both lakes. Samples were considered healthy if the SDI was between 2.5 and 3.5, in transition if SDI was between 1.5 and 2.5, and stressed if SDI was below 1.5 (Magurran, 1988; Patterson and Kumar, 2002). The ratio between difflugid and centropyxid species (D/C; Neville et al., 2011) was used in tandem with SDI as a measure of the relative ecological health of the sampled lakes (Supplementary Table 5.1). 


\subsubsection{Data screening, variables selection, and multivariate}

\section{statistics}

Any variables in the arcellinidan relative abundance, LOI, PSA, and ICP-MS data sets having issues associated with more than $25 \%$ of their values (i.e. missing values, below detection or above detection) were removed (Riemann et al., 2008). This screening procedure resulted in the removal of six variables from the ICP-MS data set (Te, Ge, Ta, In, Pd, and Pt). A Principle Component Analysis (PCA; Pearson, 1901; Hotelling, 1933) plot was employed to evaluate redundancies in data and further reduce the number of parameters to be included in constrained ordination.

Q-mode and R-mode cluster analysis was carried out on the 25 arcellinidan species and strains in 40 the screened samples. Q-mode cluster analysis was employed to group samples according to similarities in their faunal composition using Ward's Minimum variance method (Ward, 1963; Fishbein \& Patterson, 1993). R-mode cluster analysis was employed to determine which species and strains $(n=25)$ coexist with each other as well as the dominant taxa responsible for shaping the faunal structure of the identified assemblages. The statistical significance of the identified clusters was calculated using the PVClust package in RStudio. A two-way cluster analysis heatmap was generated using the heatmap.2 function of the gplots package in RStudio (Figure 4). Nonmetric Multidimensional Scaling (NMDS; Kruskal, 1964) was used to further investigate the results of cluster analysis by assessing the similarity between identified assemblages in multidimensional space (Figure 5). 


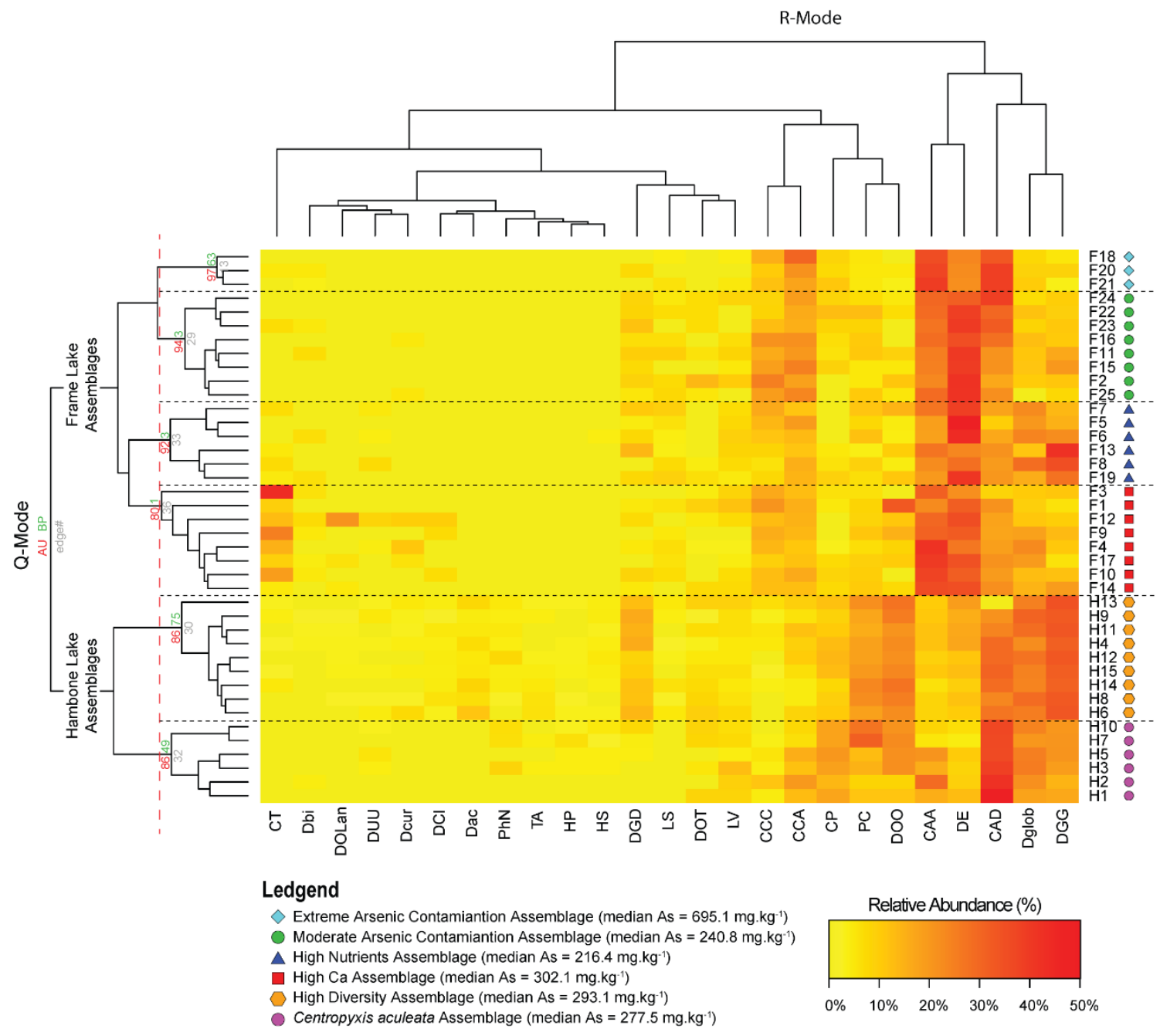

Figure 5. 4: Arcellinida assemblages based on A two-way heatmap cluster analysis. The two-way heat map dendrogram shows the relative abundance of the 25 identified Arcellinida species and strains (R-mode; horizontal dendrogram) in the sample of the identified assemblages (Q-mode; vertical dendrogram). The coloured numbers on the Q-mode dendrogram represents the results of PVClust analysis that shows the statistical significance of the identified assemblages (red numbers). . CCA, Centropyxis aculeata "aculeata".CCD, Centropyxis aculeata "discoides". CCA, Centropyxis constricta "aerophila". CCC, Centropyxis constricta "constricta". CT, Cucurbitella tricuspis. CP, Conicocassis pontigulasiformis. HP, 
Hyalosphenia papilio. HS, Heleopera sphagni. LV Lagenodifflugia vas. LS Lesquereusia spiralis. PC Pontigulasia compressa. PhN, Phryganella nidulus. DGG, Difflugia glans "glans". DGD, Difflugia glans "distenda". Dglob Difflugia globulosa. DUU, Difflugia urceolata "urceolata". DOO, Difflugia oblonga "oblonga". DOT, Difflugia oblonga "tenuis". DOLan, Difflugia oblonga "lanceolata". DE, Difflugia elegans. Dbi, Difflugia bicornis. DA, Difflugia protaeiformis “acuminata". DCl, Difflugia protaeiformis "claviformis". DCur, Difflugia curvicaulis. 


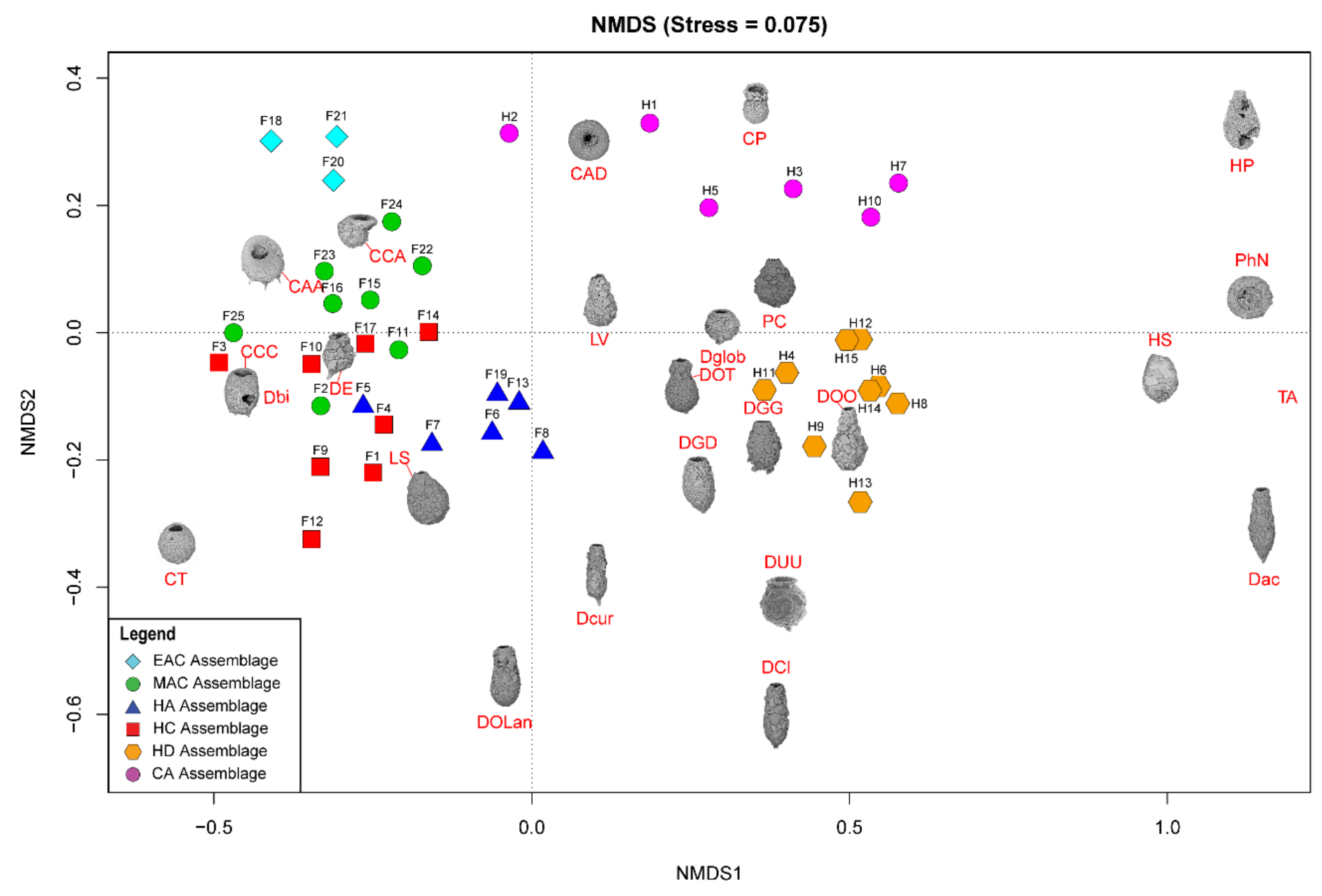


Figure 5. 5: Nonmetric Multidimensional Scaling (NMDS) bi-plot. The coloured symbols represent the samples of the identified assemblages in Frame Lake and Hambone Lake. CCA, Centropyxis aculeata "aculeata".CCD, Centropyxis aculeata “discoides”. CCA, Centropyxis constricta “aerophila”. CCC, Centropyxis constricta “constricta”. CT, Cucurbitella tricuspis. CP, Conicocassis pontigulasiformis. HP, Hyalosphenia papilio. HS, Heleopera sphagni. LV Lagenodifflugia vas. LS Lesquereusia spiralis. PC Pontigulasia compressa. PhN, Phryganella nidulus. DGG, Difflugia glans "glans". DGD, Difflugia glans “distenda". Dglob Difflugia globulosa. DUU, Difflugia urceolata "urceolata". DOO, Difflugia oblonga "oblonga". DOT, Difflugia oblonga "tenuis". DOLan, Difflugia oblonga "lanceolata". DE, Difflugia elegans. Dbi, Difflugia bicornis. DA, Difflugia protaeiformis “acuminata”. DCl, Difflugia protaeiformis "claviformis". DCur, Difflugia curvicaulis. 
Redundancy analysis (RDA; van den Wollenberg, 1977) was used to evaluate the relationship between the identified arcellinidan assemblages and the measured parameters in both lakes (Figure 5.6). A series of partial RDAs (pRDA), coupled with variance partitioning tests, were also carried out to identify the significance of the variance in the arcellinidan distribution that is attributed to the analyzed measured variables. Variables with a $p<0.05$ were considered to be significant contributors to variance in the arcellinidan assemblage. Data sets from Frame Lake (25 samples and 21 species and strains) and Hambone Lake (15 samples and 25 species and strains) were analyzed separately for RDA and pRDA due to the apparent hydroecological differences between both lakes, which may result in masking the impact of different primary controls in each lake.

\section{$5 \cdot 5$ Results}

\subsubsection{Intra-Lake distribution of As}

Sedimentary As concentrations in Frame Lake and Hambone Lake (median As concentration $=283.9 \mathrm{mg} \cdot \mathrm{kg}^{-1} ;$ range $\left.=66.9-1336.6 \mathrm{mg}^{-\mathrm{kg}^{-1}} ; n=40\right)$ are above the Canadian sediment quality guidelines for the protection of aquatic life (ISQL $=5.9$ mg.kg-1 $;$ PEL = 17 mg.kg-1 ; CCME, 2002). Arsenic levels are also notably higher than the Yellowknife area's background concentration (20-30 ppm; Galloway et al., 2015) in all samples. Median As concentrations in Frame Lake (270.8 mg.kg-1; $n=25)$ and Hambone Lake (293.1 mg.kg-1; $n=15)$ are relatively similar, but As concentrations are more variable in Frame Lake (As range $=145.1-1336.6 \mathrm{mg} . \mathrm{kg}^{-}$ 1) compared to Hambone Lake (As range $=66.6-488.3 \mathrm{mg} \cdot \mathrm{kg}^{-1}$ ). 

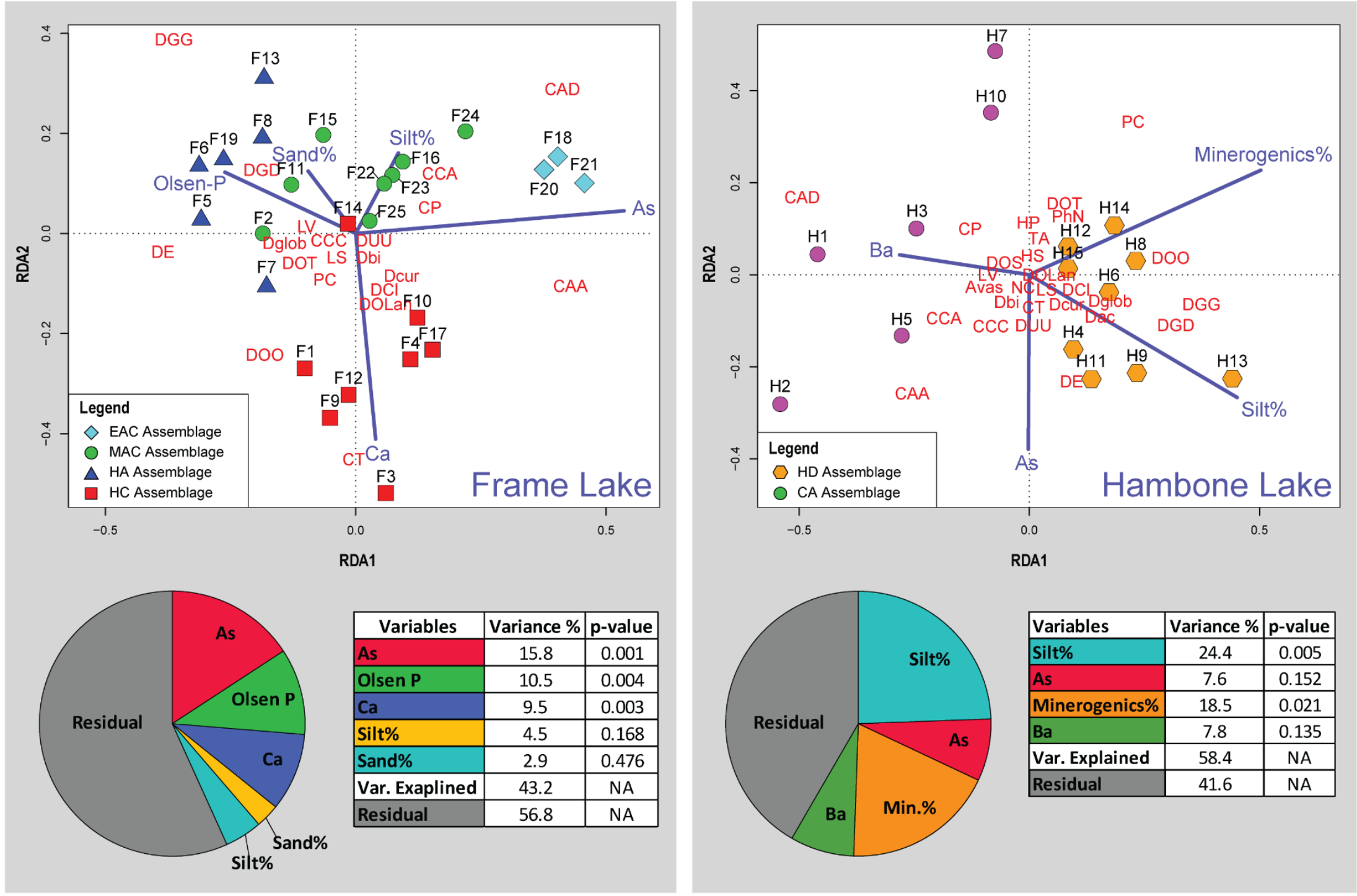
Figure 5. 6: Redundancy analysis (RDA) tri-plots and variance partitioning results. The coloured symbols represent the samples of the identified assemblages in Frame Lake and Hambone Lake. The dark blue lines represent the variables selected in both lakes. CCA, Centropyxis aculeata "aculeata”.CCD, Centropyxis aculeata "discoides”. CCA, Centropyxis constricta "aerophila". CCC, Centropyxis constricta "constricta". CT, Cucurbitella tricuspis. CP, Conicocassis pontigulasiformis. HP, Hyalosphenia papilio. HS, Heleopera sphagni. LV Lagenodifflugia vas. LS Lesquereusia spiralis. PC Pontigulasia compressa. PhN, Phryganella nidulus. DGG, Difflugia glans "glans". DGD, Difflugia glans "distenda”. Dglob Difflugia globulosa. DUU, Difflugia urceolata “urceolata”. DOO, Difflugia oblonga “oblonga”. DOT, Difflugia oblonga "tenuis". DOLan, Difflugia oblonga "lanceolata”. DE, Difflugia elegans. Dbi, Difflugia bicornis. DA, Difflugia protaeiformis “acuminata”. DCl, Difflugia protaeiformis “claviformis”. DCur, Difflugia curvicaulis. 
The highest As concentrations in Frame Lake were recorded in sites within and close to the northern basin (median As concentration $=674.4 \mathrm{mg} \cdot \mathrm{kg}^{-1}$; range $=177.5^{-1336.6} \mathrm{mg} \cdot \mathrm{kg}^{-1} ; n=5$ [F17 to F2o]). The rest of the lake exhibited a patchy As distribution with no clear spatial trend (Figure 5.1B). In Hambone Lake, the highest As concentrations were recorded in sites closer to the lake's outlet at the lake's northeastern margin (median As concentration $=386.6 \mathrm{mg} \cdot \mathrm{kg}^{-1} ; n=4[\mathrm{H} 1$, $\mathrm{H} 2, \mathrm{H} 3$, and H4]; Figure 5.1C). In comparison, As levels in the rest of the lake were slightly lower than those recorded in the vicinity of the outlet, but remain well above the CCEM guidelines (median As concentration $=247.2 \mathrm{mg} \cdot \mathrm{kg}^{-1} ; n=11$ ).

\subsubsection{Description of identified Arcellinida assemblages}

Interpretation of the Q-mode cluster analysis and PVClust results led to the identification of six distinct arcellinidan assemblages, four in Frame Lake (assemblages 1-4) and two in Hambone Lake (assemblages 5 and 6): 1) extreme As contamination assemblage (EAC; approximately unbiased probability value [AU $p$-value $]=97 \% ; n=3) ; 2$ ) moderate As contamination assemblage (MAC; AU $p$-value $=94 \% ; n=8) ; 3)$ high calcium assemblage (HC; AU $p$-value $=80 \% ; n=$ 8); 4) high nutrients assemblage ( $\mathrm{HN}$; AU $p$-value $=92 \% ; n=6) ; 5)$ high diversity assemblage (HD; AU $p$-value $=86 \% ; n=9$ ); and 6) Centropyxis aculeata assemblage (CAA; AU $p$-value $=86 \% ; n=6$; Figure 4). The R-mode cluster dendrogram revealed that the faunal composition of the identified assemblages is mostly impacted by five taxa: 1) Centropyxis aculeata (Ehrenberg, 1832) strain "aculeata"; 2) Difflugia elegans Penard, 1890; 3) Centropyxis aculeata 
(Ehrenberg, 1832) strain “discoides”; 4) Difflugia globulosa (Dujardin, 1837) Penard, 1902; and, 5) Difflugia glans Penard, 1902 strain "glans" (Figure 4). Other species of a lesser, yet notable, influence includes C. constricta (Ehrenberg 1843) strain "aerophile", C. constricta (Ehrenberg 1943) strain "constricta", Difflugia oblonga Ehrenberg, 1932 strain "oblonga" and Cucurbitella tricuspis (Carter, 1856) (Figure 4).

\subsubsection{Extreme As Contamination Assemblage (EAC)}

The extreme As contamination assemblage (EAC; $n=3$ ) was identified in three samples from the northern basin of Frame Lake (Figure 5.1B). The three samples were collected from relatively deep (median water depth $=5.5 \mathrm{~m}$; range: $3.5-6.4$ m), organic-rich (median TOC\% $=53.4 \%$; range: $52.1-59.1 \%$ ) and silt-dominated substrates (median Silt\% $=79 \%$; range: $78-83 \%$ ). Arsenic concentrations in the EAC samples were the highest in Frame Lake (median As $=695.1 \mathrm{mg} \cdot \mathrm{kg}^{-1}$; range: 234.9-1336.6 mg. $\mathrm{kg}^{-1}$ ) and are considerably higher than the proposed CCEM sediment quality guidelines.

The faunal density in EAC samples was also the highest in the lake (median $=600$ tests per $\mathrm{cm}^{3} ;$ range $=110-760$ tests per $\mathrm{cm}^{3}$ ) but the species richness was relatively low (median = 13 species; range: $11-14$ species). The relatively low to moderate diversity of the assemblage was reflected by the measured SDI values (range $=1.6-1.9$ ) and is indicative of stressed to transitional environmental conditions (Magurran, 1988). The faunal assemblage structure of EAC was dominated by $C$. aculeata "discodes" (median relative abundance $\%=33.9 \%$; 
range $=25.6-34.7 \%)$ and $C$. aculeata "aculeata" (median relative abundance $\%=$ $32.1 \%$; range $=29.3-35.5 \%$ ). Elevated numbers of $D$. elegans (median relative abundance $\%=11.5 \%$; range $=11.3-13 \%)$ and $C$. constricta "constricta" (median relative abundance $\%=10.3 \%$; range $=7.1 \%-21.3 \%$ ) were also present in most samples. Healthy-environmental conditions indicators like D. oblonga "oblonga" (median relative abundance $\%=0.26 \%$; range $=0-0.6 \%$ ), D. globulosa $($ median relative abundance $\%=1.82 \%$; range $=1.3-2.3 \%$ ); $C$. tricuspis (median relative abundance $\%=0 \%$; range $=0-0.6 \%$ ), and D. glans "glans" (median relative abundance $\%=0.67 \%$; range $=0.26-1.82 \%$ ) were present in low numbers

Cluster analysis and NMDS showed that EAC samples clustered closely together (Figure 5.4; Figure 5.5). The RDA tri-plot indicated that the EAC samples associating positively with As and, to a lesser extent, silt particle size fraction and negatively with Olsen $\mathrm{P}$ and sand particle size fraction (Figure 5.6).

\subsubsection{High Calcium Assemblage (HC)}

Samples hosting the High Calcium Assemblage $(\mathrm{HC} ; n=8)$ are recognized in the southern section of Frame Lake except for samples F14 and F17, which are from the northern end (Figure 5.1B). Samples of the assemblage were collected from relatively shallow to moderately deep substrates (median water depth $=2 \mathrm{~m}$; range: $1.1-3.2 \mathrm{~m}$ ) that are dominated by the silt particle size fraction (median Silt\% = 79\%; range: $15-82 \%)$ and are characterized by relatively high organic content (median TOC\% = 36\%; range: $20-52.8 \%$ ). Arsenic concentrations in HC samples are still high $\left(\right.$ median $=302.1 \mathrm{mg} \cdot \mathrm{kg}^{-1} ;$ range $\left.=151.1-492.3 \mathrm{mg} \cdot \mathrm{kg}^{-1}\right)$ but are notably 
lower than the levels characterizing the EAC samples. Nevertheless, such levels are well above the ISQL and PEL proposed concentrations.

Samples of HC are characterized by notably lower faunal density compared to the $\mathrm{EAC}$ samples $\left(\right.$ median $=287$ tests per $\mathrm{cm}^{3}$; range $=123-976$ tests per $\mathrm{cm}^{3}$ ). An exception is sample $\mathrm{F}$, which is characterized by the highest faunal diversity in Frame Lake (976 tests per $\mathrm{cm}^{3}$ ). Species richness of $\mathrm{HC}$ is the highest in Frame Lake with a median of 17 species (range: $13-20$ species). The measured SDI values for the samples of the assemblage (1.8-2.3) is reflective of environmental conditions transitioning toward more hospitable conditions (Magurran, 1988). Similar to EAC, the faunal structure of the assemblage is dominated by C. aculeata "aculeata", albeit present in lower numbers (median relative abundance \% = 25.9\%; range $=12-39.9 \%)$. The notable increase in the numbers of $D$. elegans in $\mathrm{HC}$ (median relative abundance $\%=23.5 \%$; range $=11-28.5 \%$ ) resulted in the taxa co-dominating the assemblage along with C. aculeata "aculeata". The numbers of C. aculeata "discodes" (median relative abundance $\%=8.3 \%$; range $=1.6-11.1 \%$ ) and C. constricta "aerophile" (median relative abundance $\%=4.19 \%$; range $=2.8$ 6\%) declined in the samples of HC. In contrast, the proportions of D. oblonga "oblonga" (median relative abundance $\%=2 \%$; range $=0-25.1 \%$ ), D. globulosa (median relative abundance $\%=4.4 \%$; range $=2.1-12.3 \%$ ), $D$. glans "glans" (median relative abundance $\%=2.7 \%$; range $=0.7-8.7 \%$ ), and especially $C$. tricuspis (median relative abundance $\%=4.4 \%$; range $=0.6-43 \%$ ) increased notably in HC.

Cluster analysis and NMDS show a close association between the samples of the HC, with only F3 and F14 plotting more distinctly from the assemblage on 
the NMDS bi-plot (Figure 5.4; Figure 5.5). The results of RDA reveal a strong positive association between the $\mathrm{HC}$ samples and $\mathrm{Ca}$ and a negative association with the particle size analysis parameters, sand and silt fractions (Figure 5.6).

\subsubsection{Moderate As Contamination Assemblage (MAC)}

The Moderate As Contamination Assemblage (MAC; $n=8$ ) was found to inhabit substrates in the northern section of Frame Lake, with two outliers from the southern section of the lake (samples F2 and F11; Figure 5.1B). The MAC samples were collected from relatively shallow substrates (median water depth $=1.05 \mathrm{~m}$; range: $0.7-1.5 \mathrm{~m}$ ) that are organic-rich (median TOC\% $=55.7 \%$; range: $42.3^{-}$ 59.4\%) and are silt-dominated (median Silt $\%=77 \%$; range: $72-81 \%$ ). Arsenic concentrations in MAC samples $\left(\right.$ median $=240.8 \mathrm{mg} \cdot \mathrm{kg}^{-1} ;$ range $=145.1-295.3$ mg.kg-1) are slightly lower than the levels characterizing the HC samples but remain far above the acceptable levels of the CCEM guidelines.

The faunal density of samples hosting the MAC is comparatively higher than that of the $\mathrm{HC}\left(\right.$ median $=364$ tests per $\mathrm{cm}^{3} ;$ range $=81-367$ tests per $\left.\mathrm{cm}^{3}\right)$. Species richness of MAC is low and is relatively similar to that of $\mathrm{EAC}$ ( median = 13 species;

range: 12-16 species). The measured SDI values for the samples of the assemblage (1.7-2.1) are indicative of transitional environmental conditions (Magurran, 1988). Unlike the previous two assemblages, the faunal structure of MAC is dominated by D. elegans (median relative abundance $\%=36.1 \%$; range $=22.9-40.1 \%$ ). Elevated numbers of $C$. aculeata "aculeata" (median relative abundance $\%=17.9 \%$; range $=$ 12.5-20.6\%) are high but experienced further decline compared to the numbers in 
EAC and HC. The numbers of other centropyxiid taxa like C. aculeata "discodes" (median relative abundance $\%=14.6 \%$; range $=6.5-34.6 \%), C$. constricta "aerophile" (median relative abundance $\%=8.8 \%$; range $=5 \cdot 3-14.2 \%$ ), and $C$. constricta "constricta" (median relative abundance $\%=7 \%$; range $=1.6-14.3 \%$ ) are higher than those seen in the HC samples. Stress-sensitive taxa like D. oblonga "oblonga" (median relative abundance $\%=0.6 \%$; range $=0-2.9 \%$ ), D. globulosa ( median relative abundance $\%=2.7 \%$; range $=0-3.6 \%$ ), D. glans "glans" (median relative abundance $\%=2.6 \%$; range: $1.3-2.9 \%$ ), and $C$. tricuspis (median relative abundance $\%=0 \%$; range $=0-1.1 \%$ ) were present but in low numbers.

The cluster analysis dendrogram and NMDS bi-plot shows the MAC samples grouping together (Figure 5.4; Figure 5.5). In addition, the NMDS bi-plot shows a notable overlap between MAC and HC samples (Figure 5.5). RDA plot shows a positive association between the MAC and Olsen P, sand particle size fraction, and silt particle size fraction and a negative association with $\mathrm{Ca}$ (Figure $5 \cdot 6)$.

\subsubsection{High Nutrients Assemblage (HN)}

Samples composing the High Nutrients Assemblage (HN; $n=6)$ are mostly found on substrates in the southwestern section of the lake except for samples F2 and F11, which are from the northern section of the lake (Figure 5.1B). Samples were collected from relatively shallow water substrates (median water depth $=1.1 \mathrm{~m}$; range: $01-4.6 \mathrm{~m}$ ) that are characterized by high organic content (median $\mathrm{TOC} \%=$ 43.5\%; range: $16.8-61.3 \%$ ) and silty sediments (median Silt\% $=78 \%$; range: $70-$ 86\%). While the As concentrations characterizing the $\mathrm{HN}$ samples are higher than 
the CCEM guidelines, they are the lowest in Frame Lake with a median of 216.4 $\mathrm{mg} \cdot \mathrm{kg}^{-1}\left(\right.$ range $\left.=168.8-346 \mathrm{mg} \cdot \mathrm{kg}^{-1}\right)$.

The faunal abundance in samples hosting the $\mathrm{HN}$ was the second highest in Frame Lake $\left(\right.$ median $=488$ tests per $\mathrm{cm}^{3}$; range $=380-634$ tests per $\left.\mathrm{cm}^{3}\right)$. The species richness of the assemblage was moderate with a median of 15 species and a range between 12 and 17 species. The measured SDI values for the HN samples $\left(1.5^{-2}\right)$ are reflective of stressed to transitional environmental conditions (Magurran, 1988). However, sample F5 was the only sample with a relatively low SDI value in $\mathrm{HN}$ (1.5). Therefore, the assemblage is more indicative of transitional conditions when F5 is excluded (1.8-2). The dominance of D. elegans continued in this assemblage (median relative abundance $\%=37 \%$; range $=12.9-57 \cdot 3 \%$ ). The assemblage was also characterized by lower numbers of C. aculeata "aculeata" (median relative abundance $\%=10.4 \%$; range $=7.6-17 \%$ ), . . aculeata "discoides" (median relative abundance $\%=8 \%$; range $=2.2-10.4 \%$ ), . constricta "aerophile" (median relative abundance $\%=4.4 \%$; range $=3.1-8.8 \%$ ), and C. constricta constricta (median relative abundance $\%=2.2 \%$; range $=0.7-6.3 \%$ ). While some stress-sensitive taxa like D. oblonga "oblonga" (median relative abundance $\%=$ $1.3 \%$; range $=0.3-4.7 \%$ ) and $C$. tricuspis (median relative abundance $\%=0.56 \%$; range $=0-1.1 \%)$ showed a minor increase in abundance, the numbers of other healthy-conditions indicators like D. globulosa (median relative abundance \% $=10.7 \%$; range $=3.1-18.6 \%)$, D.glans "glans" (median relative abundance $\%=$ 14.5\%; range: 4.2-41.6\%) increased drastically in the samples of $\mathrm{HN}$. 
Results of the cluster analysis and NMDS revealed a close association between the HN samples (Figure 5.4; Figure 5.5). The RDA tri-plot showed a positive association between the $\mathrm{HN}$ and Olsen $\mathrm{P}$ and a negative association with As (Figure 6A).

\subsubsection{High Diversity Assemblage (HD)}

The High Diversity Assemblage (HD; $n=9$ ) was identified in nine samples located in and around the western basin of Hambone Lake (Figure 5.1C). These samples were collected from relatively shallow (median water depth $=1.5 \mathrm{~m}$; range: $0.9-$ $1.9 \mathrm{~m}$ ), organic-rich (median TOC\% $=26.6 \%$; range: $12.7-31.9 \%$ ) substrates that are silt-dominated (median Silt\% $=87.5 \%$; range: 85.7-89.9\%). Arsenic concentrations in HD samples are higher than the CCEM guidelines (median = $293.1 \mathrm{mg} \cdot \mathrm{kg}^{-1} ;$ range $\left.=91.7-488.3 \mathrm{mg} \cdot \mathrm{kg}^{-1}\right)$.

The assemblage was characterized by the highest faunal density (median = 1386 tests per $\mathrm{cm}^{3}$; range $=956-2632$ tests per $\mathrm{cm}^{3}$ ) and species richness (median = 20 species; range: $20-26$ species) in both lakes. The measured SDI values for the samples of the assemblage (2.1-2.3) are reflective of environments transitioning to more hospitable conditions (Magurran, 1988). The faunal structure of the assemblage was dominated by D.glans "glans" (median relative abundance \% = 24.9\%; range: $22.2-27.5 \%)$. The assemblage was also characterized by elevated numbers of $C$. aculeata "discoides" (median relative abundance $\%=16.5 \%$; range $=0-21.8 \%$ ), D. globulosa (median relative abundance $\%=15.1 \%$; range $=11.4-$ 21.6\%), D. oblonga "oblonga" (median relative abundance $\%=12.9 \%$; range $=9.9-$ 
17.6\%), and Potigulasia compressa Dujardinm 1837 (median relative abundance $\%=7.7 \%$; range $=5.8-12.8 \%)$. Other species like D. glans Penard, 1902 strain "distenda" (median relative abundance $\%=3.7 \%$; range $=1.7-6.2 \%$ ), C. aculeata "aculeata" (median relative abundance $\%=2.3 \%$; range $=0.9-3.2 \%$ ), Conicocassis pontigulasiformis (Beyens, Chardez, and De Bock, 1986) Nasser and Patterson, 2015 (median relative abundance $\%=2.5 \%$; range $=1.4-4.6 \%$ ), and $C$. constricta "aerophila" (median relative abundance $\%=1.7 \%$; range $=0.4-3.4 \%$ ) are present in low proportions.

Cluster analysis and NMDS results show the samples of HD clustering closely and distinctly from the assemblages identified in Frame Lake (Figure 4; Figure 5). The results of RDA revealed a positive association between the HD samples and loss-on-ignition-determined minerogenic content and the silt particle size fraction and a negative association with barium (Ba; Figure 5.6).

\subsubsection{Centropyxis aculeata Assemblage (CA)}

Samples hosting the Centropyxis aculeata Assemblage $(\mathrm{CA} ; n=6)$ were found in the southward part of the western basin (H10) and in the eastern arm of Hambone Lake (H1, H2, H3, H5, H7; Figure 5.1B). Samples were collected from relatively shallow (median water depth $=1 \mathrm{~m}$; range: $0.9-1.7 \mathrm{~m}$ ), organic-rich (median TOC $\%=37.7 \%$; range: $11.3-52.1 \%$ ), and silt-dominated substrates (median Silt\% $=85.2 \%$; range: $83-87.5 \%)$. Arsenic concentrations of the CA samples (median $=$ $277.5 \mathrm{mg} . \mathrm{kg}^{-1}$; range $=66.9-422.8 \mathrm{mg} \cdot \mathrm{kg}^{-1}$ ) were slightly lower than those of HD, but were still considerably above the safe levels outlined in the CCEM guidelines. 
The faunal density of the assemblage was lower than that of HD (median = 583 tests per $\mathrm{cm}^{3}$; range $=458-2936$ tests per $\mathrm{cm}^{3}$ ) except for two samples with exceptionally high faunal density $\left(\mathrm{H}_{7}=2936\right.$ tests per $\mathrm{cm}^{3}$ and $\mathrm{H} 1 \mathrm{O}=1150$ test per $\mathrm{cm}^{3}$ ). The species richness of the CA was notably lower than that of HD with a median of 16 species and a range between 12 to 17 species. The measured SDI values for the samples of the assemblage (1.7-2.1) are reflective of transitional environmental conditions (Magurran, 1988). Unlike the HD, the faunal structure of the CA assemblage was dominated by $C$. aculeata "discoides" (median relative abundance $\%=32.7 \%$; range $=29.3-55.5 \%)$. Elevated numbers of D. globulosa (median relative abundance $\%=12.4 \%$; range $=7.4-15.4 \%$ ) and $D$. oblonga "oblonga" (median relative abundance $\%=10.5 \%$; range $=1.6-11.9 \%$ ) were present but were slightly lower than the numbers characterizing the HD samples. Other species like D. glans "glans" (median relative abundance $\%=8.9 \%$; range $=4.7-$ 9.8\%), C. pontigulasiformis (median relative abundance $\%=7.3 \%$; range $=4.3^{-}$ 9.3\%), and C. aculeata "aculeata" (median relative abundance $\%=5.7 \%$; range $=$ 0.7-19.4\%) were present in notable numbers. Species and strains like C. constricta "aerophile" (median relative abundance $\%=3.7 \%$; range $=1-3.2 \%$ ), $P$. compress $a$ (median relative abundance $\%=4.5 \%$; range $=1.6-22.8 \%$ ) were present in low numbers, with the exception of notably high numbers of $P$. compressa in samples $\mathrm{H} 7$ and H10.

The results of the cluster analysis and NMDS show that the samples characterizing the CA cluster closely (Figure 5.4; Figure 5.5). The results of RDA revealed a positive association between the $\mathrm{CA}$ samples and $\mathrm{Ba}$ and a negative 
association with the LOI-determined minerogenic content and silt particle size fraction (Figure 5.6).

\subsection{Discussion}

\subsubsection{Controls over the Intra-lake Arcellinida distribution}

Results of the cluster analysis led to identification of distinct arcellinidan assemblages in Frame Lake $(n=4)$ and Hambone Lake $(n=2)$. The unique faunal structure of these assemblages coupled with the lack of overlap between samples from each lake in the statistical results is reflective of varying intralake hydroecological conditions. The RDA and variance partitioning results support this assessment by showing different sets of variables driving the arcellinidan distribution within both Frame Lake and Hambone Lake (Figure 5.6). While As is indeed identified as a common driver of faunal distribution in both lakes, the statistical results suggest that As may be the dominant overarching driver of assemblage structure in Frame Lake, while having a more subtle impact on the arcellinidan populations in Hambone Lake (Figure 5.6). Nonetheless, our results confirm the impact of As on the intra-lake arcellinidan distribution in both lakes, albeit at different magnitudes, that will be discussed below in the context of the identified assemblages. 


\subsubsection{Frame Lake}

Of the controls on arcellinidan distribution identified in Frame Lake, Ca (9.5\%; $p$ value < 0.004$)$, Olsen P (10.5\%; $p$-value < 0.005$)$, and especially As (15.8\%; $p$ value $<0.003)$ contributed the most toward explaining the variance in the arcellinidan distribution. The observation that As is the most significant control in Frame Lake is not surprising given the results of previous studies that have identified the impact of As contamination on the lake's ecology and sediment quality (Drizawsky and Wilson, 2013, 2016; Gavel et al., 2018; Menard et al., 2019). The SDI values for the identified assemblages (SDI range $=1.5-2.3 ; n=25$ ) are typical of transitional lacustrine environments (Magurran, 1988; Patterson and Kumar, 2002). However, the faunal diversity of some assemblages reflects a transition either toward stressed (e.g. EAC; SDI range $=1.6-1.7$ ) or relatively more hospitable conditions (e.g. HC; SDI range $=1.8-2.3$ ). Samples with elevated As concentrations were associated with lower faunal diversity and higher proportions of stress-tolerant Arcellinida taxa. Such trends are particularly well illustrated in samples of EAC from the north basin, where As concentrations are the highest in Frame Lake (As concentrations range $=674.4-1336.6 \mathrm{mg} \cdot \mathrm{kg}^{-1}$ ). The faunal structure of the low diversity EAC is dominated by Centropyxis species and strains $(\mathrm{D} / \mathrm{C}$ range $=0.18-0.24)$, which is expected given the ability of the opportunistic centropyxids to withstand varying level of environmental stress including that caused by As contamination (Patterson et al., 1996; Reinhardt et al., 1998; Nasser et al., 2016; Gavel et al., 2018). Similar trends are observed in the samples of HC and MAC. However, a notable reduction in As concentrations in these samples (As 
concentrations range $=145.1-492.3 \mathrm{mg} \cdot \mathrm{kg}^{-1} ; n=16$ ), compared to levels observed in the EAC samples, led to a major decline in the number of stress-tolerant taxa and a concurrent increase in faunal diversity and number of more sensitive fauna (e.g. difflugiids; $\mathrm{D} / \mathrm{C}$ range $=0.4-1.6$ ). The increase in the abundance of healthy conditions-indicating species and strains is most evident in the samples of $\mathrm{HN}$ (D/C range $=1.7-3.4)$ and is partly associated with the notable reduction in As concentration at these stations, which are the lowest across the lake (median As concentration $\left.=216.4 \mathrm{mg} \cdot \mathrm{kg}^{-1}\right)$.

While the development of the arcellinidan assemblages in Frame Lake reflect the impact of As contamination, the faunal response to As contamination in assemblages from the southern part of the lake appears to be obscured by the influence of variables pertaining to nutrient loading (i.e. Olsen $\mathrm{P}, \mathrm{Ca}$; total faunal variance explained, $10.5 \%$ and $9.5 \%$, respectively). This assessment is confirmed by the RDA results that show $\mathrm{HC}$ and $\mathrm{HN}$ correlating strongly with $\mathrm{Ca}$ and Olsen P, and weakly with As. Such results suggest that the faunal structure of these assemblages was likely shaped via the combined influence of these three environmental controls rather than As alone. Concentrations of Olsen $\mathrm{P}$ are generally low in Frame Lake (median Olsen P concentrations $=$ of $44 \mathrm{mg} \cdot \mathrm{kg}^{-1} ; n=$ 25) and are highest in samples from the southern part of the lake (median Olsen P range $=49.5^{-60} \mathrm{mg} \cdot \mathrm{kg}^{-1} ; n=14 ;$ Supplementary Table 5.1). Elevated levels of Olsen $\mathrm{P}$ in and around the southern basin may be attributed to inputs from nearby residential and private facilities as well as municipal storm water drainage outflow (Gavel et al., 2018; Menard et al., 2019). Olsen P is a good indicator of bioavailable phosphorus in soils and lakes, with higher concentrations indicating nutrient rich, 
productive, and eutrophic conditions (Zhou et al., 2001). A few studies have demonstrated the significance of Olsen P on the distribution of Arcellinida and the association of higher number of healthy conditions-indicators (e.g. difflugiids and C. tricuspis) with elevated Olsen P concentrations (Roe et al., 2010; Patterson et al., 2012). Interestingly, the highest Olsen $P$ levels in our study were associated with a drastic increase in the numbers of D. elegans in HC and HN (Supplementary Table 5.1). Elevated proportions of $D$. elegans has previously been linked to substrates contaminated by As in the Yellowknife area (Nasser et al., 2016) and elsewhere (Reinhardt et al., 1998; identified as Difflugia protaeiformis strain "amphoralis"). However, the increase in the proportions of D. elegans in this study was associated with a trend of declining As concentrations (Supplementary Table 5.1). Patterson and Kumar (2000) have also linked the abundance of D. elegans (also identified as $D$. protaeiformis "amphoralis") with the availability of their preferred food source, pennate diatoms. The abundance and distribution of diatoms has been shown to be impacted by the availability of phosphorus, which is a limiting nutrient that controls the productivity of plants as well as macro-and micro-algal communities in freshwater systems (e.g. Bostrom et al., 1988; Anneville et al., 2005; Berthon et al., 2014; Brembu et al., 2017). While diatoms were not identified and quantified in this study, the notable increase in D. elegans numbers may reflect a similar increase in the proportions of pennate diatoms, which is in turn possibly attributed to the relatively higher bioavailability of P (i.e. higher Olsen P) concentrations in the southern part of Frame Lake.

As observed with the Olsen $\mathrm{P}$ concentrations, the highest measured $\mathrm{Ca}$ values are exclusive to the southern part of Frame Lake, specifically in the samples 
hosting HC (Supplementary Table 5.1). The RDA plot reveals a close association between $\mathrm{HC}$ samples, Ca, and C. tricuspis along the second RDA axis (Figure 5.6). This association is expected as samples of HC are characterized by the highest concentrations of $\mathrm{Ca}$ along with the highest numbers of $C$. tricuspis. The abundance of $C$. tricuspis has been linked with organic rich substrates and eutrophic conditions (Collins et al., 1990; Patterson et al., 2013). Several studies have suggested a link between elevated Ca concentrations and enhanced lake productivity (Otsuki and Wetzel, 1974; Kelts and Ksü, 1978; Behbehani et al., 1986). Therefore, the increase in C. tricuspis coupled and with a general increase in the faunal diversity and numbers of healthy lake-indicating taxa in HC may be indicative of enhanced lake productivity in the southern part of the lake.

\subsubsection{Hambone Lake}

The silt particle size fraction (variance explained $=24.4 \% ; p$-value $=0.005$ ) and minerogenic content (variance explained $=18.5 \% ; p$-value $=0.021$ ) were identified as the most significant drivers of arcellinidan distribution in Hambone Lake (Figure 5.6). Arcellinida populations and their distribution have been shown to be sensitive to changes in the sedimentary composition of lacustrine substrates, with silt- to mud-dominated substrates often hosting faunally diverse and dense arcellinidan assemblages, while sand-dominated substrates are characterized by allochthonous and stress-indicating assemblages (Roe and Patterson, 2006; Steele et al., 2018). The sedimentary composition of the Hambone Lake assemblages differed in that CA samples have slightly higher sand concentrations and notably 
lower minerogenic content $($ median sand $\%=7.3 \%$; median minerogenic $\%=61 \%$; $n=6$ ) compared to the HD samples (median sand $\%=3.1 \%$; median minerogenic\% $=72.4 \% ; n=9 ;$ Supplementary Table 5.1). These differences are supported by the RDA plot that reveal a close correlation between the samples of HD, silt particle size fraction, and minerogenic content, and a negative association between these variables and CA samples along the first RDA axis (Figure 5.6). While such results may provide an explanation for the relatively higher faunal diversity in the HD samples, it is difficult to fully attribute the relative decline in Arcellinida diversity and species richness and density in CA samples to the meager increase in the sand particle size fraction, or loss of minerogenic content, especially when the sedimentary composition of samples hosting both assemblages are silt-dominated (HD median silt $\%=87.5 \% ; n=9 ;$ CA median silt $\%=85.2 \% ; n=6)$.

The RDA results show As plotting along the second RDA axis, indicating a lower influence of As over the distribution of Arcellinida population in Hambone Lake (Figure 6). These results are surprising given the well documented impact of As contamination on the lake's sediment and water quality (e.g. INAC, 2005; SENES Consultants, 2006; Lorax Environmental, 2007; Reid, 2012; Gibson and Reid, 2014; Miller et al., 2019). However, the measured As concentrations were higher in sites close to the lake's outlet in the northeastern end (median As concentration $=386.6 \mathrm{mg}^{\mathrm{kg}}{ }^{-1} ; n=4[\mathrm{H} 1, \mathrm{H} 2, \mathrm{H} 3$, and H4]; Figure 5.1C). Miller et al. (2019) have identified even higher As concentrations in two sites near the outlet and away from the treated tailings effluents discharge location on the western end $\left(\right.$ HAM-1 As concentration $=622 \mathrm{mg} \cdot \mathrm{kg}^{-1} ;$ HAM-2 As concentration $\left.=576 \mathrm{mg} \cdot \mathrm{kg}^{-1}\right)$. The authors study has also identified authigenic sulfides as the primary As solid 
phase in the lake, and interpreted its predominance as a sign of a continuous downstream post-deposition mobilization of As. Interestingly, the identified arcellinidan assemblages exhibited a subtle, yet notable, response to this downstream migration of As. Samples of CA near the lake's outlet were associated with notably higher abundances of stress-indicating Arcellinida taxa, lower numbers of stress-sensitive taxa $(\mathrm{D} / \mathrm{C}$ range $=0.2-1.1)$, lower faunal diversity (SDI range $=1.6-2.1)$, and lower species richness (median species richness $=16$ species; range $=12-17$ species) and species density (median species density $=583$ tests per $\mathrm{cm}^{3}$ ) compared to samples of HD (Supplementary Table 5.1). These results suggest that As, while identified as a weak control in Hambone, may still be impacting the intra-lake Arcellinida distribution in the lake.

\subsubsection{Consistency of the arcellinidan response to As contamination}

A secondary objective of this study was to determine whether exposure to As derived from the Giant and Tundra mines, but in different minerogenic form, would trigger a similar or different arcellinidan response in Frame Lake and Hambone Lake. The limited, yet growing, body of research on the effects of As contamination on the spatio-temporal distribution of Arcellinida has consistently recognized a significant faunal shift from healthy to stressed assemblages in response to increasing As concentrations (Patterson et al., 1996; Reinhardt et al., 1998; Nasser et al., 2016; Gavel et al., 2018). While the same faunal shift in response to As was observed in both the Frame Lake and Hambone Lake 
assemblages, it was pronounced in the former and more subtle in the latter. This disparity in the faunal response to As is in line with the RDA and variance partitioning results, which indicate a strong As control over the intra-lake distribution of Arcellinida in Frame Lake and a much weaker influence in Hambone Lake (Figure 5.6). With the exception of a few very high As measurements in Frame Lake's northern basin, As concentration in both Lakes were similar (Frame Lake median As $=270.8 \mathrm{mg} \cdot \mathrm{kg}^{-1} ; n=25$; Hambone Lake median As $=293.1 \mathrm{mg} \cdot \mathrm{kg}^{-1} ; n=15$ ). Such similarity, therefor, eliminates variance in As concentration as a possible explanation to this difference in the influence of As control over the arcellinidan distribution in each lake. A likely explanation, given the history of Giant and Tundra mines, is that Arcellinida species and strains in each lake may be responding to As that is derived from a different mineral source.

The mining practices at the former Giant and Tundra mines introduced different forms of As mineralization to area lakes and other environments in their surrounding (Galloway et al., 2017; Schuh et al., 2017; Miller et al., 2019). The use of roasting at the Giant Mine site to liberate gold from the hosting arsenopyrite led to the release of massive amounts of $\mathrm{As}_{2} \mathrm{O}_{3}$ to the atmosphere (20,000 tonnes before 1963; Wyre, 2009), which eventually accumulated in the sediments of many lakes around the mine. Gold at the Tundra Mine was associated with As-bearing sulfides, mainly arsenopyrite from hydrothermal mineralization, and was predominantly separated using the free-milling process (Ransom and Robb, 1986). Disposal and weathering of mine tailings, seepage from nearby tailings 
containment ponds, and discharge of treated tailings effluent have been identified as the primary pathways of As into lakes around the Tundra Mine site (Reid et al., 2012; Miller et al., 2019). Compared to naturally occurring As sulphides (e.g. arsenopyrite), roaster-derived $\mathrm{As}_{2} \mathrm{O}_{3}$ is more soluble, bioavailable, and bioaccessible (Plumlee and Mason, 2011). The dissolution of sediment bound $\mathrm{As}_{2} \mathrm{O}_{3}$ often results in the release of toxic species of $\mathrm{As}\left(\mathrm{As}^{3+}\right.$ and $\left.\mathrm{As}^{+}\right)$into sediment porewater. When porewater conditions are reductive, these As species will then diffuse toward the overlaying surface water and as a result of hydrologic redox conditions in the lake bottom sediments often increase in concentrations near the sediment-water interface, thus elevating the risk of As exposure for arcellinidan communities living there.

While we were unable to confirm whether $\mathrm{As}_{2} \mathrm{O}_{3}$ is the dominant As host in Frame Lake, due to the complicated protocols required to identify As species in lake sediments (e.g., Galloway et al., 2017), it is reasonable to assume that the elevated As concentrations in the lake are of an anthropogenic origin and are particularly derived from the diagenesis of $\mathrm{As}_{2} \mathrm{O}_{3}$. This assessment is supported by the results of studies in the Yellowknife area, NT that have demonstrated the persistence of $\mathrm{As}_{2} \mathrm{O}_{3}$ in lake sediments (Galloway et al., 2017; Schuh et al., 2018). Additionally, Van Der Berge et al. (2017) have recently identified soluble $\mathrm{As}_{2} \mathrm{O}_{3}$ particles to be the primary source of As in sediment porewater in three lakes near the City of Yellowknife. Therefore, the pronounced response of the Frame Lake assemblages, along with statistical significance of As control, may be attributed to prolonged arcellinidan exposure to As contamination due to the continuous supply of As from dissolving solid phase $\mathrm{As}_{2} \mathrm{O}_{3}$. In contrast, the weaker Arcellinidan 
response to As and the insignificant As control in Hambone Lake is likely more reflective of the dominance of a different As mineral form in the lake sediments. Interestingly, Miller et al. (2019) have identified authigenic As-bearing sulphides as the primary host of As in near-surface sediments of Hambone Lake. The low solubility of As sulphides, compared to $\mathrm{As}_{2} \mathrm{O}_{3}$, renders them less bioavailable and bioaccessible (Plumlee and Mormon, 2011). This reduced As bioavailability may have resulted in a less frequent release of As into porewaters, which in turn triggered the notably weak faunal response in Hambone Lake.

Research focusing on characterizing the nature and type of the dominant As species and mineral forms in impacted lakes in the central NT is ongoing. However, the progress of this line of research is currently slowed down by the elevated cost of sample analysis and complicated nature of speciation protocols. Because of these limitations, As speciation analysis is only conduced once preliminary geochemical analysis (e.g., ICP-MS) is conducted to evaluate the level of As contamination and the possibility of post-depositional mobility of As. The results of this study provide new insight into the value of using Arcellinida not only for monitoring As contamination but also the potential of using the group as reconnaissance tool to further guide As speciation efforts by identifying impacted lakes where As is likely to be mobile and bioavailable due to the nature of the source As mineralization. 


\subsection{Conclusions}

This research quantified the intra-lake relationship between Arcellinida fauna and variability of As derived from two former gold mines, and other lake environmental variables through analysis of 40 sediment-water interface samples from Frame Lake $(n=25)$ in the Yellowknife area, and Hambone Lake in the Courageous Lake region $(n=15)$.

Cluster analysis, supported by PVClust, and NMDS were used to identify distinct Arcellinida species assemblages in each lake, while RDA was employed to quantify the relationship between the identified groups and geochemical, sedimentary, and organic controls. Interpretation of cluster analysis and NMDS results led to the identification of distinct arcellinidan assemblages in Frame Lake $(n=4)$ and Hambone Lake $(n=2)$ that reflect hydroecological conditions unique to each lake. Results of the RDA revealed a total of seven variables that controlled the arcellinidan distribution in Frame Lake (As, Olsen P, Ca, and Silt and Sand particle size fractions; total variance explained $=43.2 \%$ ) and Hambone Lake (Silt particle size fraction, LOI-determined minerogenic content, Ba, and As; total variance explained $=58.4 \%$ ). Arsenic was found to be the most statistically significant control in Frame Lake (total variance explained $=15.8 \% ; p$-value $=$ o.001). Stress-indicating assemblages (e.g. EAC and MAC; ) were associated with elevated As levels, while stress-sensitive Arcellinida species and strains thrived in healthier assemblages (e.g. HC and HM; SDI range $=1.8-2.3$ ) that were linked to low As concentrations and a higher influence of nutrient loading controls like Olsen $\mathrm{P}(10.5 \% ; p$-value $=0.004)$ and $\mathrm{Ca}(9.5 \% ; p$-value $=0.003)$. In contrast, the 
impact of As on Arcellinida distribution was less statistically significant in Hambone Lake $(7.6 \% ; p$-value $=0.152)$, with variables such as silt particle size fraction $(24.4 \% ; p$-value $=0.005)$ and minerogenic content $(18.5 \% ; p$-value $=$ o.021) explaining a more significant portion of the total faunal variance. However, a major increase in the proportion of stress-indicting Arcellinida taxa near the lake's outlet, away from the treated tailings effluents discharge location at the western shore, is consistent with recently recognized spatial patterns attributed to the post-depositional mobility of As near the sediment-water interface.

Our results also reveal that the disparity in the significance of relative As influence on the arcellinidan ecology in each lake may have developed due to the variance in the dominant As mineralization in Frame Lake $\left(\mathrm{As}_{2} \mathrm{O}_{3}\right)$ and Hambone Lake (As-sulphides), which is in turn related to the documented difference in oreprocessing practices at the former Giant (roasting) and Tundra mines (freemilling). Results from this study provide the quantitative evidence for the sensitivity of Arcellinida to varying levels of As contamination derived from different As mineral forms and showcases the potential of using this group as a reliable tool for monitoring As contamination, lacustrine ecological health, and the progress of remedial efforts in impacted lakes. These results are also significant as they showcase the potential of using Arcellinida as a reconnaissance tool to discriminate the dominant As mineral forms, which in turn will further guide and refine the selection of impacted lakes for As speciation analysis. 


\subsection{Acknowledgments}

Funding for this project was provided by NSERC Discovery grant to RTP, a Polar Knowledge Canada grant to RTP and JMG, two grants from Tides Canada, an Entrepreneur Support (SEED) grant from the City of Yellowknife, the Royal Bank of Canada Blue Water Fund, NWT Cumulative Impact Monitoring Fund (CIMP), The Giant Mine Remediation Project Team, and Trout Unlimited. Additional funding was provided from the Northern Science Training Program (NSTP) grant and Geological Society of America Research Grant (GSA) to NAN. We acknowledge

Dr. Andrew L. Macumber and Clare Miller (Queen's University, Ontario) for their help with sample collection at Frame Lake in 2014 and Hambone Lake in 2016, respectively. We also thank Stephane Aube (Carleton University) for assisting with samples preparation. Our thanks are extended to JJ Wang (Carleton University) for his help with SEM imaging of Arcellinida tests specimens. We would like to thank CIRNAC, Delta Engineering, and Nahanni Construction for their hospitality and kind support during the summer field season of 2016 at the former Tundra Mine site. This research work represents NRCan Contribution Number XXXX.

\subsection{References}

AANDC, 2014. Tundra Mine, NWT Remediation Environmental Monitoring Program: Water Quality Part L: 2013 and Historic Results. Available online: http://registry.mvlwb.ca/Documents/MV2009L8-0008/MV2009L80008\%20-\%20AANDC-CARD\%20- 
\%202013\%20Annual\%2oReport\%2ofor\%20Tundra\%2oMine\%20Site\%20 -\%20Mar27-14.pdf

AECOM, 2015. Tundra Mine, NWT Remediation Environmental Monitoring Program: Water Quality Part L: 2014 and Historical Results. Available online: $\quad$ http://registry.mvlwb.ca/Documents/MV2009L80008/MV2009L8-0008\%20-\%20AANDC-CARD\%20\%20Tundra\%20Mine\%202014\%20Annual\%20WL\%20Report\%20\%20May5-15.pdf

AECOM, 2018. Tundra Mine Adaptive Management Plan. Available online: http://registry.mvlwb.ca/Documents/MV2016L8-0003/MV2016L8-0003 - INAC CARD - Adaptive Management Plan - Revision from May 24-18 Oct26-18.pdf

Andrade CF, Jamieson HE, Praharaj T, Fortin D, Kyser TK, 2010. Biogeochemical cycling of arsenic in mine-impacted sediments and co-existing pore waters. Applied Geochemistry 25:199-211.

Anneville O, Gammeter S, Straile D, 2005. Phosphorus decrease and climate variability: mediators of synchrony in phytoplankton changes among European peri-alpine lakes. Freshwater Biology 50:1731-1746.

Asioli A, Medioli FS, Patterson RT, 1996. Thecameobians as a tool for reconstruction of paleoenvironments in some Italian lakes in the foothills of the southern Alps (Orta, Varese and Canada). Journal of Foraminiferal Research 26:248-263. 
Behbehani AR, Müller J, Schmidt R, Schneider J, Schröder HG, Strackenbrock I, Sturm, M, 1986. Sediments and sedimentary history of Lake Attersee (Salzkammergut, Austria). Hydrobiologia 143: 233-246.

Berthon V, Alric B, Rimet F, Perga ME, 2014. Sensitivity and responses of diatoms to climate warming in lakes heavily influenced by humans. Freshwater Biology 59(8):1755-67.

Beyens L, Chardez D, De Bock P, 1986. Some new and rare testate amoebae from the Arctic. Acta Protozoologica 25:81-91.

Bleeker W, Ketchum JWF, Jackson VA, Villeneuve ME, 1999. The Central Slave Basement Complex, Part I: its structural topology and autochthonous cover. Canadian Journal Earth Science. 36:1083-1109.

Blott SJ, Pye K, 2001. GRADISTAT: A grain size distribution and statistics package for the analysis of unconsolidated sediments. Earth Surf Process Landforms 26:1237-1248.

Boström B, Persson G, Broberg B, 1988. Bioavailability of different phosphorus forms in freshwater systems. Hydrobiologia 170:133-155.

Brembu T, Mühlroth A, Alipanah L, Bones AM, 2017. The effects of phosphorus limitation on carbon metabolism in diatoms. Philosophical Transactions of the Royal Society B: Biological Sciences. 17:372(1728). 
Canadian Council of Ministers of the Environment (CCME), 2002. Canadian Sediment Quality Guidelines for the Protection of Aquatic Life, in, Canadian Environment Quality Guidelines.

Cattaneo A, Couillard Y, Wunsam S, Courcelles M, 2004. Diatom taxonomic and morphological changes as indicators of metal pollution and recovery in Lac Dufault (Québec, Canada). Journal of Paleolimnology 32(2):163-175.

Carter HJ, 1856. Notes on the fresh water Infusoria of the island of Bombay. Annals Magazine of Natural History 18:221-249.

Caussy D, Priest ND, 2008. Introduction to As contamination and health risk assessment with special reference to Bangladesh. InReviews of Environmental Contamination 197:1-15.

Charman DJ, 2001. Biostratigraphic and palaeoenvironmental applications of testate amoebae. Quaternary Science Reviews 20(16-17):1753-1764

Collins ES, McCarthy FM, Medioli FS, Scott DB, Honig CA, 1990. Biogeographic distribution of modern thecamoebians in a transect along the eastern North American coast. In: Hemleben C, Kaminski MA, Kuhnt W, Scott DB (Eds.), Paleoecology, Biostratigraphy, Paleoceanography and Taxonomy of Agglutinated Foraminifera. NATOAdvanced Study Institute Series, Series C, Mathematical and Physical Sciences 327:783-791.

Core Team R, 2014. R: A Language and Environment for Statistical Computing. Available at: http://www.r-project.org (accessed 16 June, 2019). 
Cousens BL, 2000. Geochemistry of the archean Kam group, Yellowknife greenstone belt, Slave Province, Canada. Canadian Journal of Geology 108:181-197.

Dalby AP, Kumar A, Moore JM, Patterson RT, 2000. Utility of arcellaceans (thecamoebians) as paleolimnological indicators in tropical settings: Lake Sentani, Irian Jaya, Indonesia. Journal of Foraminiferal Research 30:135142.

Dillion-Leitch HC, 1981. Volcanic stratigraphy, structure and metamorphism in the Courageous-Mackay Lake Greenstone Belt, Slave Province, Northwest Territories. University of Ottawa.

Dirszowsky RW, Wilson KM, 2013. Supplementary report on the sedimentary record of Frame Lake, City of Yellowknife,Northwest Territories-the FLo5 Diatom Record. Report pre- pared for Fish Habitat Management, Western Arctic Area; Cen- tral and Arctic Region; Fisheries and Oceans Canada

Dirszowsky RW, Wilson KM, 2016. Biogeochemical evidence of eutrophication and metal contamination of Frame Lake, City of Yellowknife, Northwest Territories, Canada. Environmental Earth Sciences 75:76.

Dixit SS, Dixit AS, Smol JP, 1989. Lake Acidification Recovery can be Monitored using Chrysophycean Microfossils. Canadian Journal of Fisheries and Aquatic Sciences, 46:1309-1312. 
Du Ling G, Chapagain SK, Dewispelaere M, Meer E, Kazama F, Tack FGM, Rinklebe J, Verloo MG, 2009. Presence and mobility of arsenic in estuarine wetland soils of the Scheldt estuary (Belgium). Journal of Environmental Monitoring 11:873-881.

Dujardin F, 1837. Sur une nouvelle espèce de Gromia et sur les Difflugies. Annales des sciences Naturelles, Zoologie, ser. 2,8:310-313.

Ehrenberg CG, 1832. Über die Entwicklung und Lebensdauer der Infusionsthiere, nebst ferneren Beitra"gen zu einer Vergleichung ihrer organischen Systeme. Königliche Akademie der Wissenschaften zu Berlin Physikalische Abhandlungen, 1931:1-154.

Ehrenberg CG, 1843. Verbreitung und Einfluss des mikroskopischen Lebens in Su"d-und Nord Amerika: Ko"nigliche Akademie der Wissenschaften zu Berlin Physikalische Abhandlungen 1841:291-446

Ehrenberg CG, 1838. Die Infusionstierchen als vollkommene Organ-ismen. L. Voss, Leipzig.

Environment Canada, 2019. National Climate Data and Information Archive, Canadian Climate Normals or Averages 1981-2010, Yellowknife A, Northwest Territories; Environment Canada, <http://www.climate.weatheroffice.gc.ca> [accessed March 10, 2019]. 
Galloway JM, Palmer M, Jamieson HE, Patterson RT, Nasser N, Falck H, Macumber AL, Goldsmith SA, Sanei H, Normandeau P, Hadlari T, Roe HM, Neville LA, Lemay D, 2015. Geochemistry of lakes across ecozones in the Northwest Territories and implications for the distribution of arsenic in the Yellowknife region. Part 1: Sediments; Geological Survey of Canada, Open File 2015, 7908, 50 p. + appendix, 1 .zip file.

Galloway JM, Swindles GT, Jamieson HE, Palmer M, Parsons MB, Sanei H, Macumber AL, Patterson RT, Falck H, 2018. Organic matter control on the distribution of arsenic in lake sediments impacted by $\sim 65$ years of gold ore processing in subarctic Canada. Science of the Total Environment 622:1668-1679.

Gavel MJ, Patterson RT, Nasser NA, Galloway JM, Roe HM, Cott PA, Ellis S, 2018. What killed Frame Lake? A precautionary tale for urban planners. PeerJ 6:e4850.

Gibson JJ, Reid R. 2014. Water balance along a chain of tundra lakes: A 20-year isotopic perspective. Journal of Hydrology 519:2148-2164.

Hatfield Consulting, 1982. Initial Environmental Evaluation for Giant Yellowknife Mines - Salmita Project. Unpublished report prepared for Giant Yellowknife Mines Ltd., Yellowknife, NT. pp. 1-24.

Healey MC, Woodall WL, 1973. Limnological Surveys of the seven lakes near Yellowknife, Northwest Territories. Fisheries Research Board of Canada Fresh Water Institute, Technical report 37 
Heiri O, Lotter AF, Lemcke G, 2001. Loss on ignition as a method for estimating organic and carbonate content in sediments: reproducibility and comparability of results. Journal of paleoclimnology 25(1):101-110.

Hotelling H, 1933. Analysis of a Complex of Statistical Variables Into Principal Components. Journal of Educational Psychology 24:417-441 and 498-520.

INAC, 2005. Tundra Mine, NWT Environmental Monitoring Program: Water Quality Part D: 2005 Results. Prepared for: Contaminants and Remediation Directorate, Indian and Northern Affairs Canada. Available online: http://registry.mvlwb.ca/Documents/MV2005Xo031/PartDWaterQualityMon-Novo5.pdf

INAC, 2002. Mine Site Reclamation Policy for the Northwest Territories. Indian and Northern Affairs Canada. Available online: https://www.lands.gov.nt.ca/sites/lands/files/resources/mine_site_recla mation_policy_-_nwt.pdf

INAC, 2009. Contaminated Sites Remediation: What is Happening in areas with Ongoing Land and Resource Negotiations in the NWT. Indian and Northern Affairs Canada. $\quad$ Available online: http://publications.gc.ca/collections/collection_2010/ainc-inac/R12-282009-1-eng.pdf

International Commission on Zoological Nomenclature, 1999. International code of zoological nomenclature, 4th edn. The Natural History Museum, London, p 338. 
Kelts K, Ksü KJ, 1978. Freshwater carbonate sedimentation. In Lakes: chemistry, geology, physics. Edited by A.L. Lerman. Springer-Velag, New York. pp. 295-323.

Kerr DE, Wilson P, 2000. Preliminary surficial geology studies and mineral exploration considerations in the Yellowknife area, Northwest Territories. Geology Survey Canada Current Research C3, p 8.

Kihlman SM, Kauppila T, 2012. Effects of mining on testate amoebae in a Finnish lake. J Paleolimnol 47:1-15.

Kruskal JB, 1964. Non-metric multidimensional scaling: A numerical method. Psychometrika, 29:115129.

Kumar A, Patterson RT, 2000. Arcellaceans (thecamoebians): new tools for monitoring long-term and short-term changes in lake bottom acidity. Environ Geol 39:689-697.

Lamarck JB, 1816. Histoire Naturelle des Animaux sans Vèrtèbres. Verdièie, Paris, tome 2, p. $1-568$

Last WM, Smol JP (eds), 2001. Tracking environmental change using lake sediments. Physical and geochemical methods, vol 2. Kluwer, Dordrecht.

Lorax Environmental. 2007. Tundra Mine Geochemical Assessment. Pp. 1 - 105. Internal report of Paleolimnology 40(2):603-618. 
Magurran AE, 1988. Ecological diversity and its measurement. Princeton University Press, Princeton, 185 pp.

Medioli FS, Scott DB, 1983. Holocene Arcellacea (Thecamoebians) from eastern Canada. Cushman Foundation for Foraminiferal Research special Publication 21:63

Medioli FS, Scott DB, 1988. Lacustrine thecamoebians (mainly arcellaceans) as potential tools for palaeolimnological interpretations. Palaeogeogr Palaeoclimatol Palaeoecol 62(1-4):361-386.

Menard E, Nasser NA, Patterson RT, Galloway JM, Cott PA, Hanna BW, Falck H, 2019. Sub-bottom acoustic profiling as a remediation assessment tool for contaminated lakes. SN Applied Sciences. 1;1(6):572.

Miller CB, Parsons MB, Jamieson HE, Swindles GS, Nasser NA, Galloway JM, 2019. Lake-specific controls on the long-term stability of mining-related As contamination and geochemical baselines in a changing northern environment, Tundra Mine, Northwest Territories, Canada. Applied Geochemistry 16:104403.

Mitchell EA, Payne RJ, Lamentowicz M, 2008. Potential implications of differential preservation of testate amoeba shells for paleoenvironmental reconstruction in peatlands. Journal of Paleolimnology 40:603-618.

Moore JCG, 1951. Courageous Lake; Geological Survey of Canada Paper 51-14. 
Murray M. 2002. Is laser particle size determination possible for carbonate-rich lake sediments? Journal of Paleolimnology 27:173-183.

Nasser NA, Patterson RT, Galloway JM, Roe HM, Neville LA, Macumber AL, Sanei H, Patterson RT, Palmer MJ, Spence C, 2016. Lacustrine Arcellinina (Testate Amoebae) as Bioindicators of Arsenic Contamination. Microbial Ecology 72(1):130-149.

Nasser NA, Patterson RT, 2015. Conicocassis, a new genus of Arcellinina (testate lobose amoebae). Palaeontol Electron 18:1-11.

Natural Resources Canada. 2019. Annual Statistics of Mineral Production. Natural Resources Canada. online: http://sead.nrcan.gc.ca/prod-prod/ann-anneng. $\operatorname{aspx}$ ?FileT=2018\&Lang=en [accessed July 20, 2019]

Neville LA, McCarthy FMG, MacKinnon MD, Swindles GT, Marlowe P. 2011. Thecamoebians (testate amoebae) as proxies of ecosystem health and reclamation success in constructed wetlands in the oil sands of Alberta, Canada. Journal of Foraminiferal Research 41:230-247.

Neville LA, Patterson RT, Gammon P, Macumber AL, 2014. Relationship between ecological indicators (Arcellacea), total mercury concentrations and grain size in lakes within the Athabaska Oil Sands region, Alberta. Environmental Earth Sciences 72:577-588. 
Olsen SR, Cole CV, Watanabe FS, Dean LA, 1954. Estimation of available phosphorus in soils by extraction with sodium bicarbonate. In USDA Circular No. 939. U.S. Govt. Printing Office, Washington, DC. pp. 1-19.

Otsuki A, Wetzel RG, 1974. Calcium and toal alkalinity budgets and calcium carbonate precipitation of a small hard-water lake. Archiv fur Hydrobiologie 73:14-30.

Parsons M, LeBlanc KWG, Hall GEM, Sangster AL, Vaive JE, Pelchat P, 2012. Environmental geochemistry of tailings, sediments and surface waters collected from 14 historic gold mining districts in Nova Scotia. Geological Survey of Canada, Open File 7105 (326 p).

Palmer M, Galloway JM, Jamieson HE, Patterson RT, Falck H, Kokelj SV, 2015. The concentration of arsenic in lake waters of the Yellowknife area 15 years after the end of gold ore processing. Northwest Territories. Geological Survey Open File 2015, 16.

Palmer MJ, Chételat J, Richardson M, Jamieson HE, Galloway JM, 2019. Seasonal variation of arsenic and antimony in surface waters of small subarctic lakes impacted by legacy mining pollution near Yellowknife, NT, Canada. Science of the Total Environment 684:326-339.

Patterson RT, 2014. Mediolus, a new genus of Arcellacea (Testate Lobose Amoebae). Palaeontologia Electronica. 17.2.28A. 8 p. 
Patterson RT, Baker T, Burbridge SM, 1996. Arcellaceans (thecamoebians) as proxies of arsenic and mercury contamination in northeastern Ontario lakes. Journal of Foraminiferal Research 26:172-183.

Patterson RT, Fishbein E, 1989. Re-examination of the statistical methods used to determine the number of point counts needed for micropaleontological quantitative research. Journal of Paleontology 63:245-248.

Patterson RT, Kumar A, 2002. A review of current testate rhizopod (thecamoebian) research in Canada. Palaeogeogr Palaeoclimatol Palaeoecol $180(1-3): 225^{-251 .}$

Patterson RT, Roe HM, Swindles GT, 2012. Development of an Arcellacea (testate lobose amoebae) based transfer function for sedimentary phosphorus in lakes. Palaeogeography, Palaeoclimatology, Palaeoecology. 2012 Sep $1 ; 348: 32-44$.

Patterson RT, Lamoureux ED, Neville LA, Macumber AL, 2013. Arcellacea (testate lobose amoebae) as $\mathrm{pH}$ indicators in a pyrite mine-acidified lake, Northeastern Ontario, Canada. Microbial ecology 65(3):541-554.

Patterson RT, Huckerby G, Kelly TJ, Swindles GT, Nasser NA, 2015. Hydroecology of Amazonian lacustrine Arcellinida (testate amoebae): A case study from Lake Quistococha, Peru. European Journal of Protistology 51:460-469.

Penard E, 1890. Etudes sur les rhizopodes d'eau douce. Memoires de la Société de physique et d'histoire naturelle de Genève 31:1-230. 
Penard E, 1902. Faune Rhizopodique du Bassin du Lèman. Henry Kündig, Libraire de L’institut, Genéve pp 712

Pearson K, 1901. On lines and planes of closest fit to systems of points in space, Philosophical Magazine 2:559-572.

Plumlee GS, Morman SA, 2011. Mine wastes and human health. Elements 7:399404.

Ransom A, Robb M, 1986. The Salmita gold deposit, Courageous Lake, Northwest Territories. In: L.A. Clark and D.R. Francis (Editors), Gold in the Western Shield. Canadian Institute of Mining 38:285-305.

Reid R, 2012. Water Balance Monitoring at the Tundra Mine Site: 2012 Update Prepared for: Contaminants and Remediation Directorate. Aboriginal Affairs and Northern Development Canada. Available online: http://registry.mvlwb.ca/Documents/MV2009L8-0008/MV2009L80008\%20-\%20AANDC\%20-\%20CARD\%20\%20Tundra\%20Minesite\%202012\%2oWL\%20Annual\%2oReport\%2O\%20Mar28-13.pdf

Reinhardt EG, Dalby AP, Kumar A, Patterson RT, 1998. Arcellaceans as pollution indicators in mine tailing contaminated lake near Cobalt, Ontario, Canada. Micropaleontol 44:131-148. 
Reimann C, Filzmoser P, Garrett RG, Dutter R, 2008. Statistical Data Analysis Explained: Applied Environmental Statistics with R. John Wiley \& Sons, Ltd. ISBN: 978-0-470-98581-6

Risklogic Scientific Services Inc., 2002. Determining Natural (Background) Arsenic soil concentrations in Yellowknife NWT and deriving site-specific human health-based remediation objectives for arsenic in the Yellowknife Area: final report

Roe HM, Patterson RT, 2006. Distribution of thecamoebians (testate amoebae) in small lakes and ponds, Barbados, West Indies. The Journal of Foraminiferal Research 36(2):116-134.

Roe HM, Patterson RT, Swindles GT, 2010. Controls on the contemporary distribution of lake thecamoebians (testate amoebae) within the Greater Toronto Area and their potential as water quality indicators. Journal of Paleolimnology 43(4):955-975.

Schuh CE, Jamieson HE, Palmer MJ, Martin AJ, 2018. Solid-phase speciation and post-depositional mobility of arsenic in lake sediments impacted by ore roasting at legacy gold mines in the Yellowknife area, Northwest Territories, Canada. Applied Geochemistry 91:208-220S.

Scott DB, Hermelin JOR, 1993. A device for precision splitting of micropaleontological samples in liquid suspension. Journal of Paleontology $67: 151-154$ 
SENES Consultants Limited (SENES), 2005. Air quality moni- toring at Giant Mine site- Yellowknife: a baseline study. In: INAC (2007): Giant Mine Remediation Plan, supporting document A11. 67pp

SENES Consultants Ltd., 2006. Tundra Mine Site Ecological Risk Assessment of Water Management. Available online: http://www.mvlwb.ca/Registry.aspx?a=MV2009L8-00o8

SENES Consultants Ltd., 2011. Development of Tundra Mine construction monitoring, long-term monitoring, and status of the environment programs. Available online: http://www.mvlwb.ca/Registry.aspx?a=MV2009L8-00o8

Shannon CE, 1948. A mathematical theory of communication. The Bell Syst Tech $\mathrm{J}$ 27:379-423 and 623-656.

Siddorn JP, Cruden AR, Hauser RL, Armstrong JP, Kirkham G, 2007. The GiantCon gold deposits: preliminary integrated structural and mineralization history. In: Anglin CD, Falck H, Wright DF, Ambrose EJ (eds) Gold in the Yellowknife Green- stone Belt, Northwest Territories: Results of the EXTECH III Multidisciplinary Research Project. Geological Association of Canada, Mineral Deposits Division, St. John's, pp 213-231.

Siemensma FJ, 2019. Microworld, world of amoeboid organisms. World-wide electronic publication, Kortenhoef, the Netherlands. Online: https://www.arcella.nl/ [accessed June 3, 2019] 
Silke R, 2009. The operational history of mines in the Northwest Territories. Canada An Historical Research Project. Available online: https://buyandsell.gc.ca/cds/public/2014/o5/27/edcb878b7f96e1d3oe53 59a53406c671/ABES.PROD.PW_NCS.B107.E10183.ATTA040.PDF

Sivarajah B, Korosi JB, Blais JM, Smol JP, 2019. Multiple environmental variables influence diatom assemblages across an arsenic gradient in 33 subarctic lakes near abandoned gold mines.

Smith DG, 1994. Glacial lake McConnell: paleogeography, age, duration, and associated river deltas, Mackenzie river basin, western Canada. Quaternary Science Reviews 13:829-843.

Steele RE, Nasser NA, Patterson RT, Gregory BR, Roe HM, Reinhardt EG, 2018. An Assessment of Sub-Meter Scale Spatial Variability of Arcellinida (Testate Lobose Amoebae) Assemblages in a Temperate Lake: Implications for Limnological Studies. Microbial ecology 76:680-694.

Stubley MP, 1997. Geological complication of Carp Lake area, NTS 85P and southeastern 85O; EGS 1997-07, NWT Geology Division, Indian and Northern Affairs Canada, Yellowknife, scale 1:250 000

Tides Canada, 2015. Frame Lake Rehabilitation Project receives RBC Blue Water Fund support. online: https://tidescanada.org/in-the-news/frame-lakerehabilitation-project-receives-rbc-blue-water-fund-support/ [accessed August 18, 2019] 
Thienpont JR, Korosi JB, Hargan KE, Williams T, Eickmeyer DC, Kimpe LE, Palmer MJ, Smol JP, Blais JM, 2016. Multi-trophic level response to extreme metal contamination from gold mining in a subarctic lake. Proceedings of the Royal Society B: Biological Sciences 283:20161125.

Toevs GR, Morra MJ, Polizzotto ML, Bostick BC, Fendorf SE, Strawn DG, 2006. Metal(loid) diagenesis in mine-impacted sediment of Lake Coeur d'Alene, Idaho. Environmental Science and Technology 40:2537-2543.

Topographical Survey of Canada, 1925. Map of Lockhart River Basin, Great Slave Lake District, Northwest Territories: including the head waters of Thelon, Back and Coppermine Rivers. Available online: https://brbldl.library.yale.edu/vufind/Record/4199064

van Hengstum P, Reinhardt E, Boyce JI, Clark C, 2007. Changing sedimentation patterns due to historical land-use change in Frenchman's Bay, Pickering, Canada: evidence from high-resolution textural analysis Journal of Paleolimnology 37:603-618.

van den Wollenberg AL, 1977. Redundancy analysis. An alternative for canonical correlation analysis. Psychometrika 42:207-219.

Van Den Berghe MD, Jamieson HE, Palmer MJ, 2018. Arsenic mobility and characterization in lakes impacted by gold ore roasting, Yellowknife, NWT, Canada. Environmental Pollution 234:630-641. 
Ward JH. 1963. Hierarchical grouping to optimize an objective function. Journal of American Statistical Association 58:236-244.

World Commission on Environment and Development (WCED), 1987. Our Common Future. Oxford and New York: Oxford University Press.

Wrye LA, 2008. Distinguishing between Natural and Anthropogenic Sources of Arsenic in Soils from the Giant Mine, Northwest Territories, and the North Brookfield Mine, Nova Scotia. M.Sc. Thesis. Queen's University.

Zhou Q, Gibson CE, Zhu Y, 2001. Evaluation of phosphorus bioavailability in sediments of three contrasting lakes in China and the UK. Chemosphere $42: 221-225$. 


\section{Chapter 6}

\section{Conclusions}

This integrated Ph.D. dissertation has been based on four research projects, represented as articles that are published (Chapter 2 and Chapter 3) or submitted for peer-review (Chapter 4 and Chapter 5). This thesis was designed to further develop Arcellinida as a robust tool for monitoring changes in As contamination, lacustrine ecological health, and the progress in remediation in lake impacted by gold mining-derived As contamination in the central NT, Canada. Results from this dissertation, therefore, directly support the long-term objectives of a multidisciplinary and collaborative POLAR- and GSC-funded project that aimed to develop robust geoscience tools for assessing environmental risk associated with metal mining in northern Canada.

\subsection{A novel Arcellinida sample processing}

\section{protocol}

The first stage in developing Arcellinida as a reliable biomonitoring tool for As involved designing and testing a novel sample processing protocol for reducing the organic content in lake sediment samples, and therefore enhance the quality and

efficiency of Arcellinida analysis (Nasser et al., 2019; Chapter 2). The impact of using three chemical deflocculation methods (soda ash, $\mathrm{KOH}$, and sodium 
hexametaphosphate) on: 1) organic content reduction; 2) arcellinidan test integrity; and, 3) test retention and Arcellinida analysis quality in 126 aliquots from three near-surface lacustrine sediment samples was assessed. The results of this study reveal that:

1. Treatment with $5 \% \mathrm{KOH}$ reduced the highest proportion of organic content, while causing acceptable level of damage to Arcellinida tests that did not hinder micropaleontological analysis;

2. The treatment led to the identification and enumeration of higher numbers of arcellinidan tests $(47.5-452.7 \%$ increase in tests retention in organicrich aliquots and $14.8 \%$ in aliquots with less organic content); and,

3. The faunal structure of the Arcellinidan assemblages identified in $5 \% \mathrm{KOH}-$ treated and control sub-samples were relatively consistent, indicating that the faunal structure of these assemblages was not impacted by the chemical treatment.

These results suggest that $5 \% \mathrm{KOH}$ treatment of Arcellinida sediment samples is an effective method for enhancing the efficiency of Arcellinida analysis and the quality of the generated data by reducing residual organic matter that is often found in lake sediment samples. Improving the quality of data generated from Arcellinida analysis is particularly significant in order to ensure that the reliability and consistency of using the group as a biomonitoring tool. 


\subsection{Arcellinida assemblages homogeneity and inter-annual dynamic}

Assessing Arcellinida assemblages faunal homogeneity in similar lacustrine environments and their response to short-term environmental changes (i.e., interannual) was another avenue of research that was investigated to further develop the group as a reliable monitoring tool in general, and bioindicators of As in specific (Nasser et al., 2019; Chapter 3). This approach is used to evaluate how representative analyzing one, or few, near-surface sediments are in a lake for Arcellinida. Commonly only a single sample is collected and analyzed per lake. Arcellinida species and strains were examined in 22 surface-sediment samples from similar limnological environments in selected single basin in Lac du Castor Blanc (Quebec) and Oromocto Lake (New Brunswick). The findings of the study are listed below:

1. The faunal composition of Arcellinida assemblages found in lacustrine sites of similar limnological conditions was homogenous. This finding suggests that duplicate sampling from similar lake environments may not be necessary to identify Arcellinida assemblage representative of the targeted lake environments, which is in turn significant when designing sampling strategies of intra- and inter-lake for environmental monitoring programs;

2. Cluster analysis (supported with PVClust analysis) and BCDM results led to the identification of two distinct sub-assemblages in Oromocto Lake (OL10 and OL12) that corresponds to the year the sample were collected 
(2010 CE and $2012 \mathrm{CE}$ ) within the same region of Wightman Cove, Oromocto Lake; and,

3. The OL12 sub-assemblage was characterized by higher proportions of the healthy-lake-indicating diffluggiid taxa compared to the OL10 subassemblage sample, likely due to a subtle increase in lake organic content in $2012 \mathrm{CE}$.

The observed faunal homogeneity of Arcellinida assemblages coupled with their sensitivity to subtle inter-annual changes in lake environmental conditions in Wightman Cove, therefore, provides confirmation that Arcellinida can be successfully used as a tool for monitoring limnological change at short-term time scales.

\subsection{Quantifying the relationship between}

\section{Arcellinida and As}

\subsubsection{Inter-lake spatial survey}

To quantify the relationship between Arcellinida and As, Arcellinida specimens were examined in 93 near-surface samples from 90 lakes located within a radius of $\sim 30 \mathrm{~km}$ around the former Giant Mine and the City of Yellowknife, NT, Canada. The primary objectives of this project were to determine whether Arcellinida assemblages can be used to delineate the spatial extent of As contamination in the Yellowknife area, and determine the As tolerance limits of the identified Arcellinida species and strains. The study reveals the following: 
1. Redundancy analysis shows that $40.4 \%$ of the variance in the identified Arcellinida assemblages is explained by ten variables, with As being the most statistically significant (variance explained $=9.4 \% ; p$-value $=0.001$ );

2. The identified Arcellinidan assemblages $(n=5)$ exhibited a clear faunal shift from stressed assemblages in lakes near the mine $(<10 \mathrm{~km})$ to healthier assemblages in lakes located $>10 \mathrm{~km}$ from the mine site, which is consistent with the spatial extent of the airborne As contamination zone of immediate impact delineated by previous regional assessments of the spatial distribution of As in lake1 water (Palmer et al., 2015) and sediment samples (Galloway et al., 2017); and,

3. Three arcellinidan groups based on As tolerance limits were statistically identified. Two of the three groups were successfully used to infer As concentrations in 20 out of $30(66.6 \%)$ freeze core samples impacted by mine-induced As regardless of As post-depositional remobilization

The results of this study establish the utility of arcellinidan as bioindicators for monitoring changes in As concentrations and the ecological health in lakes impact by mine-induced As contamination.

\subsubsection{Intra-lake spatial survey}

This research quantified, for the first time, the intra-lake relationship between Arcellinida fauna and variability of As derived from two former gold mines through analysis of 40 near-surface sediment samples from Frame Lake $(n=25)$ in the 
Yellowknife area, and Hambone Lake in the Courageous Lake region in the central NT $(n=15)$. The findings of the study are listed below:

1. Based on the redundancy analysis (RDA) and variance portioning analysis, seven variables controlled the arcellinidan distribution in Frame Lake (As, Olsen $\mathrm{P}, \mathrm{Ca}$, and silt and sand particle size fractions; total variance explained $=43.2 \%$ ) and Hambone Lake (silt particle size fraction, LOIdetermined minerogenic content, $\mathrm{Ba}$, and As; total variance explained = $58.4 \%)$

2. Arsenic was found to be the most statistically significant control over the distribution of Arcellinida in Frame Lake (variance explained = 15.8\%; $p$ value $=0.001$, while being statistically insignificant in Hambone Lake (7.6\%; $p$-value $=0.152)$

3. In Frame Lake, stress-indicating assemblages were associated with elevated As levels, while healthier assemblages were linked to low As concentrations and a higher influence of nutrient loading controls like Olsen P (10.5\%; $p$ value $=0.004)$ and $\mathrm{Ca}(9.5 \% ; p$-value $=0.003)$

4. In Hambone Lake, a major increase in the proportion of stress-indicting Arcellinida taxa near the lake's outlet is consistent with recently recognized spatial patterns attributed to the post-depositional mobility of As near the sediment-water interface. This result suggests that As, while statistically insignificant as a control, is still impacting the Arcellinida populations in Hambone Lake, albeit at a lower magnitude compared to its influence in Frame Lake; 
5. The disparity in the significance of As influence on the arcellinidan ecology in each lake may be attributed to the influence of different As mineral forms in Frame Lake $\left(\mathrm{As}_{2} \mathrm{O}_{3}\right)$ and Hambone Lake (As-sulphides), which is in turn related to the difference in ore-processing practices at the former Giant (roasting) and Tundra mines (free-milling);

Results from this study provide the quantitative evidence for the sensitivity of Arcellinida to varying levels of As contamination derived from different As mineral forms and showcases the potential of using this group as a reliable tool for monitoring As contamination, lacustrine ecological health, and the progress of remedial efforts in impacted lakes. The discrimination of varying As mineral forms through assessing Arcellinida assemblages dynamics is particularly significant for environmental monitoring initiative as it can assist with identifying lakes were As is possibly more bioavailable due to the nature of the dominant source As mineralization. Such lakes can then be targeted for more sophisticated geochemical analysis (i.e. As speciation).

\subsection{Potential Areas of Future Work}

The objectives of this Ph.D. research, listed in Chapter 1, were successfully achieved. However, there remains several questions and research directions that can be investigated to further refining the use of Arcellinida as a geoscience tool for monitoring mine-derived As contamination. General recommendations for potential areas of future research work are discussed below: 
Peatland testate amoebae studies that used chemical treatment to reduce the organic content of samples often resorted to heating chemically treated samples on a hot plate to accelerate the deflocculation process (e.g., Ellison and Ogden, 1978). It is recommended to investigate the impact of heating $5 \% \mathrm{KOH}$-treated samples on the duration of treatment, reduction of organic matter, damage to arcellinidan tests, and test retention and compare these findings with the results generated from treating sample without heating. Heating chemically treated Arcellinida sediment samples have the potential of further improving the efficiency of the chemical treatment protocol, by substantially reducing treatment duration, given that Arcellinida tests are intact post heating.

* Treatment of lake sediment samples with $5 \% \mathrm{KOH}$ proved to be effective in reducing more organic matter when the total organic content of samples is greater than $20 \%$. However, the value of total organic matter below which chemical treatment is not necessary can be further refined by testing the effects of $5 \% \mathrm{KOH}$ treatment on sample with a wider gradient of total organic content. Determining such organic content "cutoff" value will refine the decision of whether using traditional or chemical sample preparation methods is more appropriate for reducing the organic content of Arcellinida sediment samples.

* Wall et al. (2010) demonstrated that filter mesh size affects Arcellinida abundance, species richness, and assemblage structure. It is recommended that the impact of combining $5 \% \mathrm{KOH}$ treatment with various sieve mesh sizes, and sieving durations, on the reduction of organic matter and 
retention of Arcellinidan tests is assessed and quantified. Determining the optimal combination of chemical treatment and sieving may lead to further refining the sample processing protocol and potentially reducing the processing time.

* The results of this dissertation confirm the homogeneity of Arcellinida assemblages in sediment samples from similar lake environments. However, lake sediments are often heterogenous in composition (Last and Smol, 2001). It is recommended that the assessment of the homogeneity of Arcellinida assemblages is extended to include multiple lake environments and trophic states in order to determine if such environments are represented by a specific Arcellinida taxon or dominated by distinct Arcellinida assemblages. Identifying such further enhance the reliability of using Arcellinida for monitoring environmental change in lakes.

* Arcellinida assemblages from similar lacustrine environments proved to be responsive to inter-annual changes in environmental conditions. Future work to further confirm the reliability of using the group as a tool for monitoring tool must involve coupling analysis of Arcellinida assemblage response to inter-annual and seasonal lake variations in order to identify any subtle patterns in Arcellinida assemblage dynamics. Such study design can be carried out by employing a seasonal intra-lake sampling approach that targets certain sites within selected lakes. Such assessments of seasonal changes in the arcellinidan assemblage structure may provide a mean to assess subtle transitions in Arcellinida abundance, species richness, and faunal composition in response to subtle changes in multiple 
parameters (e.g., sedimentological, geochemical, organic, and lake parameters).

* The findings of this dissertation confirm a significant response of lacustrine Arcellinida to mine-induced Arsenic contamination. However, impacted lakes and mines investigated in the dissertation are exclusively located in higher latitudes. Several studies (e.g., Dalby et al., 2000; Roe and Patterson, 2006) have shown that Arcellinida assemblage composition and dynamics in lower latitudes differed than that in higher latitudes lakes. It is, therefore, essential to also quantify the intra- and inter-lake relationship between Arcellinida and gold-mine derived As contamination in multiple low-latitude impacted regions to assess the reproducibility of the results of this thesis and further refine the As tolerance limits of Arcellinida taxa.

* Supplement the spatial investigations of As impact on Arcellinida with high-resolution down-core assessments to quantify the temporal response of Arcellinida to As. A recent study by Gavel et al (2018) demonstrated the sensitivity of Arcellinida to temporal variations in As concentrations. The study, while proving new insight to the impact of As on Arcellinida assemblages' dynamics, was only semi-quantitative in nature and was conducted at a coarse temporal resolution $(1 \mathrm{~cm})$. High-resolution downcore assessment can be achieved through combining the use of freeze coring, to collect undisturbed and continuous sedimentary records, and a custom-build sledge microtome to achieve high-resolution sub-sampling (temporal resolution of $1 \mathrm{~mm}$ ). Assessing the response of Arcellinida 
down-core variation in As levels at a higher resolution is imperative for confirming the sensitivity of Arcellinida to subtle variations in As levels especially those pertaining to post-depositional mobility of As.

* Results of this dissertations suggest the possibility of a direct and/or indirect impact of As contamination on the abundance, diversity, and spices richness of Arcellinida in the investigated lakes. However, studies investigating such effects of As on Arcellinida are currently lacking. More research investigating direct and indirect effects of As contamination on Arcellinida with particular emphasis on identifying different As uptake mechanisms and pathways is required to validate the use of group as a tool for inferring the dominant As species in lakes sediments. This line of research can be carried out in the form of a culturing experiment, where Arcellinida species and strains are cultured and living specimens are exposed to varying concentrations of As and other environmental controls. Observation of the response of living Arcellinida assemblages to variations of As concentrations can be then compared to those made on dead Arcellinida assemblage (i.e., results from this dissertation and Arcellinida literature) to confirm whether the identified assemblages are similar or different in their faunal composition.

The findings of Projects 3 and 4 in this dissertation provides evidence that the structure of Arcellinida assemblages may be impacted by the type of food sources available to Arcellinida communities in the sediments of As contamination-impacted lakes. For example, centropyxids are seen to thrive in substrates where microbial organisms are abundant (Project 3), 
while some difflugiids thrived in the presence of higher numbers of pennate diatoms (e.g., D. elegans; Project 4). It is, therefore, recommended to quantify the relationship between Arcellinida assemblage composition and the type of available food source to confirm whether Arcellinida assemblages in lakes near former and current gold mines are responding to variations in As contamination level, changes in the type of preferred food sources, or both. Assessment of the response of living Arcellinida species and strains in a culture experiment to exposures to varying levels of As contamination and different types of nutrients is an approach that may also address this research question. 